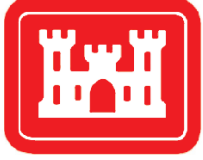

US Army Corps of Engineers ${ }_{\circledast}$

Engineer Research and

Development Center

Coastal Inlets Research Program

Sediment Transport Modeling at Stono Inlet and Adjacent Beaches, South Carolina

Honghai Li, Grace M. Maze, Kevin B. Conner, and John M. Hazelton November 2021

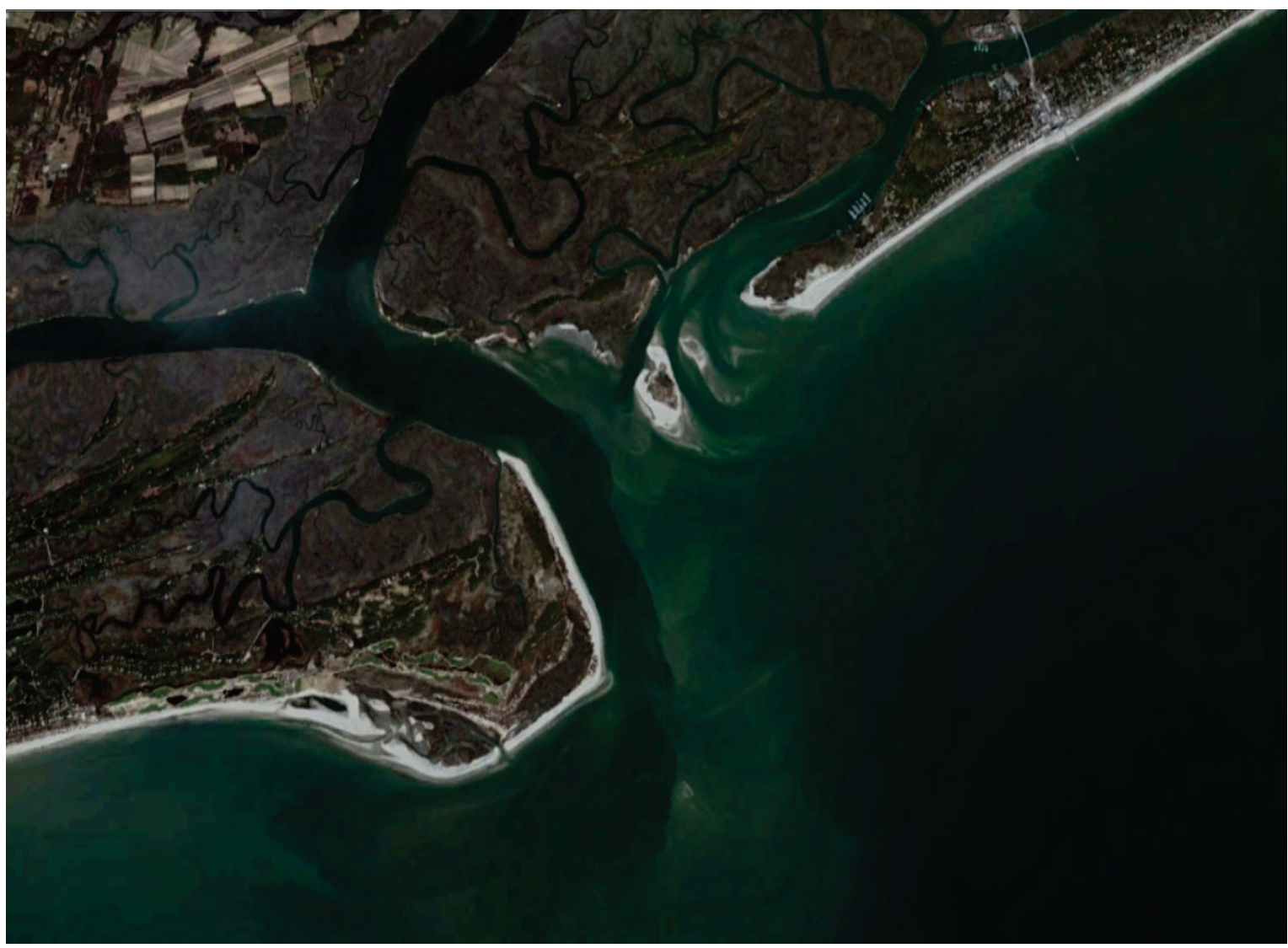


The US Army Engineer Research and Development Center (ERDC) solves the nation's toughest engineering and environmental challenges. ERDC develops innovative solutions in civil and military engineering, geospatial sciences, water resources, and environmental sciences for the Army, the Department of Defense, civilian agencies, and our nation's public good. Find out more at www.erdc.usace.army.mil.

To search for other technical reports published by ERDC, visit the ERDC online library at https://erdclibrary.on.worldcat.org/discovery. 


\section{Sediment Transport Modeling at Stono Inlet and Adjacent Beaches, South Carolina}

Honghai Li

Coastal and Hydraulics Laboratory

US Army Engineer Research and Development Center 3909 Halls Ferry Road

Vicksburg, MS 39180-6199

Grace M. Maze, Kevin B. Conner, and John M. Hazelton

US Army Corps of Engineers

Wilmington District

69 Darlington Ave

Wilmington, NC 28403

Final report

Approved for public release; distribution is unlimited.

Prepared for US Army Engineer District, Wilmington

Wilmington, NC 28403

Under MIPR W81L892470179 


\section{Abstract}

This report documents a numerical modeling investigation for dredged material from nearshore borrow areas and placed on Folly Beach adjacent to Stono Inlet, South Carolina. Historical and newly collected wave and hydrodynamic data around the inlet were assembled and analyzed. The datasets were used to calibrate and validate a coastal wave, hydrodynamic and sediment transport model, the Coastal Modeling System. Sediment transport and morphology changes within and around the immediate vicinity of the Stono Inlet estuarine system, including sand borrow areas and nearshore Folly Beach area, were evaluated. Results of model simulations show that sand removal in the borrow areas increases material backfilling, which is more significant in the nearshore than the offshore borrow areas. In the nearshore Folly Beach area, the dominant flow and sediment transport directions are from the northeast to the southwest. Net sediment gain occurs in the central and southwest sections while net sediment loss occurs in the northeast section of Folly Island. A storm and a 1-year simulation developed for the study produce a similar pattern of morphology changes, and erosion and deposition around the borrow areas and the nearshore Folly Beach area.

DISCLAIMER: The contents of this report are not to be used for advertising, publication, or promotional purposes. Citation of trade names does not constitute an official endorsement or approval of the use of such commercial products. All product names and trademarks cited are the property of their respective owners. The findings of this report are not to be construed as an official Department of the Army position unless so designated by other authorized documents. 


\section{Contents}

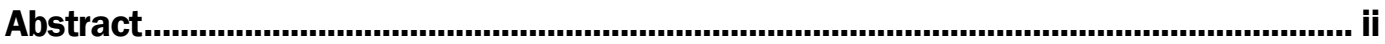

Figures and Tables......................................................................................................................

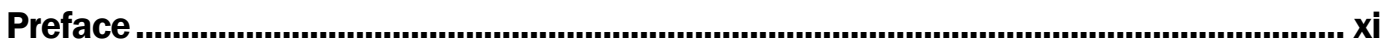

1 Introduction

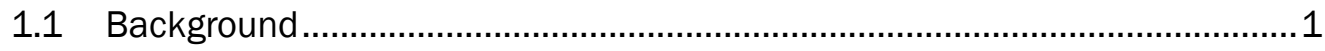

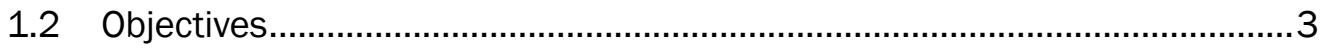

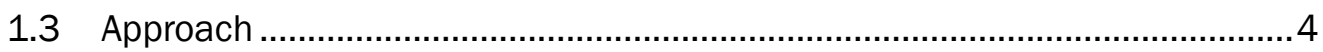

2 Data

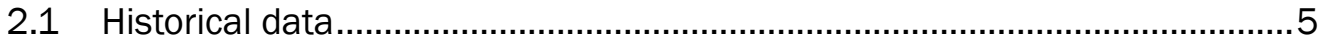

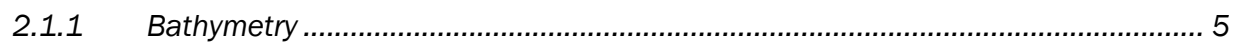

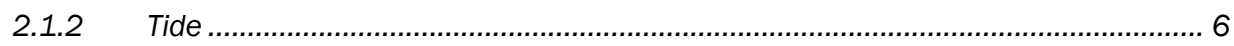

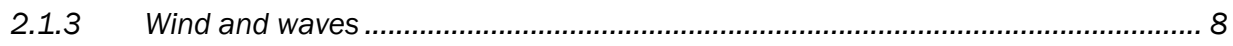

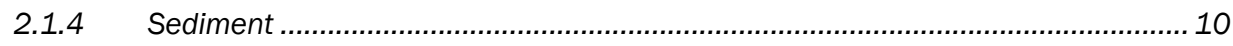

$2.2 \quad 2.2$ Field data collection.............................................................................

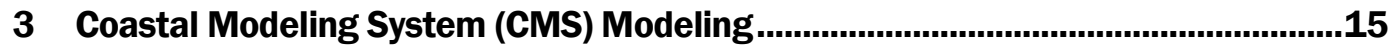

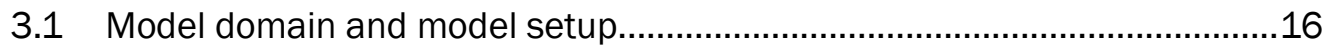

3.2 Simulation periods .............................................................................. 18

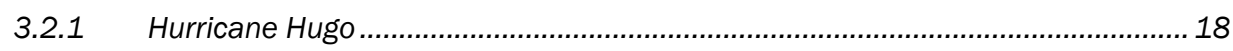

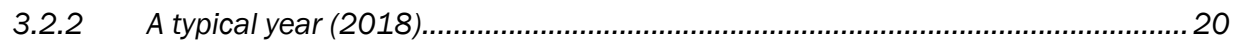

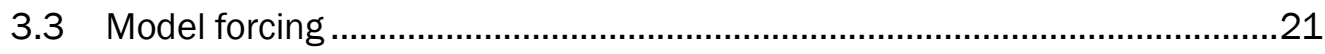

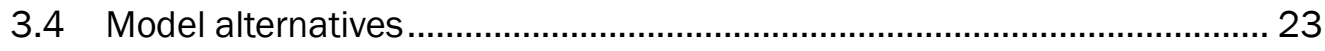

3.4.1 Borrow area: Folly River (Alternative 1) .......................................................... 26

3.4.2 Borrow area: Stono Inlet Throat (Area I, Alternative 2)..................................... 27

3.4.3 Borrow area: Stono Ebb Shoal 1 (Area J, Alternative 3) .................................... 28

3.4.4 Borrow area: Stono Ebb Shoal 2 (Area K, Alternative 4) ................................... 29

3.4.5 Borrow area: Stono Inlet (Area E, Alternative 5) ............................................... 30

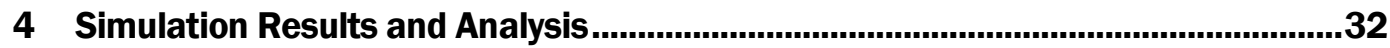

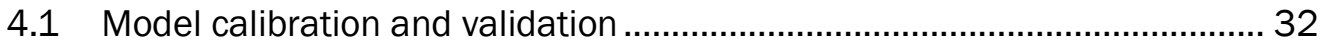

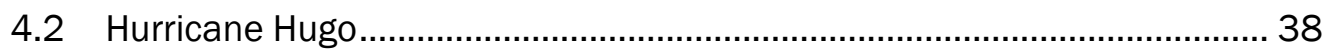

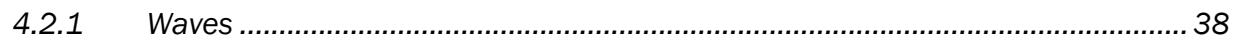

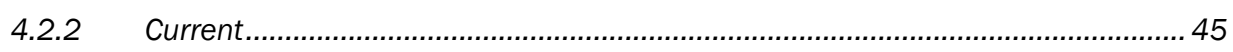

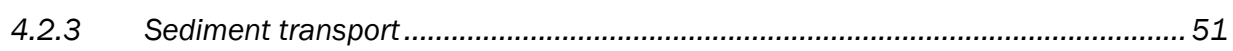

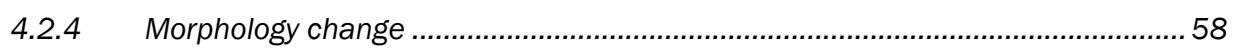

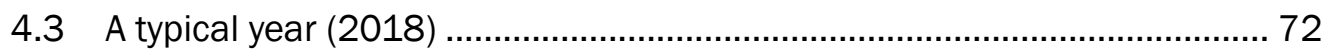

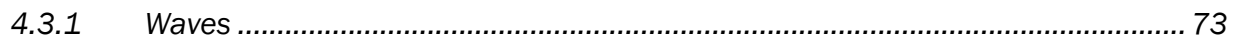

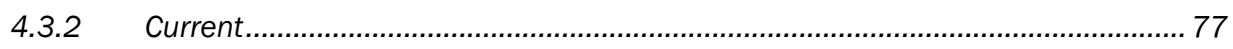

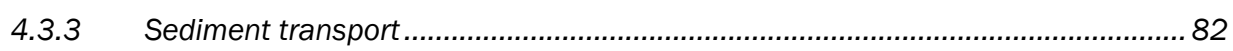

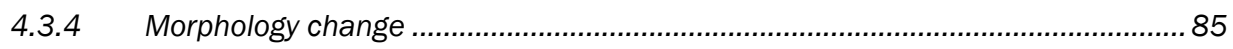




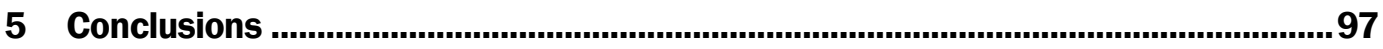

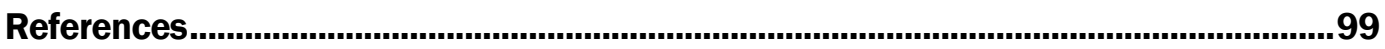

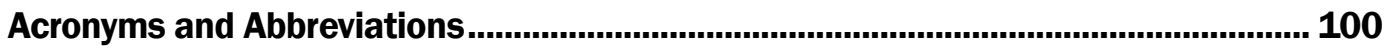

Report Documentation Page 


\section{Figures and Tables}

\section{Figures}

Figure 1-1. (a) Stono Inlet, Folly Beach, and designated sand borrow areas (Folly River; Area I = Stono Inlet Throat; Area J = Stono Ebb Shoal 1; Area K = Stono Ebb Shoal 2; Area $\mathrm{E}=$ Stono Inlet). (b) The actual dredged areas (yellow arrows) in the study

Figure 2-1. (a) NOAA DEM/CRM bathymetry and LIDAR data coverage, survey lines by USACE SAC. (b) Depth and land elevation contours of the merged dataset.

Figure 2-2. Locations of (a) NOAA tide gauge in Charleston Harbor, South Carolina (\#8665530), WIS station, NDBC buoys, and (b) two AWAC gauges deployed around Stono Inlet.

Figure 2-3. WSE measured at \#8665530 from 21 November to 30 December 2019.

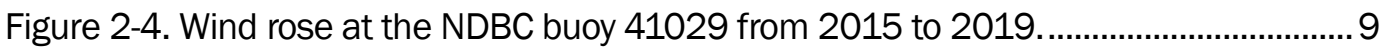

Figure 2-5. Wave rose at the NDBC buoy 41004 from 2015 to 2019 ................................10

Figure 2-6. Location of sediment grab samples.

Figure 2-7. (a) Along-channel current at AWAC\#1 and (b) longshore current at AWAC\#2 from 22 November to 25 December 2019. Positive values at AWAC\#1 are designated for the flood current and negative for the ebb current. Positive values at AWAC\#2 are designated for the ebb current (northeastward) and negative for the flood current (southwestward).

Figure 2-8. WSE at (a) AWAC\#1 and (b) AWAC\#2 from 22 November to 25 December 2019

Figure 2-9. Significant wave height, peak wave period, and mean wave direction at AWAC\#2 from 22 November to 25 December 2019.

Figure 2-10. Wind speed and direction at NDBC Buoy 41029 from 21 November to 30 December 2019.

Figure 3-1. The CMS framework.

Figure 3-2. The CMS domain. (a) Bathymetry at the inlet entrance channel and the bay, (b) CMS-Flow telescoping grid, and (c) CMS-Wave variable rectangular grid.

Figure 3-3. WSE and wind of Hurricane Hugo at NOAA gauge 8638610

(Charleston Harbor, South Carolina) and NDBC land station, FBIS1, respectively.

Figure 3-4. Wave parameters of Hurricane Hugo at WIS Station 63350..........................19

Figure 3-5. 2018 wind rose at the NDBC buoy 41029......................................................20

Figure 3-6. 2018 wave rose at the NDBC buoy 41004.....................................................21

Figure 3-7. Wind speeds and directions at NOAA Charleston Harbor tide gauge \#8665530, the NOAA coastal station FBIS1, and the NOAA offshore buoy \#41029 from 21 November to 30 December 2019.

Figure 3-8. The reach map along Folly Beach. 
Figure 3-9. Sketches of designed berms and dunes for (a) reaches 2-21, (b) reaches 22-26.

Figure 3-10. CMS bathymetry/topography along Folly Beach for (a) base case and (b) with built berm and dune.

Figure 3-11. Bathymetry of Folly River borrow area. (a) base case (before dredge);

(b) Alternative 1 (after dredge). 26

Figure 3-12. Bathymetry of Stono Inlet Throat borrow area (Area I). (a) base case (before dredge); (b) Alternative 2 (after dredge).

Figure 3-13. Bathymetry of Stono Ebb Shoal 1 borrow area (area J). (a) base case (before dredge); (b) Alternative 3 (after dredge).

Figure 3-14. Bathymetry of Stono Ebb Shoal 2 borrow area (Area K). (a) base case (before dredge); (b) Alternative 4 (after dredge).

Figure 3-15. Bathymetry of Stono Inlet borrow area (Area E). (a) base case (before dredge); (b) Alternative 5 (after dredge).

Figure 4-1. Scatter plots of the calculated and measured currents at (a) AWAC\#1 and (b) AWAC\#2 from 21 November to 25 December 2019.

Figure 4-2. Current comparisons between the measurements and the CMS calculations at (a) AWAC\#1 and (b) AWAC\#2 from 21 November to 25 December 2019)

Figure 4-3. Comparisons of WSE between the measurements and the CMS calculations at (a) AWAC\#1 and (b) AWAC\#2 from 21 November to 25 December 2019.

Figure 4-4. Comparisons of wave parameters between the measurements and the CMS calculations at AWAC\#2 from 21 November to 25 December 2019. (a) Significant wave height, (b) Peak wave period, and (c) Mean wave direction

Figure 4-5. Calculated maximum significant wave heights during the Hurricane Hugo passage on 22 September 1989 at 05:00 (GMT).

Figure 4-6. Comparison of significant wave heights between (a) base case and (b) Alternative 1 within the Folly River borrow area (the red polygon) during the Hurricane Hugo Passage on 22 September 1989 at 05:00 (GMT).

Figure 4-7. Comparison of significant wave heights between (a) base case and (b) Alternative 2 within the Stono Inlet Throat borrow area (the red polygon) during the Hurricane Hugo Passage on 22 September 1989 at 05:00 (GMT).

Figure 4-8. Comparison of significant wave heights between (a) base case and (b) Alternative 3 within the Stono Ebb Shoal 1 borrow area (the red polygon) during the Hurricane Hugo Passage on 22 September 1989 at 05:00 (GMT).

Figure 4-9. Comparison of significant wave heights between (a) base case and (b) Alternative 4 within the Stono Ebb Shoal 2 borrow area (the red polygon) during the Hurricane Hugo Passage on 22 September 1989 at 05:00 (GMT).

Figure 4-10. Comparison of significant wave heights between (a) base case and (b) Alternative 5 within the Stono Inlet borrow area (the red polygon) during the Hurricane Hugo Passage on 22 September 1989 at 05:00 (GMT).

Figure 4-11. Calculated currents during the Hurricane Hugo passage on 22

September 1989 at 03:00 (GMT). Polygons indicate the five sand borrow areas. 
Figure 4-12. Comparison of currents between (a) base case and (b) Alternative 1 within the Folly River borrow area (the polygon) during the Hurricane Hugo Passage on 22 September 1989 at 03:00 (GMT).

Figure 4-13. Comparison of currents between (a) base case and (b) Alternative 2 within the Stono Inlet Throat borrow area (the polygon in the center) during the Hurricane Hugo Passage on 22 September 1989 at 03:00 (GMT).

Figure 4-14. Comparison of currents between (a) base case and (b) Alternative 3 within the Stono Ebb Shoal 1 borrow area (the polygon in the center) during the Hurricane Hugo Passage on 22 September 1989 at 03:00 (GMT).

Figure 4-15. Comparison of currents between (a) base case and (b) Alternative 4 within the Stono Ebb Shoal 2 borrow area (the polygon in the center) during the Hurricane Hugo Passage on 22 September 1989 at 03:00 (GMT).

Figure 4-16. Comparison of currents between (a) base case and (b) Alternative 5 within the Stono Inlet borrow area (the bigger polygon in the center) during the Hurricane Hugo Passage on 22 September 1989 at 03:00 (GMT).

Figure 4-17. Calculated sediment transport rates during the Hurricane Hugo Passage on 22 September 1989 at 03:00 (GMT). Polygons indicate the five sand borrow areas.

Figure 4-18. Comparison of sediment transport rates between (a) base case and (b) Alternative 1 within the Folly River borrow area (the polygon) during the Hurricane Hugo Passage on 22 September 1989 at 03:00 (GMT).

Figure 4-19. Comparison of sediment transport rates between (a) base case and (b) Alternative 2 within the Stono Inlet Throat borrow area (the polygon in the center) during the Hurricane Hugo Passage on 22 September 1989 at 03:00 (GMT).

Figure 4-20. Comparison of sediment transport rates between (a) base case and (b) Alternative 3 within the Stono Ebb Shoal 1 borrow area (the polygon in the center) during the Hurricane Hugo Passage on 22 September 1989 at 03:00 (GMT).

Figure 4-21. Comparison of sediment transport rates between (a) base case and (b) Alternative 4 within the Stono Ebb Shoal 2 borrow area (the polygon in the center) during the Hurricane Hugo Passage on 22 September 1989 at 03:00 (GMT).

Figure 4-22. Comparison of sediment transport rates between (a) base case and (b) Alternative 5 within the Stono Inlet borrow area (the bigger polygon in the center) during the Hurricane Hugo Passage on 22 September 1989 at 03:00 (GMT).

Figure 4-23. Morphology changes for the base case in the study area from 18 to 25 September 1989. Warmer colors represent sediment accretion (delineated by red lines) and cooler colors sediment erosion (delineated by blue lines).

Figure 4-24. Morphology changes for the base case nearshore in front of Folly Beach from 18 to 25 September 1989. Warmer colors represent sediment accretion (delineated by red lines), and cooler colors sediment erosion (delineated by blue lines).

Figure 4-25. Comparison of morphology changes between (a) base case and (b) Alternative 1 within the Folly River borrow area during the Hurricane Hugo 
passage from 18 to 25 September 1989. Warmer colors represent sediment accretion and cooler colors sediment erosion.

Figure 4-26. Comparison of morphology changes between (a) base case and (b) Alternative 2 within the Stono Inlet Throat borrow area during the Hurricane Hugo passage from 18 to 25 September 1989. Warmer colors represent sediment accretion and cooler colors sediment erosion

Figure 4-27. Comparison of morphology changes between (a) base case and (b) Alternative 3 within the Stono Ebb Shoal 1 borrow area during the Hurricane Hugo passage from 18 to 25 September 1989. Warmer colors represent sediment accretion and cooler colors sediment erosion..

Figure 4-28. Comparison of morphology changes between (a) base case and (b) Alternative 4 within the Stono Ebb Shoal 2 borrow area during the Hurricane Hugo passage from 18 to 25 September 1989. Warmer colors represent sediment accretion and cooler colors sediment erosion.

Figure 4-29. Comparison of morphology changes between (a) base case and (b) Alternative 5 within the Stono Inlet borrow area during the Hurricane Hugo passage from 18 to 25 September 1989. Warmer colors represent sediment accretion and cooler colors sediment erosion

Figure 4-30. Eight polygons in the nearshore Folly Beach

Figure 4-31. The calculated total sediment transport directions across polygon lines. The positive sign indicates bed volume gain, and the negative sign indicates volume loss within the corresponding polygon area.

Figure 4-32. One polygon area surrounding Bird Key Island and three polygons on the east, southeast (SE), and south sides of Kiawah Island.

Figure 4-33. Selected locations within the five borrow areas and nearshore

Folly Beach

Figure 4-34. Comparison of significant wave heights between (a) base case and

(b) Alternative 1 at S1 within the Folly River borrow area in 2018.

Figure 4-35. Comparison of significant wave heights between (a) base case and

(b) Alternative 2 at S2 within the Stono Inlet Throat borrow area in 2018.

Figure 4-36. Comparison of significant wave heights between (a) base case and

(b) Alternative 3 at S3 within the Stono Ebb Shoal 1 borrow area in 2018.

Figure 4-37. Comparison of significant wave heights between (a) base case and

(b) Alternative 4 at S4 within the Stono Ebb Shoal 2 borrow area in 2018.

Figure 4-38. Comparison of significant wave heights between (a) base case and

(b) Alternative 5 at S5 within the Stono Inlet borrow area in 2018.

Figure 4-39. Comparison of significant wave heights between (a) base case and

(b) Alternative 1 at S6 in the nearshore Folly Beach area in 2018.

Figure 4-40. Calculated depth-averaged (a) flood and (b) ebb currents on 27

February 2018 at 22:00 and 28 February 2018 at 04:00 GMT, respectively.

Figure 4-41. Comparison of current speeds between (a) base case and (b)

Alternative 1 at S1 within the Folly River borrow area in 2018.

Figure 4-42. Comparison of current speeds between (a) base case and (b)

Alternative 2 at S2 within the Stono Inlet Throat borrow area in 2018.

Figure 4-43. Comparison of current speeds between (a) base case and

(b) Alternative 3 at S3 within the Stono Ebb Shoal 1 borrow area in 2018. 
Figure 4-44 Comparison .of current speeds between (a) base case and (b)

Alternative 4 at S4 within the Stono Ebb Shoal 2 borrow area in 2018.

Figure 4-45. Comparison of current speeds between (a) base case and

(b) Alternative 5 at S5 within the Stono Inlet borrow area in 2018.

Figure 4-46 Comparison of current speeds between (a) base case and (b)

Alternative 1 at S6 within the nearshore Folly Beach area in 2018.

Figure 4-47. Comparison of sediment transport rates between (a) base case and

(b) Alternative 1 at S1 within the Folly River borrow area in 2018.

Figure 4-48. Comparison of sediment transport rates between (a) base case and

(b) Alternative 2 at S2 within the Stono Inlet Throat borrow area in 2018.

Figure 4-49. Comparison of sediment transport rates between (a) base case and

(b) Alternative 3 at S3 within the Stono Ebb Shoal 1 borrow area in 2018.

Figure 4-50. Comparison of sediment transport rates between (a) base case and

(b) Alternative 4 at S4 within the Stono Ebb Shoal 2 borrow area in 2018.

Figure 4-51. Comparison of sediment transport rates between (a) base case and

(b) Alternative 5 at S5 within the Stono Inlet borrow area in 2018.

Figure 4-52. Comparison of sediment transport rates between (a) base case and

(b) Alternative 1 at S6 in the nearshore Folly Beach area in 2018.

Figure 4-53. Comparison of morphology changes between (a) base case and

(b) Alternative 1 within the Folly River borrow area in 2018. Warmer colors represent sediment accretion and cooler colors sediment erosion.

Figure 4-54. Comparison of morphology changes between (a) base case and

(b) Alternative 2 within the Stono Inlet Throat borrow area in 2018. Warmer

colors represent sediment accretion and cooler colors sediment erosion.

Figure 4-55. Comparison of morphology changes between (a) base case and

(b) Alternative 3 within the Stono Ebb Shoal 1 borrow area in 2018. Warmer

colors represent sediment accretion and cooler colors sediment erosion.

Figure 4-56. Comparison of morphology changes between (a) base case and (b) Alternative 4 within the Stono Ebb Shoal 2 borrow area in 2018. Warmer colors represent sediment accretion and cooler colors sediment erosion.

Figure 4-57. Comparison of morphology changes between (a) base case and

(b) Alternative 5 within the Stono Inlet borrow area in 2018. Warmer colors

represent sediment accretion and cooler colors sediment erosion.

Figure 4-58. Morphology changes for the base case nearshore in front of Folly Beach in 2018. Warmer colors represent sediment accretion (delineated by red lines) and cooler colors sediment erosion (delineated by blue lines).

Figure 4-59. The calculated total sediment transport directions across polygon lines. The positive sign indicates bed volume gain and the negative the volume loss within the corresponding polygon area.

\section{Tables}

Table 3-1. Physical scales of the five borrow areas (Figure 1-1)

Table 4-1. Goodness of fit statistics between the AWAC\#1 measurements and the CMS calculations from 21 November to 25 December 2019.

Table 4-2. Goodness of fit statistics between the AWAC\#2 measurements and the CMS calculations from 21 November to 25 December 2019. 
Table 4-3. Comparisons of significant wave heights between the base case (before sand dredge) and alternatives (after sand dredge) in borrow areas during Hurricane Hugo.

Table 4-4. Comparisons of currents between the base case (before sand dredge) and alternatives (after sand dredge) in borrow areas during Hurricane Hugo.

Table 4-5. Comparisons of sediment transport rates between the base case (before sand dredge) and alternatives (after sand dredge) in borrow areas during Hurricane Hugo.

Table 4-6. Longshore erosion and deposition zones in front of Folly Beach during the passage of Hurricane Hugo in September 1989. Positive depths are the land elevation above MSL.

Table 4-7. Comparisons of depth changes between the base case (before sand dredge) and alternatives (after sand dredge) in borrow areas during Hurricane Hugo.

Table 4-8. Comparisons of bed volume changes (cubic yard) between the base case (before sand dredge) and alternatives (after sand dredge) in designated and actual borrow areas during Hurricane Hugo. The negative sign indicates the volume loss and the positive the volume gain

Table 4-9. Bed volume changes (cubic yard) for the base case (before sand dredge) and alternatives (after sand dredge) in polygon areas as shown in Figure 4-30 during Hurricane Hugo. The negative sign indicates the volume loss, and the positive sign indicates the volume gain.

Table 4-10. Bed volume changes (cubic yard) for the base case (before sand dredge) and alternatives 1, 2, and 3 (after sand dredge) in polygon areas around Bird Key Island and Kiawah Island during the passage of Hurricane Hugo in September 1989. The negative sign indicates the volume loss and the positive sign indicates the volume gain.

Table 4-11. Annual averaged wave heights, current speeds, and sediment transport rates for the base and the alternative cases in the borrow areas and the nearshore Folly Beach area.

Table 4-12. Comparisons of depth changes between the base case (before sand dredge) and alternatives (after sand dredge) in borrow areas in 2018.

Table 4-13. Longshore erosion and deposition zones in front of Folly Beach during 2018. Positive depths are the land elevation above MSL.

Table 4-14. Comparisons of bed volume changes (cubic yard) between the base case (before sand dredge) and alternatives (after sand dredge) in designated and actual borrow areas in 2018. The negative sign indicates the volume loss and the positive the volume gain.

Table 4-15. Bed volume changes (cubic yard) for the base case (before sand dredge) and alternatives (after sand dredge) in polygon areas as shown in Figure 4-30 in 2018. The negative sign indicates the volume loss and the positive the volume gain.

Table 4-16. Bed volume changes (cubic yard) for the base case (before sand dredge) and alternatives 1, 2, and 3 (after sand dredge) in polygon areas around Bird Key Island and Kiawah Island in 2018. The negative sign indicates the volume loss and the positive the volume gain 


\section{Preface}

This study was conducted for the US Army Engineer District, Wilmington (SAW), by the Coastal and Hydraulics Laboratory (CHL) of the US Army Engineer Research and Development Center (ERDC), funding provided by SAW under MIPR W81L892470179.

The field data collection program was completed by Coastal Engineering Branch of CHL.

The Coastal Inlets Research Program (CIRP) performed the study. The CIRP is administered for Headquarters, US Army Corps of Engineers (HQUSACE), by the ERDC CHL, Vicksburg, MS, under the Navigation Program of HQUSACE. Ms. Tiffany Burroughs is HQUSACE Navigation Business Line Manager. Mr. Charles E. Wiggins, CHL, is the ERDC Technical Director for Navigation. Dr. Tanya M. Beck, CHL, is the CIRP Program Manager.

This work was conducted under the general administrative supervision of Ms. Lauren M. Dunkin, Chief of Coastal Engineering Branch, and Ms. Ashley Frey, Chief of the Navigation Division. Mr. Keith Flowers and Dr. Ty V. Wamsley were the Deputy Director and Director of CHL during this study period, respectively.

At the time of publication of this report, COL Teresa A. Schlosser was Commander of ERDC, and Dr. David W. Pittman was ERDC Director. 


\section{Introduction}

\subsection{Background}

Stono Inlet lies approximately $10 \mathrm{mi}^{1}(16.1 \mathrm{~km})$ southwest of the Charleston Harbor, South Carolina. Folly Beach is located on Folly Island, which is approximately $6 \mathrm{mi}(9.7 \mathrm{~km})$ long and has a maximum width of $2,800 \mathrm{ft}$ $(853 \mathrm{~m})$ near the center and narrows to under $200 \mathrm{ft}(61 \mathrm{~m})$ wide on the northeast end. Folly Island is bounded by Lighthouse Inlet on the northeast and by Stono Inlet to the southwest. The tidally influenced Folly River is located behind the southwest end of the island. The Folly River Navigation Channel is a shallow-draft channel. The dredged channel stretches out from downstream of the river to Stono Inlet and further extends to the open ocean through inlet ebb shoals. Kiawah Island is on the southwest side of Stono Inlet, and Stono River enters the inlet from the north (Figure 1-1).

\footnotetext{
1 For a full list of the spelled-out forms of the units of measure used in this document, please refer to US Government Publishing Office Style Manual, 31st ed. (Washington, DC: US Government Publishing Office 2016), 248-52, https://www.govinfo.gov/content/pkg/GPO-STYLEMANUAL-2016/pdf/GPOSTYLEMANUAL-2016.pdf.
} 
Figure 1-1. (a) Stono Inlet, Folly Beach, and designated sand borrow areas (Folly River; Area I = Stono Inlet Throat; Area J = Stono Ebb Shoal 1; Area K = Stono Ebb Shoal 2; Area $\mathrm{E}=$ Stono Inlet). (b) The actual dredged areas (yellow arrows) in the study.
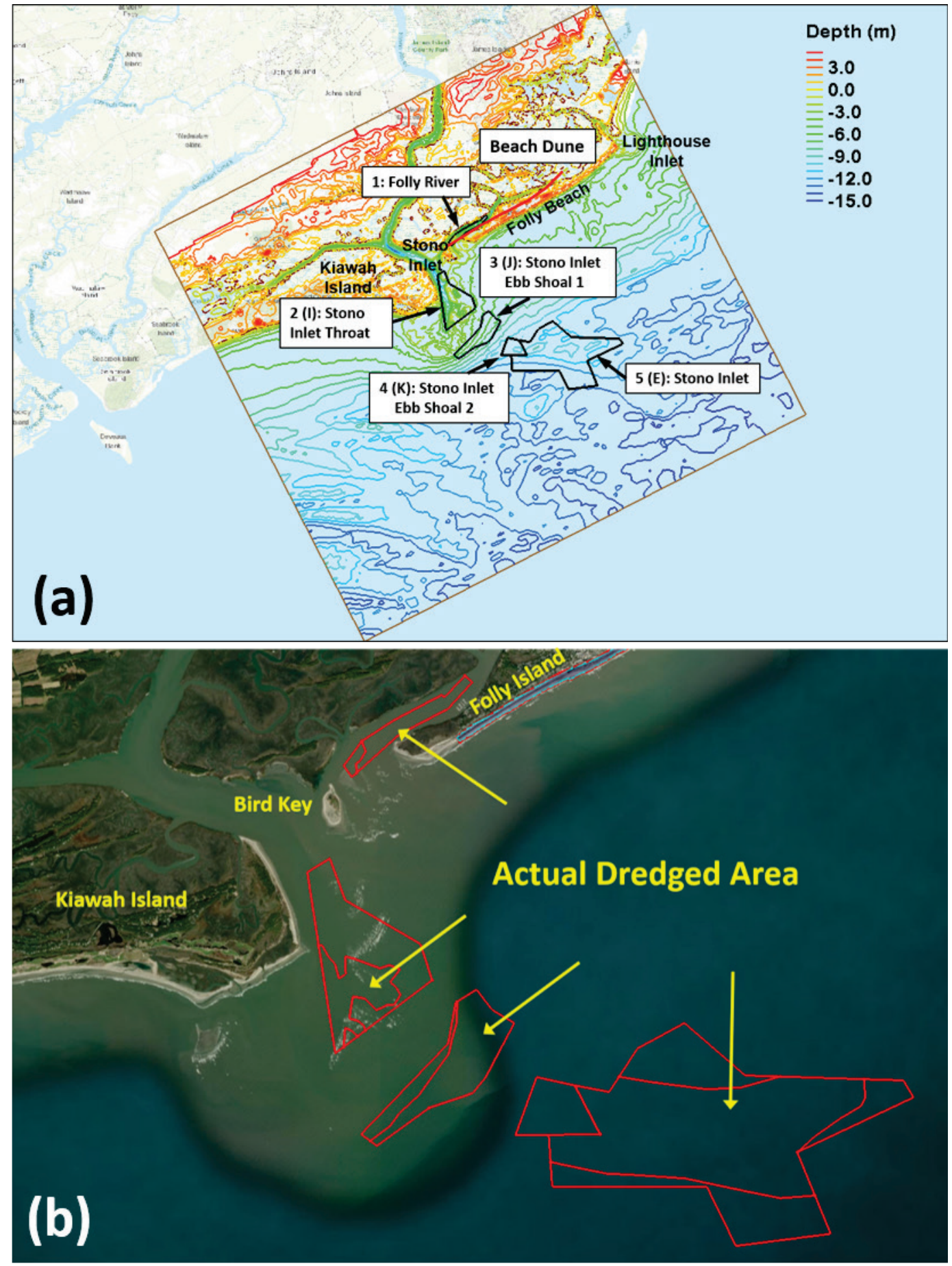
Elevations on the island range from a low of $5 \mathrm{ft}(1.5 \mathrm{~m})$ to over $14 \mathrm{ft}(4.3 \mathrm{~m})$ NAVD88 along a remnant dune system that runs intermittently along the center of the island. The entire length of Folly Beach is experiencing shoreline recession with higher rates at the ends of the island and lower rates along the middle. The predominant longshore drift is toward the southwest. The mean grain diameter of the native beach is $0.17 \mathrm{~mm}$. There are multiple groin fields along Folly Beach of varying effectiveness. In June 2013, a $745 \mathrm{ft}(227 \mathrm{~m})$ long steel sheet pile groin with armor stone toe protection was constructed on the southwest end of the island. The Folly Beach shoreline is protected by numerous concrete and timber sheet pile bulkheads, stone revetments, concrete rubble revetments, and bulkheads with armor stone at the base. The structures are of various length, elevation, design, age, and construction quality.

The US Army Corps of Engineers (USACE), Wilmington District, is evaluating continued federal interest of Folly Beach, SC, coastal storm risk management project. The project extends $28,890 \mathrm{ft}(8,806 \mathrm{~m})$ along beachfront of the City of Folly Beach. The past borrow sources for the nourishment project include offshore areas and the Folly River. The Folly River navigation channel has routinely been dredged since the 1970s. The first large-scale dredging of Folly River was in 1993 with 3.1 mcy (2.4 million $\mathrm{m}^{3}$ ) removed from the river and $2.7 \mathrm{mcy}$ ( 2.1 million $\mathrm{m}^{3}$ ) placed along Folly Beach. The most recent project placed 1.2 mcy (o.9 million m3) in 2018 with material from the Folly River.

\subsection{Objectives}

Dredge and placement activities significantly modify nearshore bathymetry and lead to sediment movement and redistribution. To assess the impact of borrow area selection on local morphologic changes and understand nearshore sediment transport in the area, the selection and design of borrow areas must be carefully examined for suitable sand material surrounding the littoral system. At the same time, beach nourishment projects need to be carried out to mitigate shoreline erosion. The purpose of the study is to evaluate the transport and morphologic changes for sediment material dredged from five borrow source areas as shown in Figure 1-1 and placed on Folly Beach adjacent to Stono Inlet. 


\subsection{Approach}

A coastal numerical model is applied to calculate waves, current, tide, sediment transport, and morphology change, and to perform sediment budget analysis within and around the immediate vicinity of Stono Inlet, Bird Key, Folly Island, and the eastern end of Kiawah Island. Sediment management alternatives on sand dredge and placement are developed, the effect of major forcing conditions (hydrodynamics, waves, and wind) on sediment movement is determined, and the impact of dredge/placement activities on sediment balance is investigated around Stono Inlet, the Folly River Navigation Channel, and Folly Beach.

This report is organized as follows. Chapter 2 introduces historical data that were applied to configure the numerical model and drive the numerical simulations, and the field data collection effort. Chapter 3 describes the methods for the numerical study. Chapter 4 presents the results of numerical modeling including the calibration and validation of the calculated waves and hydrodynamics to the field measurements. Chapter 5 summarizes the results of the study and provides conclusions regarding sediment transport around material borrow areas adjacent to the Stono Inlet estuarine system. 


\section{Data}

A variety of physical and environmental data for the Stono Inlet study area were assembled and analyzed in the present study. Historical data available include open ocean, inlet channel and estuarine bathymetry, tidal variations, coastal wind and waves, and sediment composition.

\subsection{Historical data}

\subsubsection{Bathymetry}

Bathymetric data were compiled from a combination of ocean, beach, river surveys, and LIDAR data using Surface-water Modeling System (SMS 13.0) (Aquaveo 2020). Where merged datasets overlapped coverage, priority was given to the newest dataset. Folly River, Folly Beach, and channel surveys were conducted in spring and fall 2017, fall 2018, and spring 2019 separately. These surveys were collected as a part of the ongoing navigation projects from the USACE Charleston District (SAC). The other areas within the model domain were covered by the 1/9 arc-second Coastal Digital Elevation Model (DEM) dataset and the 3 arc-second Coastal Relief Model (CRM) dataset developed at the National Oceanic and Atmospheric Administration (NOAA) National Centers for Environmental Information (NOAA NCEI 2020). Shoreline data were used from the NOAA Continually Updates Shoreline Product (NOAA NGS 2011) and Google Earth images.

Figure 2-1 shows the spatial coverages and the depth (land elevation) contours of the merged datasets in the study area. Around Stono Inlet entrance channel and the material borrow areas, the latest conditional survey data were used to update areas of overlap with DEM/CRM data. The LIDAR surveys, DEM, and CRM datasets have more thorough coverage of land, coastal, and offshore areas with a high spatial resolution. Because of its uniform and dense data distribution, only the extent of the spatial coverage is shown in Figure 2-1(a). Using the datum information of NOAA tide gage \#8665530 at Charleston, SC (NOAA 2020) all datasets were converted to local Mean Sea Level (MSL) and incorporated in numerical wave and flow models. 
Figure 2-1. (a) NOAA DEM/CRM bathymetry and LIDAR data coverage, survey lines by USACE SAC. (b) Depth and land elevation contours of the merged dataset.

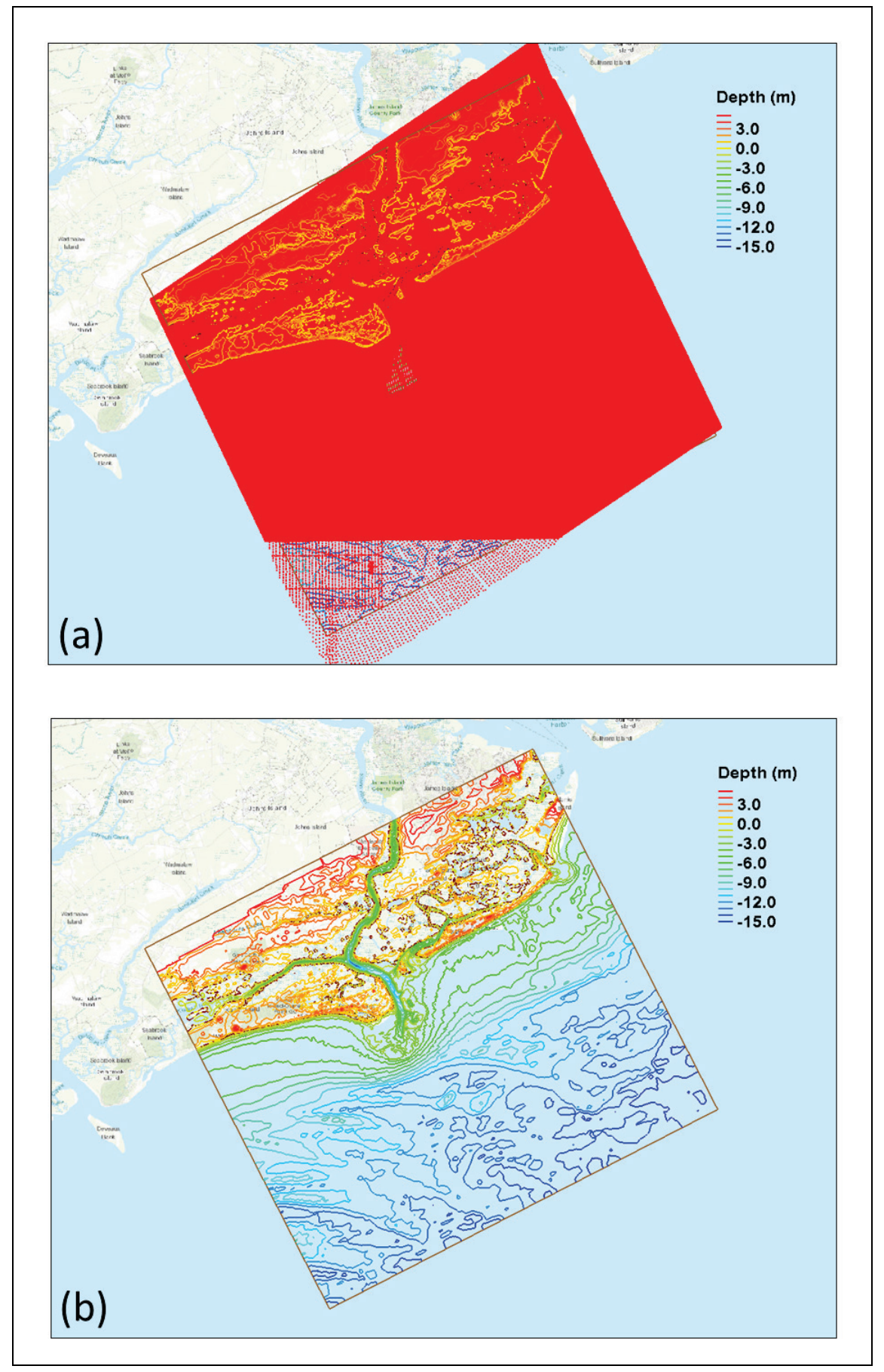

\subsubsection{Tide}

Water surface elevation (WSE) data were downloaded from NOAA Charleston tide gage \#8665530 (NOAA 2020). Figure 2-2 shows the location of the gage. A record of WSEs from 21 November to 31 December 
2019 is plotted in Figure 2-3, which indicates distinguished spring and neap tidal ranges, and a mixed, predominantly semi-diurnal tidal regime. The mean tidal range (mean high water - mean low water) is $1.59 \mathrm{~m}$ $(5.22 \mathrm{ft}$ ), and the maximum tidal range (mean higher high water - mean lower low water $)$ is $1.76 \mathrm{~m}(5.77 \mathrm{ft})$.

Figure 2-2. Locations of (a) NOAA tide gauge in Charleston Harbor, South Carolina (\#8665530), WIS station, NDBC ${ }^{1}$ buoys, and (b) two AWAC ${ }^{2}$ gauges deployed around Stono Inlet.

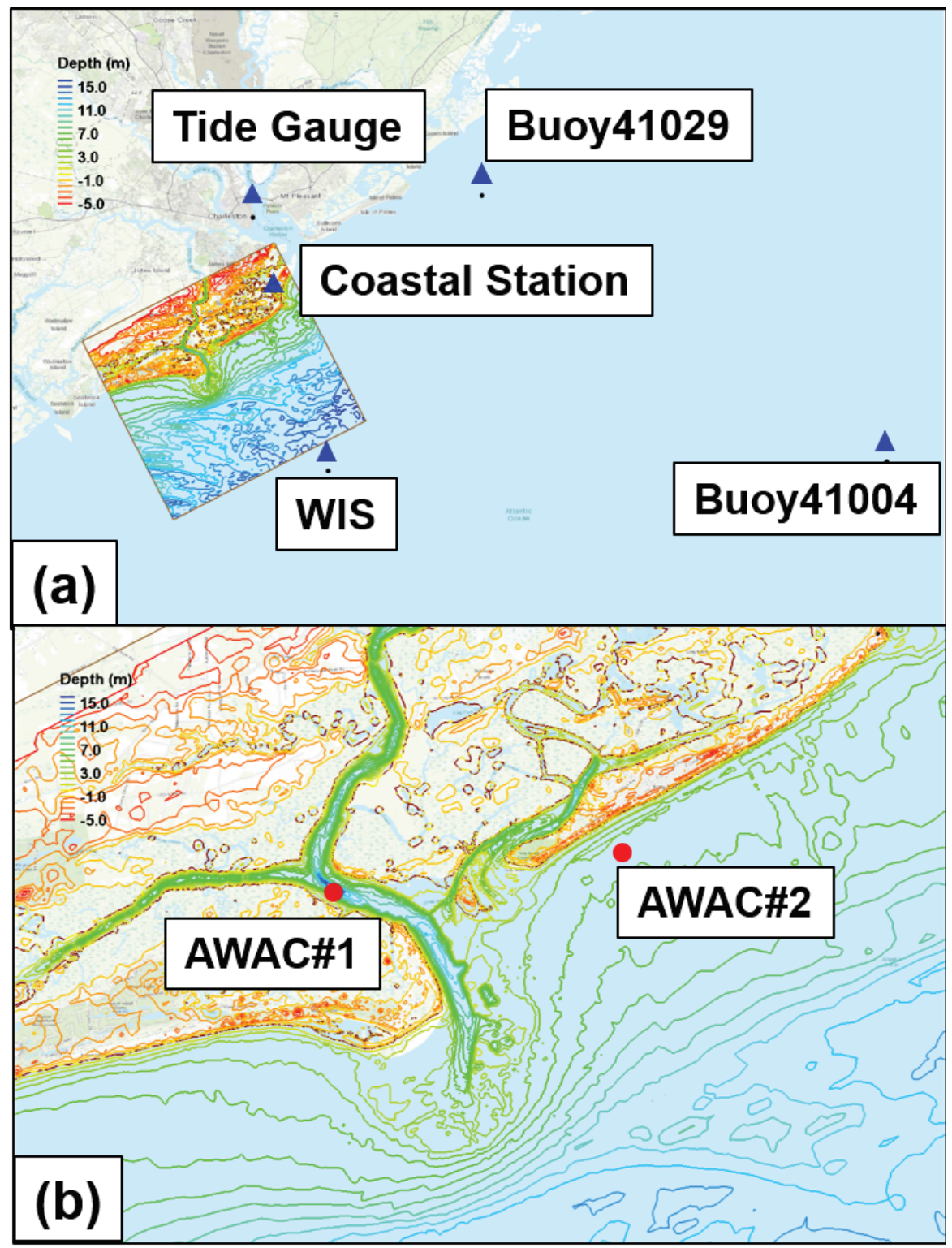

1 National Data Buoy Center

2 Acoustic wave and current profiler 
Figure 2-3. WSE measured at \#8665530 from 21 November to 30 December 2019.

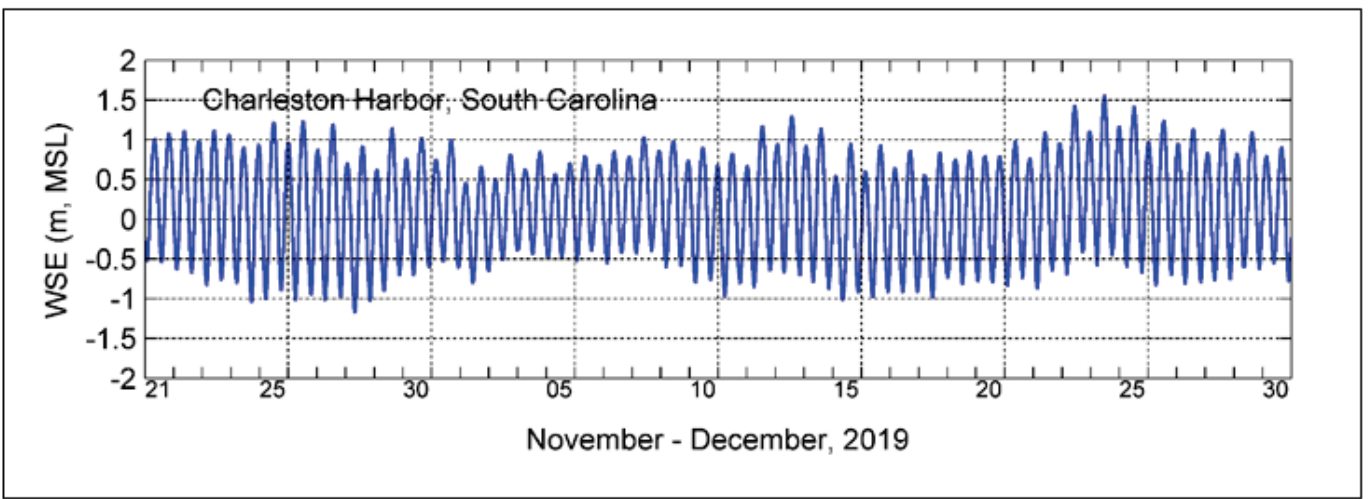

\subsubsection{Wind and waves}

Wind data were obtained from an NDBC (NDBC 2020) land station, Station FBIS1, and a nearshore buoy, Buoy 41029, for different simulation periods. Station FBIS1 is located on the northern side of Folly Island and Buoy 41029 approximately $40 \mathrm{~km}$ northeast of Stono Inlet (Figure 2-2). Figure 2-4 shows a wind rose at Buoy 41029 using the data from 2015 to 2019. The $5 \mathrm{yr}$ dataset indicates two dominant shore-parallel wind directions, southwesterly and northeasterly, in the region. Southwesterly wind occurred close to $37 \%$ of the time while northeasterly wind occurred approximately $30 \%$ of the time. On average, the northeasterly wind had a stronger speed. When wind blew from the northeast direction, approximately $10 \%$ of time the wind speed reached $10 \mathrm{~m} / \mathrm{s}$ and above. The $5 \mathrm{yr}$ mean wind speed is approximately $5.7 \mathrm{~m} / \mathrm{s}(18.7 \mathrm{ft} / \mathrm{s})$. 
Figure 2-4. Wind rose at the NDBC buoy 41029 from 2015 to 2019.

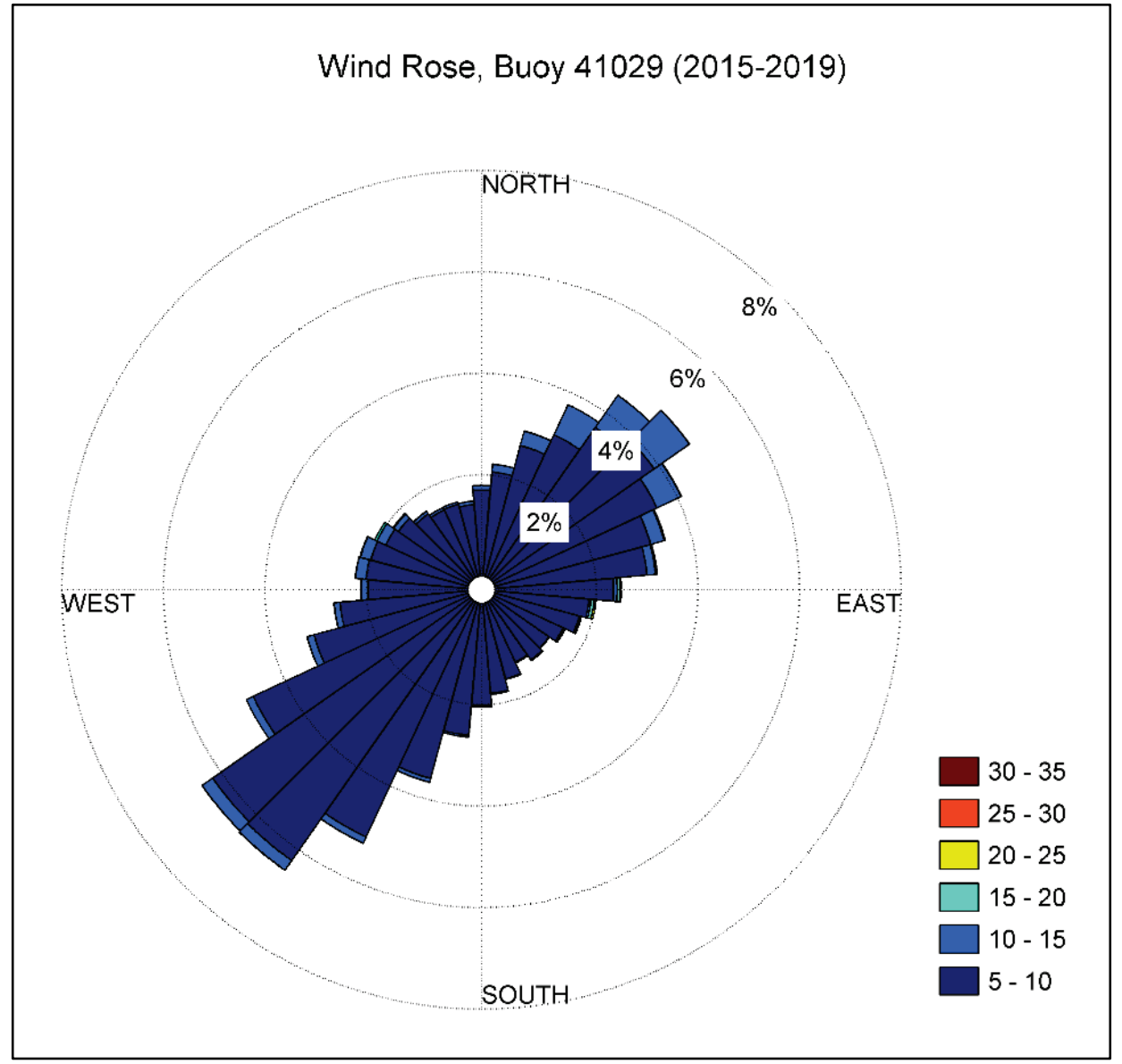

Wave data were downloaded from an NDBC offshore buoy 41004, located approximately $85 \mathrm{~km}$ (62.8 mi) east of Stono Inlet. When no wave data were available, USACE hindcast wave field climatologies, Wave Information Studies (WIS) were used (http://wis.usace.army.mil/, accessed 5 October 2020). WIS Station 63350 is the closest nearshore station to Stono Inlet $(20 \mathrm{~km}$ [12.4 mi]) (Figure 2-2) and provides wave parameters (wave height, wave period, and wave direction) for this modeling study. Figure 2-5 shows a wave rose at Buoy 41004 for the data from 2015 to 2019, which indicates that more than $50 \%$ of the time, waves propagate from the southeast sector, close to the shore normal direction. The secondary dominant wave direction is southwest, approximately parallel to shoreline, which occurs close to $20 \%$ of the time. The region experiences a mild wave conditions year round, and only approximately $11 \%$ of the time, significant wave heights are above $2 \mathrm{~m}$ $(6.56 \mathrm{ft})$, propagating from the two dominant directions. The $5 \mathrm{yr}$ mean significant wave height is approximately $1.3 \mathrm{~m}(4.27 \mathrm{ft})$, and the peak wave height is between 5 and $6 \mathrm{~m}$ ( 16.41 and $19.69 \mathrm{ft}$ ), usually corresponding to tropical or extratropical storms. 
Figure 2-5. Wave rose at the NDBC buoy 41004 from 2015 to 2019.

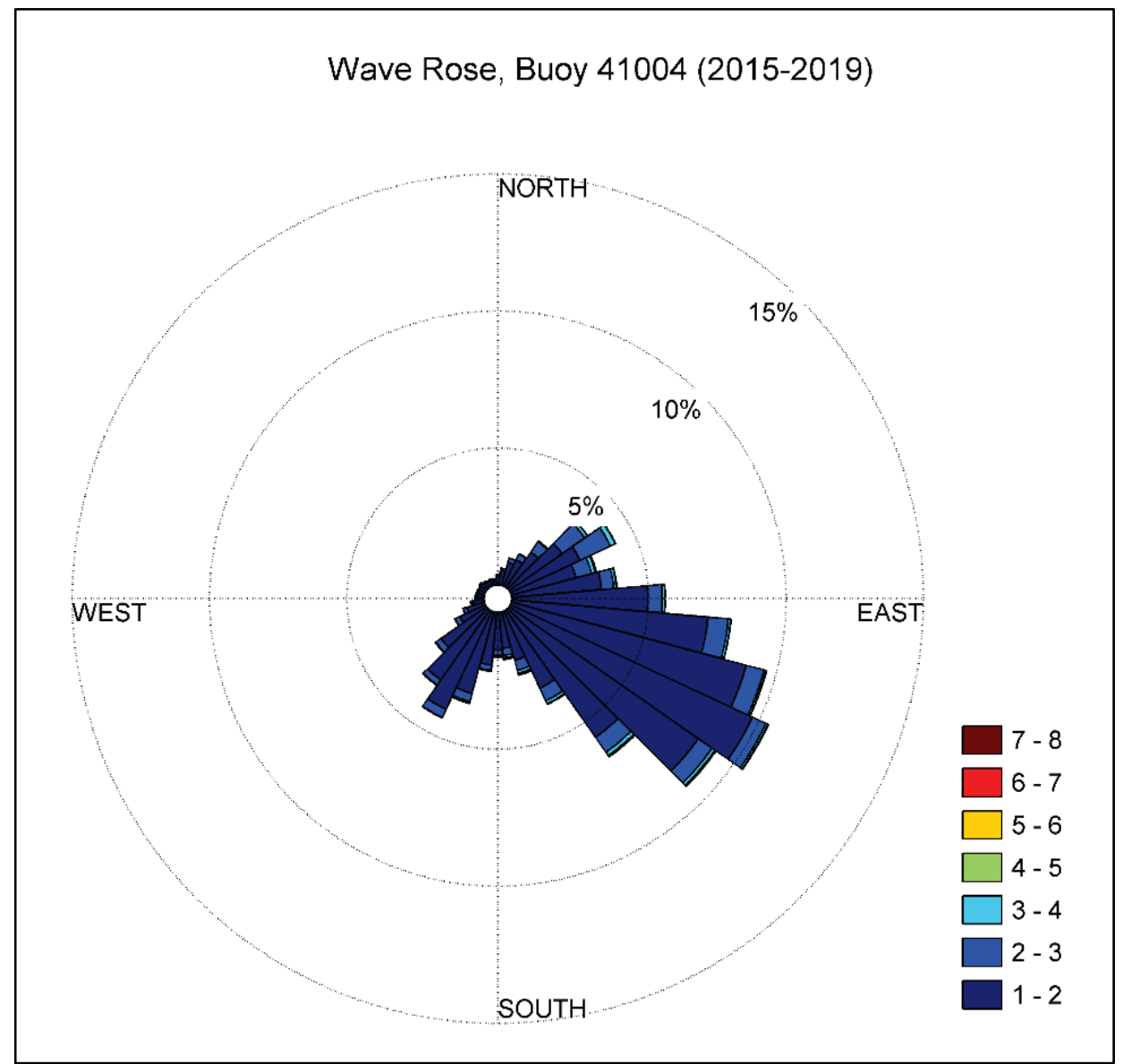

Figure 2-4 and Figure 2-5 show that the study area is characterized by a high-energy wave climate and experiences energetic wave conditions during the passages of extra-tropical storms in the winter. Because of the pattern changes in monthly mean waves and wind, the sediment transport pattern in this region is also expected to change during the study period from September 2015 to March 2016.

\subsubsection{Sediment}

Sediment data were compiled from vibracore samples taken from 20022015 within Folly River, Stono Inlet, and offshore potential borrow areas. Grab samples from Folly Beach were collected in 1994 and 1998. Mean grain size, D50, was available at sample locations as shown in Figure 2-6. In the nearshore areas around the inlet and the material borrow sites, the average D50 is $0.17 \mathrm{~mm}$, and in the offshore area the average D50 value is $0.25 \mathrm{~mm}$. 
Figure 2-6. Location of sediment grab samples.

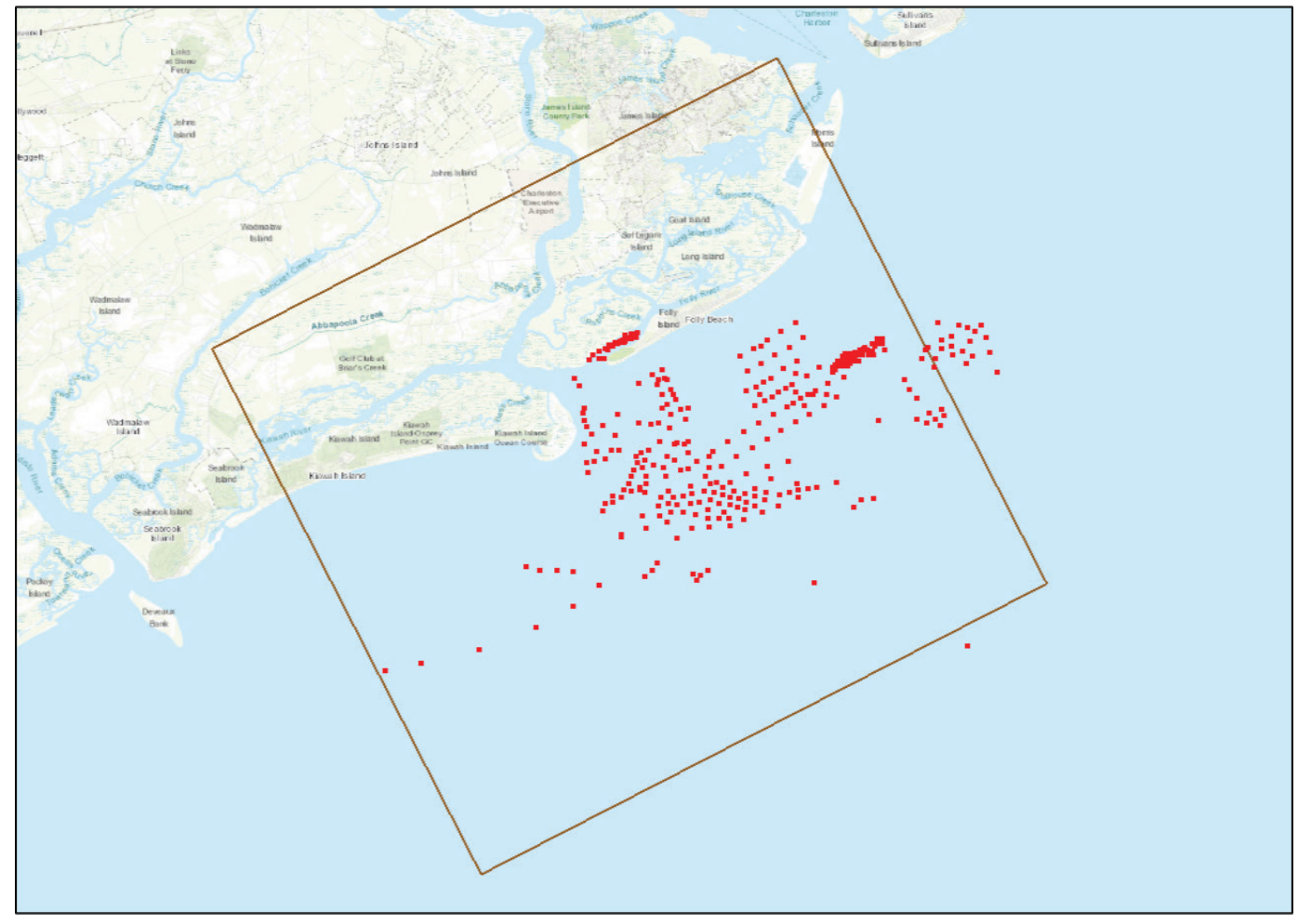

\section{$2.2 \quad 2.2 \quad$ Field data collection}

For this numerical modeling study, two upward-looking AWACs were deployed. AWAC\#1 was located in the Stono River, off the deepest part of the river channel at a water depth of $9.1 \mathrm{~m}(29.86 \mathrm{ft})$, and AWAC\#2 was close to Folly Beach in the nearshore open area at a water depth of $5.1 \mathrm{~m}$ (16.73 ft) (Figure 2-2). The deployment was originally planned for 1 month but lasted over 4 months starting on 22 November 2019 and ending on 11 April 2020. Severe weather conditions and instrument burials resulted in the unexpected delayed recovery of the AWACs.

Waves, current, and WSE were measured at each AWAC location. It was noted that the acoustic transceivers had been buried repeatedly after 27 December 2019. The AWAC data measured between 22 November and 25 December 2019 were analyzed and used for model calibration and validation.

AWAC\#1 was located in the river channel, and the along-channel current component was much greater than the cross-channel component. AWAC\# 2 sat in the open ocean area nearshore and received strong wave impact. Therefore, the longshore current was much greater than the 
cross-shore current. Figure 2-7 shows the along-channel and the longshore current measured at AWAC\#1 and AWAC\#2, respectively. The current variations in Figure 2-7a illustrate that the along-channel current at AWAC\# 1 ranges from $-1.0 \mathrm{~m} / \mathrm{s}(-3.28 \mathrm{ft} / \mathrm{s}$ ) (ebb current) to $+0.7 \mathrm{~m} / \mathrm{s}$ $(+2.3 \mathrm{ft} / \mathrm{s})$ (flood current), and the averaged current speed is $-0.1 \mathrm{~m} / \mathrm{s}$ $(-0.33 \mathrm{ft} / \mathrm{s})$, indicating an ebb-dominated estuary. Figure 2-7b displays a low-frequency variation of longshore current at AWAC\#2. Overlapping the low-frequency signal is the tidal signal. Clearly, the tidal current at AWAC\# 2 is much weaker compared with that at AWAC\#1, and tidal amplitude has a range of $0.2-0.4 \mathrm{~m}(0.66-1.31 \mathrm{ft})$.

Figure 2-7. (a) Along-channel current at AWAC\#1 and (b) longshore current at AWAC\#2 from 22 November to 25 December 2019. Positive values at AWAC\#1 are designated for the flood current and negative for the ebb current. Positive values at AWAC\#2 are designated for the ebb current (northeastward) and negative for the flood current (southwestward).

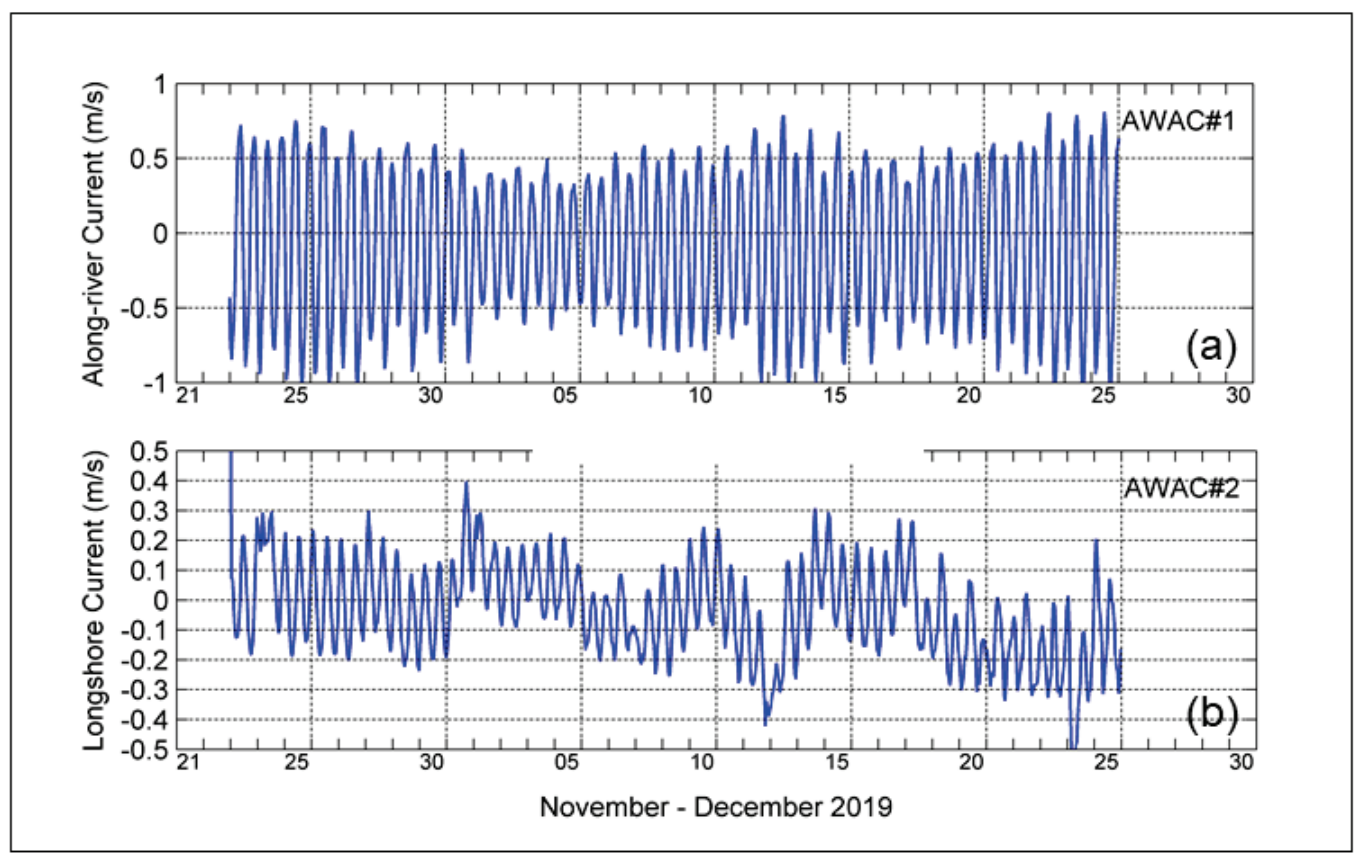

Figure 2-8 shows WSEs at AWAC\#1 and AWAC\#2 from 21 November to 25 December 2019. Both survey sites display similar tidal fluctuations, varying from -1.2 to $1.4 \mathrm{~m}(-3.94$ to $4.59 \mathrm{ft})$. Examining the values at AWAC sites and NOAA Charleston Harbor site (Figure 2-3), the WSE observed around Stono Inlet corresponds to the measurements at the NOAA Charleston gage. The primary difference is that the tidal phase at Stono Inlet is leading that at Charleston Harbor by approximately $45-50$ min. 
Figure 2-8. WSE at (a) AWAC\#1 and (b) AWAC\#2 from 22 November to 25 December 2019.

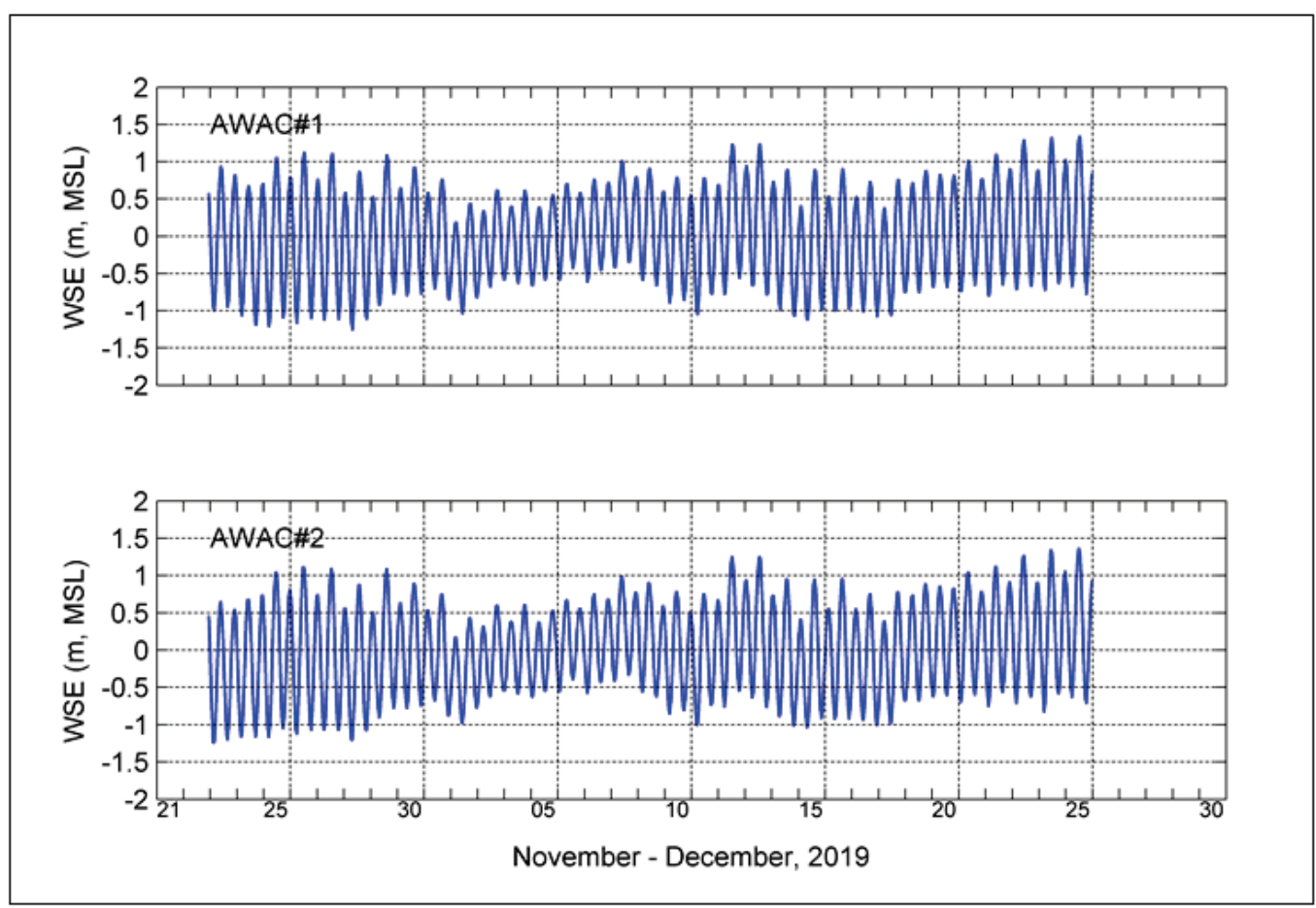

The measured wave parameters (significant wave height, peak wave period, and mean wave direction) at AWAC\#2 are shown in Figure 2-9 for the late fall and early winter period. Corresponding wind speed and direction observed at NDBC Buoy 41029 are shown in Figure 2-10. The mean significant wave height was $0.7 \mathrm{~m}(2.3 \mathrm{ft})$, and the mean wave period was $8.2 \mathrm{~s}$ during the period. A few weather events with a wind speed greater than $10 \mathrm{~m} / \mathrm{s}(32.81 \mathrm{ft} / \mathrm{s})$ caused relatively large waves, and the maximum wave height greater than $2 \mathrm{~m}(6.56 \mathrm{ft})$ occurred on 23 December 2019. The weather events were primarily related to winter storms with wind blowing from the north-northeast direction. Nearshore waves measured at AWAC\#2 primarily propagated from the south-southeast direction approximately normal to the shoreline, which was due to wave refraction when approaching shallow coastal area. 
Figure 2-9. Significant wave height, peak wave period, and mean wave direction at AWAC\#2 from 22 November to 25 December 2019.

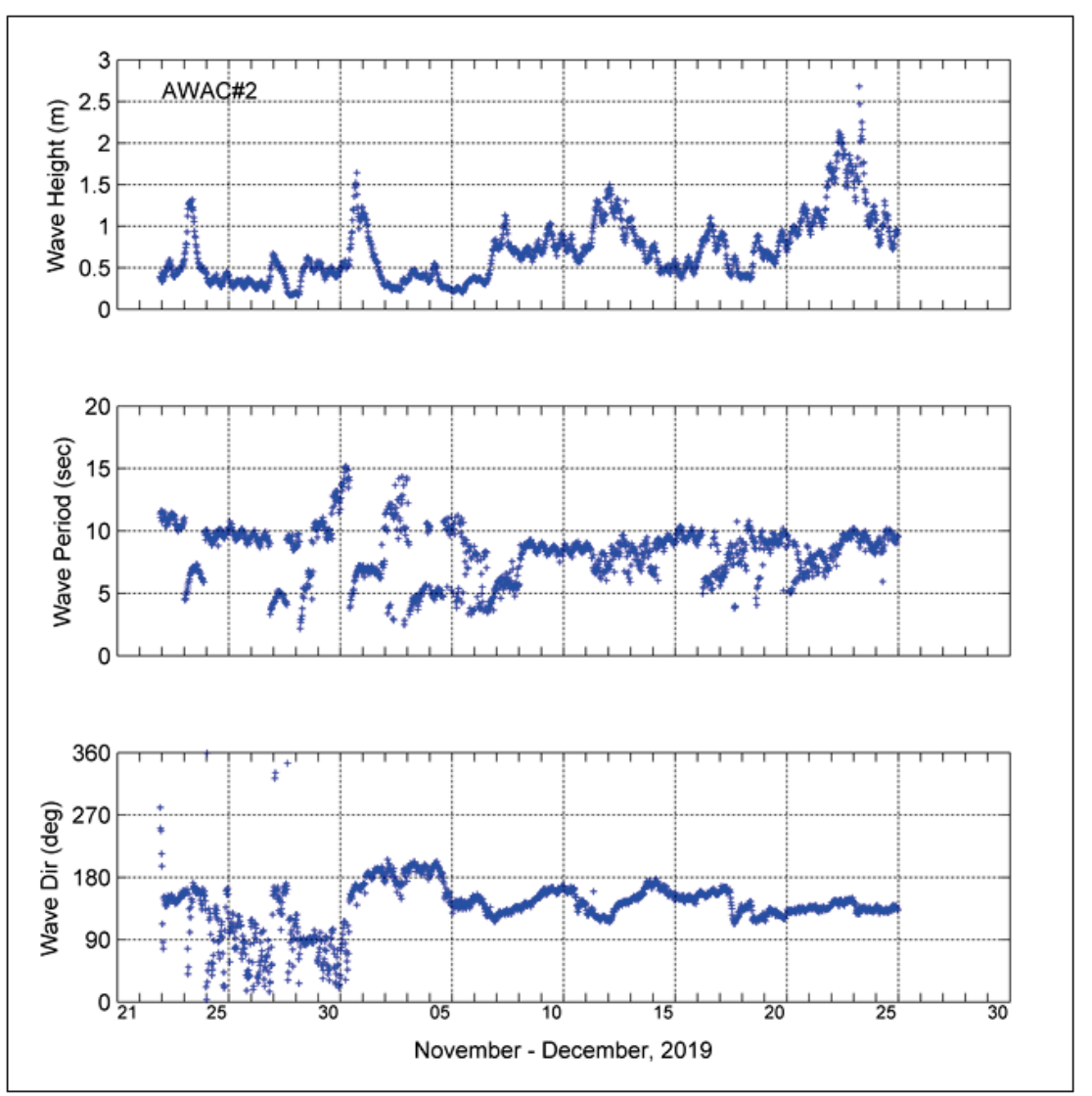

Figure 2-10. Wind speed and direction at NDBC Buoy 41029 from 21 November to 30 December 2019.

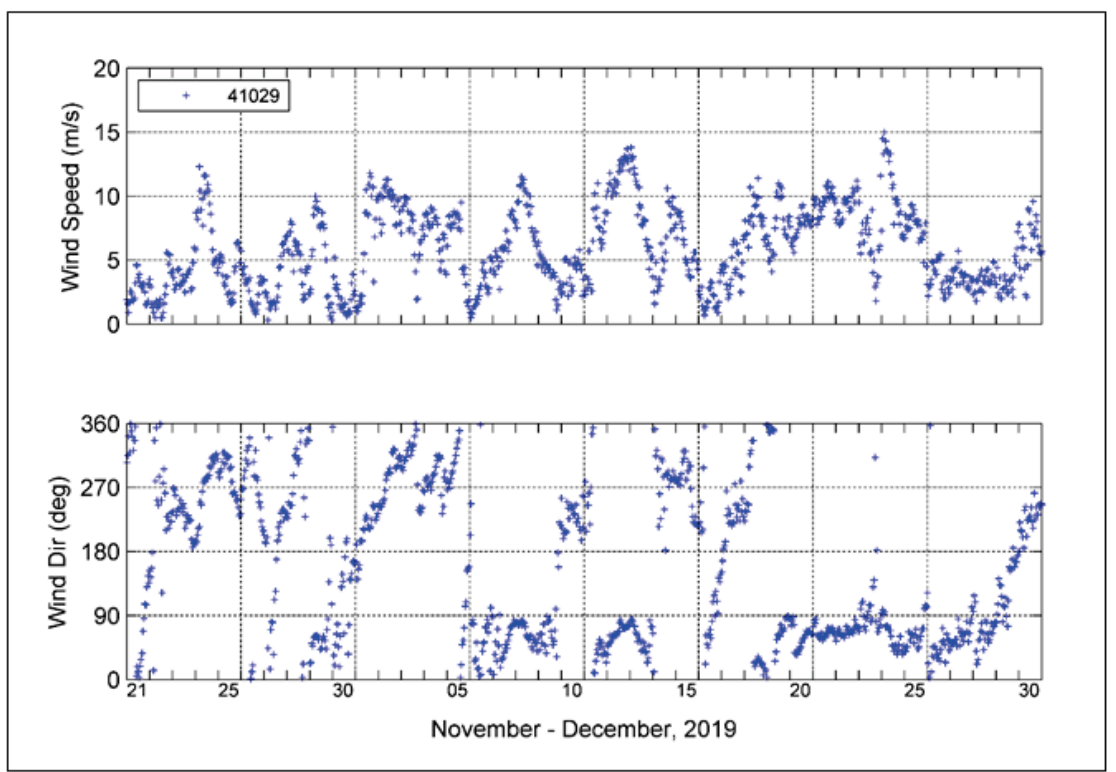




\section{Coastal Modeling System (CMS) Modeling}

The CMS is an integrated suite of numerical models for waves, flows, sediment transport, and morphology change in coastal and inlet applications. This modeling system includes representation of relevant nearshore processes for practical applications of navigation channel performance and sediment management at coastal inlets and adjacent beaches. The CMS consists of a hydrodynamic and sediment transport model (CMS-Flow) and a spectral wave transformation model (CMS-Wave) (Sanchez et al. 2011a,b; Lin et al. 2008). All pre- and post-processing for these models is performed within the ERDC SMS interface (Aquaveo 2020). The framework of CMS is shown in Figure 3-1.

Figure 3-1. The CMS framework.

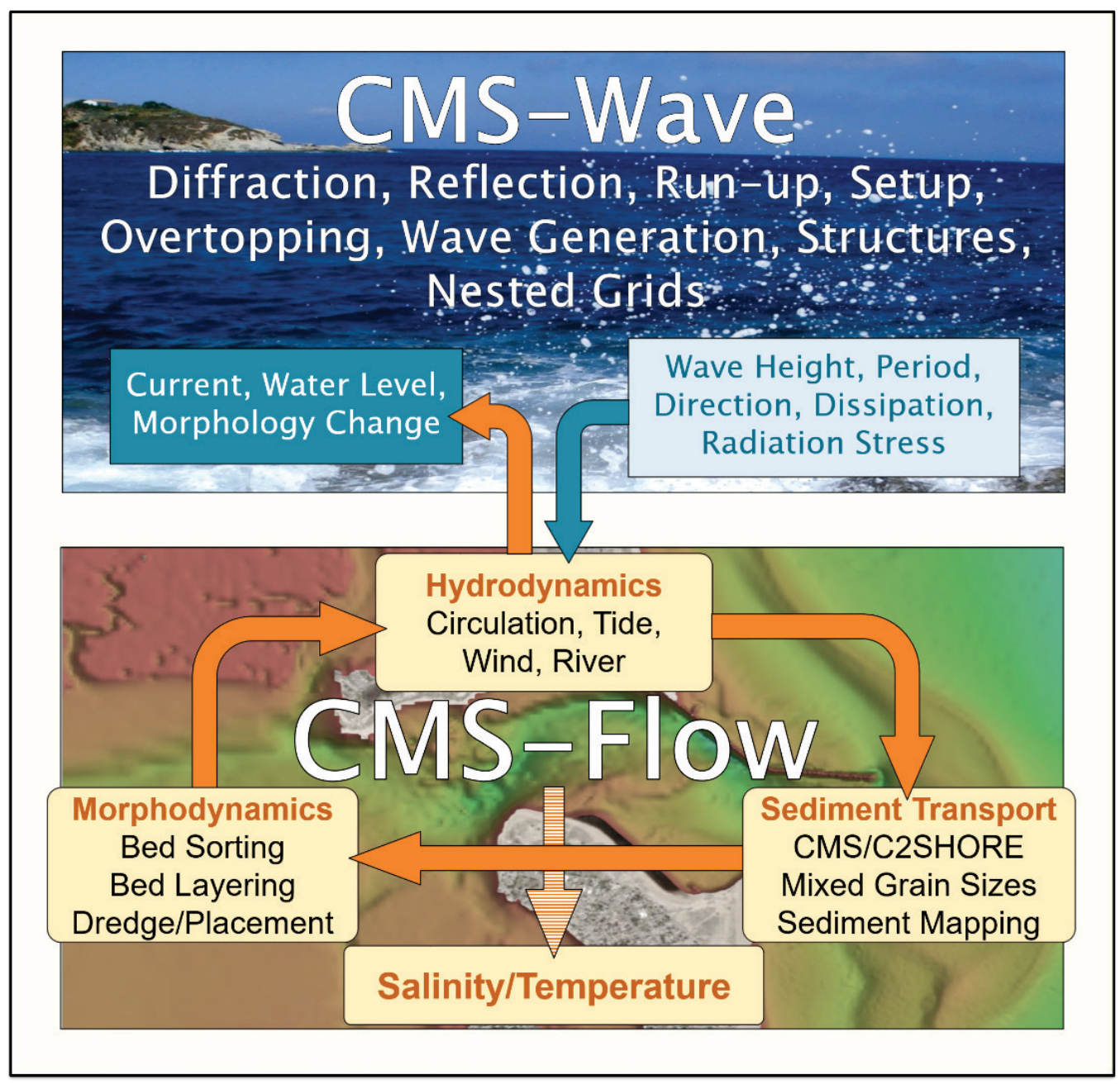


CMS-Flow is a two-dimensional depth-integrated finite-volume model that solves the mass conservation and shallow-water momentum equations of water motion on a non-uniform Cartesian grid. CMS-Flow calculates hydrodynamics, sediment transport, and morphology change due to tide, wind, and waves. Wave radiation stresses and other wave parameters are calculated by CMS-Wave and supplied to CMS-Flow for hydrodynamic and sediment transport calculations.

CMS-Wave is a spectral wave transformation model. It solves the steadystate wave-action balance equation on a non-uniform Cartesian grid and is designed to simulate wave processes with ambient currents at coastal inlets and in navigation channels. The model can be used either in halfplane or full-plane mode and includes coastal wave processes, such as wind wave generation and growth, refraction, diffraction, reflection, dissipation due to bottom friction, white-capping and breaking, wavecurrent interaction, wave runup, wave setup, and wave transmission through structures.

CMS-Flow and CMS-Wave have a dynamic coupling at a certain time interval specified by users. For the Stono Inlet application, CMS-Wave was run at a $1 \mathrm{hr}$ interval between CMS-Flow simulations.

\subsection{Model domain and model setup}

A telescoping variable-resolution CMS-Flow grid was developed for the Stono Inlet and Folly Beach area (Wu et al. 2011). The areal extent for the modeling domain is approximately $26.4 \mathrm{~km}(16.4 \mathrm{mi})$ alongshore and $24.8 \mathrm{~km}$ (15.4 mi) across shore. The CMS domain consists of 126,000 ocean cells, which cover the Stono Inlet, Folly Beach, Folly and Kiawah Islands, Stono and Folly Rivers, and the open ocean region (Figure 3-2). The water depth ranges from 1 to $2 \mathrm{~m}$ ( 3.28 to $6.56 \mathrm{ft}$ ) above mean sea level at tidal marsh areas to $11 \mathrm{~m}(36.09 \mathrm{ft})$ at the Folly River Navigation Channel and further increases to $16 \mathrm{~m}(52.5 \mathrm{ft})$ at the seaward boundary of the CMS domain. The telescoping grid system permits much finer local grid resolution to resolve hydrodynamic and sediment features in areas of high interest. For this study, the cell sizes vary from $10 \mathrm{~m}(32.81 \mathrm{ft})$ in front of Folly Beach and the Stono Inlet navigation channel to $320 \mathrm{~m}$ (1050 ft) in the open ocean. The CMS-Wave grid with varying cell sizes was generated for wave modeling, covering a smaller domain and with similar spatial resolution as the CMS-Flow grid (Figure 2-1 and Figure 3-2). 
Figure 3-2. The CMS domain. (a) Bathymetry at the inlet entrance channel and the bay, (b) CMS-Flow telescoping grid, and (c) CMS-Wave variable rectangular grid.
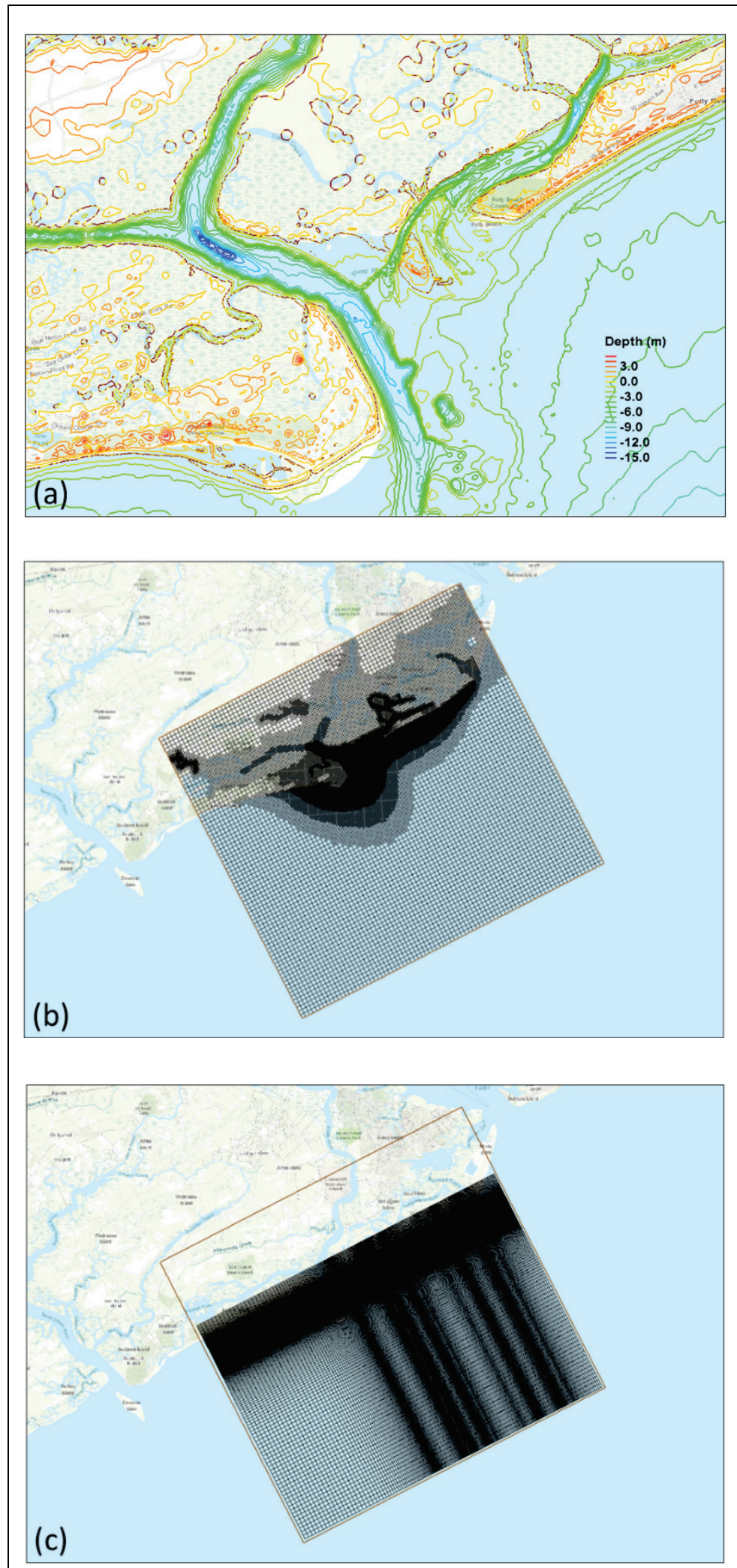


\subsection{Simulation periods}

The field survey was conducted from 22 November 2019 to 11 April 2020. Corresponding to the survey period, simulations for the CMS calibration and validation were set up from 21 November to 30 December 2019. For production simulations, a storm simulation (Hurricane Hugo, 1989) and a medium-to-long term simulation ( $1 \mathrm{yr}$ ) were set up.

\subsubsection{Hurricane Hugo}

Hurricane Hugo, a Category 4 hurricane, made landfall on Sullivan's Island, $20 \mathrm{~km}(12.4 \mathrm{mi})$ northeast of Stono Inlet, on 22 September 1989 and is considered one of the most damaging hurricanes on the coast of South Carolina. After moving inland, the wind speed quickly decreased, and Hurricane Hugo dissipated on 25 September 1989 (https://www.weather.gov/chs/HurricaneHugo-Sep1989, accessed 29 July 2021). Figure 3-3 shows the WSE and wind data, with the maximum surge and tidal level at $2.5 \mathrm{~m}(8.2 \mathrm{ft})$ above the MSL and the maximum wind speed of approximately $30.0 \mathrm{~m} / \mathrm{s}(98.43 \mathrm{ft} / \mathrm{s})$ at the NOAA coastal stations. Figure 3-4 shows the wave conditions with a maximum wave height close to $6.0 \mathrm{~m}(19.69 \mathrm{ft})$ and predominant wave direction from the east-southeast. As shown in Figure 3-3 and Figure 3-4, the CMS simulation period for Hurricane Hugo is from 18 to 25 September 1989. 
Figure 3-3. WSE and wind of Hurricane Hugo at NOAA gauge 8638610 (Charleston Harbor, South Carolina) and NDBC land station, FBIS1, respectively.

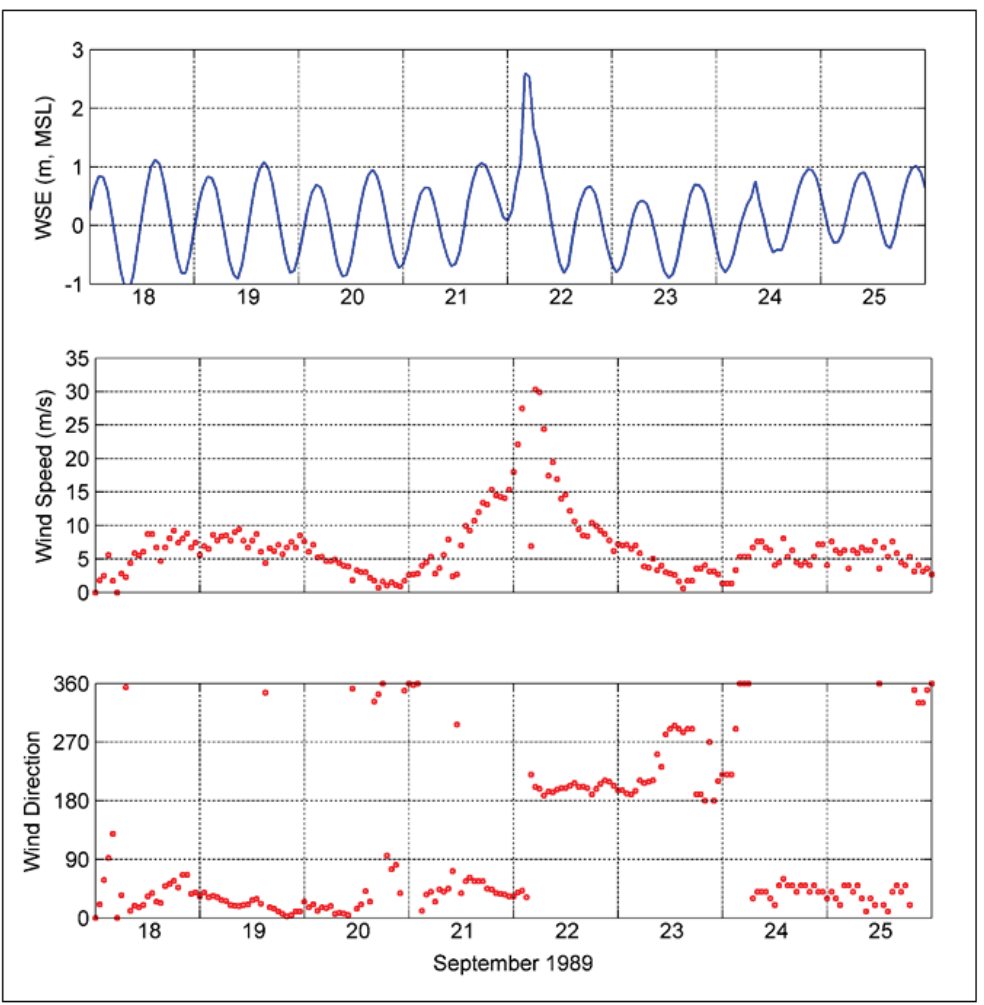

Figure 3-4. Wave parameters of Hurricane Hugo at WIS Station 63350.

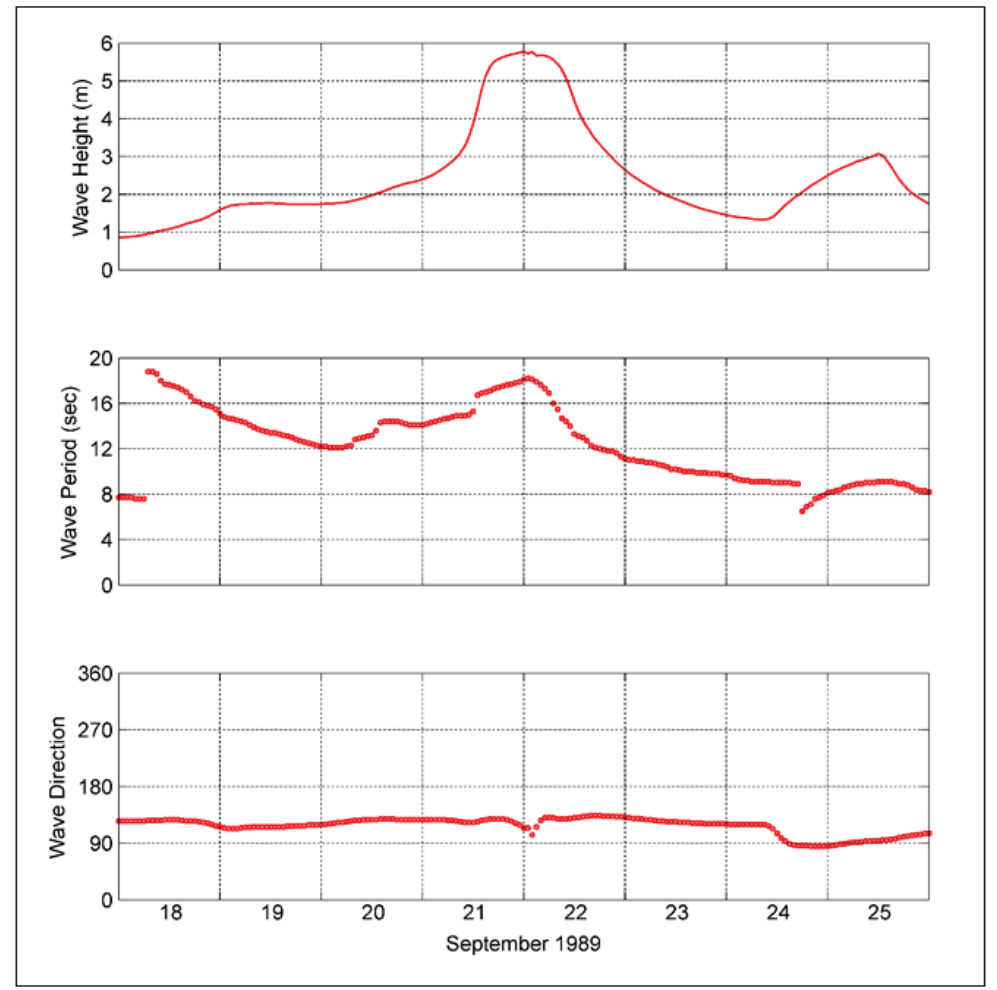




\subsubsection{A typical year (2018)}

As shown in Figure 2-4 and Figure 2-5, the complete wind and wave records were obtained at NDBC buoys 41029 and 41004, respectively, from 2015 to 2019. To select a typical year for the medium- to long-term CMS simulation, wind and wave roses for each of the annual datasets were compared with $5 \mathrm{yr}$ average wind and wave conditions.

Like the 2015-2019 wind rose, the 2018 wind rose shown in Figure 3-5 also displays two dominant shore-parallel wind directions, southwesterly and northeasterly, in the region. Southwesterly wind occurred close to $36 \%$ of the time while northeasterly wind approximately $29 \%$ of the time. Similarly, the northeasterly wind occurring in 2018 had a stronger speed. For the wind blowing from the northeast direction, a little more than $10 \%$ of time, the wind speed reached $10 \mathrm{~m} / \mathrm{s}(32.81 \mathrm{ft} / \mathrm{s})$ and above. The $5 \mathrm{yr}$ mean wind speed is approximately $5.7 \mathrm{~m} / \mathrm{s}(18.7 \mathrm{ft} / \mathrm{s})$.

Figure 3-5. 2018 wind rose at the NDBC buoy 41029.

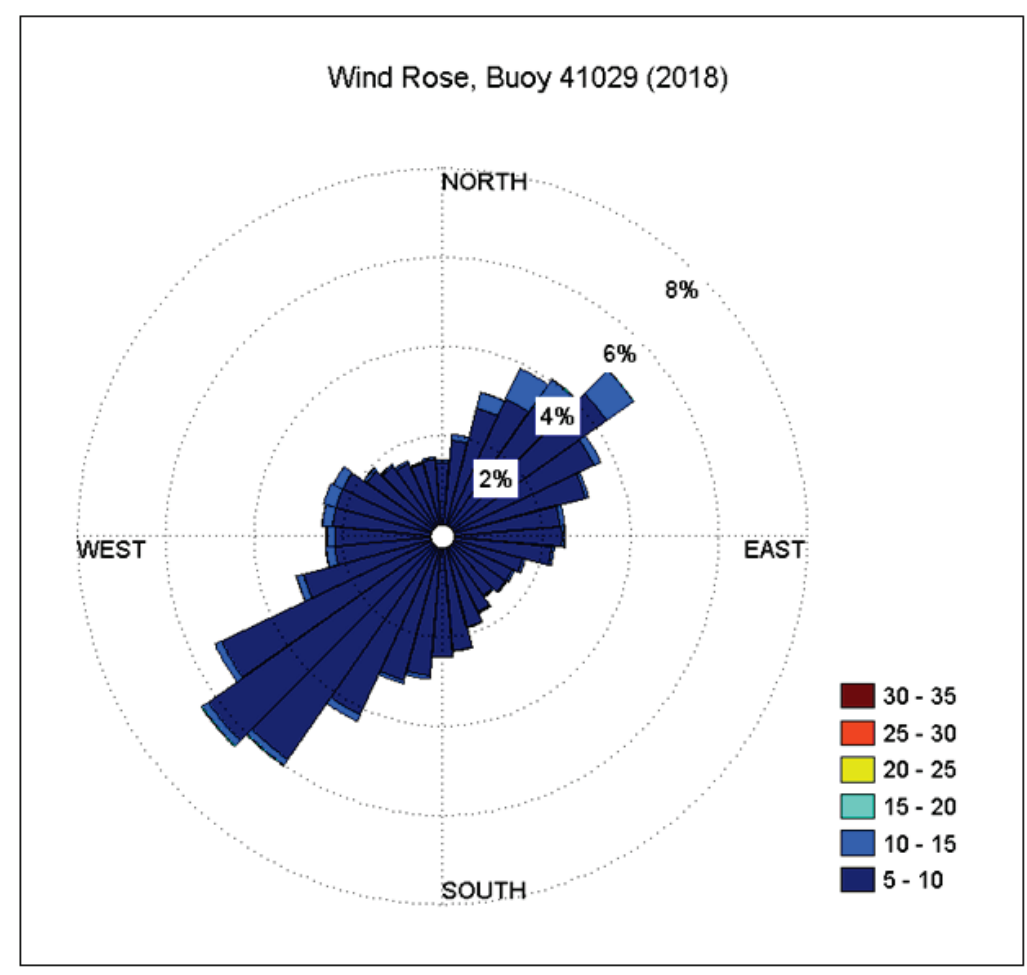

As shown in Figure 3-6 the 2018 wave rose at Buoy 41004 indicates that $59 \%$ of the time, waves propagate from the southeast sector, close to the shore normal direction. The secondary dominant wave direction is approximately parallel to shoreline, propagating from the southwest 
direction and occurring close to $19 \%$ of the time. Benign wave conditions were also evident in the 2018 wave data. Approximately $11 \%$ of the time, significant wave heights are above $2 \mathrm{~m}(6.56 \mathrm{ft})$ for waves propagating from the southeast and southwest directions. The 2018 mean significant wave height is the same as the $5 \mathrm{yr}$ mean of $1.3 \mathrm{~m}(4.27 \mathrm{ft})$, and the peak wave height is also between 5 and 6 m (16.4 and 19.69 ft), occurring in April 2018.

Figure 3-6. 2018 wave rose at the NDBC buoy 41004.

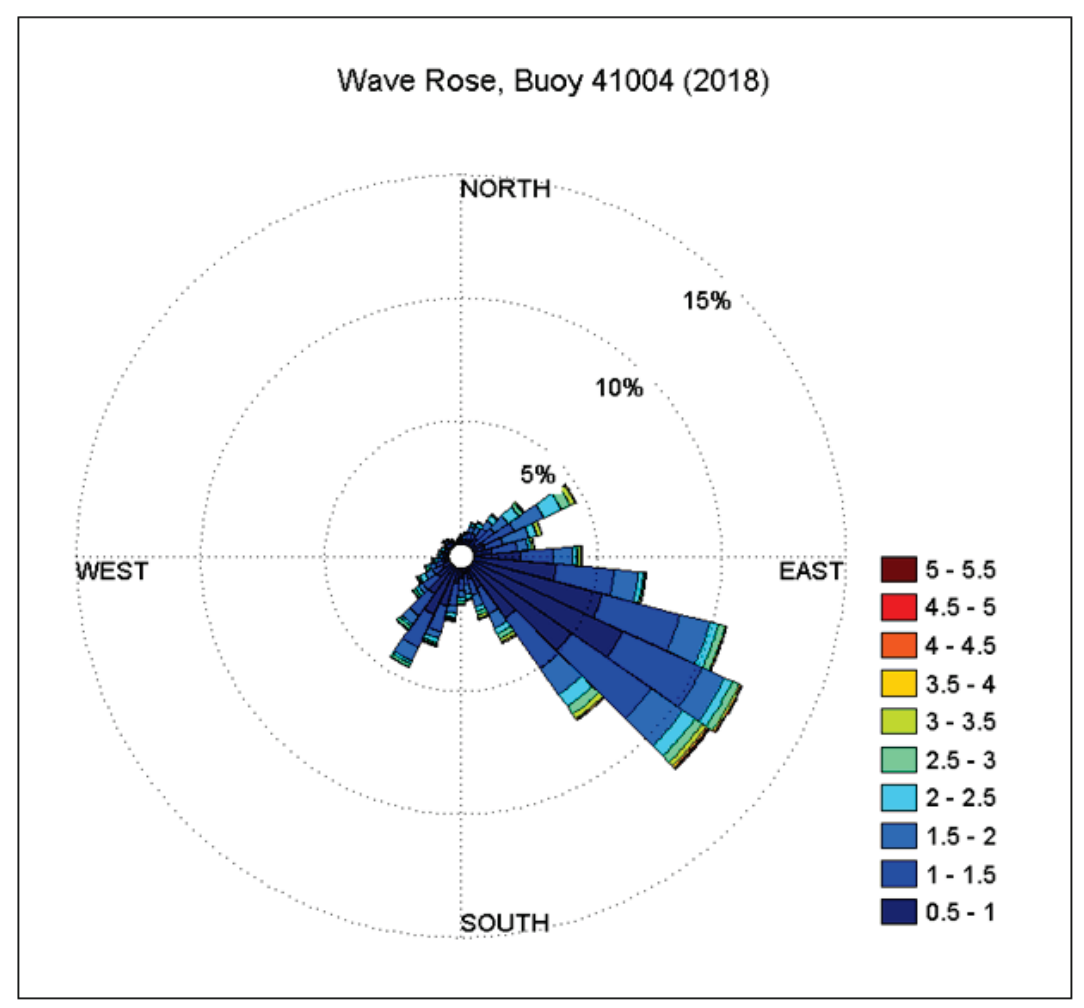

Figure 3-5 and Figure 3-6 illustrate that the 2018 wind and wave data present similar rose patterns and statistical properties as the 2015-2019 data. Therefore, the year of 2018 is selected to represent a typical year, and the 2018 data are used to configure the medium- to long-term simulation.

\subsection{Model forcing}

The forcing to drive the CMS includes WSE and wind stress along the open boundaries and at the surface boundary of CMS-Flow, and wave spectrum at the seaward boundary of CMS-Wave. Normally, measured data at an adjacent site to model boundaries or model domain are the ideal choice for driving forces. However, in situ measurements can be interrupted by unforeseen factors, such as weather conditions or instrument failure. Very 
often the driving forces of a numerical model have to rely on hindcast products like the WIS dataset or use multiple survey sites to obtain one complete time series. Three simulation periods were selected in the study: (1) the calibration and validation, (2) Hurricane Hugo, and (3) the year of 2018, for which expected forcing data may or may not be available.

NOAA tide gauge (\#8665530) at Charleston Harbor, SC, provides the complete water level records for all three simulation periods. Initial data analysis shows that tidal phase at the harbor gage site leads that at Stono Inlet by approximately $0.8 \mathrm{hr}$. The phase difference was adjusted when water levels were specified along the CMS ocean boundary.

For the model calibration and validation period, wind data were downloaded from the Charleston Harbor gauge \#8665530, the NOAA coastal station FBIS1, and the NOAA offshore buoy \#41029. Wind speeds and directions were compared among the three sites and were used to test the CMS (Figure 3-7). Overall, the stronger wind speeds occurred at the offshore buoy and the wind directions among three gauges had an angle difference of approximately $0^{\circ}-90^{\circ}$ through the period. Because of the sheltering effect, the harbor gauge shows the weakest wind speeds and the largest difference in wind directions. The CMS simulation driven with the offshore buoy wind yielded the best results.

Figure 3-7. Wind speeds and directions at NOAA Charleston Harbor tide gauge \#8665530, the NOAA coastal station FBIS1, and the NOAA offshore buoy \#41029 from 21 November to 30 December 2019.

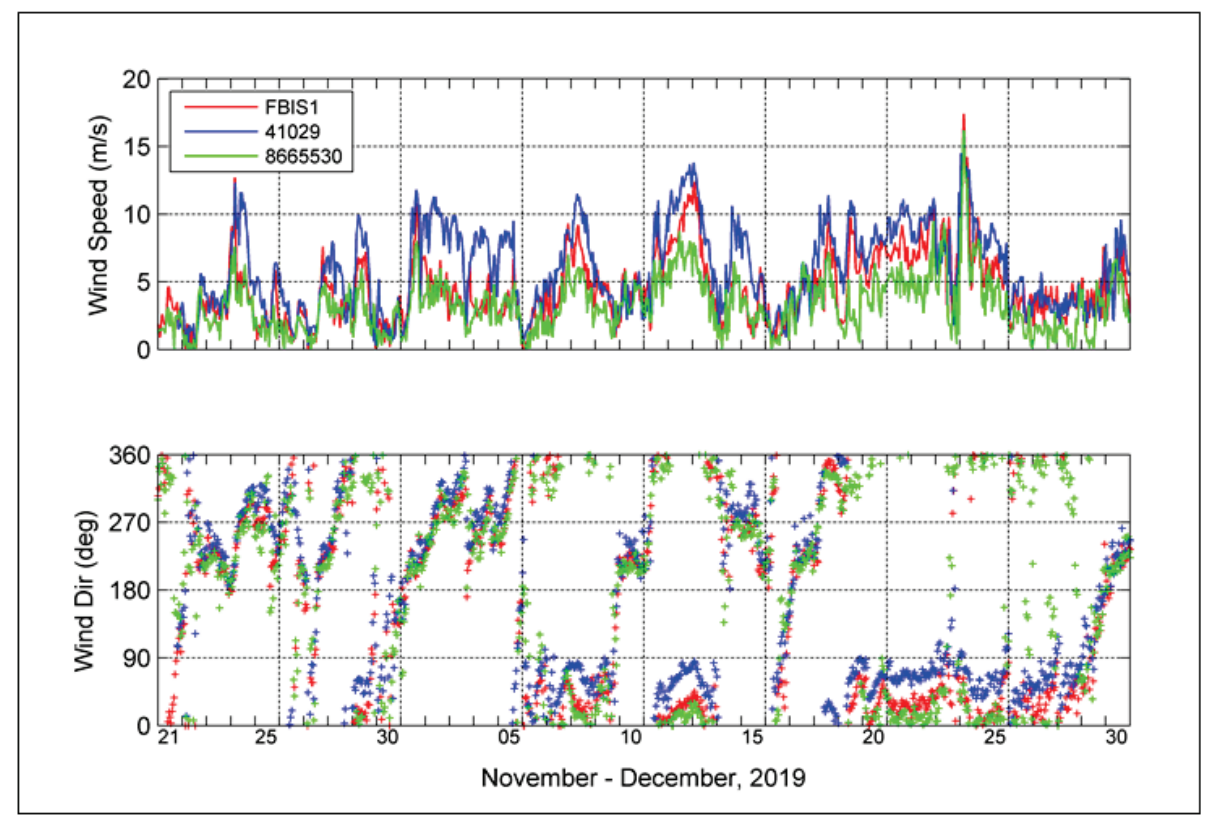


Besides selecting the buoy wind for the model calibration and validation period, the wind data from Buoy \#41029 were also used for the 2018 simulation. Data gaps existing in the original measurements were filled with the wind data from the NOAA coastal station FBIS1.

NOAA buoy \# 41029 had not been operational until 2005. Therefore, during the Hurricane Hugo period, the wind data at FBIS1 were employed as the forcing term to drive the model and to reproduce wind-driven current in the model domain. After the hurricane passage, there is a 20-day data gap starting from 23 September 1989 at the station, which corresponds to the last 2 days of the CMS simulation with a wind speed less than $10 \mathrm{~m} / \mathrm{s}$ $(32.81 \mathrm{ft} / \mathrm{s})$. The gap was filled using the measured wind data at the Charleston Harbor (Figure 3-3).

Directional wave spectra are often used to drive a wave model because of the inclusion of the total wave energy. NOAA Buoy \#41004 is the closest offshore site to Stono Inlet, where directional wave spectra are measured. For the calibration/validation and the 2018 simulations the hourly spectra at this location were transformed to the seaward open boundary of CMSWave. During the Hurricane Hugo period, the spectral wave data were not available at this buoy site. Hindcast wave parameters at WIS station \#63350 were used to generate wave spectra by a self-similar (TMA) spectral shape for the CMS-Wave input (Lin et al. 2008).

\subsection{Model alternatives}

Sediment management alternatives were developed based on sand dredge in designated areas around Stono Inlet and placement on Folly Beach. 2.5 MCY (1.9M m3) of sediment are removed from a projected borrow site, and the materials are placed in 26 reaches along the beach for building berms and dune (Figure 3-8). Figure 3-9 shows the sketches of designed berms and dunes for reaches 2-21 and 22-26. Along the stretch of the shoreline, the dune has a height of $4.64 \mathrm{~m}(15.2 \mathrm{ft})$ with a crest width of $1.5 \mathrm{~m}(5 \mathrm{ft})$ relative to MSL. The berm has a height of $2.51 \mathrm{~m}(8.2 \mathrm{ft})$ with a top width of $10.7 \mathrm{~m}$ ( $35 \mathrm{ft}$ ) for reaches $2-21$ and $15.2 \mathrm{~m}$ (50 ft) for reaches 22-26. This initial design was used for the current modeling study. The final design will include the same general berm and dune but might differ slightly in overall project length and reach scales. 
Figure 3-8. The reach map along Folly Beach.

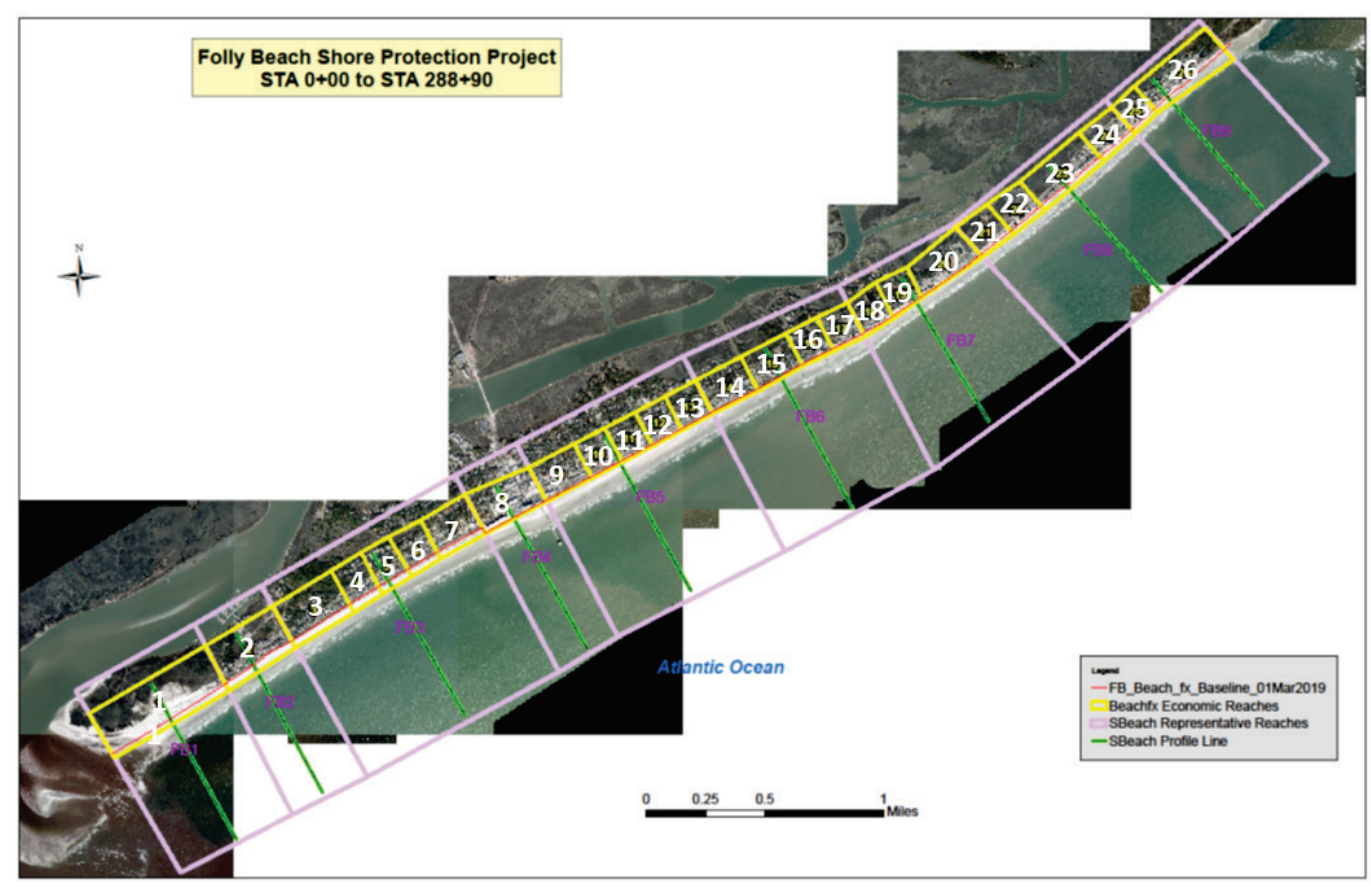

Figure 3-9. Sketches of designed berms and dunes for (a) reaches 2-21, (b) reaches 22-26.

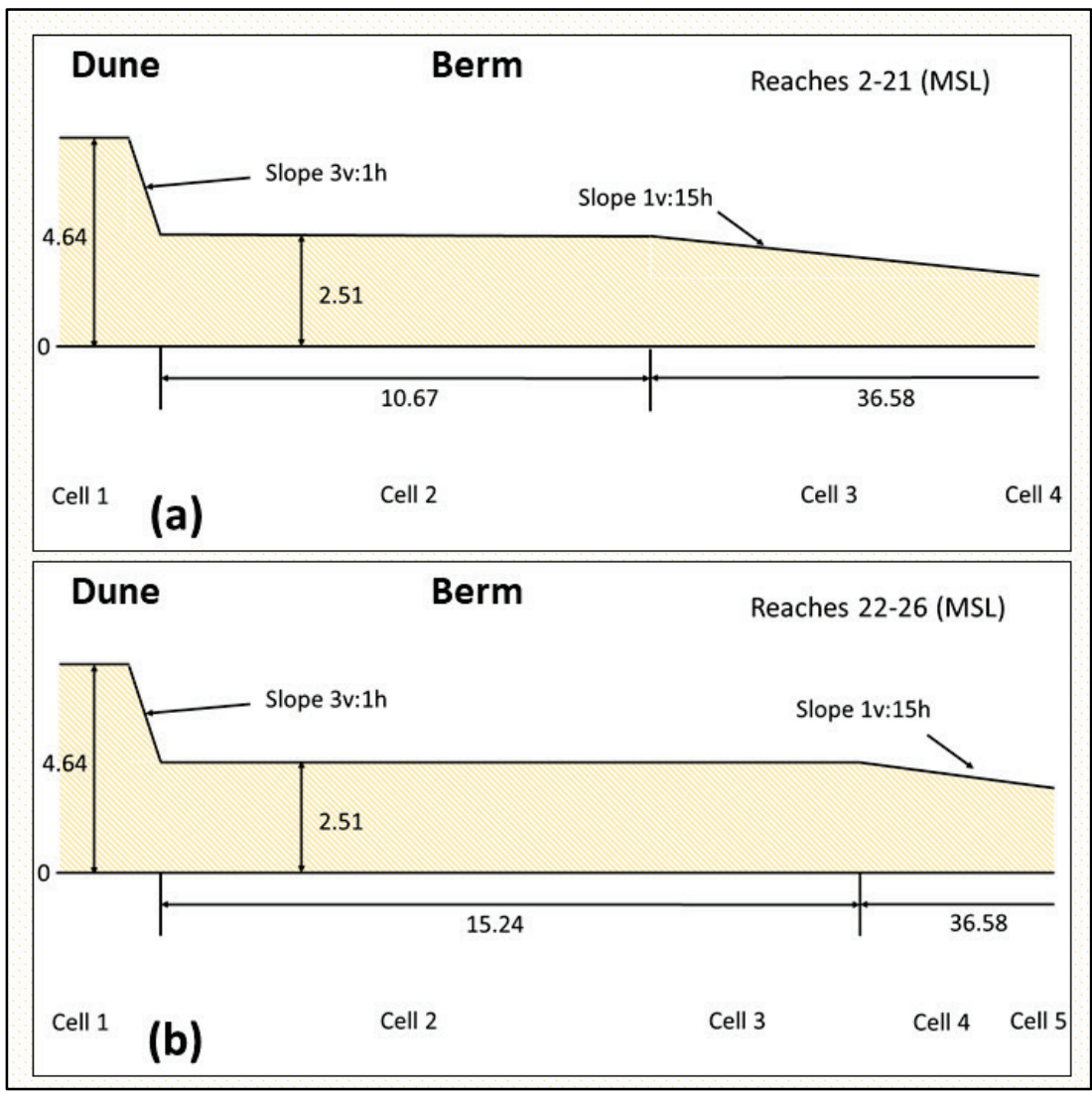


Figure 3-10 shows the distribution of bathymetry and topography along Folly Beach before and after berm/dune placement. With this setup along the shoreline, five alternatives were specified corresponding to five designated borrow areas (Figure 1-1). From each area approximately 2.5 MCY (1.9 M m3) of beach quality materials were dredged for the beach fill.

Figure 3-10. CMS bathymetry/topography along Folly Beach for (a) base case and (b) with built berm and dune.

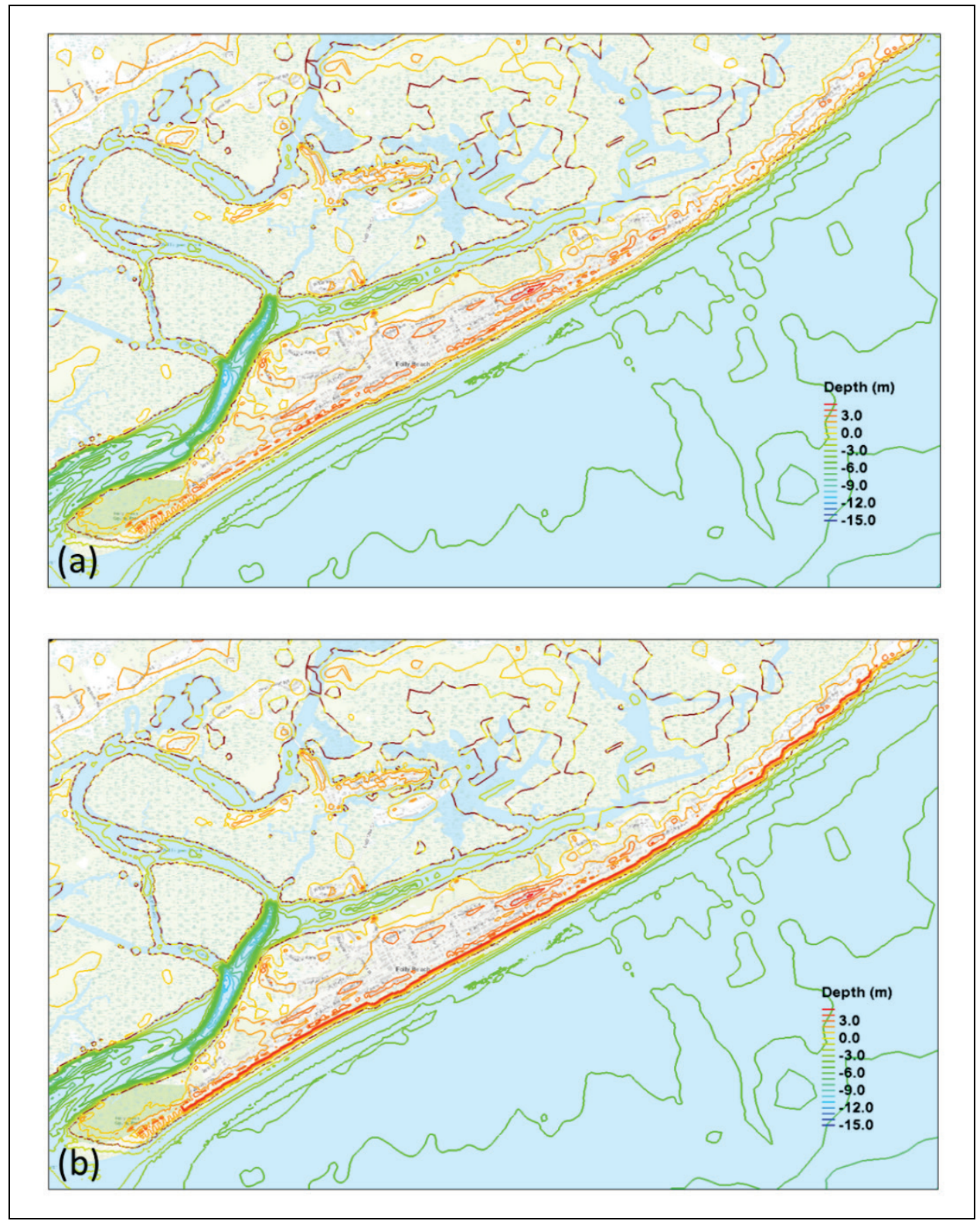




\subsubsection{Borrow area: Folly River (Alternative 1)}

The Folly River borrow area is located downstream of the Folly River and interrupts the Folly River navigation channel with shallow depths (Figure 1-1 and Figure 3-11). The base case shows that the average water depth is $2.56 \mathrm{~m}(8.4 \mathrm{ft})$ within the area, and the deepest portion is

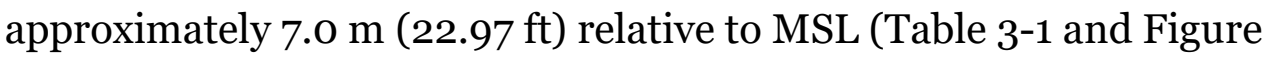
3-11a). For the alternative setup, most of the area was dreadged to $7.85 \mathrm{~m}$ $(25.76 \mathrm{ft})$, and only the small portion of the area at the southwest corner was not dredged. The total sediment volume obtained from the area is approximately 2.50 MCY (1.91 M m3). After dredging, the average water depth within the area is $5.3 \mathrm{~m}(17.39 \mathrm{ft})$ (Figure $3-11 \mathrm{~b})$.

Figure 3-11. Bathymetry of Folly River borrow area. (a) base case (before dredge); (b) Alternative 1 (after dredge).

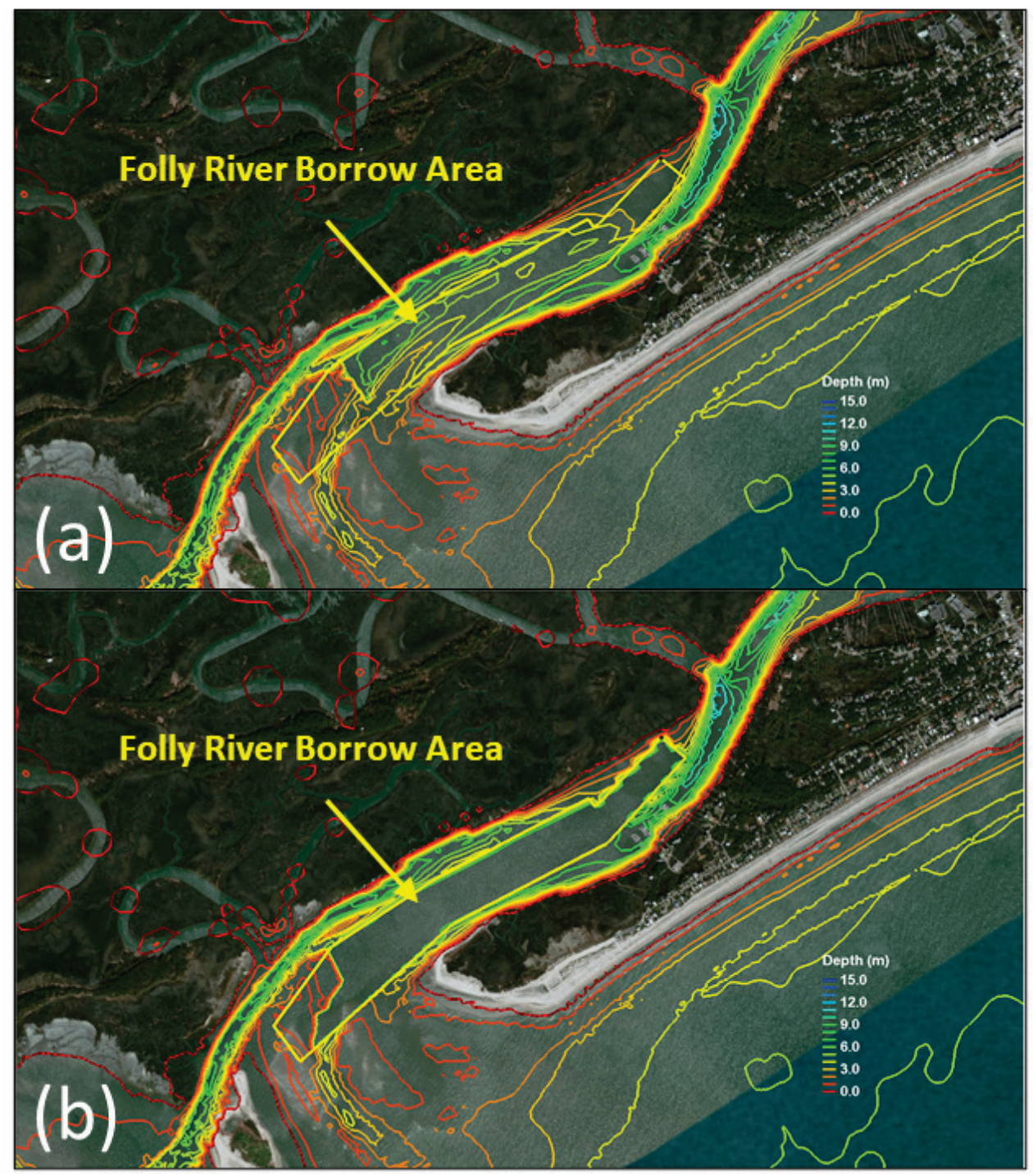


Table 3-1. Physical scales of the five borrow areas (Figure 1-1).

\begin{tabular}{|l|l|l|l|l|}
\hline Alternative & Borrow Area & Size $\left(\mathrm{m}^{2}\right)$ & $\begin{array}{l}\text { Average Depth } \\
\text { before Dredge } \\
(\mathrm{m})\end{array}$ & $\begin{array}{l}\text { Average Depth } \\
\text { after Dredge }(\mathrm{m})\end{array}$ \\
\hline 1 & Folly River & 613700 & 2.6 & 5.3 \\
\hline 2 & $\begin{array}{l}\text { Stono Inlet } \\
\text { Throat }\end{array}$ & 3148200 & 4.9 & 5.3 \\
\hline 3 & $\begin{array}{l}\text { Stono Ebb } \\
\text { Shoal 1 }\end{array}$ & 2024930 & 5.9 & 6.9 \\
\hline 4 & $\begin{array}{l}\text { Stono Ebb } \\
\text { Shoal 2 }\end{array}$ & 874680 & 10.2 & 12.1 \\
\hline 5 & Stono Inlet & 10543800 & 11.2 & 11.4 \\
\hline
\end{tabular}

\subsubsection{Borrow area: Stono Inlet Throat (Area I, Alternative 2)}

Part of the Stono Inlet Throat borrow area covers the Stono River navigation channel, and approximately $70 \%$ of the borrow area is located in the shallow part of the area (Figure 1-1 and Figure 3-12). The base case shows that the average water depth is $4.9 \mathrm{~m}(16.08 \mathrm{ft})$ within the area and the deepest portion is approximately $10.0-11.0 \mathrm{~m}(32.81-36.09 \mathrm{ft})$ relative to MSL (Table 3-1 and Figure 3-12a). Because the channel area already reached an average depth of $8.6 \mathrm{~m}(28.22 \mathrm{ft})$, sediment dredging was focusing on the shallow area for the development of the alternative, which was dredged to $7.55 \mathrm{~m}(24.77 \mathrm{ft})$. The total sediment volume obtained from the area is also approximately 2.50 MCY $\left(1.91 \mathrm{M} \mathrm{m}^{3}\right)$. After dredging, the average water depth within the area is $5.3 \mathrm{~m}$ (17.39 ft) (Figure 3-12b), a $0.4 \mathrm{~m}(1.31 \mathrm{ft})$ increase comparing with the average before dredging. 
Figure 3-12. Bathymetry of Stono Inlet Throat borrow area (Area I). (a) base case (before dredge); (b) Alternative 2 (after dredge).

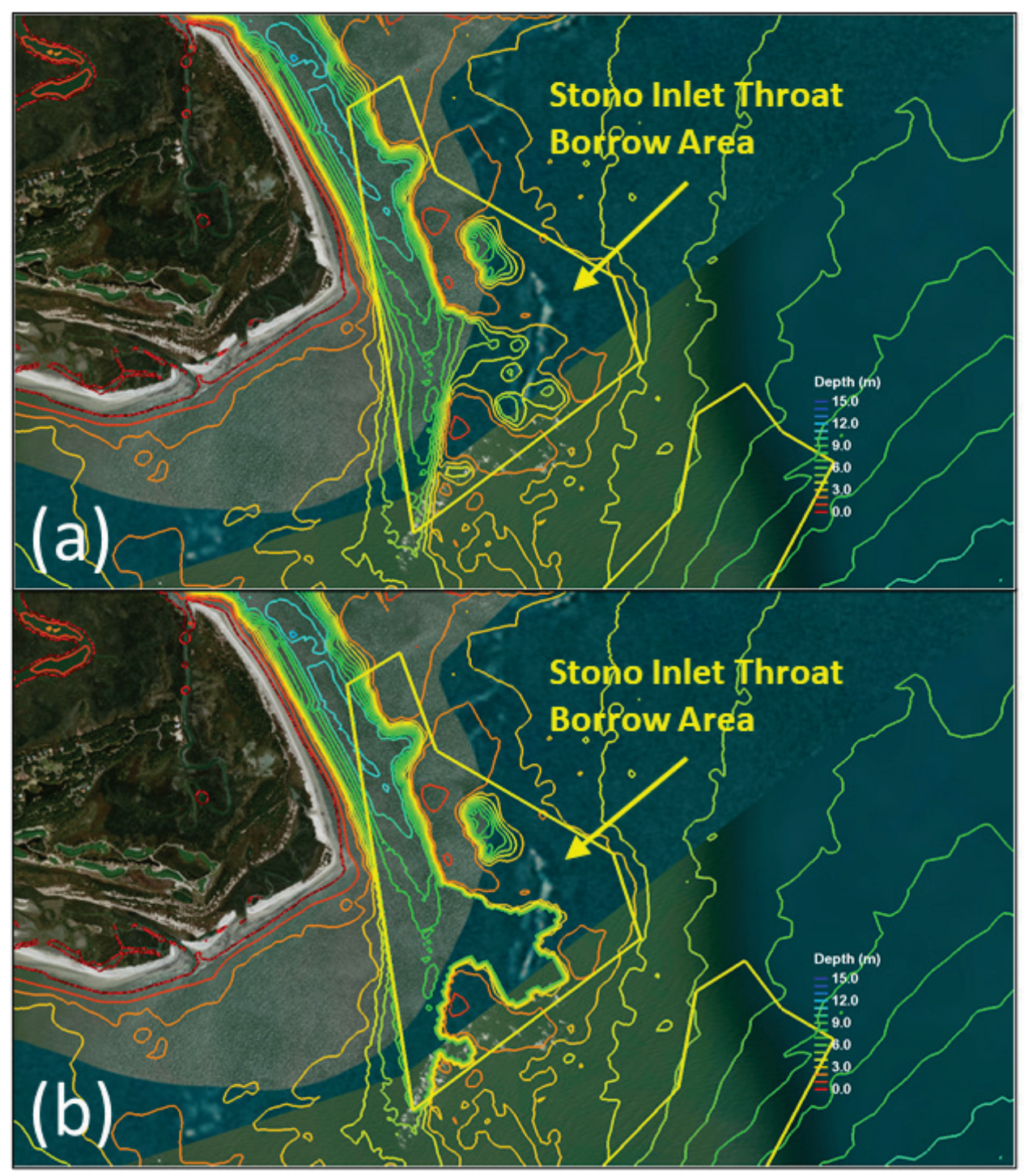

\subsubsection{Borrow area: Stono Ebb Shoal 1 (Area J, Alternative 3)}

The Stono Ebb Shoal 1 borrow area is just off the shallowest ebb shoal on the slope facing the open ocean (Figure 1-1 and Figure 3-13). The base case shows that the average water depth is $5.9 \mathrm{~m}(19.36 \mathrm{ft})$ within the area and the greatest water depth is approximately $8.0 \mathrm{~m}(26.25 \mathrm{ft})$ relative to MSL (Table $3-1$ and Figure $3-13 a$ ). Within the area, sediment dredging also went to $7.55 \mathrm{~m}(24.77 \mathrm{ft})$ if the water depth was less than that value. The total sediment volume obtained from the area is approximately 2.52 MCY (1.92 $\mathrm{M} \mathrm{m}^{3}$ ). After dredging, the average water depth within the area is 6.9 $\mathrm{m}(22.64 \mathrm{ft})$ (Figure 3-13b), a $1.0 \mathrm{~m}$ (3.28 ft) increase comparing with the average before dredging. 
Figure 3-13. Bathymetry of Stono Ebb Shoal 1 borrow area (area J). (a) base case (before dredge); (b) Alternative 3 (after dredge).

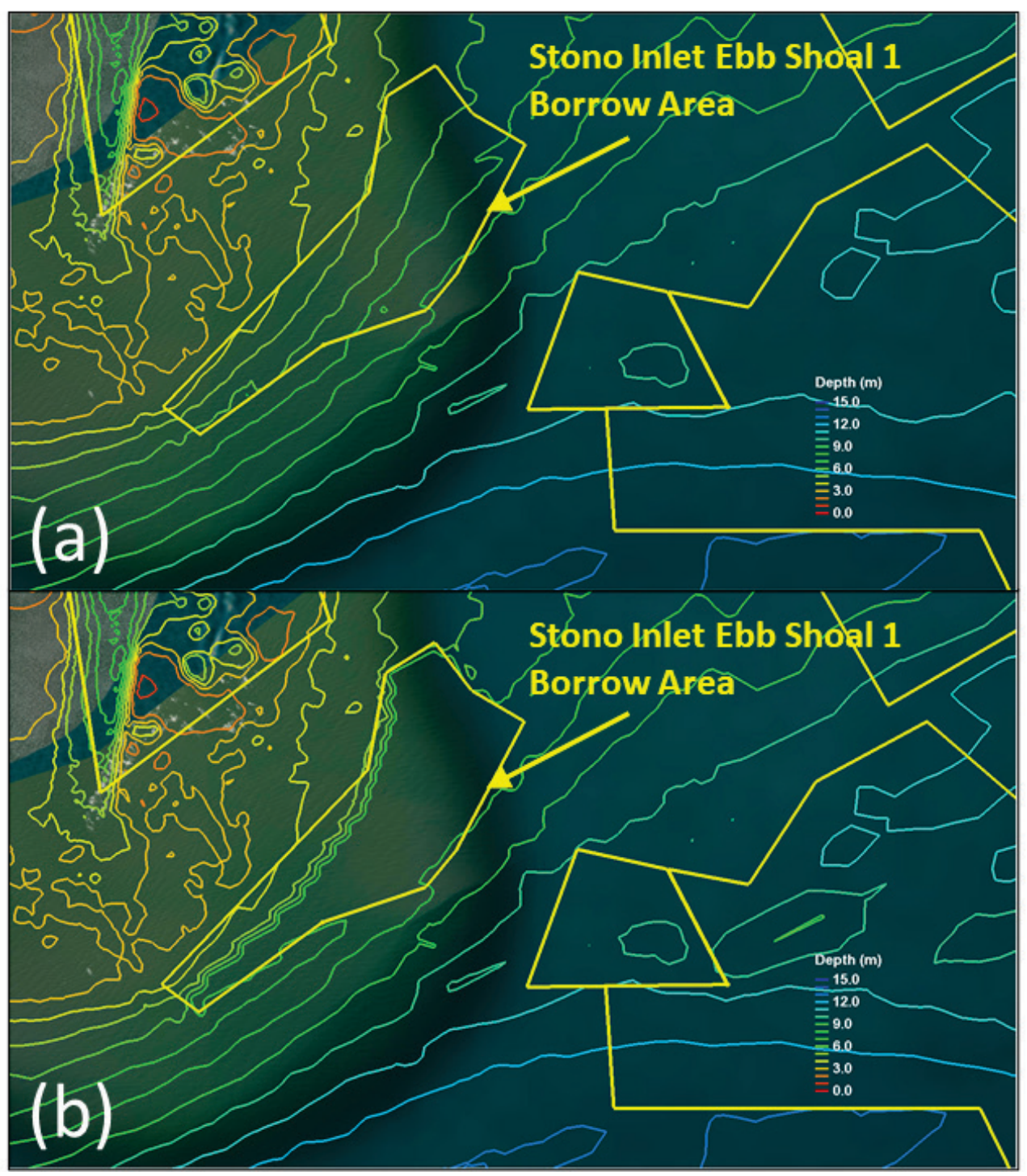

\subsubsection{Borrow area: Stono Ebb Shoal 2 (Area K, Alternative 4)}

The Stono Ebb Shoal 2 borrow area is the second smallest area, and only a little larger than the Folly River area, but the water is much deeper (Table 3-1 and Figure 1-1). The base case shows that the average water depth is $10.2 \mathrm{~m}$ (33.47 ft) within the area, and the greatest water depth is close to $11.0 \mathrm{~m}$ (36.09 $\mathrm{ft}$ ) relative to MSL (Figure $3-14 \mathrm{a})$. For this alternative, the entire area had to be dredged to $12.1 \mathrm{~m}(39.7 \mathrm{ft})$ to obtain sufficient amount of sediment materials (Figure 3-14b). The total sediment volume obtained from the area is approximately 2.54 MCY (1.94M m3). After dredging, the average water depth within the area is 
12.1 m (39.7 ft) (Figure 3-14b), approximately a $2.0 \mathrm{~m}(6.56 \mathrm{ft})$ increase comparing with the average before dredging.

Figure 3-14. Bathymetry of Stono Ebb Shoal 2 borrow area (Area K). (a) base case (before dredge); (b) Alternative 4 (after dredge).

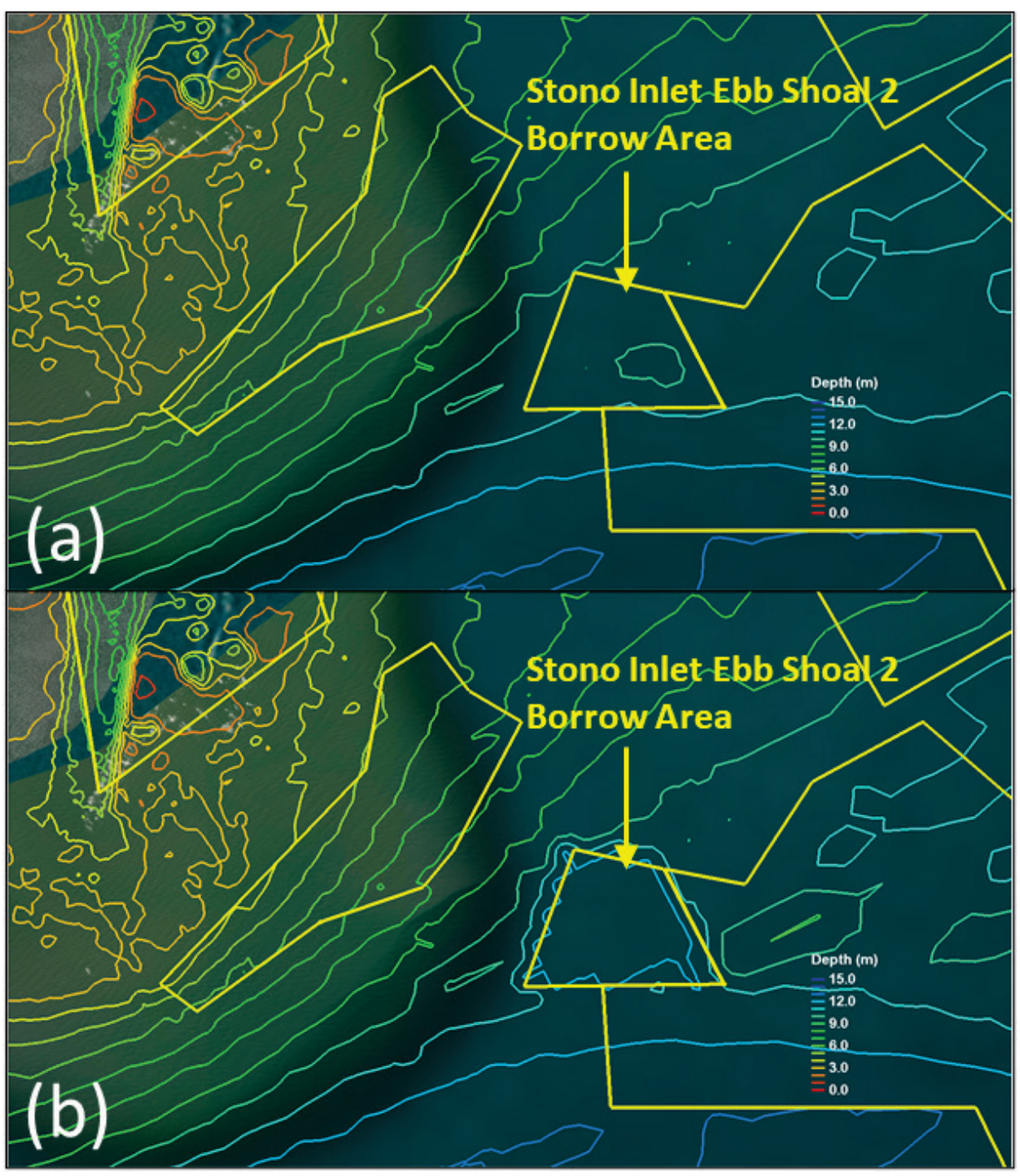

\subsubsection{Borrow area: Stono Inlet (Area E, Alternative 5)}

The Stono Inlet borrow area is the largest among the five areas and located in deeper offshore zone (Table 3-1, Figure 1-1, and Figure 3-15). The base case shows that the average water depth is $11.2 \mathrm{~m}(36.75 \mathrm{ft})$ within the area, and the greatest water depth is close to $13.0 \mathrm{~m}(42.65 \mathrm{ft})$ relative to MSL (Figure 3-15a). For this alternative, the central portion of the area with the depth less than $11.1 \mathrm{~m}$ (36.42 ft) was dredged to $10.6 \mathrm{~m}$ or $11.1 \mathrm{~m}$ (34.78 or $36.42 \mathrm{ft}$ ) to obtain proper amount of sediment materials. The 
total sediment volume obtained from the area is approximately 2.50 MCY $(1.91 \mathrm{M} \mathrm{m} 3)$. After dredging, the average water depth within the area is 11.4 $\mathrm{m}$ (37.4 ft) (Figure 3-15b), only an increase of $0.2 \mathrm{~m}$ ( $0.66 \mathrm{ft}$ ) comparing with the average before dredging because of the large coverage of this borrow area.

Figure 3-15. Bathymetry of Stono Inlet borrow area (Area E). (a) base case (before dredge); (b) Alternative 5 (after dredge).

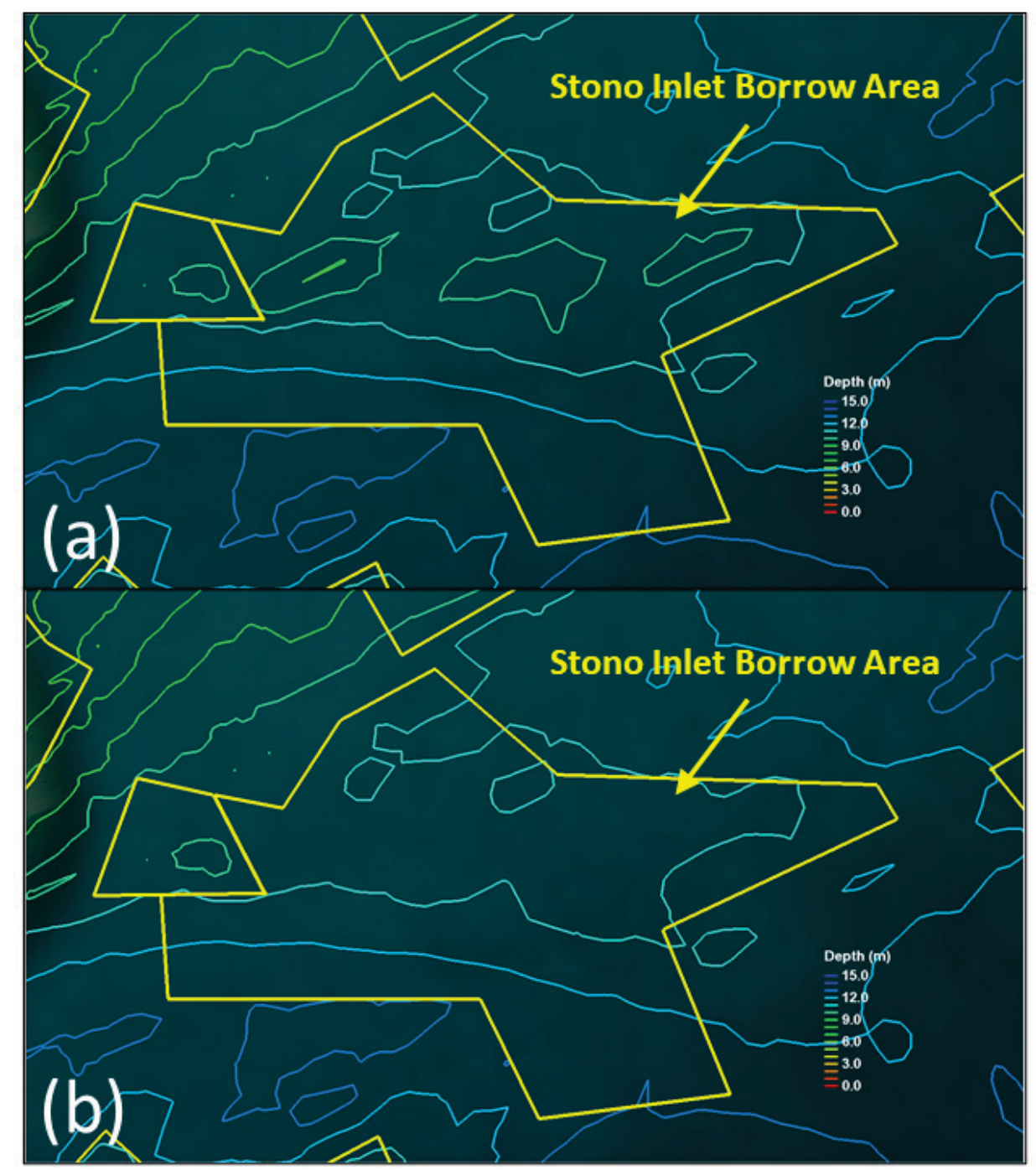

Five alternatives were described above. For each alternative, 2.5 MCY $\left(1.91 \mathrm{M} \mathrm{m}^{3}\right)$ of sediment are required to be dredged from the respective borrow area. Accounting for the different size of the designated areas, the actual borrow site can be smaller to obtain required materials. Figure 1-1 shows both designated borrow areas and actual borrow areas for each alternative. 


\section{Simulation Results and Analysis}

\subsection{Model calibration and validation}

WSE, current, and wave measurements in the Stono River channel and in the nearshore open area (AWAC\#1 and AWAC\#2) were used as the comparative data for the CMS calibration/validation (Figure 2-2). The calibration/validation period is from 21 November to 25 December 2019. WSE, wind, and wave data were used as input, and model results were compared with the AWAC data. The input data were obtained from NOAA ocean buoys, NOAA coastal gages, and a WIS station (see Chapter 2). Calibration procedures included the examination of boundary conditions and tuning of adjustable model parameters, such as bottom friction, wall friction, tidal prism, etc.

For this coastal and estuarine application, spatially varying Manning's $n$ values were specified in the model domain. In the main river channels and in shallow coastal area, Manning's $n$ was 0.017. The values were increased to 0.025 moving from nearshore inlet to offshore areas. Considering the extent of tidal marsh vegetation, Manning's $n$ values of 0.025 and 0.03 were used for wetlands in the estuary. Along riverbanks and coastal line, the default wall friction in the CMS was turned off. In addition, singlegrain size sediment transport modeling was conducted in the study. Referring to the sediment grab sample analysis (Figure 2-6), the sediment transport grain size, D50, was set to $0.18 \mathrm{~mm}$.

Four radiation open boundaries were specified in the model (Figure 3-2). The offshore open boundary was driven by WSE. The Stono River, Kiawah River, and Schooner Creek open boundaries had been assigned a zero value. With spatially varying Manning coefficients, the settings of the other parameters and specifications of boundary forcing, final hydrodynamic and wave calibration and validation results were obtained.

To quantitatively demonstrate model skill in the calibration and validation process, goodness-of-fit statistics were calculated for water levels, current velocities, and wave parameters, which included the calculation of the correlation coefficient (R), Root-Mean-Square Error (RMSE), and Normalized Root-Mean-Square Error (NRMSE). The correlation coefficient $\mathrm{R}$ measures the linear co-variation between two datasets and can range from -1 to 1 , with negative $R$ values indicating inverse correlation and a 
value of 1 indicating perfect agreement. The RMSE measures the actual differences between the measured and calculated datasets, and the NRMSE is defined as RMSE divided by data range and measures the relative differences between the measured and calculated datasets.

Figure 4-1 shows the scatter plots of calculated and measured currents at AWAC\#1 and AWAC\#2. $U$ is the east-west velocity component and $V$ the north-south velocity component. The principal current direction represents the along-channel flow at AWAC\#1 and the longshore current at AWAC\#2. The positive $\mathrm{V}$ values at AWAC\#1 indicate the flood tidal current, and the negative indicate the ebb tidal current. Both the calculated and measured principal current axes have an angle of approximately $-60^{\circ}$ relative to north (Figure 4-1a).

Figure 4-1. Scatter plots of the calculated and measured currents at (a) AWAC\#1 and (b) AWAC\#2 from 21 November to 25 December 2019.

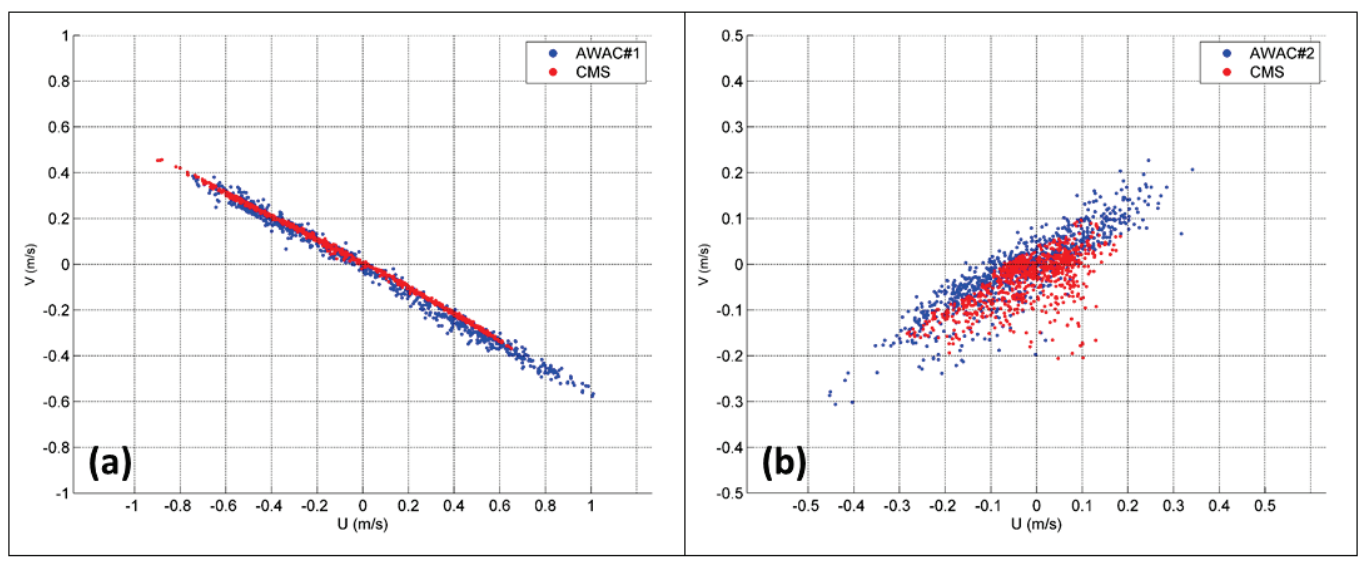

The positive $\mathrm{U}$ and $\mathrm{V}$ values at AWAC\#2 indicate water flowing along the shoreline in the northeast direction. Relative to north, both the calculated and measured principal current axes have an angle of approximately $60^{\circ}$. At this open ocean site, although still small, the cross-shore current is relatively strong comparing to longshore current component. The scatter plot shows similar distribution pattern of currents (Figure 4-1b).

The velocity scatter figure clearly displays the principal current directions, along the river channel at AWAC\#1, and parallel to the coastline at AWAC\#2. Both the calculated and the measured currents are rotated to this direction for model current calibration/validation at these two locations. 
The current comparisons in the principal directions between the CMS results and the measurements are shown in Figure 4-2. At AWAC\#1, the tidal signal is predominant with the measured currents ranging from -1.0 (ebb current) to $0.8 \mathrm{~m} / \mathrm{s}(-3.28$ to $2.62 \mathrm{ft} / \mathrm{s}$ ) (flood current) in the alongchannel direction. The asymmetry in the tidal current indicates that the estuarine system is ebb dominated. The CMS calculated a consistent flood current $(0.8-1.0 \mathrm{~m} / \mathrm{s}(2.62-3.28 \mathrm{ft} / \mathrm{s}))$ but underpredicted the ebb current $(-0.7 \mathrm{~m} / \mathrm{s})(-2.3 \mathrm{ft} / \mathrm{s})$ (Figure 4-2a).

Figure 4-2. Current comparisons between the measurements and the CMS calculations at (a) AWAC\#1 and (b) AWAC\#2 from 21 November to 25 December 2019).

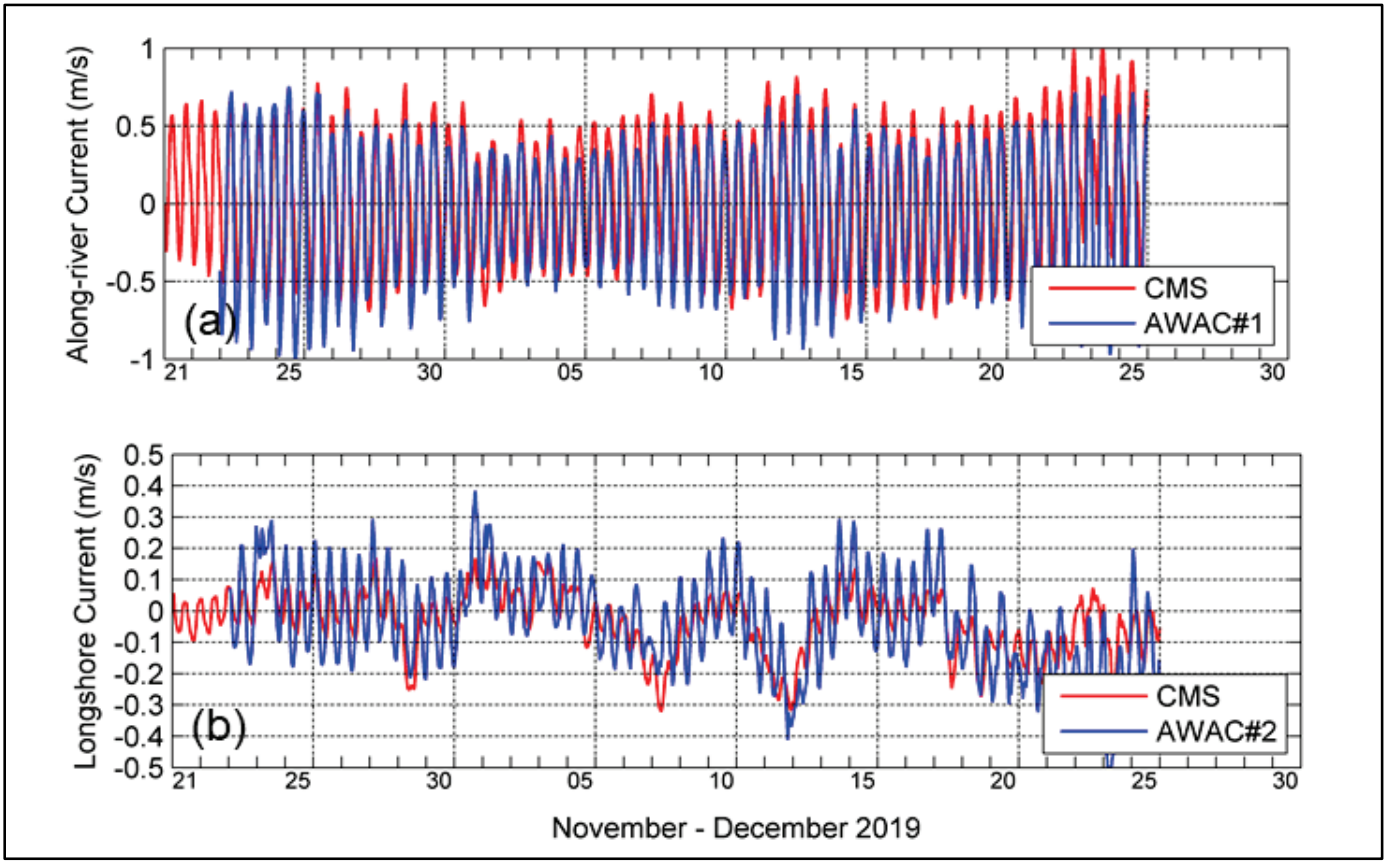

At AWAC\#2, tidal currents were clearly overlapping with low-frequency currents during the simulation period, which was mostly due to wind effect. Using the wind at the nearby NOAA buoy to drive the model, the low-frequency longshore current variations were reproduced very well. The calculated tidal current phases matched well with the measurements, but the tidal current speeds were underestimated (Figure 4-2b).

Table 4-1 and Table 4-2 list the goodness of fit statistics between the measurements and the model calculations at AWAC\#1 and AWAC\#2, respectively. Overall, the calculated principal currents are in good agreement with the measured currents. At AWAC\#1, the RMSE is 0.29 $\mathrm{m} / \mathrm{s}(0.95 \mathrm{ft} / \mathrm{s})$, the NRMSE is $16.3 \%$, and the correlation coefficient $\mathrm{R}$ 
between the model and data is 0.8 . At AWAC\#2, the RMSE is $0.11 \mathrm{~m} / \mathrm{s}$ $(0.36 \mathrm{ft} / \mathrm{s})$, the NRMSE is $14.3 \%$, and the correlation coefficient $\mathrm{R}$ between the model and data is 0.66 . Major discrepancies between the calculated results and measured data could be due to the limited spatial coverage of wind and wave data, and accuracy and resolution of wetland topography and bathymetry.

Table 4-1. Goodness of fit statistics between the AWAC\#1 measurements and the CMS calculations from 21 November to 25 December 2019.

\begin{tabular}{|l|l|l|l|}
\hline \multirow{2}{*}{ Variable } & \multicolumn{3}{c|}{ Goodness of Fit Statistics } \\
\cline { 2 - 4 } & $\mathbf{R}$ & RMSE & NRMSE (\%) \\
\hline $\begin{array}{l}\text { Water Surface } \\
\text { Elevation }(\mathrm{m})\end{array}$ & 0.963 & 0.169 & 6.8 \\
\hline $\begin{array}{l}\text { Along-channel } \\
\text { Current }(\mathrm{m} / \mathrm{s})\end{array}$ & 0.804 & 0.294 & 16.3 \\
\hline
\end{tabular}

Table 4-2. Goodness of fit statistics between the AWAC\#2 measurements and the CMS calculations from 21 November to 25 December 2019.

\begin{tabular}{|l|l|l|l|}
\hline \multirow{2}{*}{ Variable } & \multicolumn{3}{|c|}{ Goodness of Fit Statistics } \\
\cline { 2 - 4 } & R & RMSE & NRMSE (\%) \\
\hline $\begin{array}{l}\text { Water Surface } \\
\text { Elevation (m) }\end{array}$ & 0.969 & 0.151 & 6.0 \\
\hline $\begin{array}{l}\text { Longshore Current } \\
(\mathrm{m} / \mathrm{s})\end{array}$ & 0.663 & 0.114 & 14.3 \\
\hline $\begin{array}{l}\text { Significant Wave Height } \\
(\mathrm{m})\end{array}$ & 0.858 & 0.329 & 12.2 \\
\hline Peak Wave Period $(\mathrm{s})$ & 0.506 & 2.052 & 13.3 \\
\hline
\end{tabular}

Figure 4-3 shows the calculated and measured WSEs at the AWAC gauges. Both the measurements and calculations show that the spring tidal range is close to $2.5 \mathrm{~m}(8.2 \mathrm{ft})$ and the neap tidal range is approximately $1.5 \mathrm{~m}$ (4.92 ft). Visual inspection indicates that the CMS results reproduce the tidal signals displayed in the river channel and the open coastal area very well. The RMSEs at the two gauge locations are approximately $0.15 \mathrm{~m}$ (0.49 ft) and the NRMSE 6.0\%. The correlation coefficient R between the model and data is greater than 0.96 (Table 4-1 and Table 4-2). 
Figure 4-3. Comparisons of WSE between the measurements and the CMS calculations at (a) AWAC\#1 and (b) AWAC\#2 from 21 November to 25 December 2019.

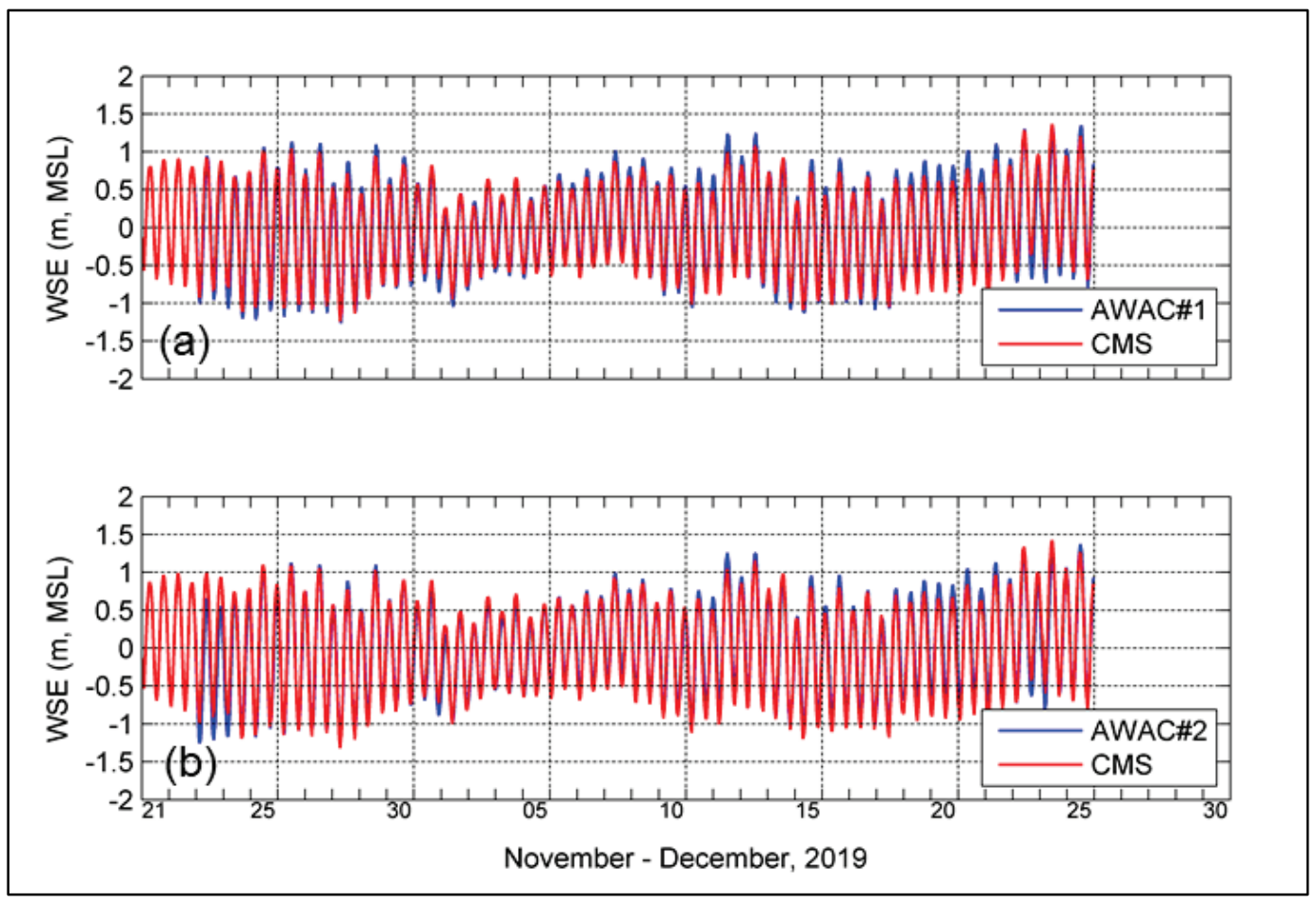

AWAC\# 1 was located in the river channel, and wave impact was insignificant. Average significant wave height over the simulation period is less than $0.1 \mathrm{~m}(0.33 \mathrm{ft})$. Therefore, only the wave parameters at AWAC\# 2 were used to calibrate/validate the CMS. The comparisons of the measured and calculated wave parameters are shown in Figure 4-4. The measured and calculated mean significant wave heights at this location are 0.70 and $0.85 \mathrm{~m}(2.3$ and $2.79 \mathrm{ft})$, respectively. There were a few occasions when the measured wave heights were close or greater than $1.5 \mathrm{~m}$ (4.92 ft) during the 35-day period. While the calculated wave heights show corresponding peaks, the values were generally overestimated. When examining wind conditions in Figure 4-4, it can be seen that those high wave conditions are well correlated with weather (storm) events.

Both the measured and calculated mean wave period is $8.2 \mathrm{~s}$, and the predominant wave direction is southeast. The correlation coefficients are 0.86 and 0.51 for wave height and wave period, respectively. The RMSE and the NRMSE are $0.33 \mathrm{~m}$ (1.08 ft) and 12.2\% for wave height, $2.05 \mathrm{~s}$ and 13.3\% for wave period, respectively (Table 4-2). The sensitivity tests on wave transformation show that the calculated wave parameters are closely 
associated with the specifications of boundary conditions. Close to this study area, the only offshore buoy that provides directional wave spectra is NOAA Buoy \#41004. Other options are to utilize wave parameter generated spectra from nearby sites of hindcast products, such USACE WIS and NOAA Wave Watch III (WWIII). Data limitation might hinder the model performance in reproducing better wave simulation results. Note in Figure 4-4 that relatively large discrepancies between measured and calculated wave periods occur when wave heights are usually smaller than $0.5 \mathrm{~m}(1.64 \mathrm{ft})$ and the noise exists in the measuremens of wave direction. Therefore, the model computational error is also due to instrument accuracy and stability.

Figure 4-4. Comparisons of wave parameters between the measurements and the CMS calculations at AWAC\#2 from 21 November to 25 December 2019. (a) Significant wave height, (b) Peak wave period, and (c) Mean wave direction.

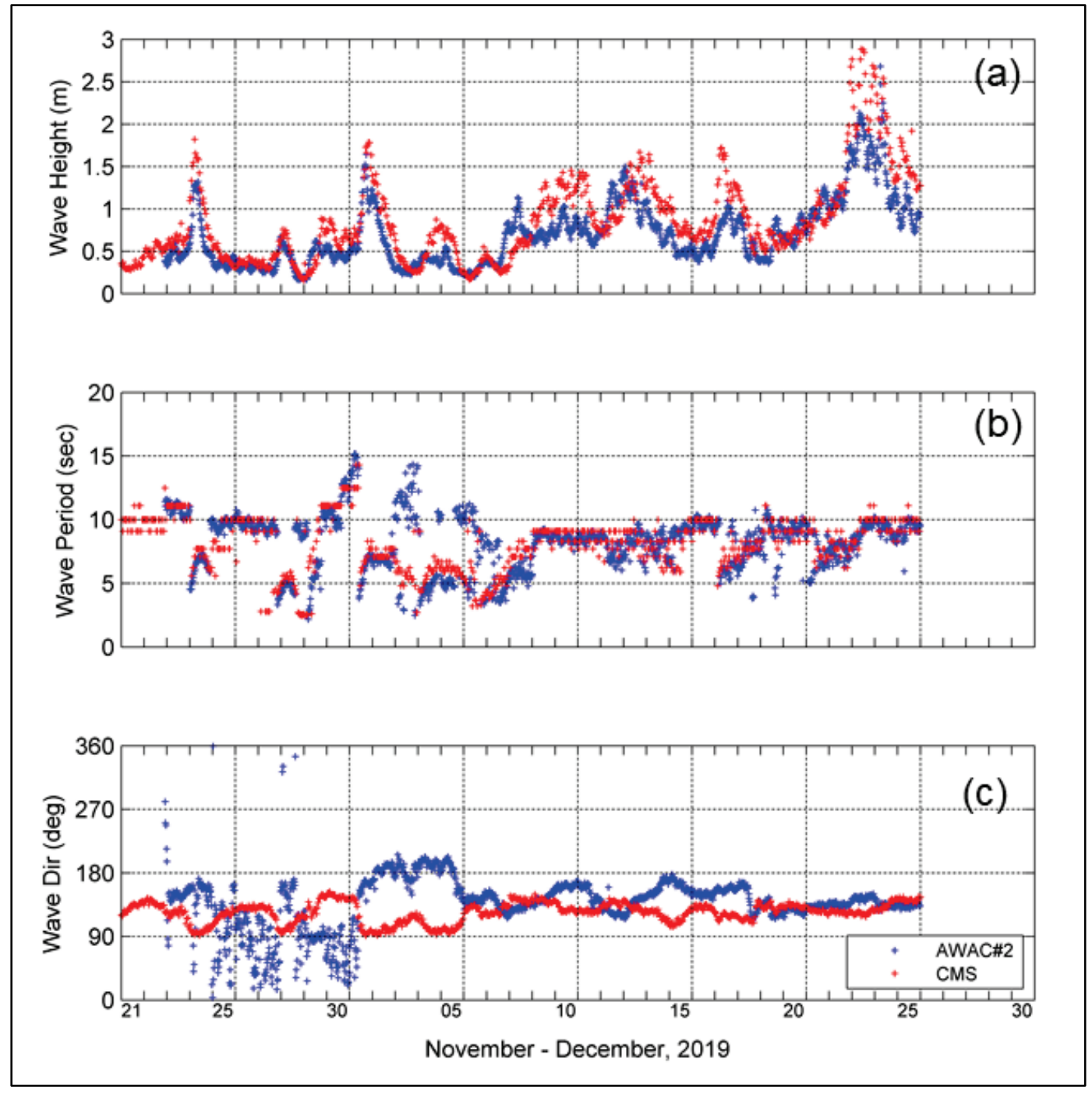




\subsection{Hurricane Hugo}

\subsubsection{Waves}

As shown in Figure 3-7, Hurricane Hugo brought high waves up to $6.0 \mathrm{~m}$ $(19.69 \mathrm{ft})$ to the coast. The maximum wave heights in the study area occurred on 22 September 1989 at 05:00 (GMT). Spatial distribution of significant wave heights and wave directions is shown in Figure 4-5, and the calculated results correspond to the peak wave period of the storm. The figure clearly displays that hurricane waves propagated from south-southeast and refracted approaching to shoreline. Significant wave refraction can be seen around Kiawah Island and the Stono Inlet Throat borrow area because of the protruding shoreline of the island and sudden water depth decrease within the borrow area. Significant wave heights have a value between 5.0 and $5.6 \mathrm{~m} \mathrm{(16.41} \mathrm{and} 18.37 \mathrm{ft})$ in the offshore area. Close to shoreline, wave heights are reduced but still have a value between 2.2 and $3.0 \mathrm{~m}$ (7.21 and $9.84 \mathrm{ft}$ ) due to water depth increase related to hurricane-induced storm surge. Wave heights are further reduced to $0.5-1.0 \mathrm{~m}(1.64-3.28 \mathrm{ft})$ at the confluent region of Stono, Folly Rivers, and ocean, and are smaller than $0.3 \mathrm{~m}$ (0.98 ft) into the rivers.

Figure 4-5. Calculated maximum significant wave heights during the Hurricane Hugo passage on 22 September 1989 at 05:00 (GMT).

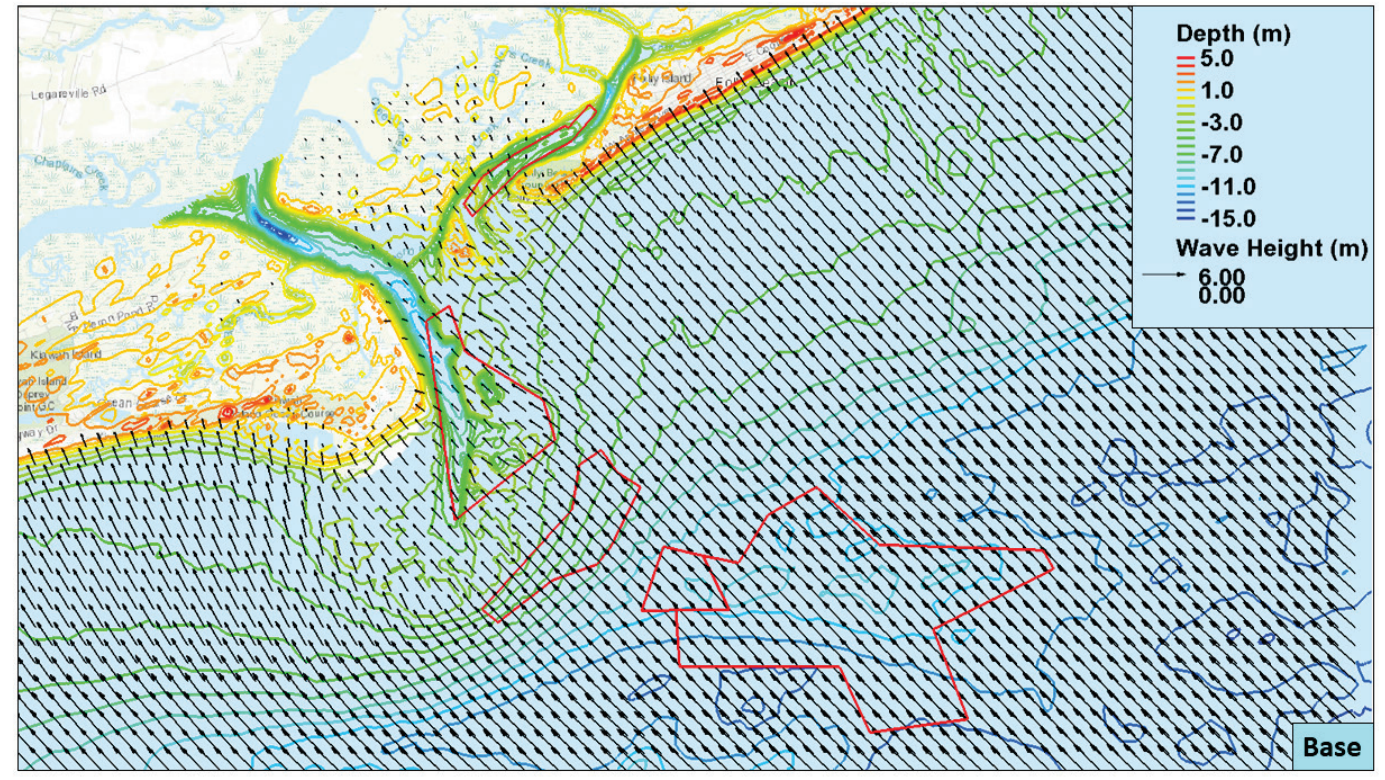


Significant wave heights before (base) and after (alternatives) dredge are examined within the five sand borrow areas in Figure 4-6 to Figure 4-10, respectively. Changes between the base and alternative cases can hardly be visualized from the figures. Detail value comparisons are listed in Table 4-3.

Figure 4-6. Comparison of significant wave heights between (a) base case and (b) Alternative 1 within the Folly River borrow area (the red polygon) during the Hurricane Hugo Passage on 22 September 1989 at 05:00 (GMT).

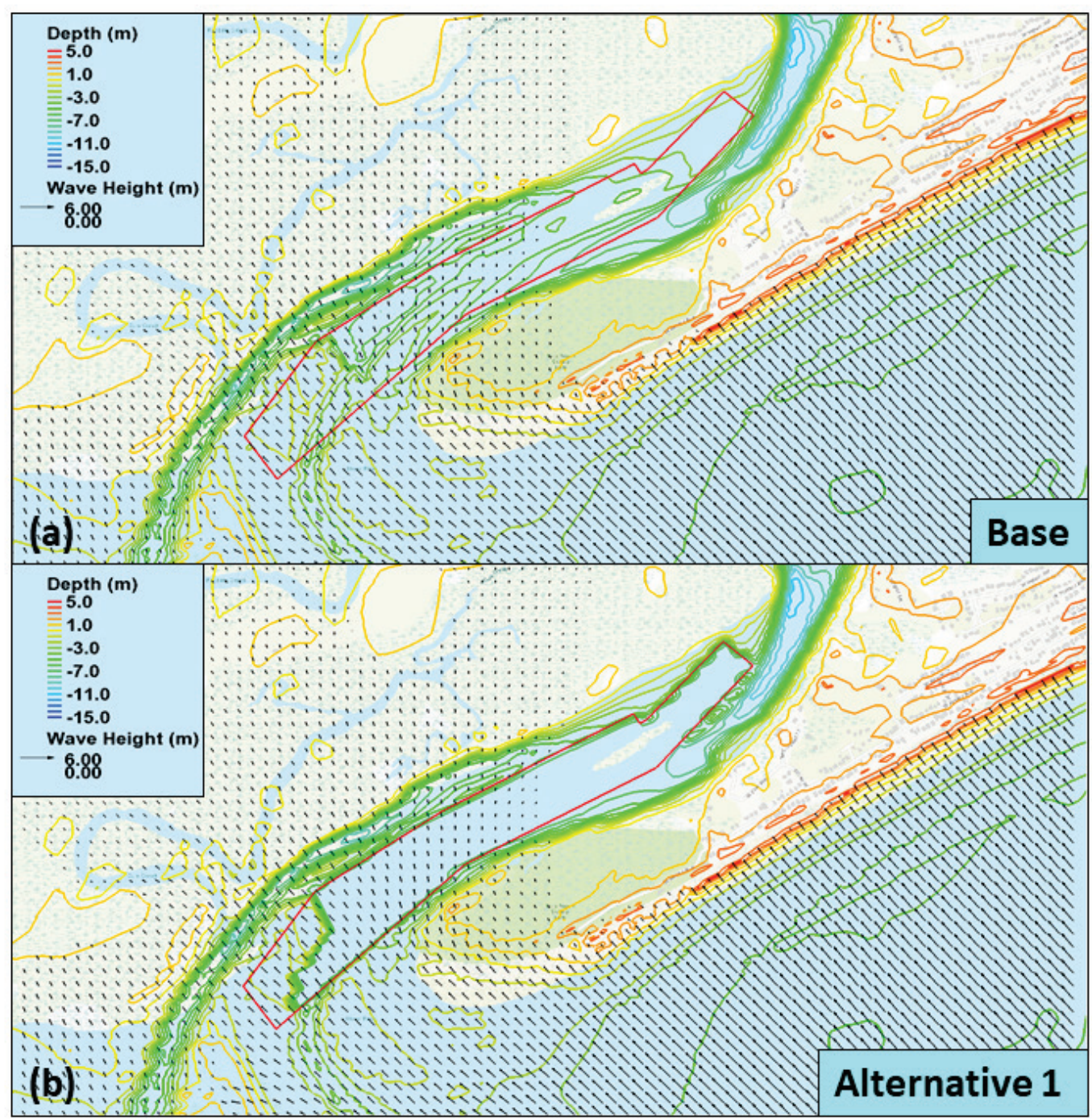


Figure 4-7. Comparison of significant wave heights between (a) base case and (b) Alternative 2 within the Stono Inlet Throat borrow area (the red polygon) during the Hurricane Hugo Passage on 22 September 1989 at 05:00 (GMT).

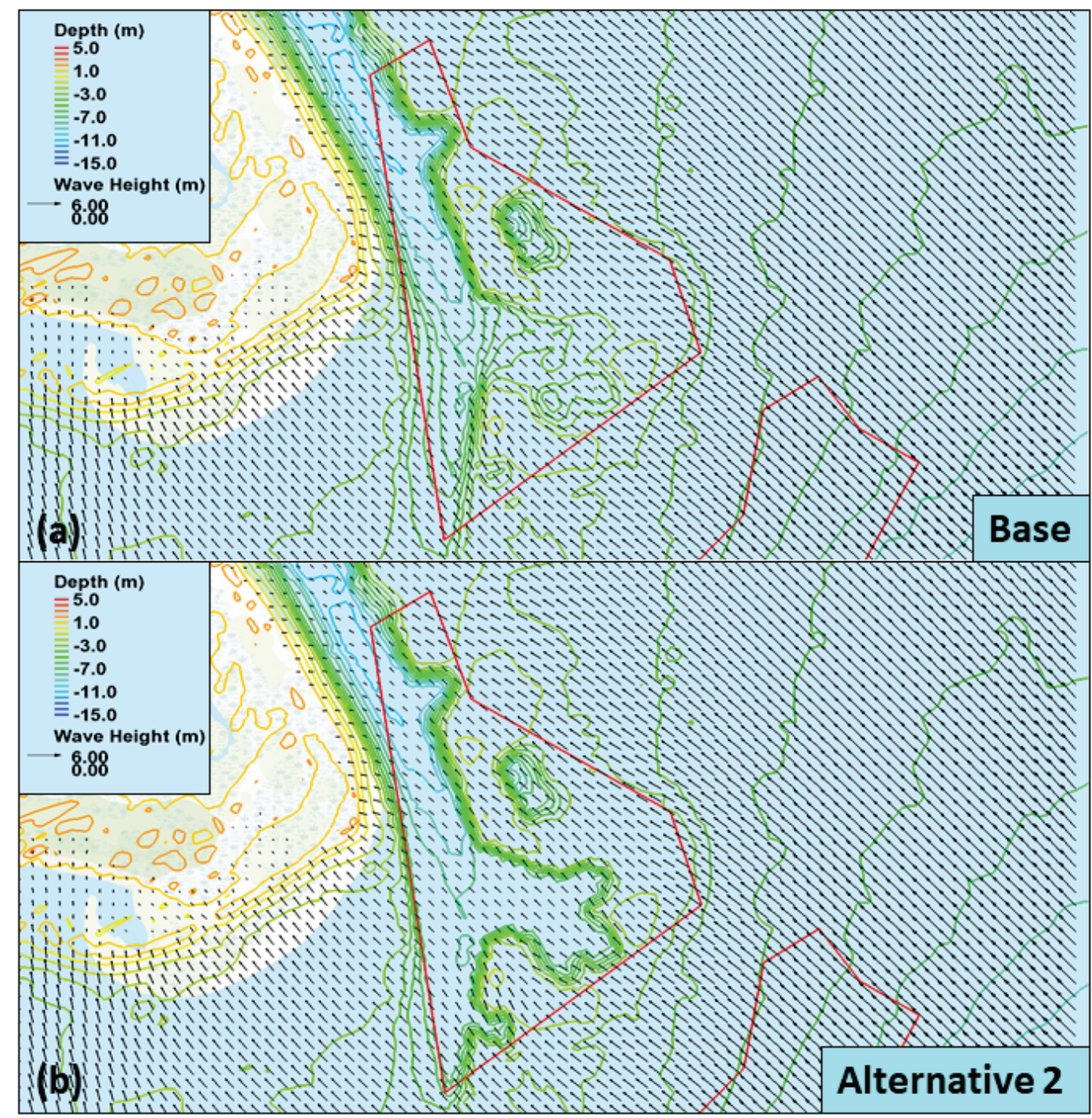


Figure 4-8. Comparison of significant wave heights between (a) base case and (b) Alternative 3 within the Stono Ebb Shoal 1 borrow area (the red polygon) during the Hurricane Hugo Passage on 22 September 1989 at 05:00 (GMT).

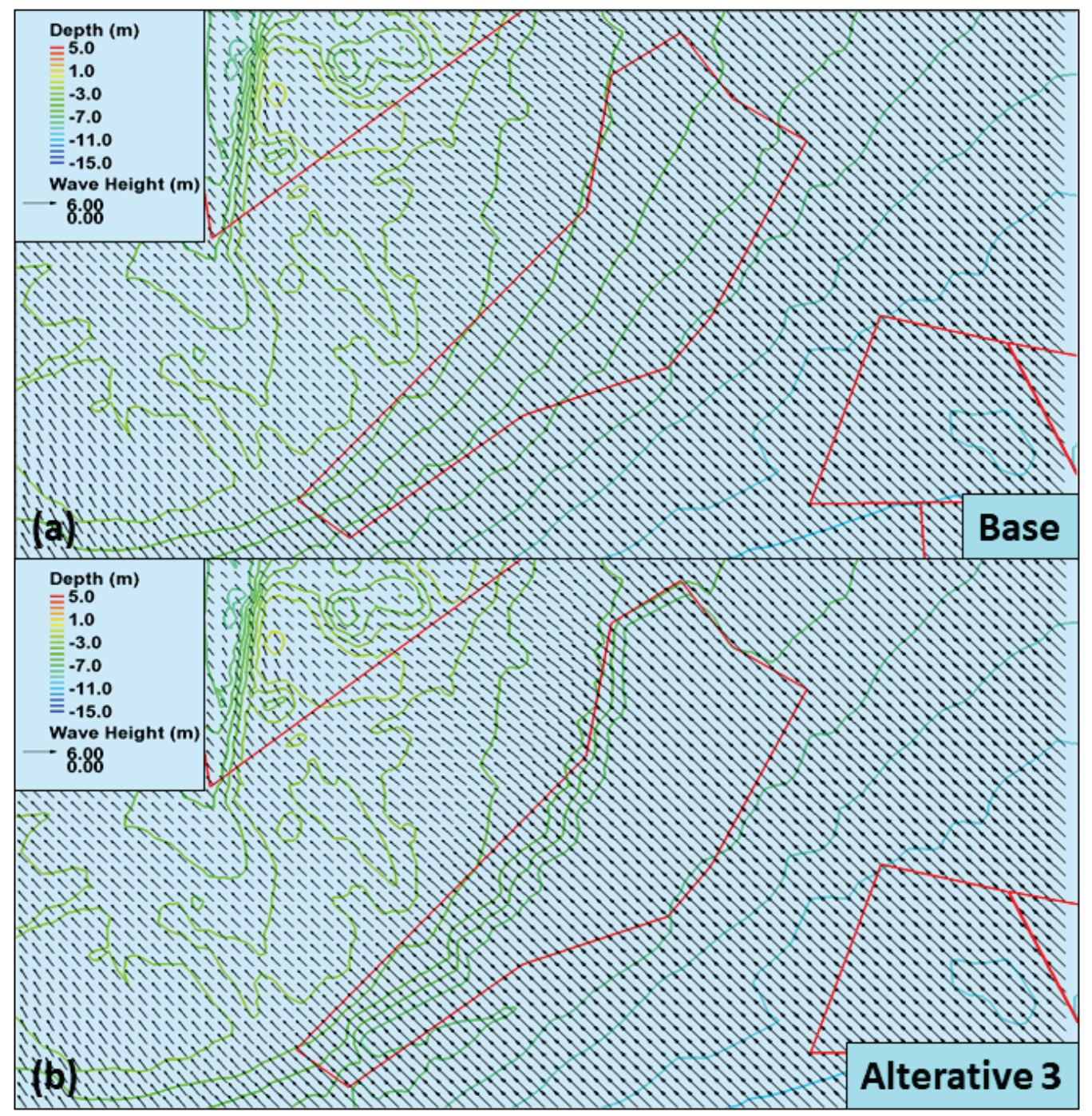


Figure 4-9. Comparison of significant wave heights between (a) base case and (b) Alternative 4 within the Stono Ebb Shoal 2 borrow area (the red polygon) during the Hurricane Hugo Passage on 22 September 1989 at 05:00 (GMT).

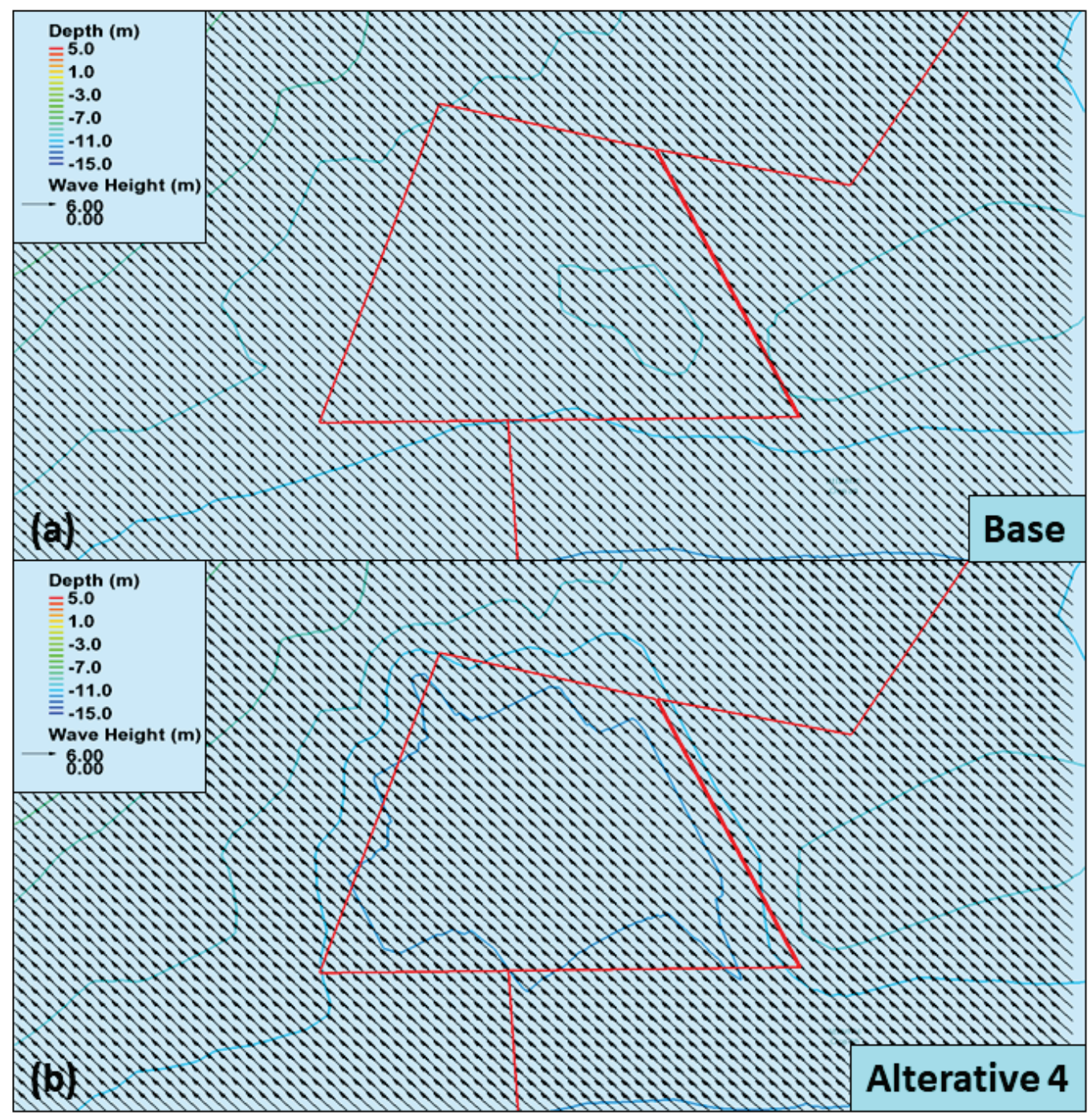


Figure 4-10. Comparison of significant wave heights between (a) base case and (b) Alternative 5 within the Stono Inlet borrow area (the red polygon) during the Hurricane Hugo Passage on 22 September 1989 at 05:00 (GMT).

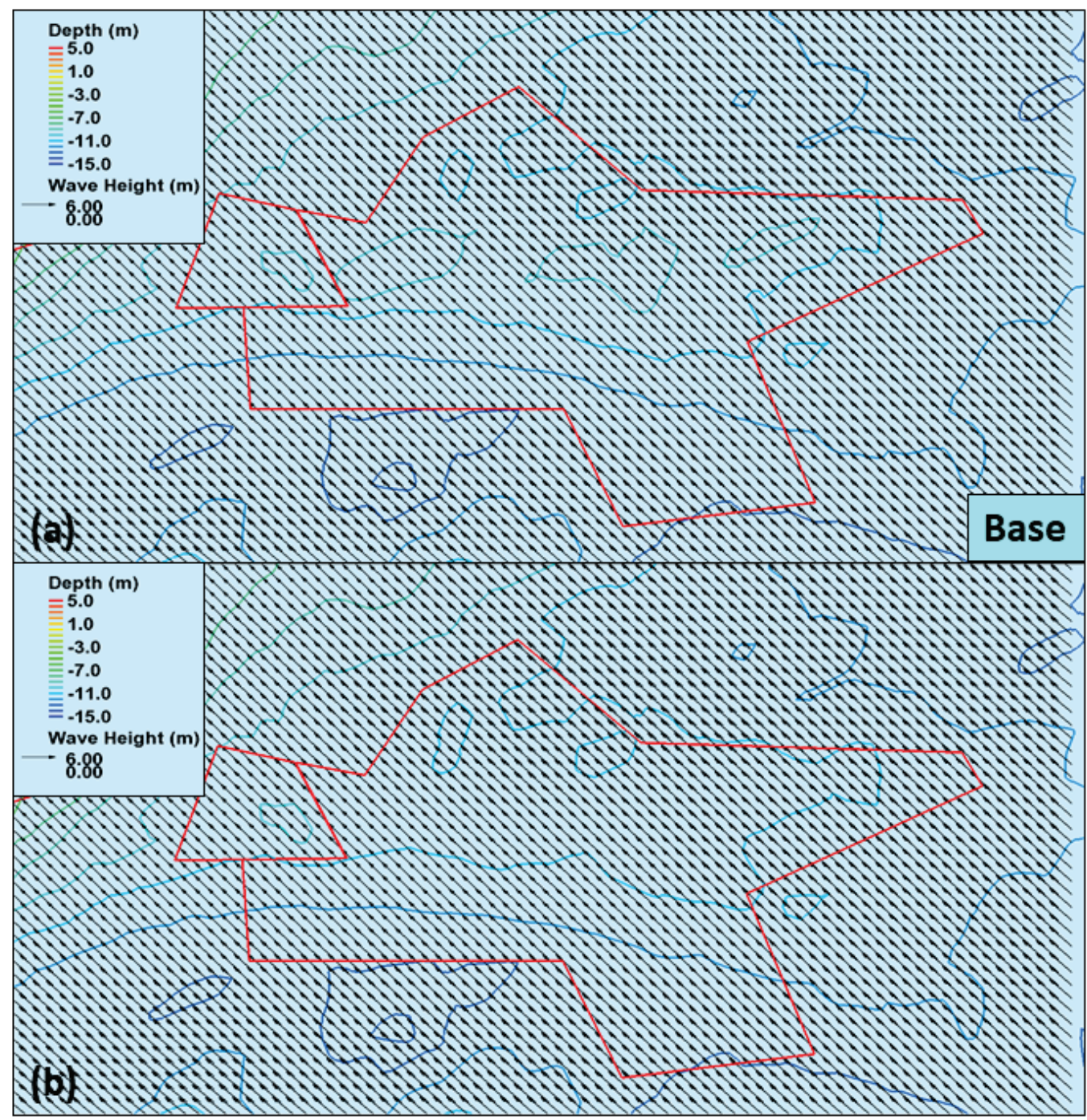

Table 4-3. Comparisons of significant wave heights between the base case (before sand dredge) and alternatives (after sand dredge) in borrow areas during Hurricane Hugo.

\begin{tabular}{|c|c|c|c|c|c|c|c|c|c|c|}
\hline \multirow{2}{*}{$\begin{array}{l}\text { Borrow Area } \\
\text { Scenario }\end{array}$} & \multicolumn{2}{|c|}{ Folly River } & \multicolumn{2}{|c|}{$\begin{array}{l}\text { Stono Inlet } \\
\text { Throat (I) }\end{array}$} & \multicolumn{2}{|c|}{$\begin{array}{l}\text { Stono Ebb Shoal } \\
1(J)\end{array}$} & \multicolumn{2}{|c|}{$\begin{array}{l}\text { Stono Ebb Shoal } \\
2(\mathrm{~K})\end{array}$} & \multicolumn{2}{|c|}{ Stono Inlet (E) } \\
\hline & Base & Alt 1 & Base & Alt 2 & Base & Alt 3 & Base & Alt 4 & Base & Alt 5 \\
\hline $\begin{array}{l}\text { Significant Wave } \\
\text { Height }(m)\end{array}$ & $1.0-1.6$ & 1.3-1.7 & $1.5-2.8$ & $1.4-2.6$ & 3.8 & 4.4 & 5.1-5.2 & $5.2-5.3$ & $5.1-5.5$ & 5.1-5.5 \\
\hline
\end{tabular}


The Folly River borrow area has an original average depth of $2.56 \mathrm{~m}$ $(8.53 \mathrm{ft})$ relative to MSL. To obtain 2.5 MCY (1.91 M m3) of sand materials

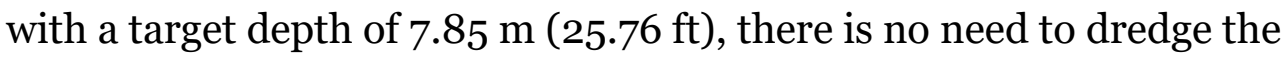
entire area, and therefore no sand materials are dredged at the southwest corner of the area for the Alternative 1 simulation (Figure 1-1 and Figure 3-11). Corresponding to this setup, Figure 4-6 does not show much change in significant wave heights before (base) and after (Alternative 1) the dredge over the southwest portion but does show slightly higher waves propagating over the dredged portion of borrow area.

To dredge to a target depth of $7.55 \mathrm{~m}(24.77 \mathrm{ft})$ in the Stono Inlet Throat borrow area (Alternative 2), only a small portion of the area off the Folly Rive Navigation Channel needs to be dredged (Figure 1-1 and Figure 3-12). Generally, significant wave heights were larger in the base simulation than those after dredging. But the east part of the borrow area was not dredged and relatively shallow, over which significant wave heights were larger after dredging than those in the base simulation due to stronger wave refraction related to deepening on the west side of the area (Figure 4-7).

In the Stono Ebb Shoal 1 borrow area, the average water depth is $5.94 \mathrm{~m}$ $(19.49 \mathrm{ft})$, and the targeted dredge depth is $7.55 \mathrm{~m}(24.77 \mathrm{ft})$. After sand removal, higher offshore waves propagated in the area with less dissipation (Figure 4-8). Significant wave heights were increased by more than $0.5 \mathrm{~m}(1.64 \mathrm{ft})$ in the actual borrow area (Figure 1-1 and Table 4-3).

The Stono Ebb Shoal 2 borrow area has an original water depth of $10.28 \mathrm{~m}$ (33.73 ft). To obtain 2.5 MCY of sand materials, the target dredge depth was set to $12.0 \mathrm{~m}(39.37 \mathrm{ft})$. The large water depths before and after sand removal did not affect significant wave heights traveling over the area (Figure 4-9 and Table 4-3).

Similar to the Stono Ebb Shoal 2 borrow area, the Stono Inlet borrow area has a large base water depth of $11.19 \mathrm{~m}(36.71 \mathrm{ft})$. Due to the size of the area, it does not require much adjustment in water depth. After sand removal, the average water depth of the area was increased only to $11.36 \mathrm{~m}$ $(37.27 \mathrm{ft})$. Therefore, there was no significant impact on wave propagation due to water depth changes over the area (Figure 4-10 and Table 4-3). 


\subsubsection{Current}

During the passage of Hurricane Hugo, storm surge coinciding with flood tide generated extreme currents in the study area on 22 September 1989 at 03:00 (GMT). Spatial distribution of the currents is shown in Figure 4-11, which illustrates offshore and nearshore current patterns around the Stono Inlet estuarine system. The strongest currents with a speed close to $3.0 \mathrm{~m} / \mathrm{s}(9.84 \mathrm{ft} / \mathrm{s})$ occurred in the Stono River channel. The nearshore zone in front of Folly Beach shows strong longshore current flowing from northeast to southwest. The longshore flow had a current speed between 1.0 and $1.5 \mathrm{~m}$ (3.28 and $4.92 \mathrm{ft} / \mathrm{s})$ but intensified with a speed of more than $2.0 \mathrm{~m} / \mathrm{s}$ when making a turn towards northwest into the Folly River channel area around the southwest corner of Folly Island. In the offshore area, the current field shows a general flow direction towards land with a small current speed of $0.3 \mathrm{~m} / \mathrm{s}(0.98 \mathrm{ft} / \mathrm{s})$.

Figure 4-11. Calculated currents during the Hurricane Hugo passage on 22 September 1989 at 03:00 (GMT). Polygons indicate the five sand borrow areas.

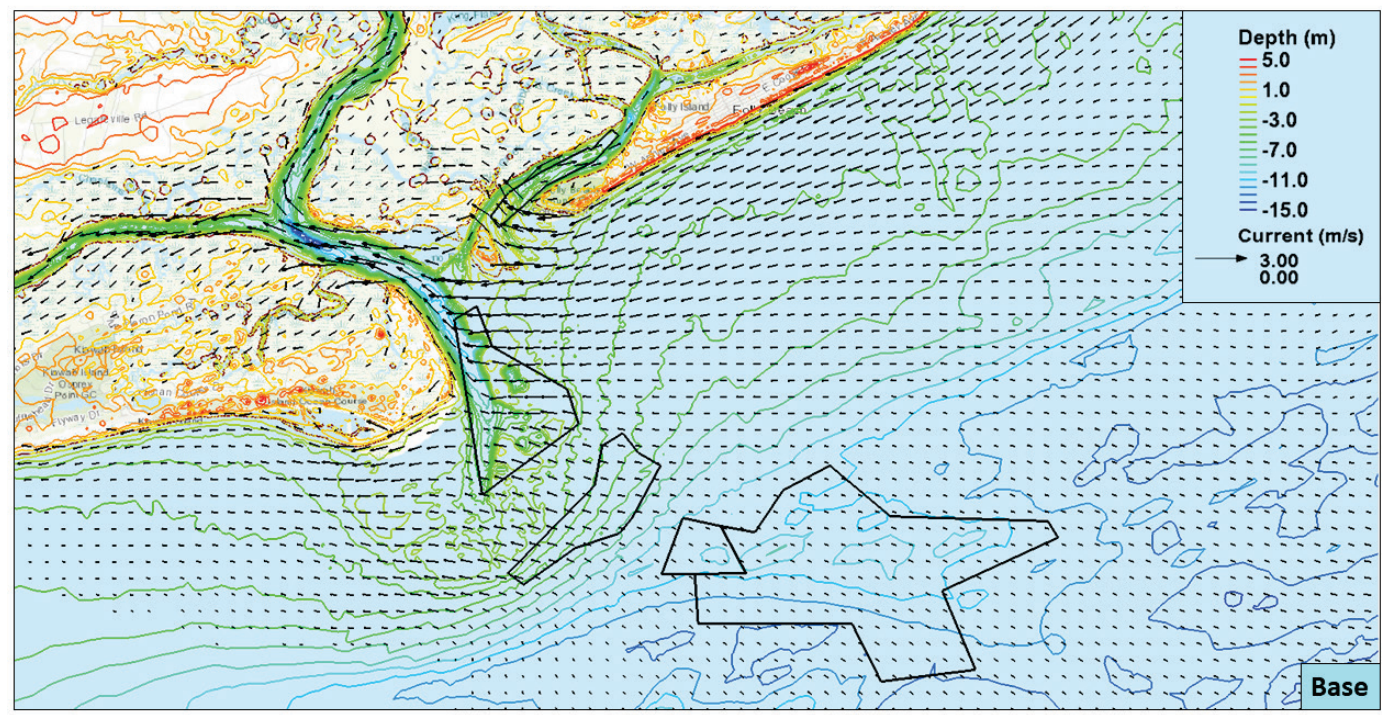

Impact on current changes due to sand removal from each of the borrow areas is evaluated in Figure 4-12 to Figure 4-16, respectively. Detail value comparisons are listed in Table 4-4. 
Figure 4-12. Comparison of currents between (a) base case and (b) Alternative 1 within the Folly River borrow area (the polygon) during the Hurricane Hugo Passage on 22 September 1989 at 03:00 (GMT).

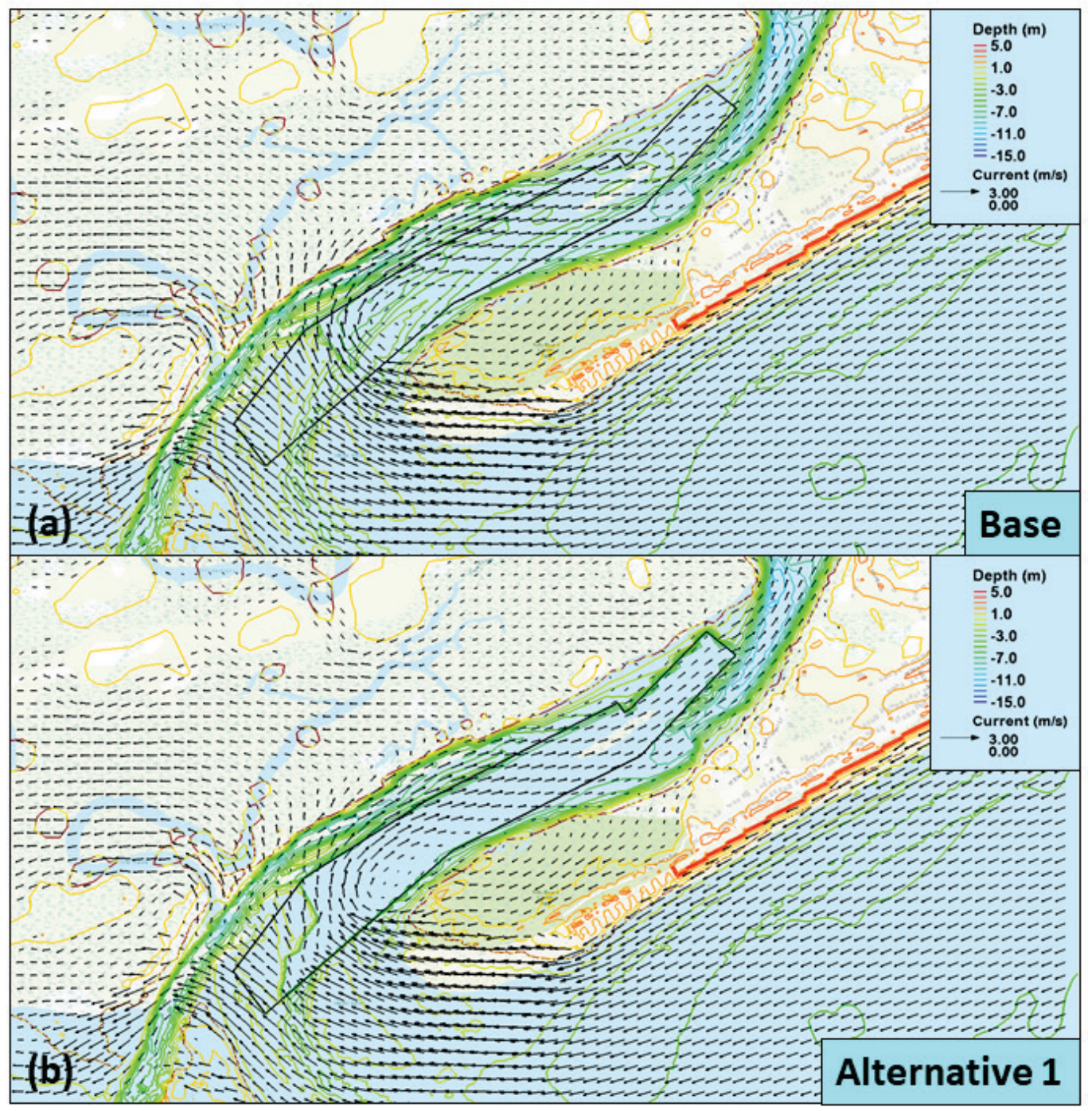


Figure 4-13. Comparison of currents between (a) base case and (b) Alternative 2 within the Stono Inlet Throat borrow area (the polygon in the center) during the Hurricane Hugo Passage on 22 September 1989 at 03:00 (GMT).

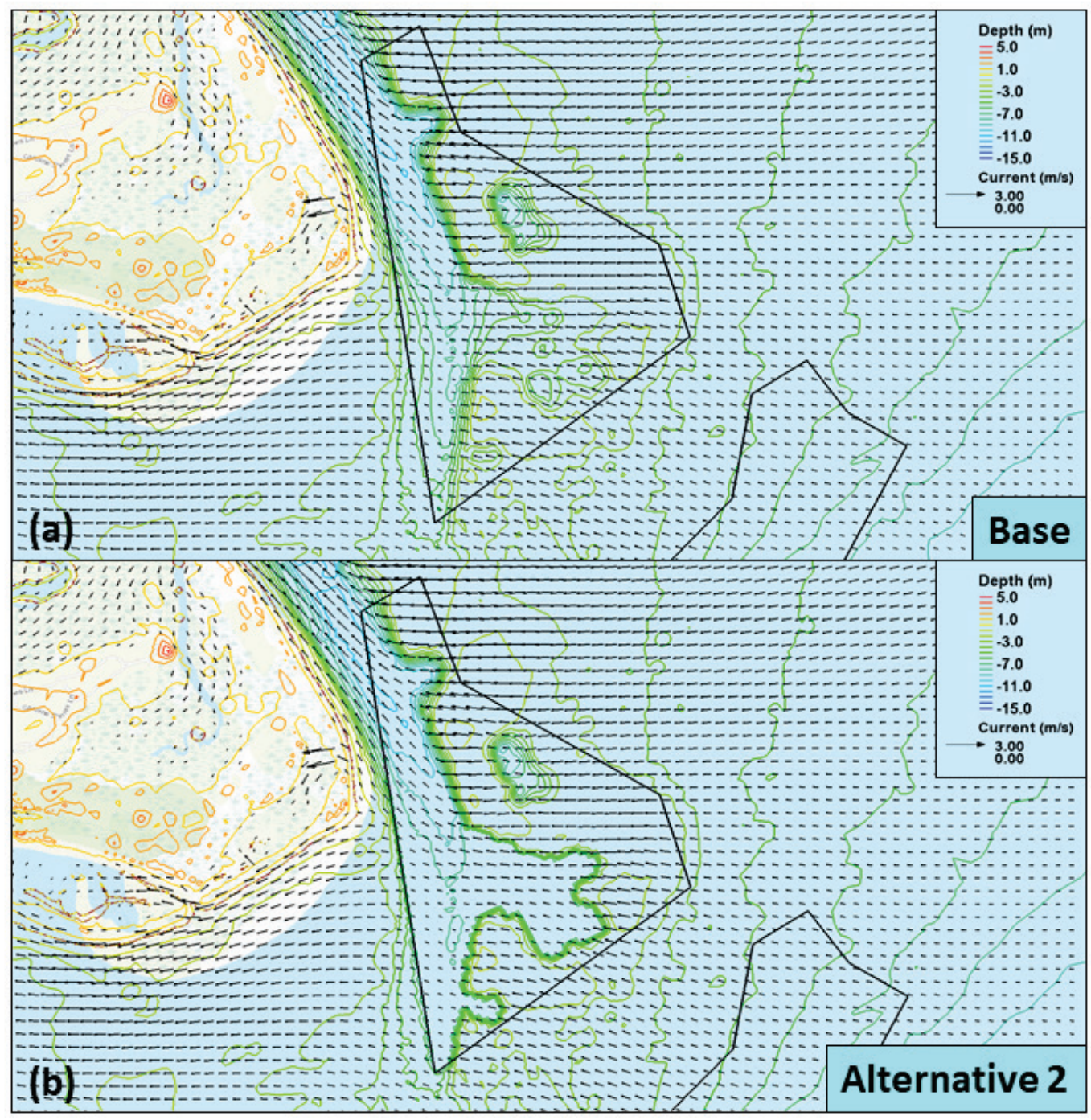


Figure 4-14. Comparison of currents between (a) base case and (b) Alternative 3 within the Stono Ebb Shoal 1 borrow area (the polygon in the center) during the Hurricane Hugo Passage on 22 September 1989 at 03:00 (GMT).

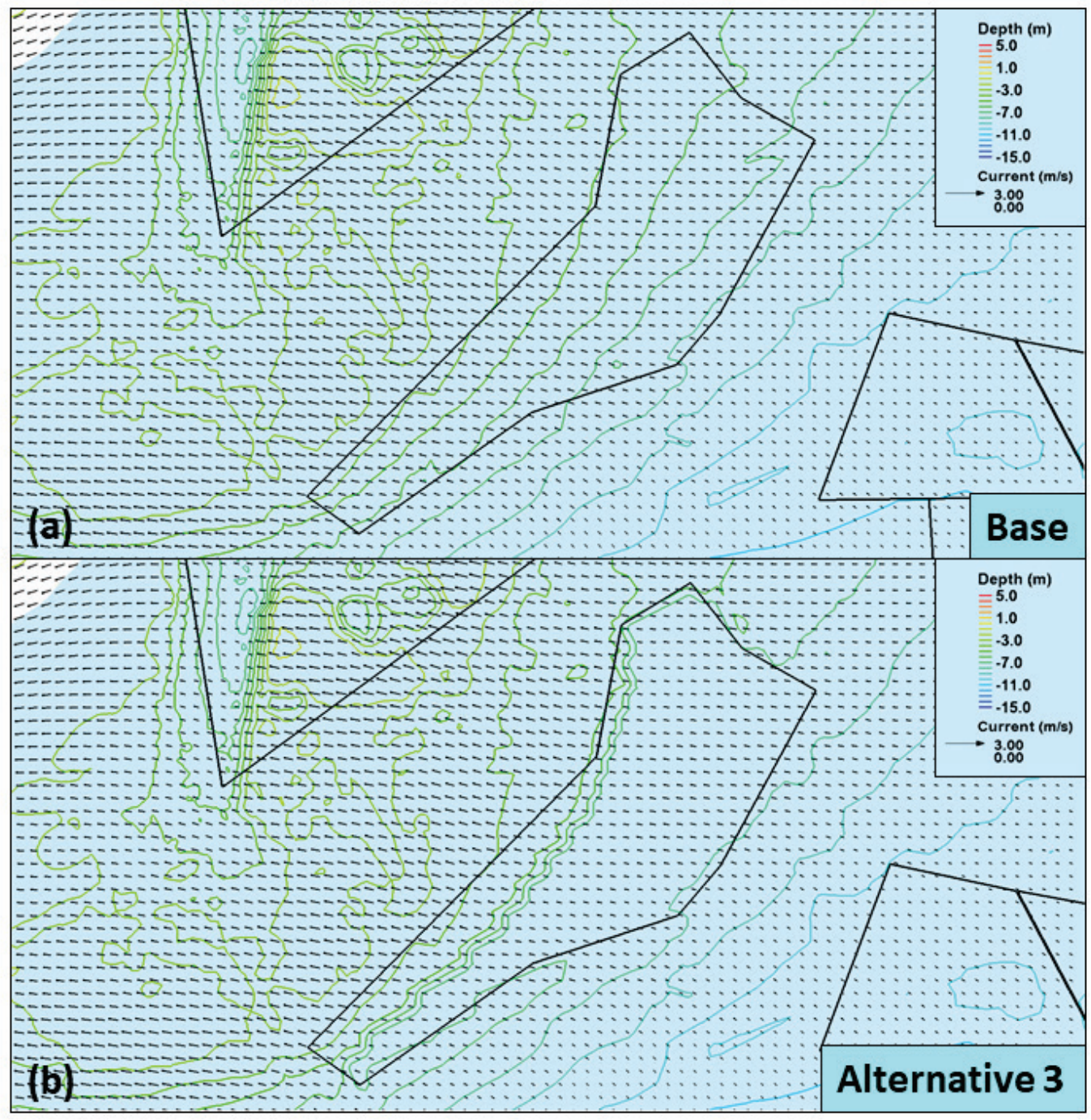


Figure 4-15. Comparison of currents between (a) base case and (b) Alternative 4 within the Stono Ebb Shoal 2 borrow area (the polygon in the center) during the Hurricane Hugo Passage on 22 September 1989 at 03:00 (GMT).

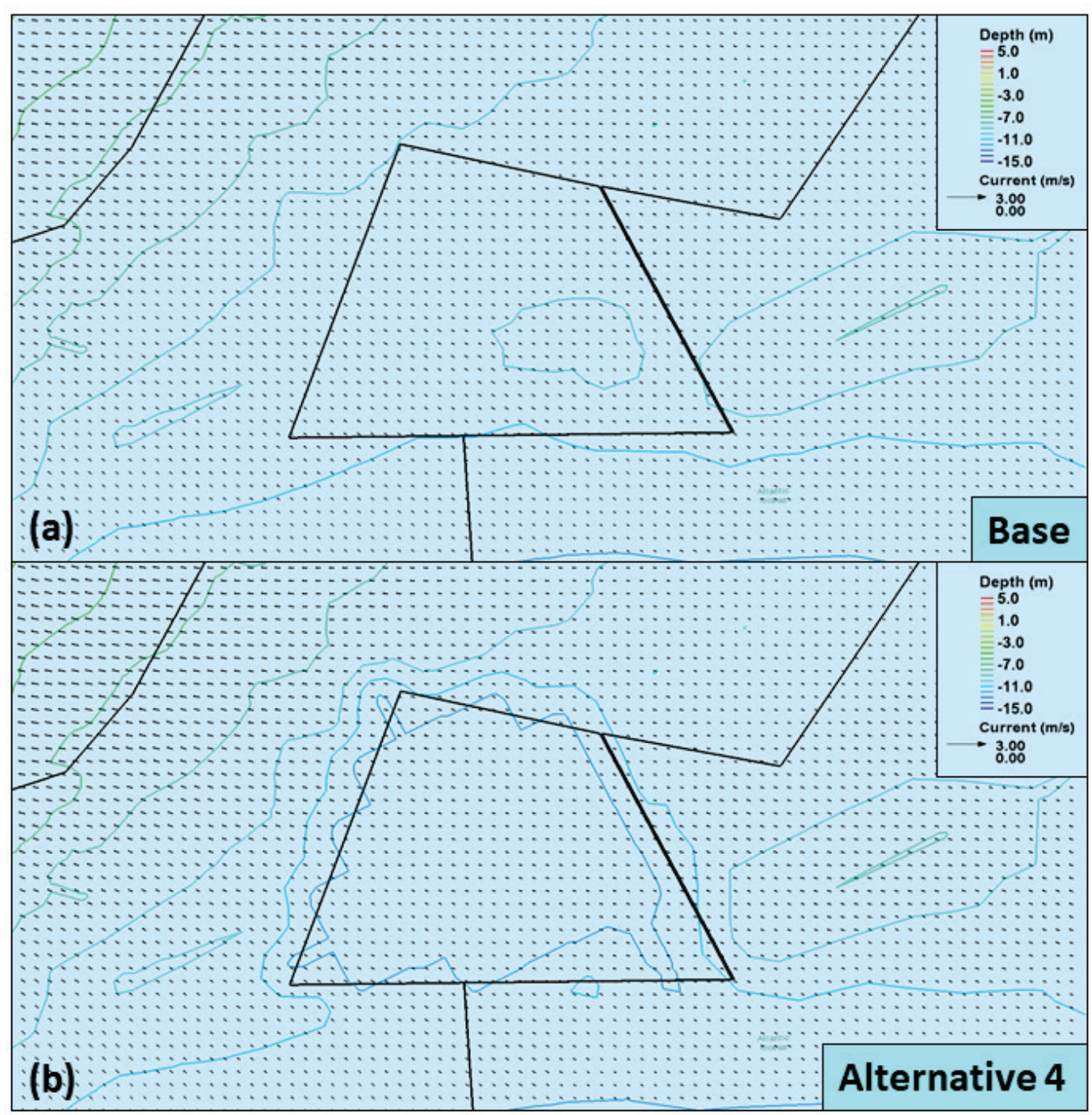


Figure 4-16. Comparison of currents between (a) base case and (b) Alternative 5 within the Stono Inlet borrow area (the bigger polygon in the center) during the Hurricane Hugo Passage on 22 September 1989 at 03:00 (GMT).

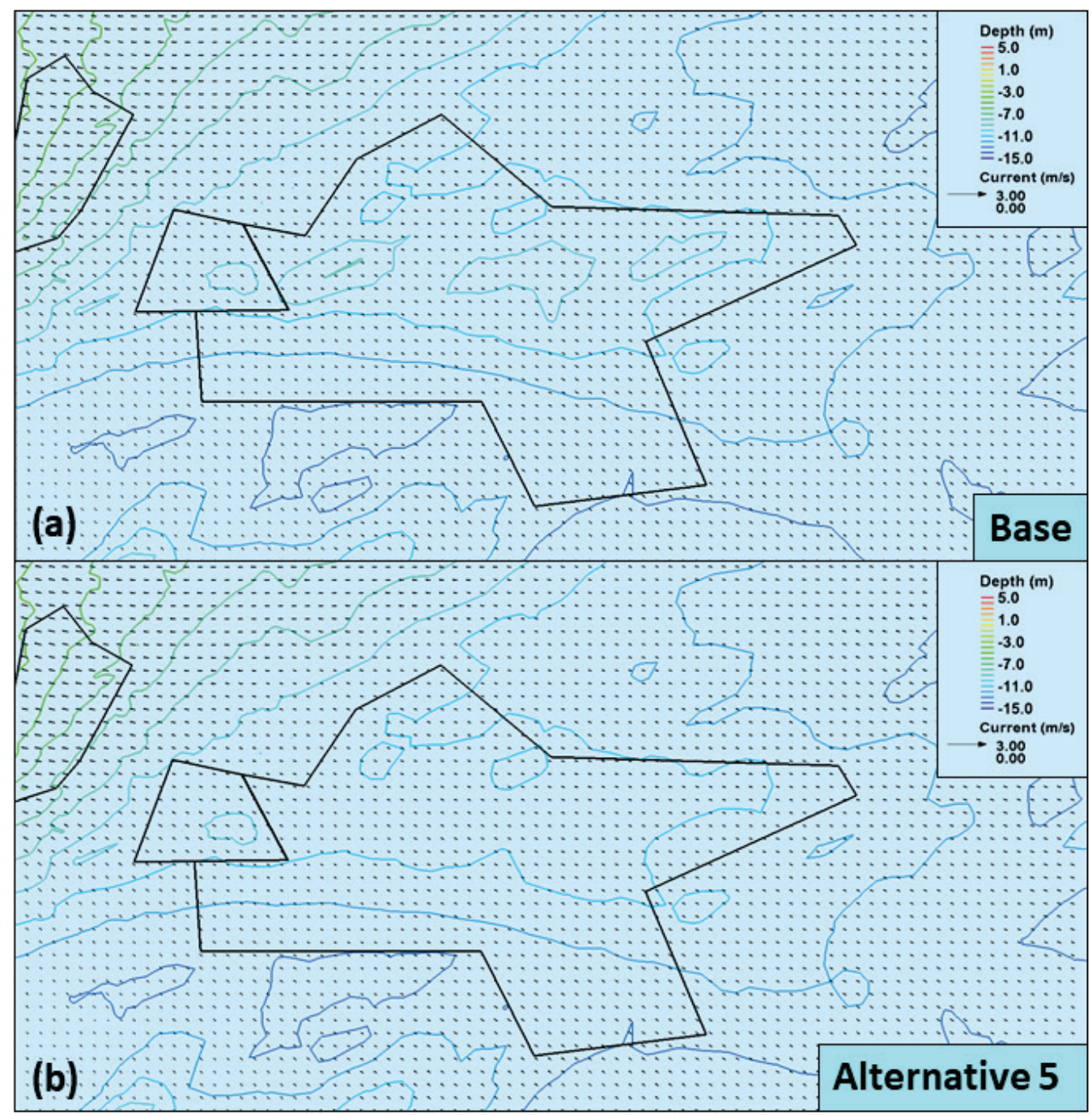

Table 4-4. Comparisons of currents between the base case (before sand dredge) and alternatives (after sand dredge) in borrow areas during Hurricane Hugo.

\begin{tabular}{|c|c|c|c|c|c|c|c|c|c|c|}
\hline \multirow{2}{*}{$\begin{array}{l}\text { Borrow Area } \\
\text { Scenario }\end{array}$} & \multicolumn{2}{|c|}{ Folly River } & \multicolumn{2}{|c|}{$\begin{array}{l}\text { Stono Inlet Throat } \\
\text { (I) }\end{array}$} & \multicolumn{2}{|c|}{$\begin{array}{l}\text { Stono Ebb Shoal } 1 \\
(J)\end{array}$} & \multicolumn{2}{|c|}{$\begin{array}{l}\text { Stono Ebb Shoal } 2 \\
\text { (K) }\end{array}$} & \multicolumn{2}{|c|}{ Stono Inlet (E) } \\
\hline & Base & Alt 1 & Base & Alt 2 & Base & Alt 3 & Base & Alt 4 & Base & Alt 5 \\
\hline $\begin{array}{l}\text { Current } \\
(\mathrm{m} / \mathrm{s})\end{array}$ & $\begin{array}{l}0.96- \\
1.66\end{array}$ & $\begin{array}{l}0.91- \\
1.33\end{array}$ & $\begin{array}{l}0.85- \\
1.01\end{array}$ & $\begin{array}{l}0.66- \\
0.98\end{array}$ & $\begin{array}{l}0.43- \\
0.69\end{array}$ & $\begin{array}{l}0.4- \\
0.61\end{array}$ & 0.28 & 0.28 & 0.28 & 0.25 \\
\hline
\end{tabular}


The current differences associated with sand removal can be seen in the central and southwest portions of the Folly River borrow area. For the base case, the longshore current turning around the southwest tip of Folly Island entered the borrow area and retained the strength because of shallow water depth. The current continued to flow north across the borrow area. After entering the deeper river channel, a small branch migrated towards the Stono River in the southwest, and the major branch went in the northeast direction towards the upstream of the Folly River. For the alternative, the longshore current lost the strength after entering the dredged borrow area and turned to the upstream of the Folly River inside the borrow area before reaching the river channel (Figure 4-12 and Table 4-4). The maximum changes in current speed due to sand removal occurred when the longshore current flew into the borrow area, which was decreased from $1.66 \mathrm{~m} / \mathrm{s}$ for the base case to $1.08 \mathrm{~m} / \mathrm{s}$ for the alternative.

In the Stono Inlet Throat borrow area (Alternative 2), the main channel area and a large part of the shoaling area were not dredged. The former has an average depth of $8.47 \mathrm{~m}(27.79 \mathrm{ft})$ and the latter $2.46 \mathrm{~m}(8.07 \mathrm{ft})$. While the sand removal from the small off-channel area did not change the current pattern in the entire borrow area, it did reduce current speed by approximately $0.20 \mathrm{~m} / \mathrm{s}(0.66 \mathrm{ft} / \mathrm{s})$ in the actual dredged site (Figure 1-1 and Figure 4-13), which was also related to the decrease of current speed by approximately $0.10 \mathrm{~m} / \mathrm{s}(0.33 \mathrm{ft} / \mathrm{s})$ in the main channel.

The actual area with sand removal in the Stono Ebb Shoal 1 borrow area has an average change in water depth from $6.35 \mathrm{~m}(20.83 \mathrm{ft})$ to $7.55 \mathrm{~m}$ $(24.77 \mathrm{ft})$. As shown in Figure 4-14 and Table 4-4, the change was causing a corresponding decrease in current speed from $0.56 \mathrm{~m} / \mathrm{s}$ to $0.40 \mathrm{~m} / \mathrm{s}$ ( 1.84 to $1.31 \mathrm{ft} / \mathrm{s}$ ) over the sand removal area.

Both the Stono Ebb Shoal 2 and the Stono Inlet borrow areas are located in the offshore area and have a base water depth of more than $10.0 \mathrm{~m}$ $(32.81 \mathrm{ft})$. The large water depths did not change current speeds in those two areas (Figure 4-15 and Figure 4-16). The speed values in Table 4-4 show a maximum change in current speed by approximately $0.03 \mathrm{~m} / \mathrm{s}$ $(0.98 \mathrm{ft} / \mathrm{s})$ before and after sand removal.

\subsubsection{Sediment transport}

Corresponding to wave and current analysis in the previous section, sediment transport rates were calculated. Resulting from sand 
movement, and bed erosion and deposition, morphology (bed volume) changes were examined around each borrow area for the Hurricane Hugo and 2018 periods.

Figure 4-17 shows the spatial distribution of sediment transport rates in the study area on 22 September 1989 at 03:00 (GMT). Comparing with the current distribution in Figure 4-11, it can be seen that the sediment transport pattern is consistent with the current pattern around the Stono Inlet estuarine system. The strongest transport rates occurred in the Stono River channel with a magnitude between 110 and $120 \mathrm{~kg} /(\mathrm{m} \cdot \mathrm{s})$. Nearshore in front of Folly Beach, sediment moved in the longshore direction from northeast to southwest. The longshore transport rate with a value between 10 and $20 \mathrm{~kg} /(\mathrm{m} \cdot \mathrm{s})$ was one order of magnitude smaller than that in the Stono River channel but doubled with a transport rate between 25 and $30 \mathrm{~kg} /(\mathrm{m} \cdot \mathrm{s})$ as turning around the southwest corner of Folly Island. In the offshore area, the sediment transport rate is generally small with a magnitude less than $5 \mathrm{~kg} /(\mathrm{m} \cdot \mathrm{s})$.

Figure 4-17. Calculated sediment transport rates during the Hurricane Hugo Passage on 22 September 1989 at 03:00 (GMT). Polygons indicate the five sand borrow areas.

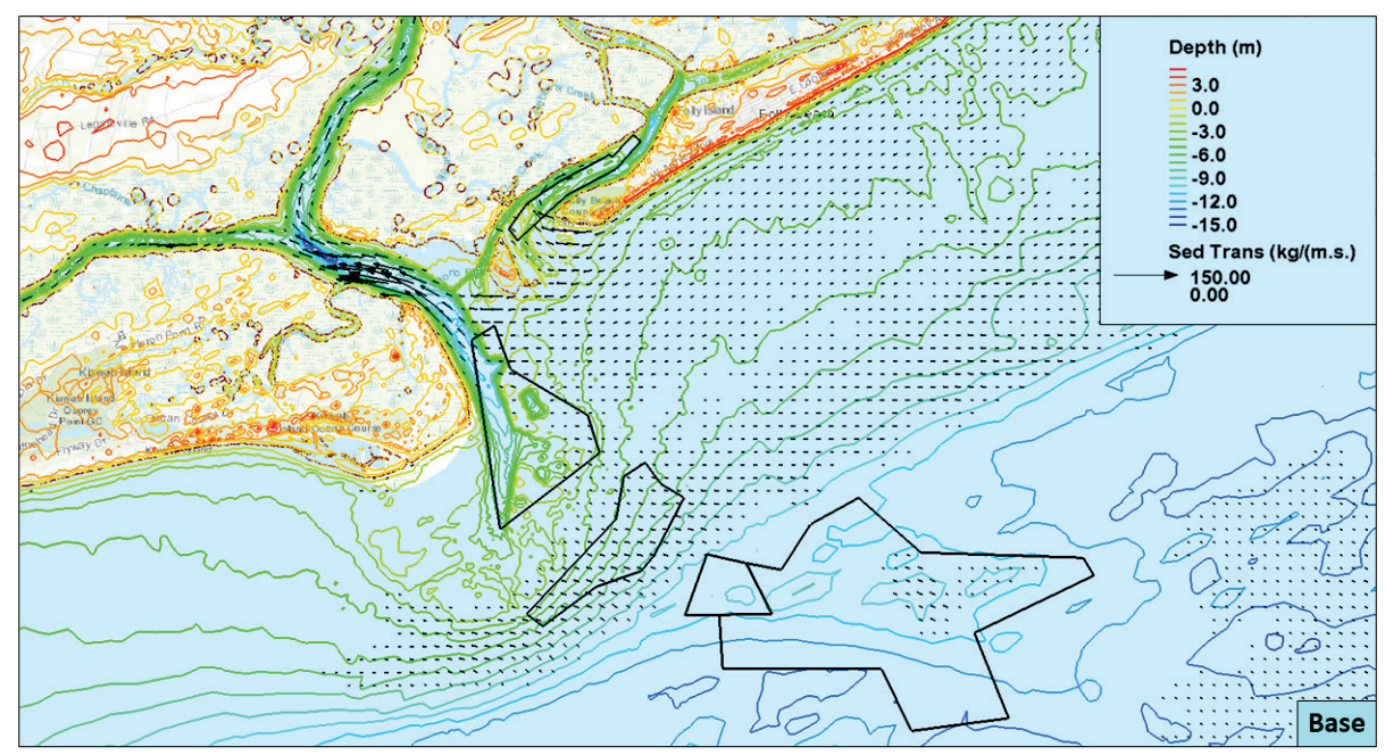

Comparisons of sediment transport rates before (base) and after (alternatives) sand removal from each of the borrow areas are shown in Figure 4-18 to Figure 4-22, respectively. Detailed transport values are listed in Table 4-5. 
Figure 4-18. Comparison of sediment transport rates between (a) base case and (b) Alternative 1 within the Folly River borrow area (the polygon) during the Hurricane Hugo Passage on 22 September 1989 at 03:00 (GMT).

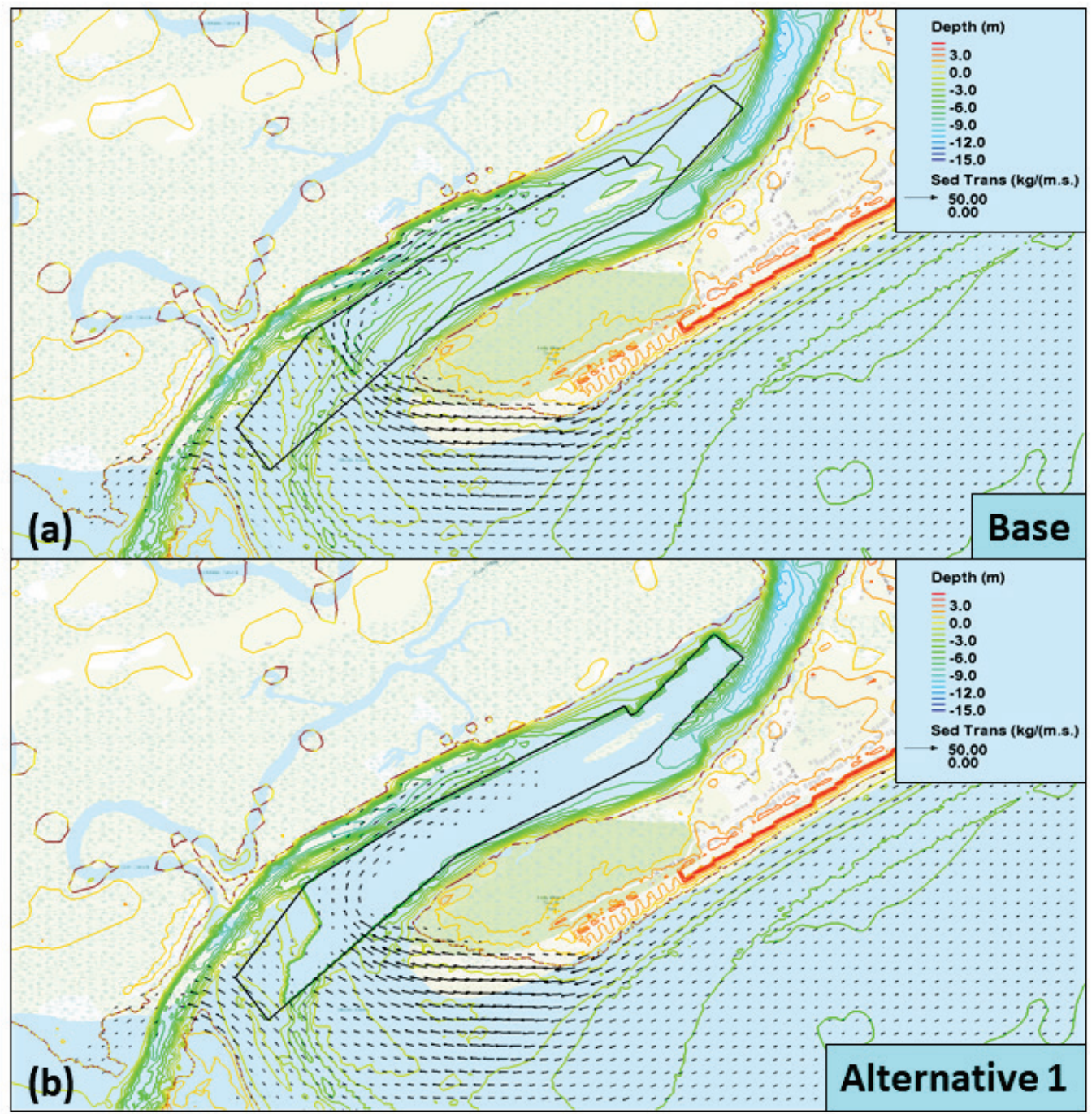


Figure 4-19. Comparison of sediment transport rates between (a) base case and (b) Alternative 2 within the Stono Inlet Throat borrow area (the polygon in the center) during the Hurricane Hugo Passage on 22 September 1989 at 03:00 (GMT).

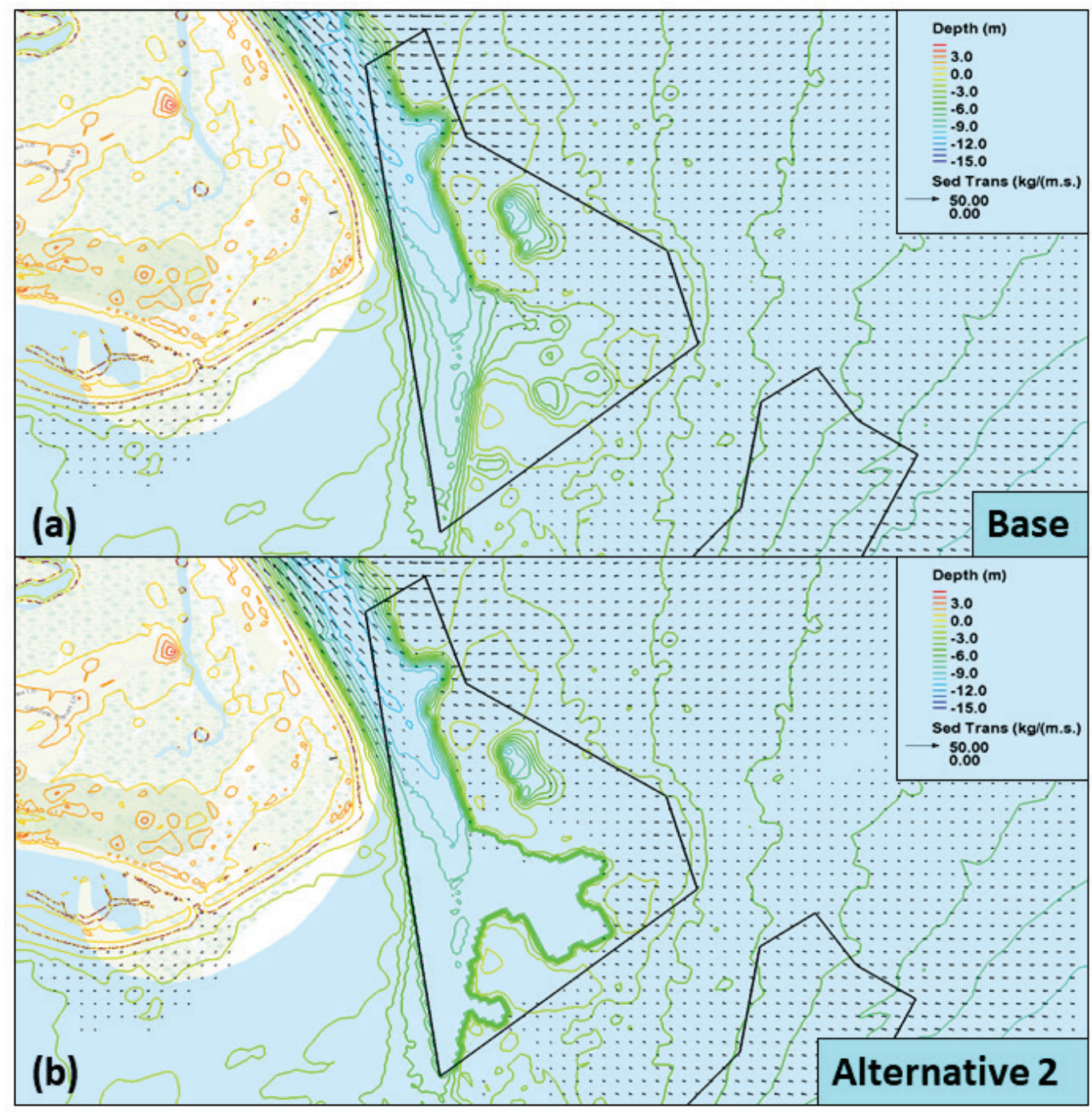


Figure 4-20. Comparison of sediment transport rates between (a) base case and (b) Alternative 3 within the Stono Ebb Shoal 1 borrow area (the polygon in the center) during the Hurricane Hugo Passage on 22 September 1989 at 03:00 (GMT).

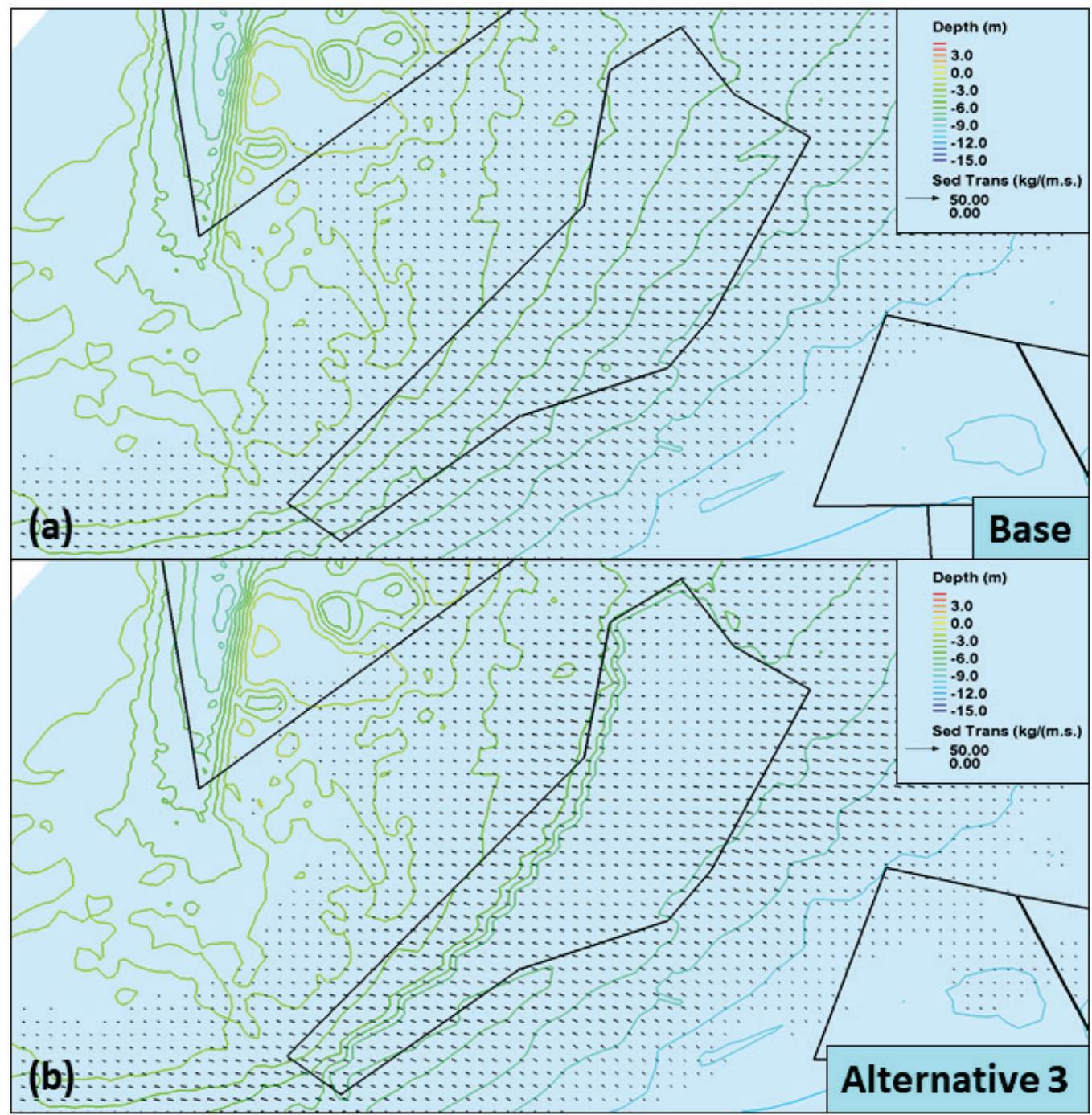


Figure 4-21. Comparison of sediment transport rates between (a) base case and (b) Alternative 4 within the Stono Ebb Shoal 2 borrow area (the polygon in the center) during the Hurricane Hugo Passage on 22 September 1989 at 03:00 (GMT).

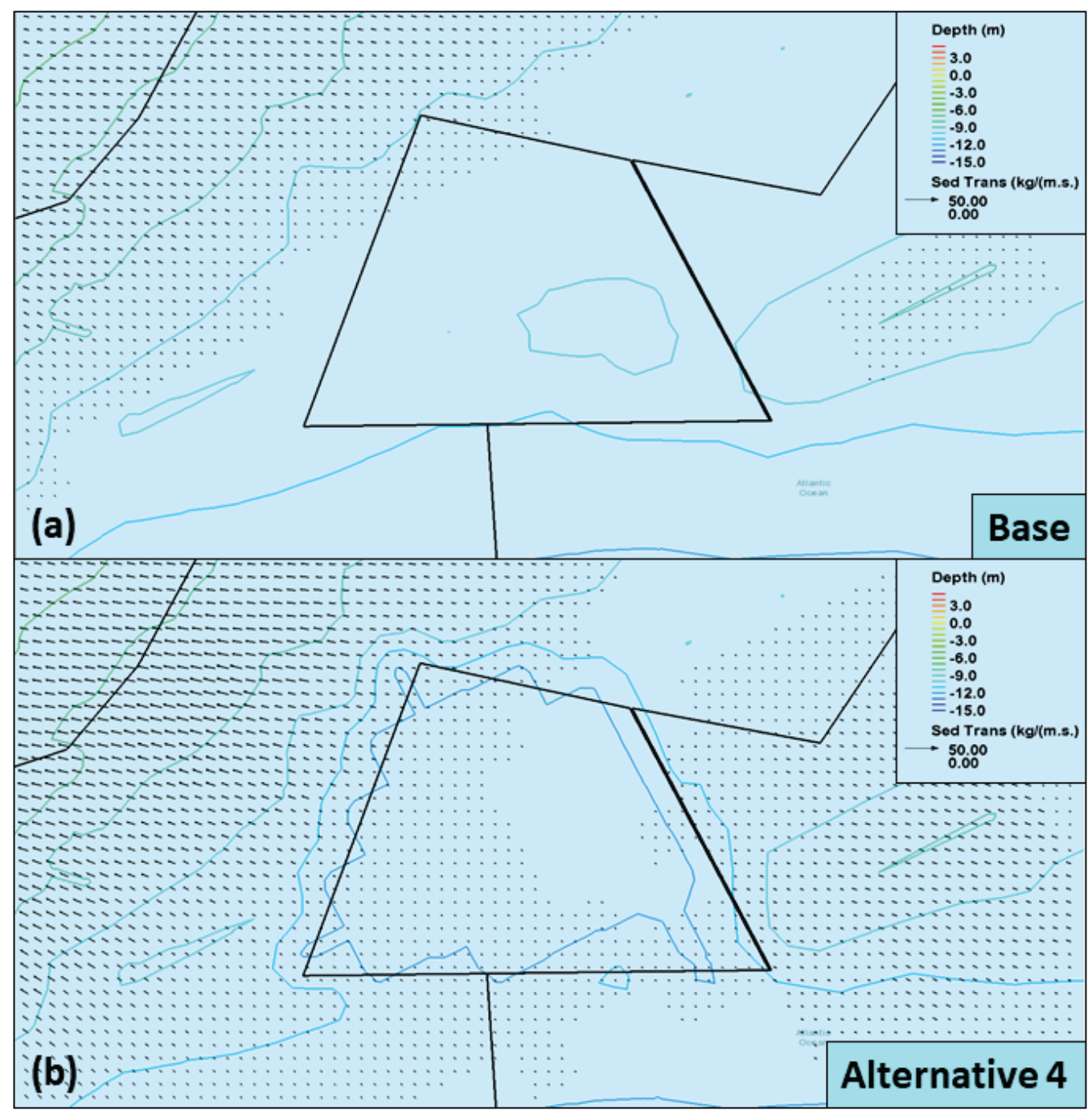


Figure 4-22. Comparison of sediment transport rates between (a) base case and (b) Alternative 5 within the Stono Inlet borrow area (the bigger polygon in the center) during the Hurricane Hugo Passage on 22 September 1989 at 03:00 (GMT).

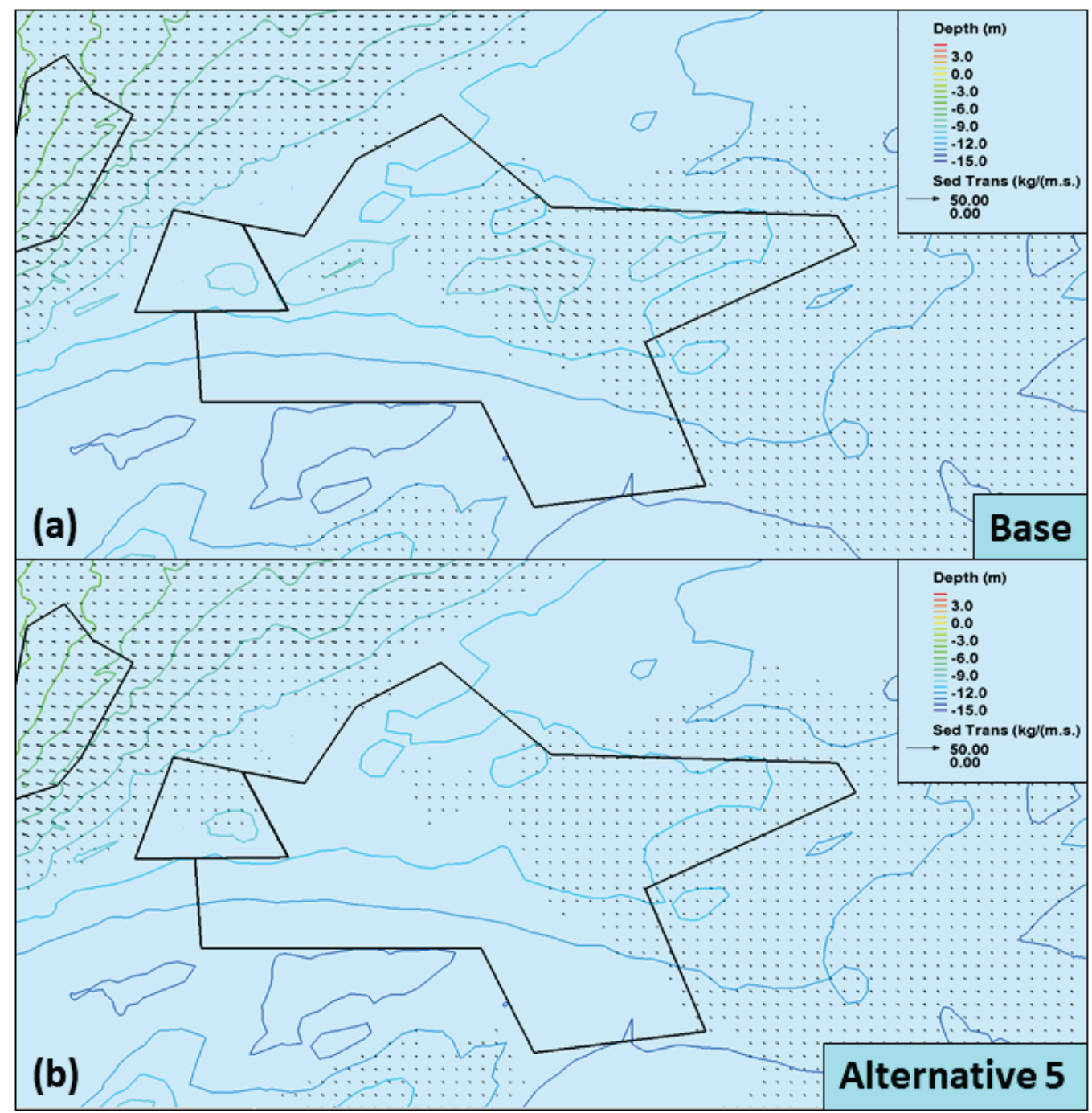

Table 4-5. Comparisons of sediment transport rates between the base case (before sand dredge) and alternatives (after sand dredge) in borrow areas during Hurricane Hugo.

\begin{tabular}{|l|l|l|l|l|l|l|l|l|l|l|}
\hline \multirow{2}{*}{ Borrow Area } & \multicolumn{3}{|l|}{ Folly River } & \multicolumn{2}{l|l}{$\begin{array}{l}\text { Stono Inlet Throat } \\
(\mathrm{I})\end{array}$} & \multicolumn{2}{l|}{$\begin{array}{l}\text { Stono Ebb Shoal 1 } \\
(\mathrm{J})\end{array}$} & \multicolumn{2}{l}{$\begin{array}{l}\text { Stono Ebb Shoal 2 } \\
(\mathrm{K})\end{array}$} & \multicolumn{2}{l|}{ Stono Inlet (E) } \\
\hline Scenario & Base & Alt 1 & Base & Alt 2 & Base & Alt 3 & Base & Alt 4 & Base & Alt 5 \\
\hline $\begin{array}{l}\text { Sediment } \\
\begin{array}{l}\text { Transport Rate } \\
(\mathrm{kg} /(\mathrm{m} . \mathrm{s}))\end{array}\end{array}$ & $\begin{array}{l}19.7- \\
23.3\end{array}$ & $\begin{array}{l}11.0- \\
21.4\end{array}$ & $3.4-7.3$ & $1.6-7.5$ & $\begin{array}{l}7.7- \\
10.3\end{array}$ & $\begin{array}{l}4.6- \\
10.1\end{array}$ & 2.6 & $2.8-3.3$ & $2.7-9.1$ & $2.8-3.4$ \\
\hline
\end{tabular}


For the Folly River borrow area, the vector distribution of sediment transport rates is shown in Figure 4-18. The differences of sediment transport associated with sand removal can be compared with the current field in Figure 4-12. Similarly, the central and southwest portions of the area show major changes in sediment transport rates. For the base case, the sediment transport turning around the southwest tip of Folly Island almost unchanged entering the borrow area (slightly increased from 19.7 to $20.0 \mathrm{~kg} /(\mathrm{m} \cdot \mathrm{s})$ ). For the alternative, the sediment transport rate was reduced significantly (21.4 to $11.0 \mathrm{~kg} /(\mathrm{m} \cdot \mathrm{s})$ ) due to water deepening and relatively large transport occurred in the middle section of the borrow area (Table 4-5).

In the Stono Inlet Throat borrow area, the undredged channel and the east part of the shoaling area show relatively large sediment transport rates approximately 9.0 and $7.5 \mathrm{~kg} /(\mathrm{m} \cdot \mathrm{s})$, respectively, which did not change both for the base and the alternative cases (Figure 4-19). The dredged small off-channel area shows small sediment transport rates, which were reduced from 3.4 to $1.5 \mathrm{~kg} /(\mathrm{m} \cdot \mathrm{s})$ from the base to the alternative cases (Table 4-5). The decrease of transport rates in the dredged area corresponds well to the decrease in currents as shown in Figure 4-13.

Corresponding to decreases in current speed over the sand removal area, sediment transport rates decreased from $7.7-10.3 \mathrm{~kg} /(\mathrm{m} \cdot \mathrm{s})$ to $4.6-10.1$ $\mathrm{kg} /(\mathrm{m} \cdot \mathrm{s})$ for the base and the alternative case in the Stono Ebb Shoal 1, respectively (Table 4-5 and Figure 4-20). Like the Folly River borrow area, sediment transport rates do not change much from the offshore to the dredged area for the base case but decrease for the alternative, which results from depth gradient created by sand removal from the borrow area.

Because of the large water depths in the Stono Ebb Shoal 2 and the Stono Inlet borrow areas, changes in current speeds and sediment transport are insignificant comparing the base case with the alternative case

(Figure 4-21 and Figure 4-22). Sediment transport rates listed in Table 4-5 are generally smaller than $5.0 \mathrm{~kg} /(\mathrm{m} \cdot \mathrm{s})$ in these two areas before and after sand removal.

\subsubsection{Morphology change}

Sediment transport and morphology changes were calculated for the base case during the period when the Hurricane Hugo passed the study area. The calculated morphology changes were obtained by subtracting depth 
values at the end of simulation on 26 September at 00:00 from those at the beginning on 18 September 1989 at oo:oo. The areas with positive values represent sediment accretion and negative values represent sediment erosion in Figure 4-23.

Major morphologic changes presented by the model results in Figure 4-23 occurred in the Stono River channel, nearby the Folly River borrow area between Folly Island and Bird Key, and around the Stono Inlet Throat borrow area off the Stono Inlet navigation channel. The maximum erosion and deposition in the Stono River had a magnitude between 2.0 to $3.0 \mathrm{~m}$ (6.56 to $9.84 \mathrm{ft}$ ) after the hurricane passage. The magnitude of erosion and deposition near Folly Island and at the Stono Inlet Throat area was between 1.0 to $1.5 \mathrm{~m}$ (3.28 to $4.92 \mathrm{ft})$.

Figure 4-23. Morphology changes for the base case in the study area from 18 to 25 September 1989. Warmer colors represent sediment accretion (delineated by red lines) and cooler colors sediment erosion (delineated by blue lines).

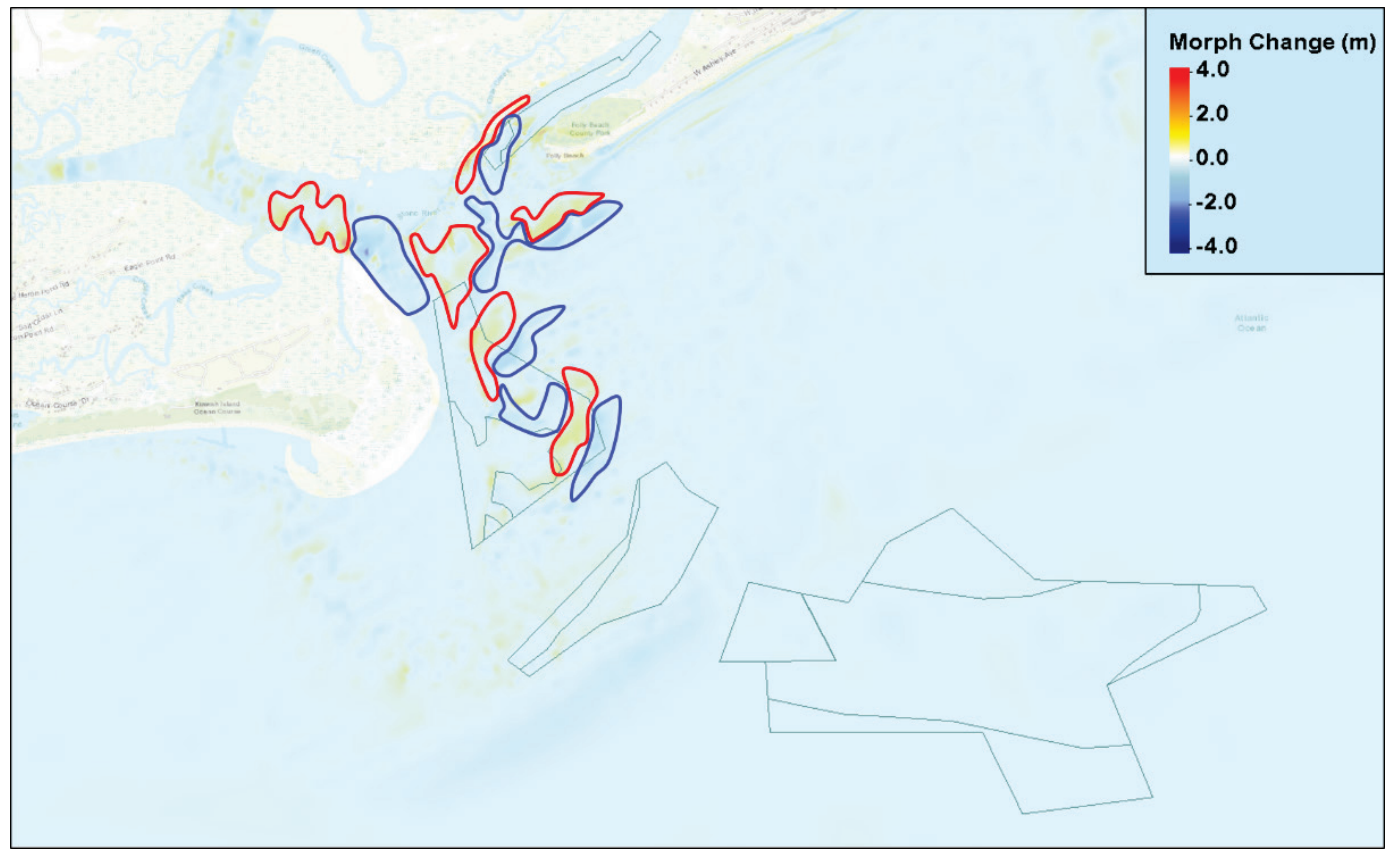

Figure 4-24 shows four longshore erosion and deposition zones along Folly Beach, within which average depths, depth changes, and volume changes due to the hurricane passage are listed in Table 4-6. Erosion Zone 1 extends along the shoreline all the way from the southwest to the northeast and is located in the nearshore area of Folly Island with an average water depth of $0.89 \mathrm{~m}(29.2 \mathrm{ft})$. This erosion zone has an average water depth change of $0.32 \mathrm{~m}(10.5 \mathrm{ft})$ and sand loss of 141,000 cu yd 
$\left(107,634 \mathrm{~m}^{3}\right)$ due to the impact by Hurricane Hugo. Closer to the beach with an average water depth of $0.01 \mathrm{~m}(0.03 \mathrm{ft})$ above MSL is Erosion Zone 2 at the southwest end of Folly Beach, which experiences much less erosion than the deeper erosion zone. Between these two zones is Deposition Zone 2, which shows an average depth change of $0.17 \mathrm{~m} \mathrm{(0.56}$ $\mathrm{ft}$ ), and the total sand accumulation is $17,262 \mathrm{cu}$ yd (13,177 m³). Deposition Zone 1 extends from the north end of Deposition Zone 2 to the northeast of Folly Beach. Because the average depth within this zone is $2.4 \mathrm{~m}(7.87 \mathrm{ft})$ above MSL, the calculated average deposition of $0.02 \mathrm{~m}(0.07 \mathrm{ft})$ indicates that extra sand materials are accumulated on this portion of the beach after the passage of Hurricane Hugo.

Figure 4-24. Morphology changes for the base case nearshore in front of Folly Beach from 18 to 25 September 1989. Warmer colors represent sediment accretion (delineated by red lines), and cooler colors sediment erosion (delineated by blue lines).

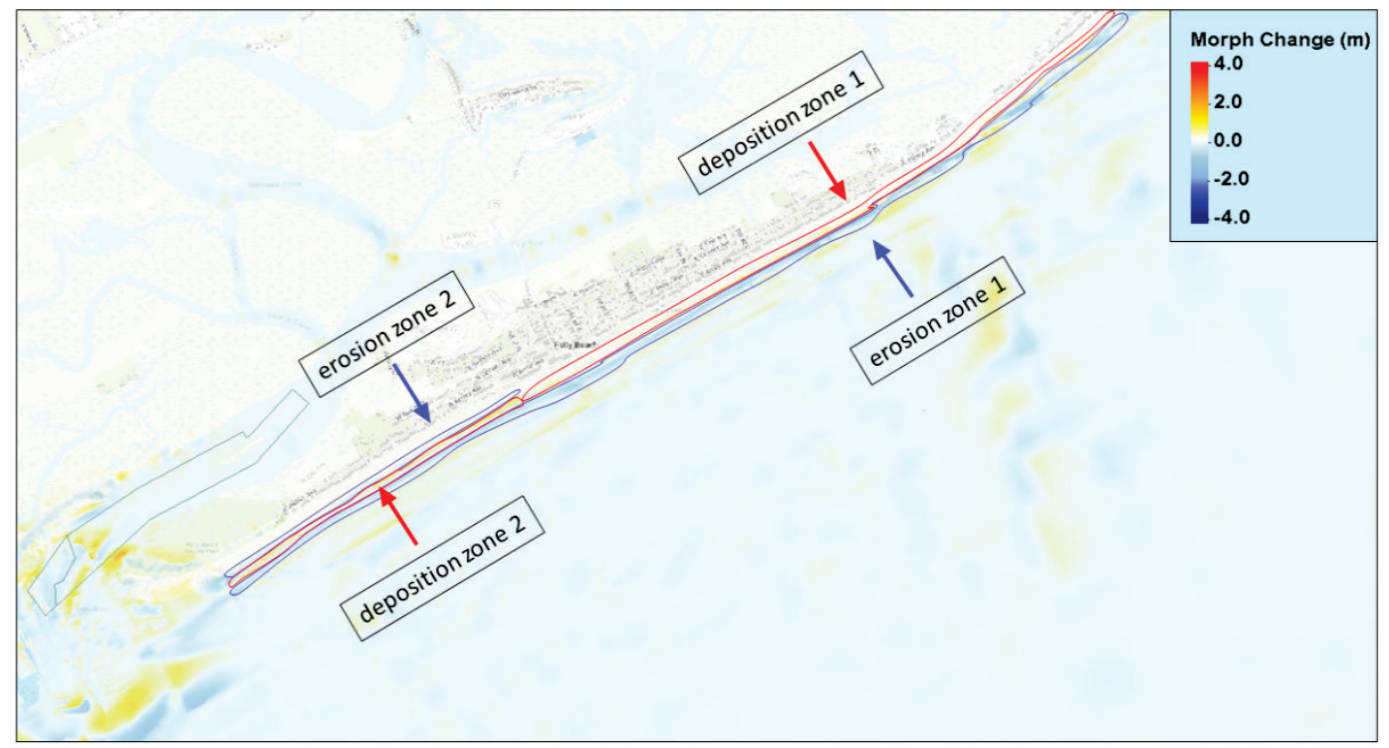

Table 4-6. Longshore erosion and deposition zones in front of Folly Beach during the passage of Hurricane Hugo in September 1989. Positive depths are the land elevation above MSL.

\begin{tabular}{|l|l|l|l|l|}
\hline Variables & $\begin{array}{l}\text { Erosion } \\
\text { Zone 1 }\end{array}$ & $\begin{array}{l}\text { Erosion } \\
\text { Zone 2 }\end{array}$ & $\begin{array}{l}\text { Deposition } \\
\text { Zone 1 }\end{array}$ & $\begin{array}{l}\text { Deposition } \\
\text { Zone 2 }\end{array}$ \\
\hline $\begin{array}{l}\text { Average Depth } \\
\text { Change }(\mathrm{m})\end{array}$ & 0.32 & 0.07 & 0.02 & 0.17 \\
\hline Average Depth $(\mathrm{m})$ & -0.89 & 0.01 & 2.4 & -1.43 \\
\hline $\begin{array}{l}\text { Volume Change } \\
\text { (cu yd) }\end{array}$ & 141000 & 6836 & 4536 & 17262 \\
\hline
\end{tabular}


Comparisons of morphology changes before (base) and after (alternatives) sand removal from each of the borrow areas are shown in Figure 4-25 to Figure 4-29, respectively. The maximum erosion and deposition values are listed in Table 4-7.

Figure 4-25. Comparison of morphology changes between (a) base case and (b) Alternative 1 within the Folly River borrow area during the Hurricane Hugo passage from 18 to 25 September 1989. Warmer colors represent sediment accretion and cooler colors sediment erosion.

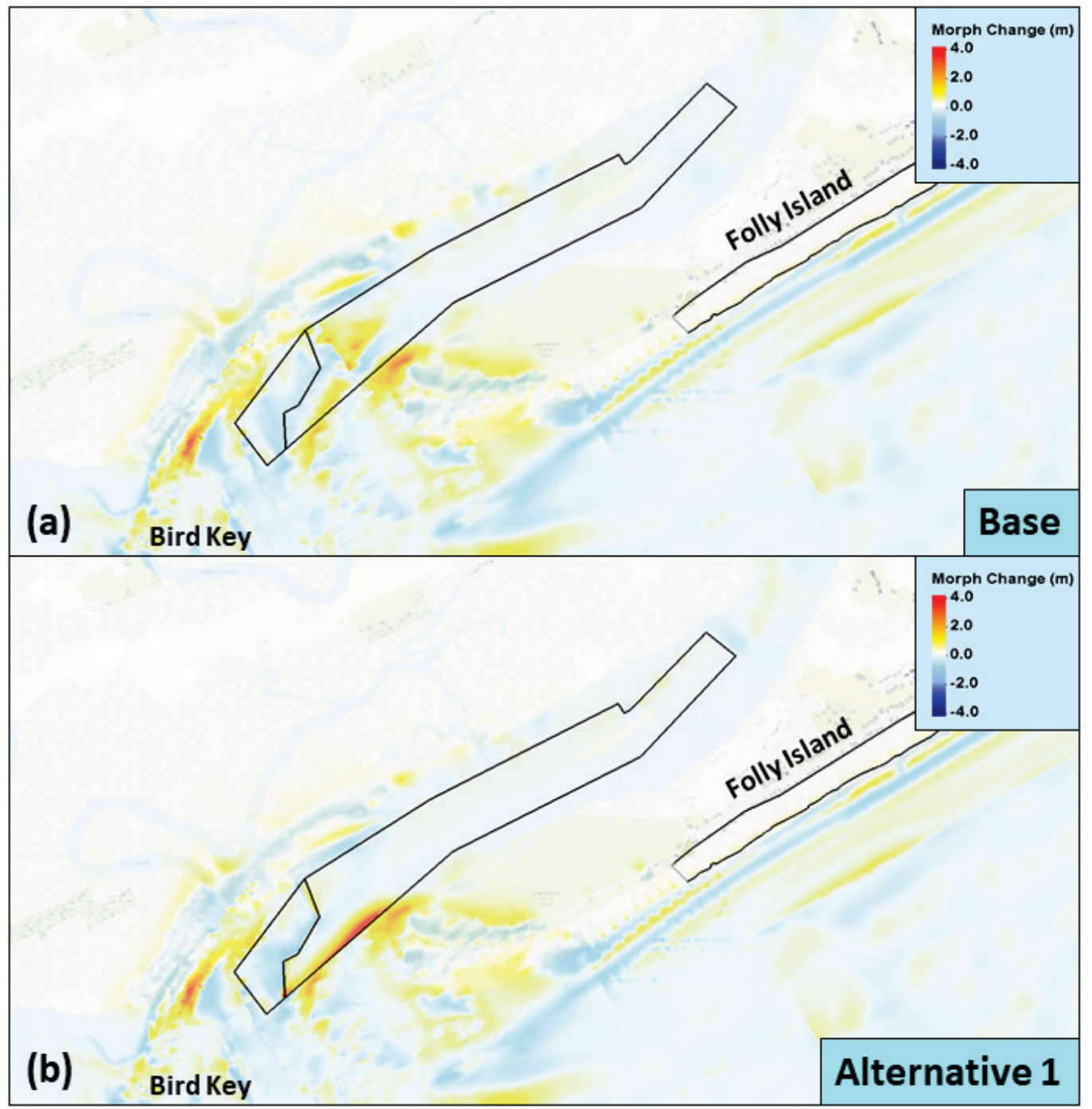


Figure 4-26. Comparison of morphology changes between (a) base case and (b) Alternative 2 within the Stono Inlet Throat borrow area during the Hurricane Hugo passage from 18 to 25 September 1989. Warmer colors represent sediment accretion and cooler colors sediment erosion.

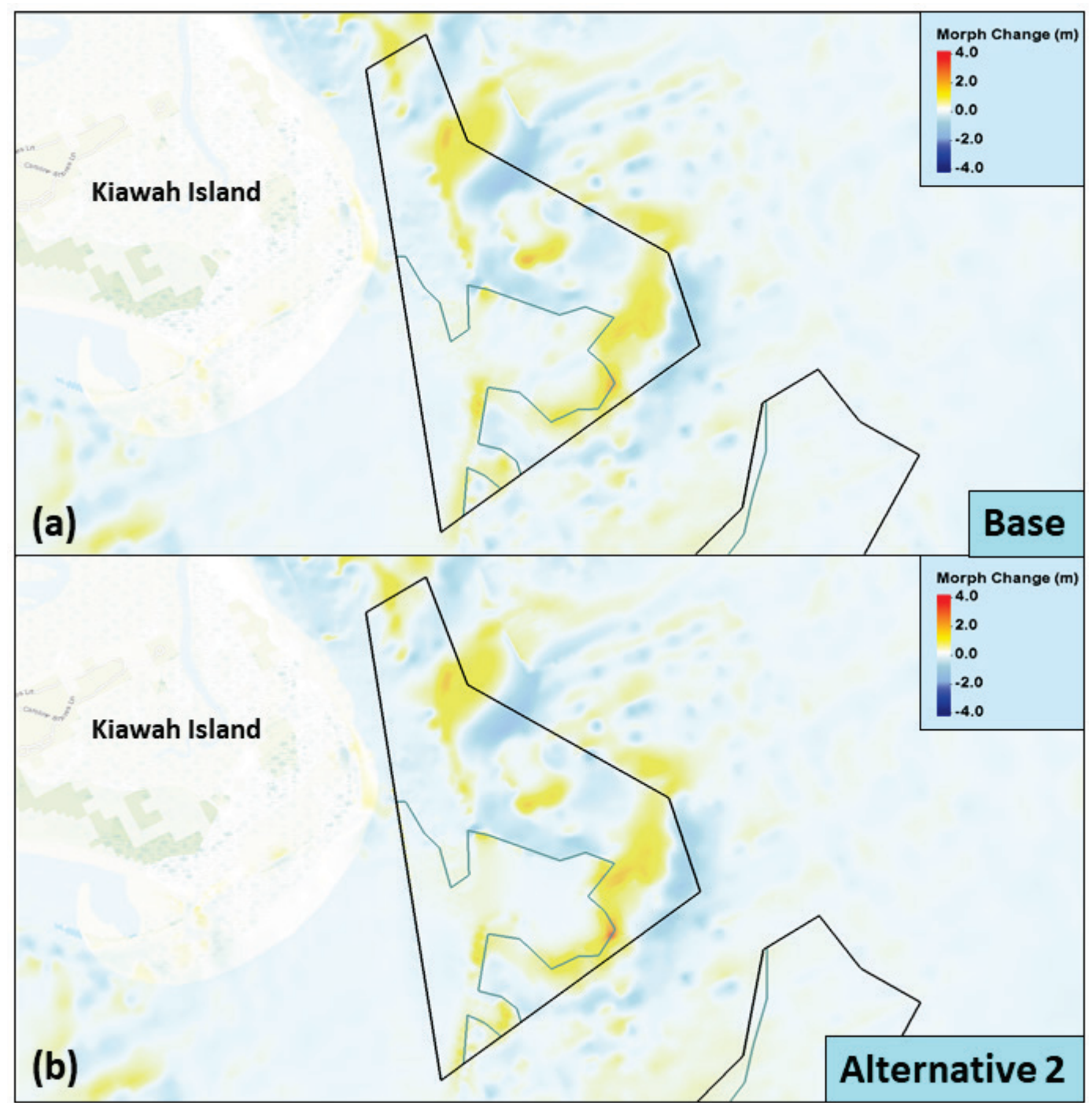


Figure 4-27. Comparison of morphology changes between (a) base case and (b) Alternative 3 within the Stono Ebb Shoal 1 borrow area during the Hurricane Hugo passage from 18 to 25 September 1989. Warmer colors represent sediment accretion and cooler colors sediment erosion.

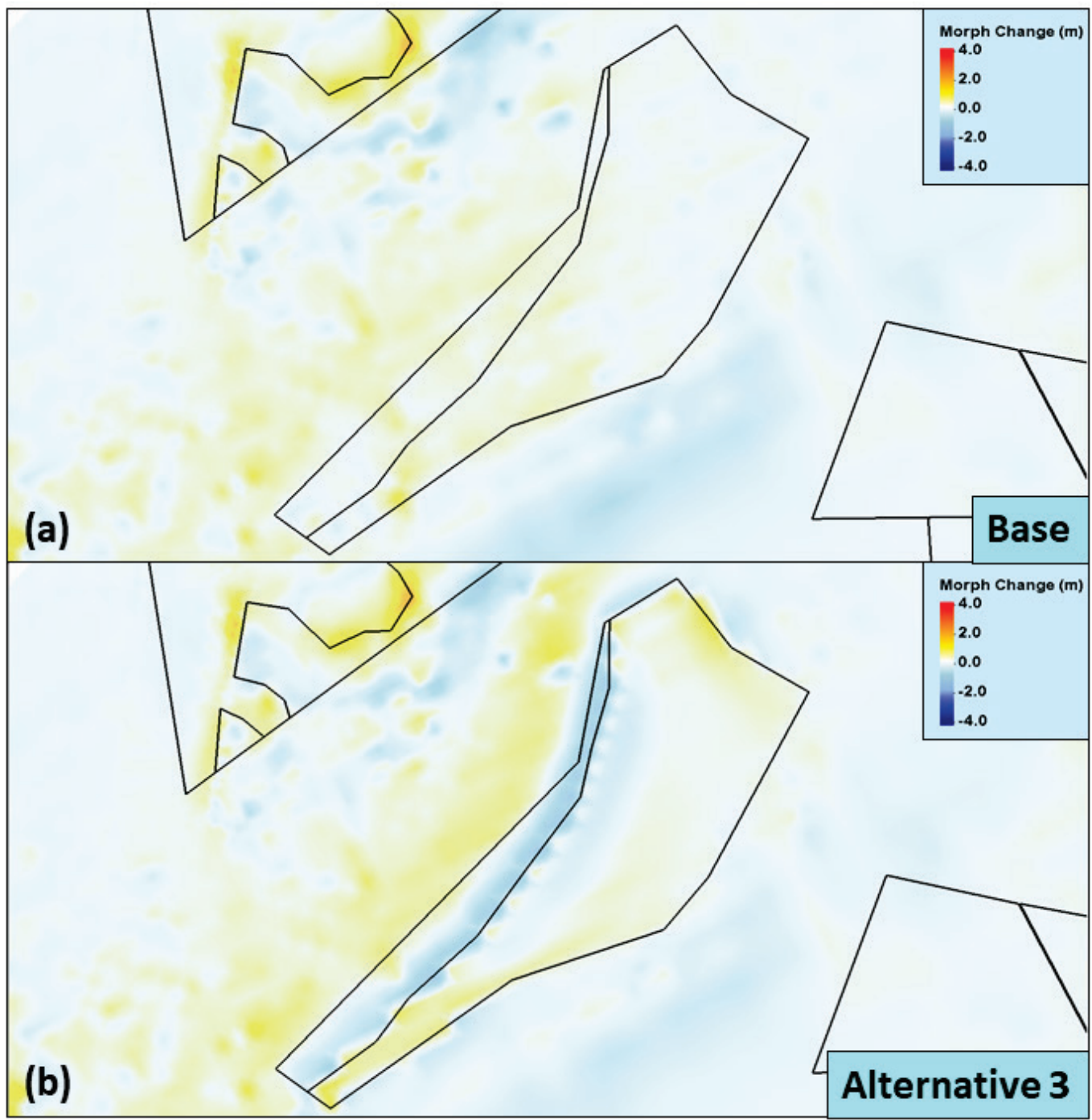


Figure 4-28. Comparison of morphology changes between (a) base case and (b) Alternative 4 within the Stono Ebb Shoal 2 borrow area during the Hurricane Hugo passage from 18 to 25 September 1989. Warmer colors represent sediment accretion and cooler colors sediment erosion..

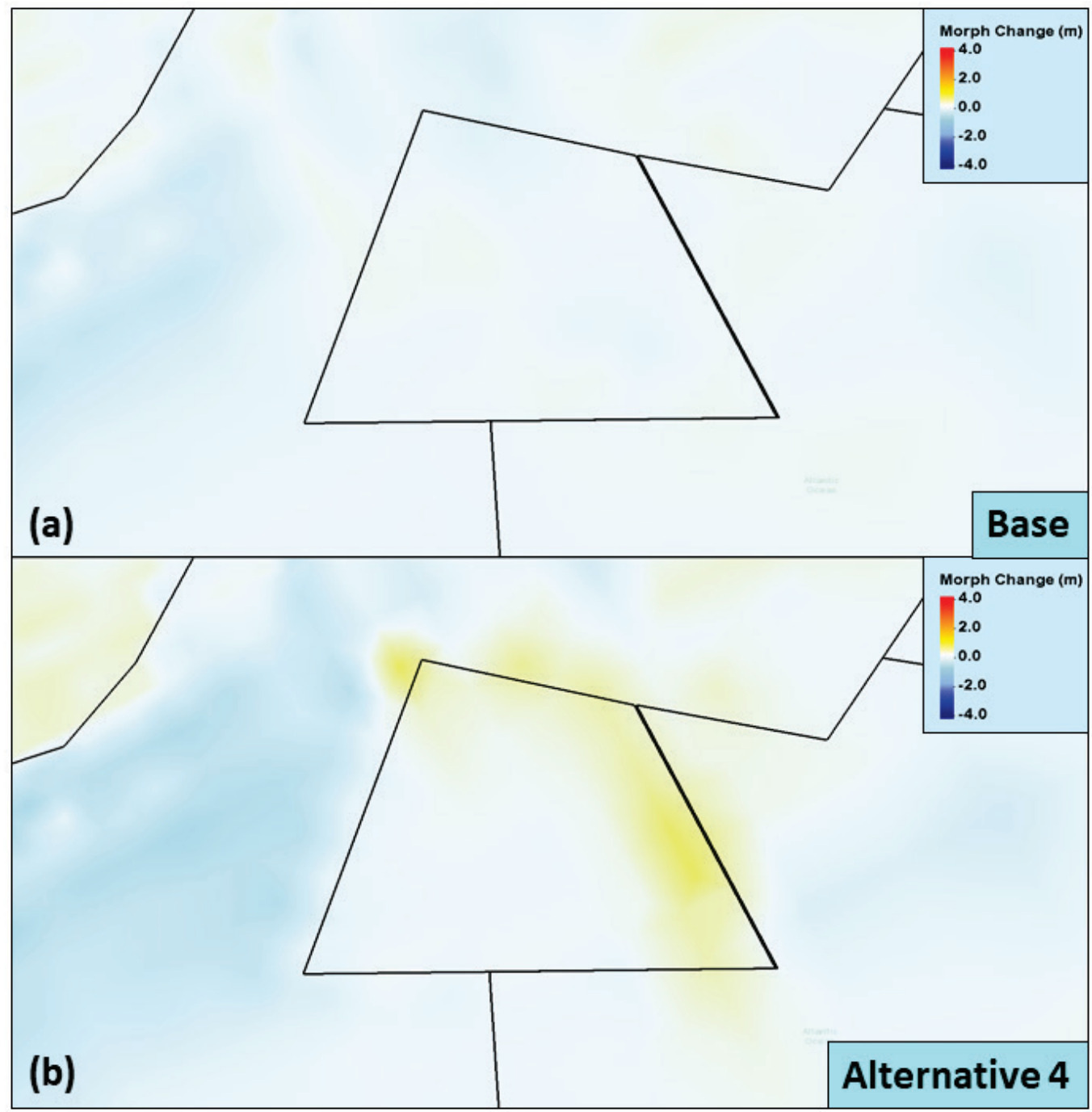


Figure 4-29. Comparison of morphology changes between (a) base case and (b) Alternative 5 within the Stono Inlet borrow area during the Hurricane Hugo passage from 18 to 25 September 1989. Warmer colors represent sediment accretion and cooler colors sediment erosion.

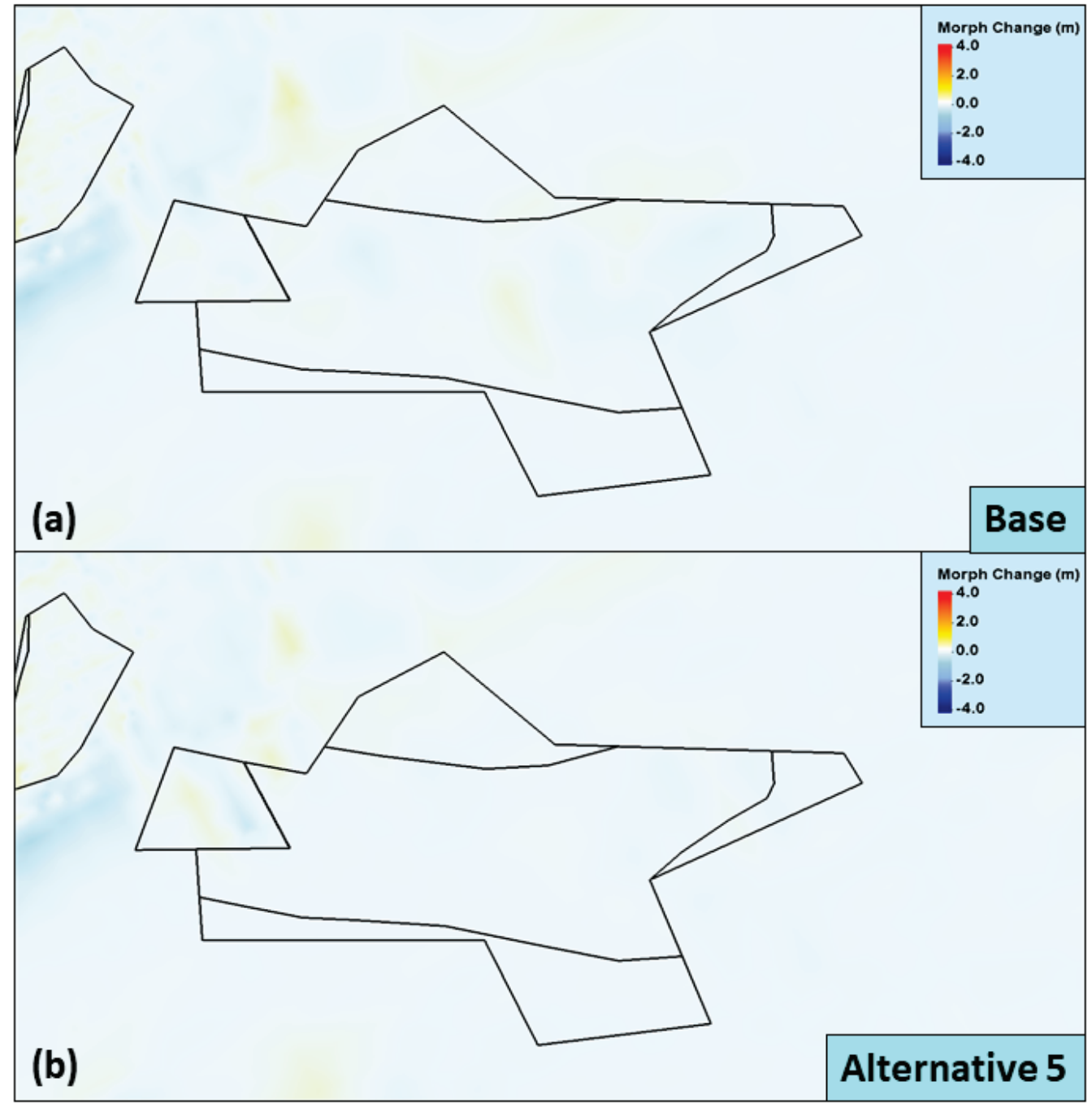

Table 4-7. Comparisons of depth changes between the base case (before sand dredge) and alternatives (after sand dredge) in borrow areas during Hurricane Hugo.

\begin{tabular}{|c|c|c|c|c|c|c|c|c|c|c|}
\hline \multirow{2}{*}{$\begin{array}{l}\text { Borrow Area } \\
\text { Scenario }\end{array}$} & \multicolumn{2}{|c|}{ Folly River } & \multicolumn{2}{|c|}{$\begin{array}{l}\text { Stono Inlet } \\
\text { Throat (I) }\end{array}$} & \multicolumn{2}{|c|}{$\begin{array}{l}\text { Stono Ebb } \\
\text { Shoal } 1(J)\end{array}$} & \multicolumn{2}{|c|}{$\begin{array}{l}\text { Stono Ebb } \\
\text { Shoal } 2(\mathrm{~K})\end{array}$} & \multicolumn{2}{|c|}{ Stono Inlet (E) } \\
\hline & Base & Alt 1 & Base & Alt 2 & Base & Alt 3 & Base & Alt 4 & Base & Alt 5 \\
\hline Erosion (m) & -0.7 & -1.2 & -1.3 & -1.4 & -0.2 & -1.2 & -0.05 & -0.05 & -0.05 & -0.04 \\
\hline Deposition (m) & 1.5 & 3.5 & 1.4 & 2.5 & 0.7 & 0.7 & 0.06 & 0.6 & 0.12 & 0.14 \\
\hline
\end{tabular}


The base case in the Folly River borrow area shows that large depth changes primarily occurred in the area impacted by flows turning around Folly Island. The alternative case in the actual dredged area shows only large deposition at the edge of the borrow area and no significant erosion inside the borrow area because of the decrease of currents due to sand removal (Figure 4-25). For the base case, the maximum erosion and deposition are 0.7 and $1.5 \mathrm{~m}$ (2.3 and $4.92 \mathrm{ft}$ ), and for the alternative case, 1.2 and $3.5 \mathrm{~m}$ (3.94 and $11.48 \mathrm{ft}$ ), respectively (Table 4-7). In the central and northern portion of the borrow area, sand movement is insignificant and depth changes for both cases are between 0.02 to $0.1 \mathrm{~m}$ (0.07 to $0.33 \mathrm{ft}$ ).

In the Stono Inlet Throat borrow area, the large erosion and deposition in the range of 1.0 to $1.5 \mathrm{~m}$ (3.28 to $4.92 \mathrm{ft}$ ) occurred in the undredged shoaling and the east part of the borrow area. Sediment deposition can be seen but not much erosion occurred in the actual dredged area (Figure 4-26 and Table 4-7), where the maximum deposition is larger than $1.0 \mathrm{~m}$ $(3.28 \mathrm{ft})$ and the maximum erosion is approximately $0.1 \mathrm{~m}(0.33 \mathrm{ft})$ both for the base and the alternative cases.

Figure 4-27 shows noticeable differences in erosion and deposition patterns between the base and the alternative cases in the Stono Ebb Shoal 1 borrow area. For the base case sediment deposition occurred in the area and erosion happened outside the borrow area. For the alternative case, sediment materials were eroded between the actual dredged and undredged portions of the borrow area and relatively larger amount of sand was deposited in the dredged portion. Table 4-7 lists that the maximum erosion in the borrow area is only $0.19 \mathrm{~m}$ for the base case but has a much larger value of $1.2 \mathrm{~m}(3.94 \mathrm{ft})$ for the alternative case. The deposition values for both cases are similar, but the deposition area for the alternative case is much larger, implying more materials were moving into the dredged portion of the borrow area.

When examining the Stono Ebb Shoal 2 borrow area, it can be seen that depth changes are minimal for the base case (Figure 4-28). The erosion and deposition values shown in Table 4-7 are approximately $0.05 \mathrm{~m}$ ( $0.16 \mathrm{ft})$. However, the deposition is larger by an order of magnitude for the alternative case comparing to the base case. The spatial contours of the morphology change indicate that sand materials were eroded from the outside of the borrow area. 
Located in deep offshore area, the currents in the Stono Inlet borrow area are weak, and slight morphology changes are observed in Figure 4-29. As shown in Table 4-7, the maximum erosion in the area is approximately $0.05 \mathrm{~m}(0.16 \mathrm{ft})$, and the maximum deposition is a little above $0.1 \mathrm{~m}$ $(0.33 \mathrm{ft}$ ). The erosion and deposition pattern does not change much before and after sand removal.

Associated with sediment transport and morphology change, volume changes and sediment budget are analyzed to further assess the storm impact on the borrow areas and nearshore Folly Beach area. Comparisons of bed volume changes between the base and alternative cases in the designated and actual borrow areas during the passage of Hurricane Hugo are listed in Table 4-8.

Table 4-8. Comparisons of bed volume changes (cubic yard) between the base case (before sand dredge) and alternatives (after sand dredge) in designated and actual borrow areas during Hurricane Hugo. The negative sign indicates the volume loss and the positive the volume gain.

\begin{tabular}{|c|c|c|c|c|c|c|c|c|c|c|}
\hline \multirow{2}{*}{$\begin{array}{l}\text { Borrow Area } \\
\text { Scenario }\end{array}$} & \multicolumn{2}{|c|}{ Folly River } & \multicolumn{2}{|c|}{$\begin{array}{l}\text { Stono Inlet Throat } \\
\text { (I) }\end{array}$} & \multicolumn{2}{|c|}{$\begin{array}{l}\text { Stono Ebb Shoal } \\
1(J)\end{array}$} & \multicolumn{2}{|c|}{$\begin{array}{l}\text { Stono Ebb Shoal } \\
2(\mathrm{~K})\end{array}$} & \multicolumn{2}{|c|}{$\begin{array}{l}\text { Stono Inlet } \\
\text { (E) }\end{array}$} \\
\hline & Base & Alt 1 & Base & Alt 2 & Base & Alt 3 & Base & Alt 4 & Base & Alt 5 \\
\hline $\begin{array}{l}\text { Designated } \\
\text { Area }\end{array}$ & 32780 & 62413 & 190362 & 218344 & 144840 & -73061 & 2672 & 123504 & -3755 & 24484 \\
\hline Actual Area & 47338 & 78545 & 111602 & 135880 & 101683 & 132058 & 2672 & 123504 & 32399 & -2378 \\
\hline
\end{tabular}

The calculations show that Hurricane Hugo caused net sediment accretion both for the base and the alternative cases in the Folly River borrow area. Comparing with the base case, the amount of accretion for the alternative case increases by $90 \%$ and $66 \%$ in the designated and the actual dredged areas, respectively. Comparing with the designated area, the amount of accretion in the actual dredged area increases by $44 \%$ and $26 \%$ for the base and the alternative cases, respectively (Table 4-8). The general trend of sediment accretion for different scenarios in different dredge areas indicates that (1) the Folly River borrow area is a sand trap zone, (2) sand removal in the borrow area results in more sediment infilling, and (3) more erosion occurs in the undredged portion of the borrow area. 
The erosion and deposition values in Table 4-8 indicate that the Stono Inlet Throat borrow area is also located in a sand trap zone and has the largest sand accumulation among the other areas. Comparing with the base case, the accretion for the alternative case increases by $15 \%$ and $22 \%$ in the designated and the actual dredged areas, respectively. Comparing with the designated area, the amount of accretion in the actual dredged area is smaller for the base and the alternative cases. Considering much smaller actual dredged area within the designated area, the sediment accretion in this area is quite significant.

The Stono Ebb Shoal 1 borrow area is also partially dredged. Table 4-8 shows that net accretion occurs in the actual dredged area but net erosion occurs for the alternative case in the designated area. Also, comparing with the base case, the accretion for the alternative case increases by $30 \%$ in the actual dredged areas. Those values indicate that, associated with sand removal, large erosion occurred in the undredged portion of the borrow area and large amounts of eroded materials moved into the actual dredged area. The trend of volume changes in this area is consistent with morphology change as shown in Figure 4-28.

The Stono Ebb Shoal 2 borrow area has the same designated and actual dredged area. Because sand removal creates void space, materials deposited in the area increase by two orders of magnitude from the value in the base case $\left(2,700 \mathrm{cu}\right.$ yd $\left.\left[2,000 \mathrm{~m}^{3}\right]\right)$ to the alternative case $(123,500$ cu yd [94,300 m3]) (Table 4-8).

In the designated Stono Inlet borrow area, Table 4-8 shows net erosion for the base case but net accretion for the alternative case. Although both the base and alternative cases show net erosion in the actual dredged area, the amount of erosion for the alternative case is much smaller than that for the base case, meaning that sand removal still causes new deposition in this borrow area. It is also learned from the volume changes in Table 4-8 that net deposition occurs in the undredged portion of the borrow area.

To examine sediment transport and volume changes nearshore Folly Beach, eight polygons are drawn to embrace the 18 transects in the nearshore zone (Figure 4-30). Along the shoreline from the southwest to northeast of Folly Island, the polygons are named from P1 through P8, and each polygon has an approximate longshore length of 1,000 $\mathrm{m}(3,281 \mathrm{ft})$. Polygons P1 to P6 coincide with Reaches 1 to 21, and polygons P6 to P8 
coincide with Reaches 22-26, which correspond to two different berm designs. Nearshore sediment budget and bed volume changes are analyzed around those polygons.

Figure 4-30. Eight polygons in the nearshore Folly Beach.

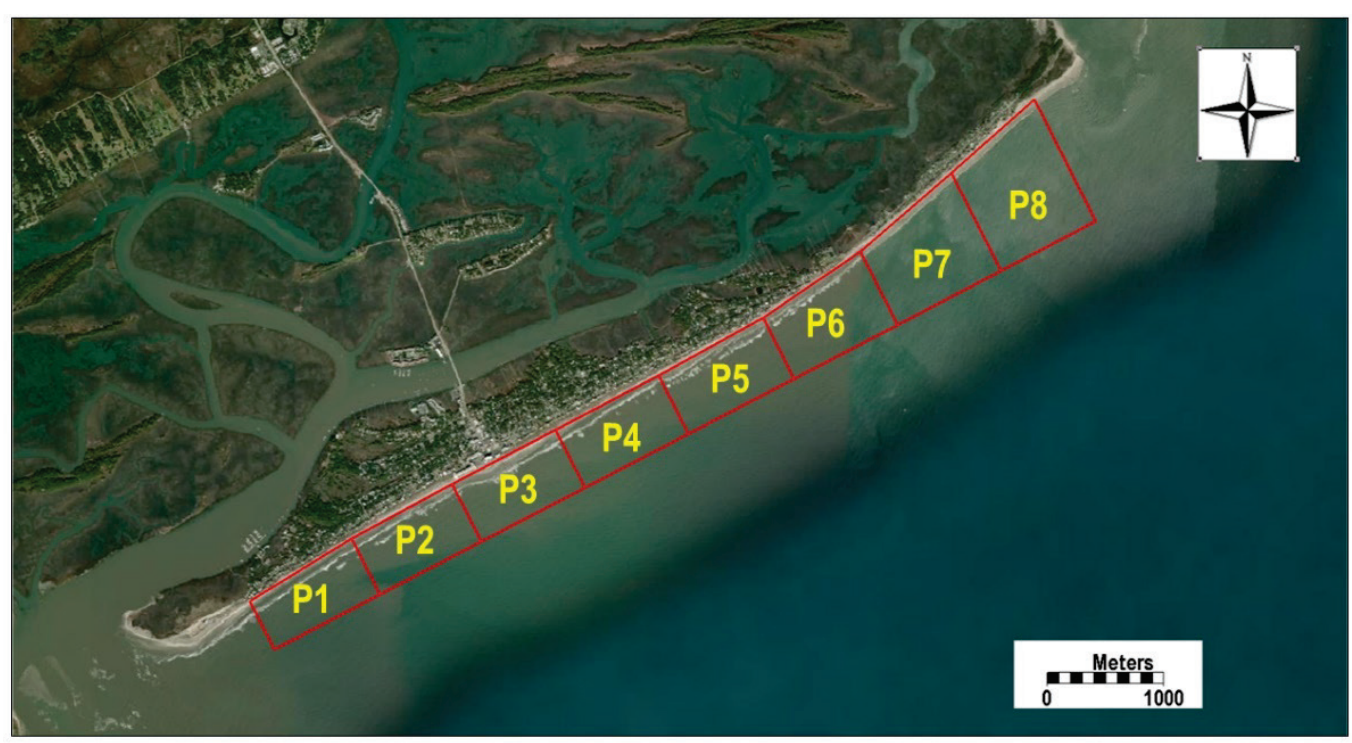

Total sediment transport across each polygon line is calculated, the transport directions are drawn, and sediment balance for each polygon is indicated by a positive (volume gain) or negative (volume loss) sign in Figure 4-31. Overall, in the polygon areas, the persistent longshore transport direction is towards southwest and the cross-shore transport direction is varying. Close to the southwest end of Folly Beach, polygon areas $\mathrm{P} 1$ and $\mathrm{P} 2$ have net sand gain, and in the middle portion of the beach, polygon areas $\mathrm{P}_{3}, \mathrm{P}_{4}$, and $\mathrm{P}_{5}$ show net sand loss. Polygon areas $\mathrm{P} 6$ and P8 in the northeast part of the beach also show net sand gain. 
Figure 4-31. The calculated total sediment transport directions across polygon lines. The positive sign indicates bed volume gain, and the negative sign indicates volume loss within the corresponding polygon area.

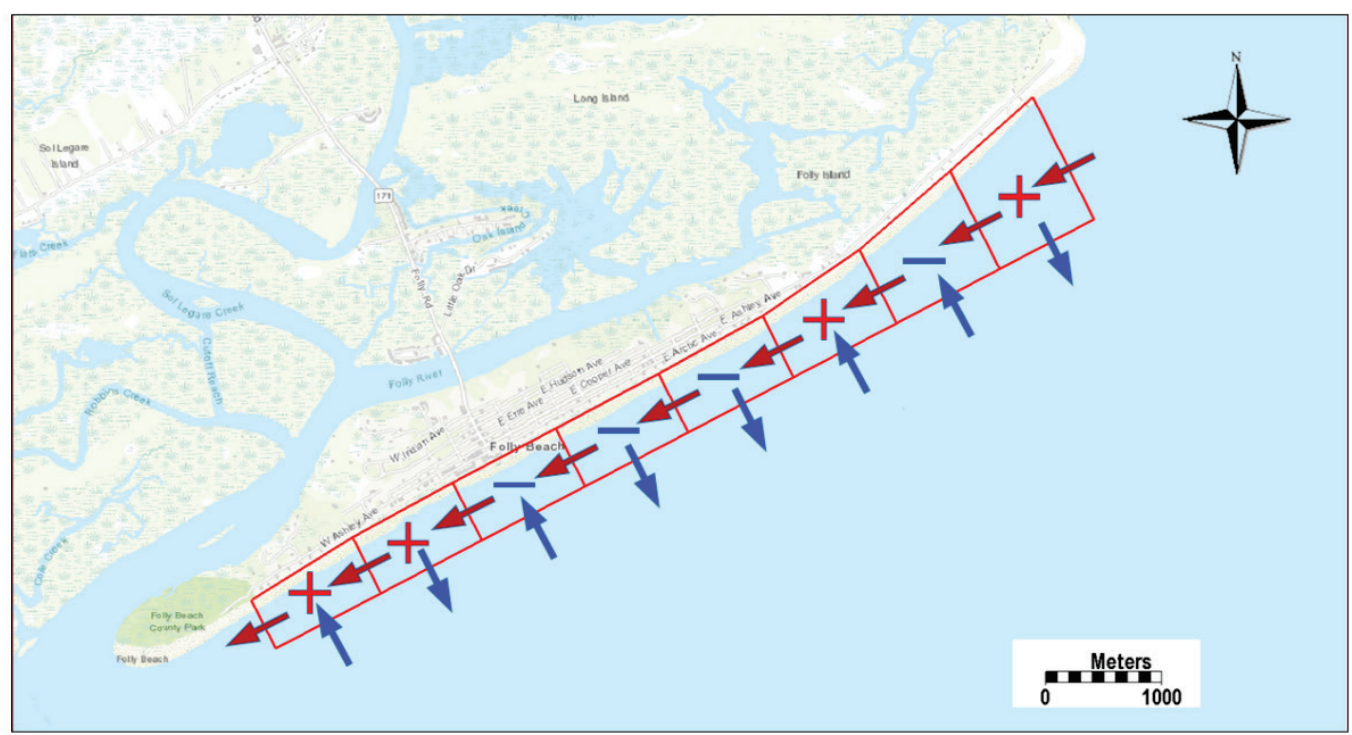

Based on the morphology changes, volume changes within each polygon are estimated, and values are listed in Table 4-9.

Table 4-9. Bed volume changes (cubic yard) for the base case (before sand dredge) and alternatives (after sand dredge) in polygon areas as shown in Figure 4-30 during Hurricane Hugo. The negative sign indicates the volume loss, and the positive sign indicates the volume gain.

\begin{tabular}{|l|l|l|l|l|l|l|}
\hline \multirow{2}{*}{ Area } & \multicolumn{6}{|c|}{ Alternative } \\
\cline { 2 - 7 } & Base & 1 & 2 & 3 & 4 & 5 \\
\hline P1 & 7617 & 7655 & 7781 & 7942 & 11923 & 7690 \\
\hline P2 & 6119 & 6205 & 5894 & 6054 & 8412 & 6194 \\
\hline P3 & -9181 & -9082 & -9094 & -8952 & -12638 & -8969 \\
\hline P4 & -2720 & -2868 & -3227 & -2730 & -10419 & -2916 \\
\hline P5 & -18741 & -19100 & -19058 & -18795 & -27630 & -18938 \\
\hline P6 & 13575 & 13681 & 13763 & 13564 & 16066 & 13968 \\
\hline P7 & -2745 & -2617 & -2443 & -2472 & -5428 & -2514 \\
\hline P8 & 1002 & 852 & 725 & 928 & 56 & 540 \\
\hline
\end{tabular}


For the base case, net sediment accumulation in the southwest and the northeast sections of Folly Beach (P1 and $\left.\mathrm{P}_{2}\right)$ is approximately 13,700 and 11,800 cu yd (10,458 and 9,008 $\left.\mathrm{m}^{3}\right)$, respectively, after the hurricane passage. The middle section of the beach ( $\mathrm{P}_{3}$ to $\mathrm{P}_{5}$ ) shows net sand loss of $30,600 \mathrm{cu} y d\left(23,359 \mathrm{~m}^{3}\right)$. For the alternatives, the volume gain or loss within each polygon area is not off much from the base case because of the flow pattern in the study area and the distance between those sand borrow areas and the Folly Beach area.

Volume changes around Bird Key Island and Kiawah Island are examined within polygon areas shown in Figure 4-32. For Bird Key Island, the polygon area is surrounding the island. Three polygons are specified in the nearshore area of Kiawah Island, which are on the east, southeast, and south sides of the island. Comparisons among the base and alternative cases are made and results shown in Table 4-10.

Figure 4-32. One polygon area surrounding Bird Key Island and three polygons on the east, southeast (SE), and south sides of Kiawah Island.

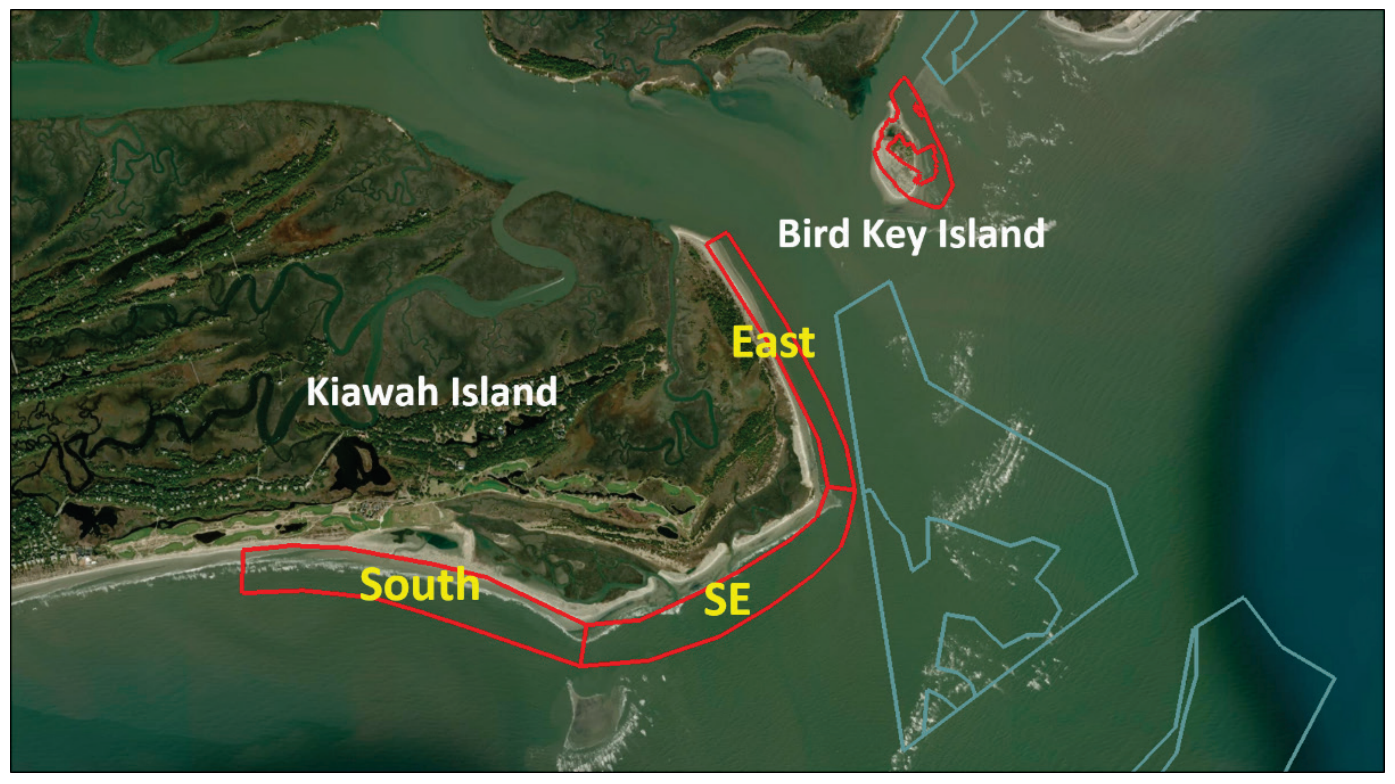


Table 4-10. Bed volume changes (cubic yard) for the base case (before sand dredge) and alternatives 1, 2, and 3 (after sand dredge) in polygon areas around Bird Key Island and Kiawah Island during the passage of Hurricane Hugo in September 1989. The negative sign indicates the volume loss and the positive sign indicates the volume gain.

\begin{tabular}{|c|c|c|c|c|c|}
\hline \multirow{2}{*}{\multicolumn{2}{|c|}{ Area }} & \multicolumn{4}{|c|}{ Alternative } \\
\hline & & Base & 1 & 2 & 3 \\
\hline \multicolumn{2}{|c|}{ Bird Key Island } & -8516 & -7609 & -8424 & -8537 \\
\hline \multirow{3}{*}{$\begin{array}{l}\text { Kiawah } \\
\text { Island }\end{array}$} & East & -20846 & -20662 & -21362 & -20961 \\
\hline & SE & -24738 & -25779 & -26119 & -24683 \\
\hline & South & -6850 & -7088 & -6919 & -6985 \\
\hline
\end{tabular}

Around Bird Key Island, all the cases show material loss after the passage of Hurricane Hugo. Comparing the alternatives with the base case, dredging in the Folly River borrow area (Alternative 1) causes approximately 10\% less material loss. For Alternatives 2 and 3, the volume changes are very close to that for the base case, and the differences in volume changes among those cases are less than $1 \%$.

The volume changes in Table 4-10 also show net sediment loss along the shoreline of Kiawah Island. Large material losses occur on the southeast and the east side. Comparing with the loss in those areas, only $25 \%-30 \%$ of material loss occurs on the south side. Among three alternatives, dredging in the Stono Inlet Throat borrow area has relatively a large impact on sediment erosion in the nearshore area of the island. This alternative results in $6 \%$ more sediment volume loss on the southeast side of the island.

\subsection{A typical year (2018)}

Six selected locations, S1 to S6, within the actual dredged areas and near Folly Beach are shown in Figure 4-33. Time series of the calculated waves, current, and sediment transport are examined and compared between the base case and each of the alternative cases at those locations for the 2018 simulation. Morphology and volume changes in the borrow areas and nearshore in front of Folly Beach are obtained at the end of the simulation. 
Figure 4-33. Selected locations within the five borrow areas and nearshore Folly Beach.

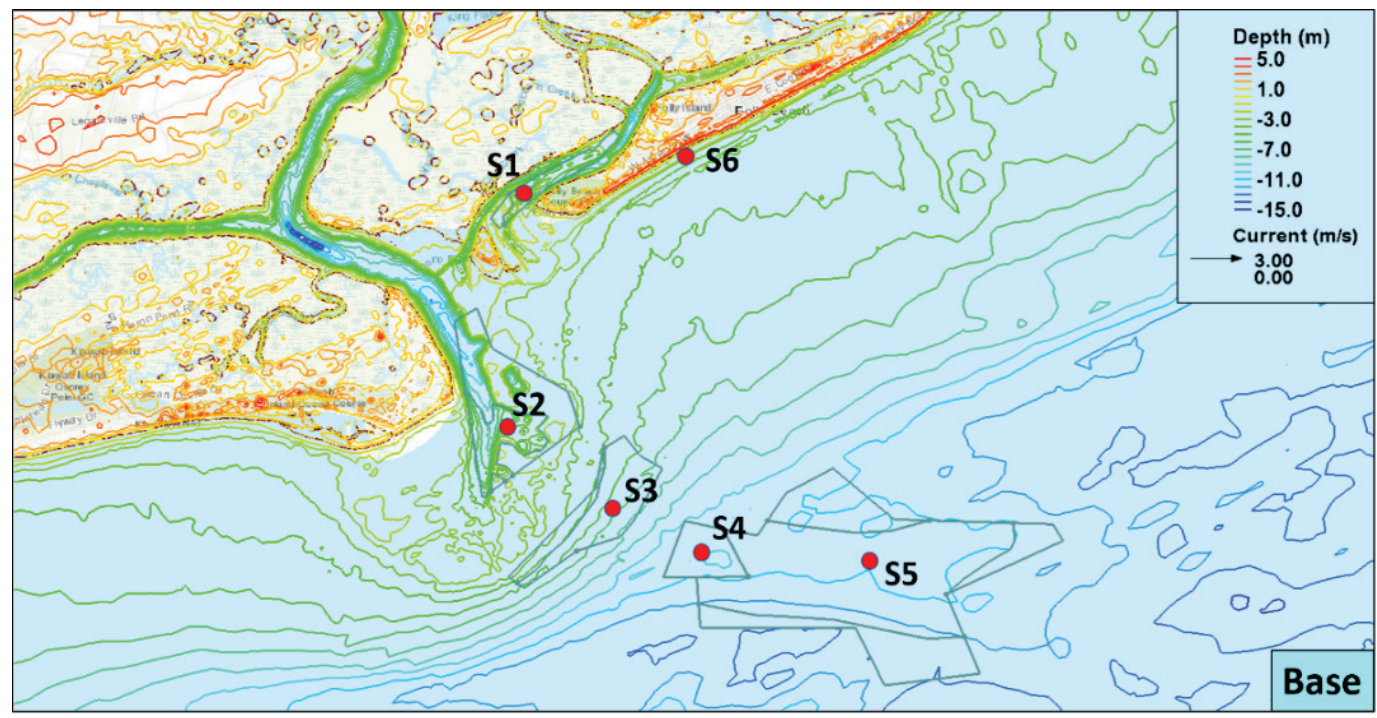

\subsubsection{Waves}

Figure 4-34 to Figure 4-39 show that several events occurred in 2018, mostly in January and December. Significant wave heights decreased from above $3 \mathrm{~m}$ (9.84 ft) in the offshore borrow areas ( 44 and $\left.\mathrm{S}_{5}\right)$ to less than $1 \mathrm{~m}$ (3.28 ft) in the Folly River borrow areas (S1). In transitional areas, significant wave heights decreased from approximately $3 \mathrm{~m}$ $(9.84 \mathrm{ft})$ in the Stono Ebb Shoal 1 borrow area $(\mathrm{S} 3)$ to $2 \mathrm{~m}(6.56 \mathrm{ft})$ in the Stono Inlet Throat borrow area (S2). The nearshore Folly Beach area (S6) is located in the break zone. In this area, significant wave heights were less than $2 \mathrm{~m}(6.56 \mathrm{ft})$. 
Figure 4-34. Comparison of significant wave heights between (a) base case and (b) Alternative 1 at S1 within the Folly River borrow area in 2018.

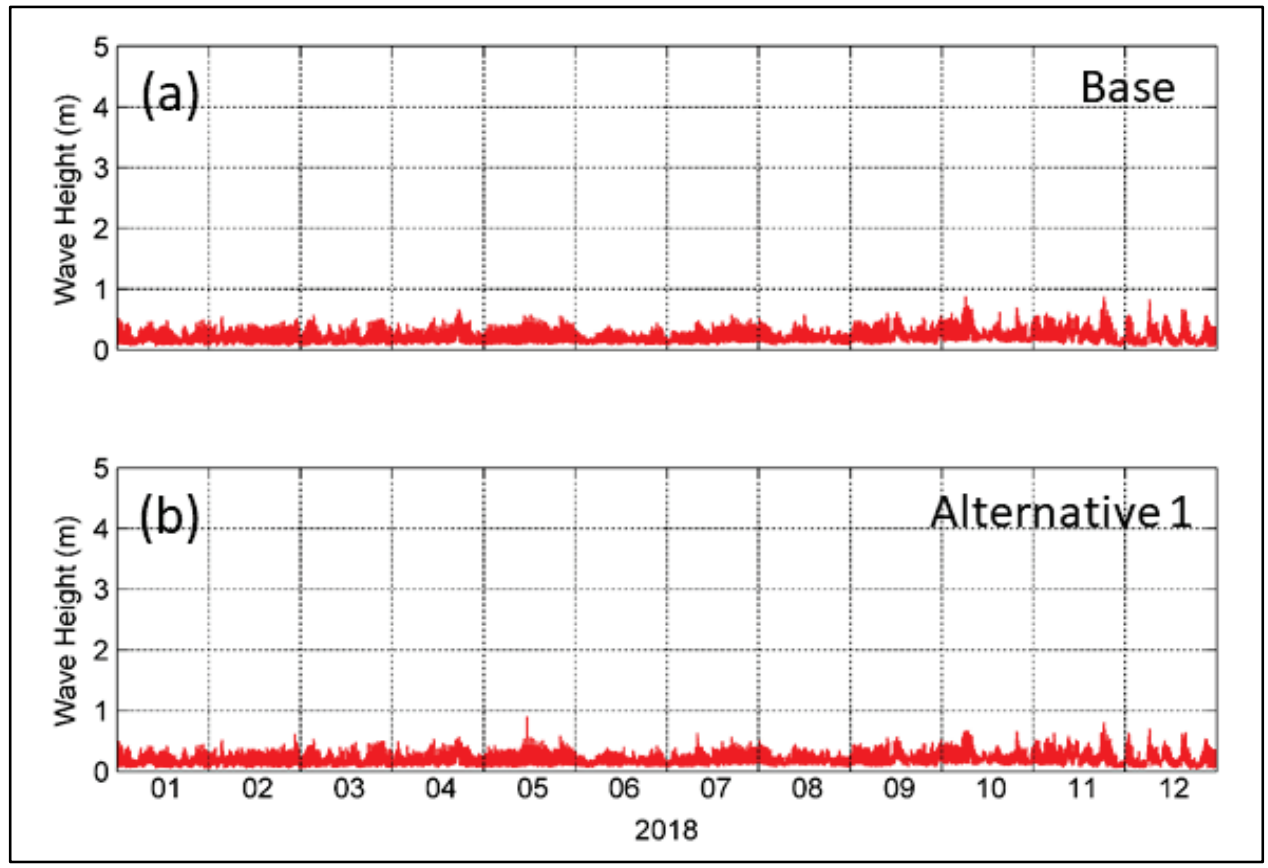

Figure 4-35. Comparison of significant wave heights between (a) base case and (b) Alternative 2 at $\$ 2$ within the Stono Inlet Throat borrow area in 2018.

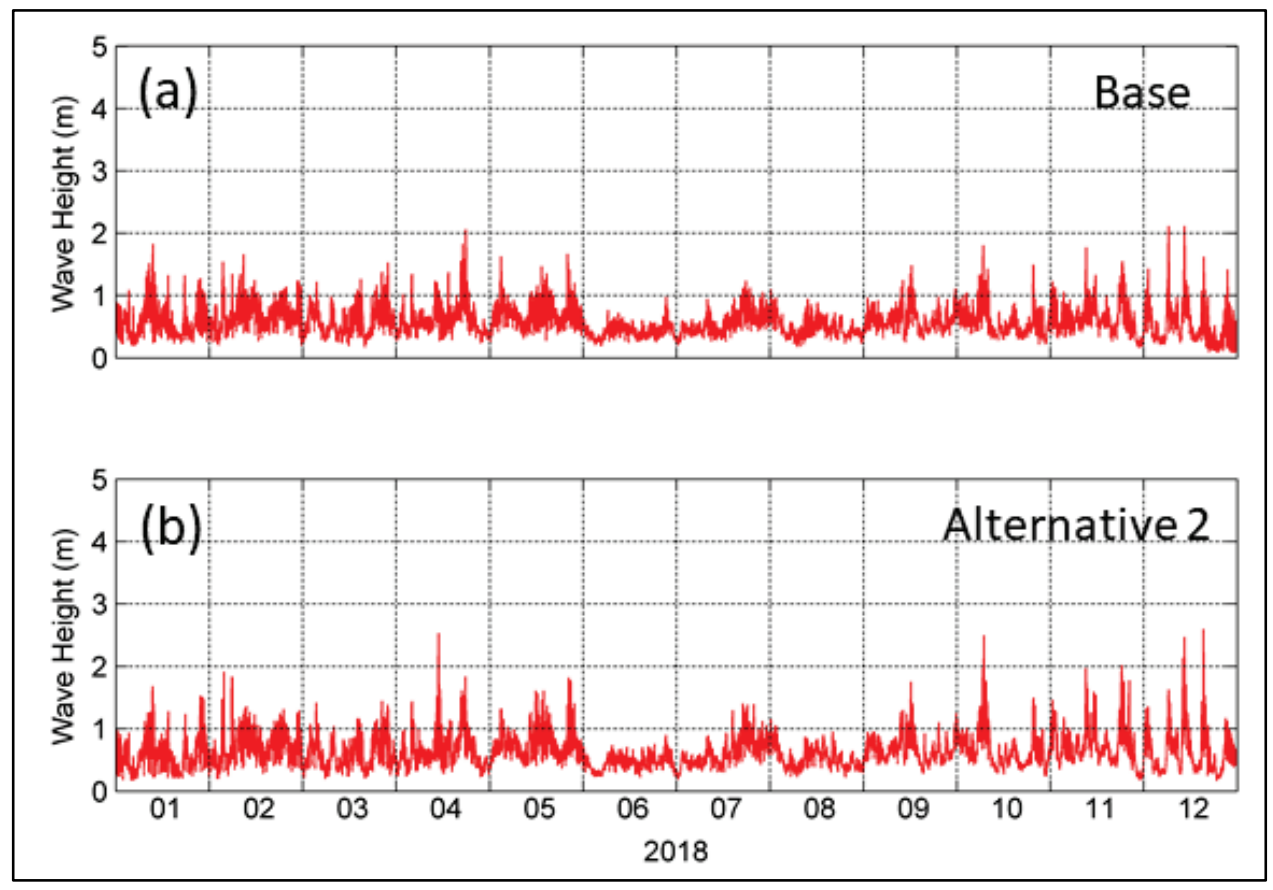


Figure 4-36. Comparison of significant wave heights between (a) base case and (b) Alternative 3 at S3 within the Stono Ebb Shoal 1 borrow area in 2018.

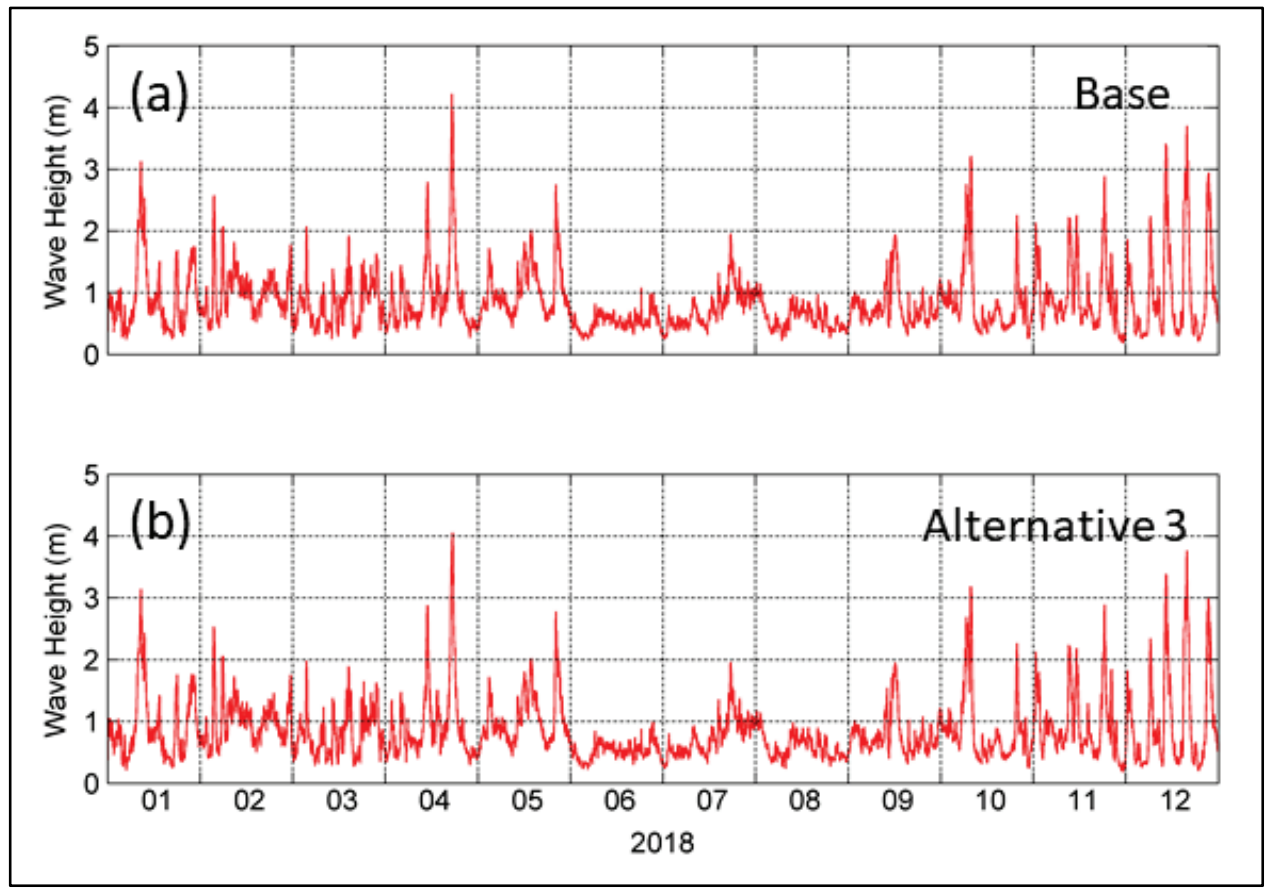

Figure 4-37. Comparison of significant wave heights between (a) base case and (b) Alternative 4 at S4 within the Stono Ebb Shoal 2 borrow area in 2018.

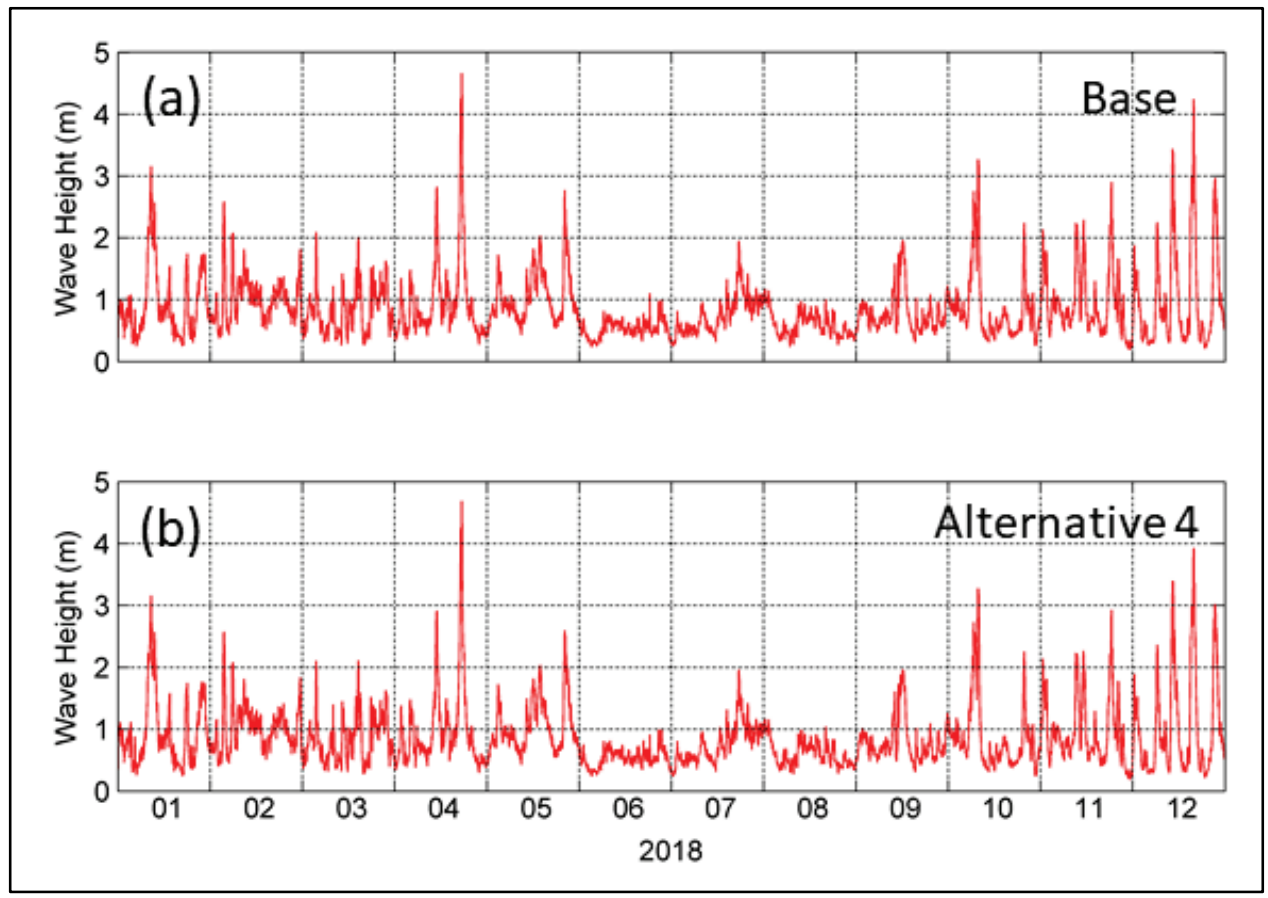


Figure 4-38. Comparison of significant wave heights between (a) base case and (b) Alternative 5 at S5 within the Stono Inlet borrow area in 2018.

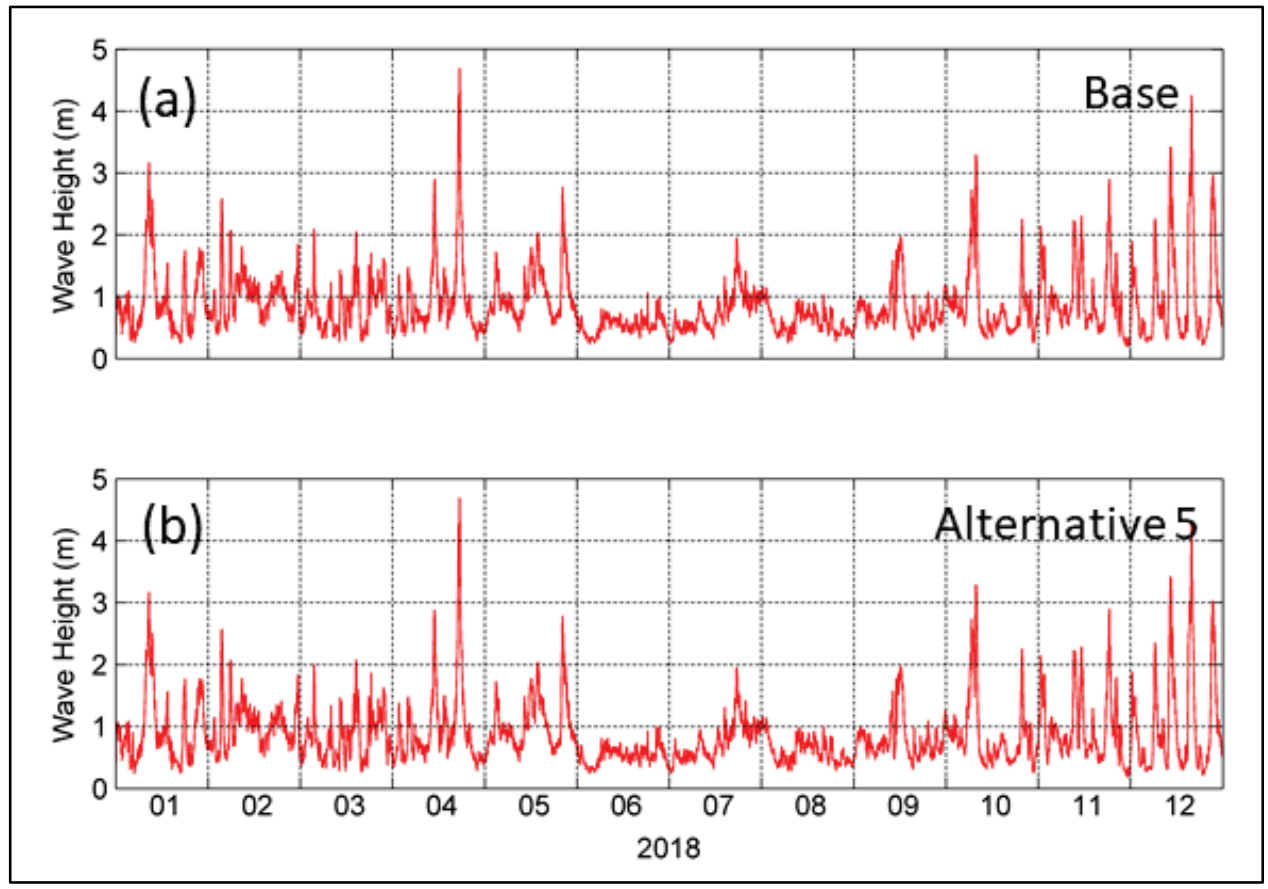

Figure 4-39. Comparison of significant wave heights between (a) base case and (b) Alternative 1 at S6 in the nearshore Folly Beach area in 2018.

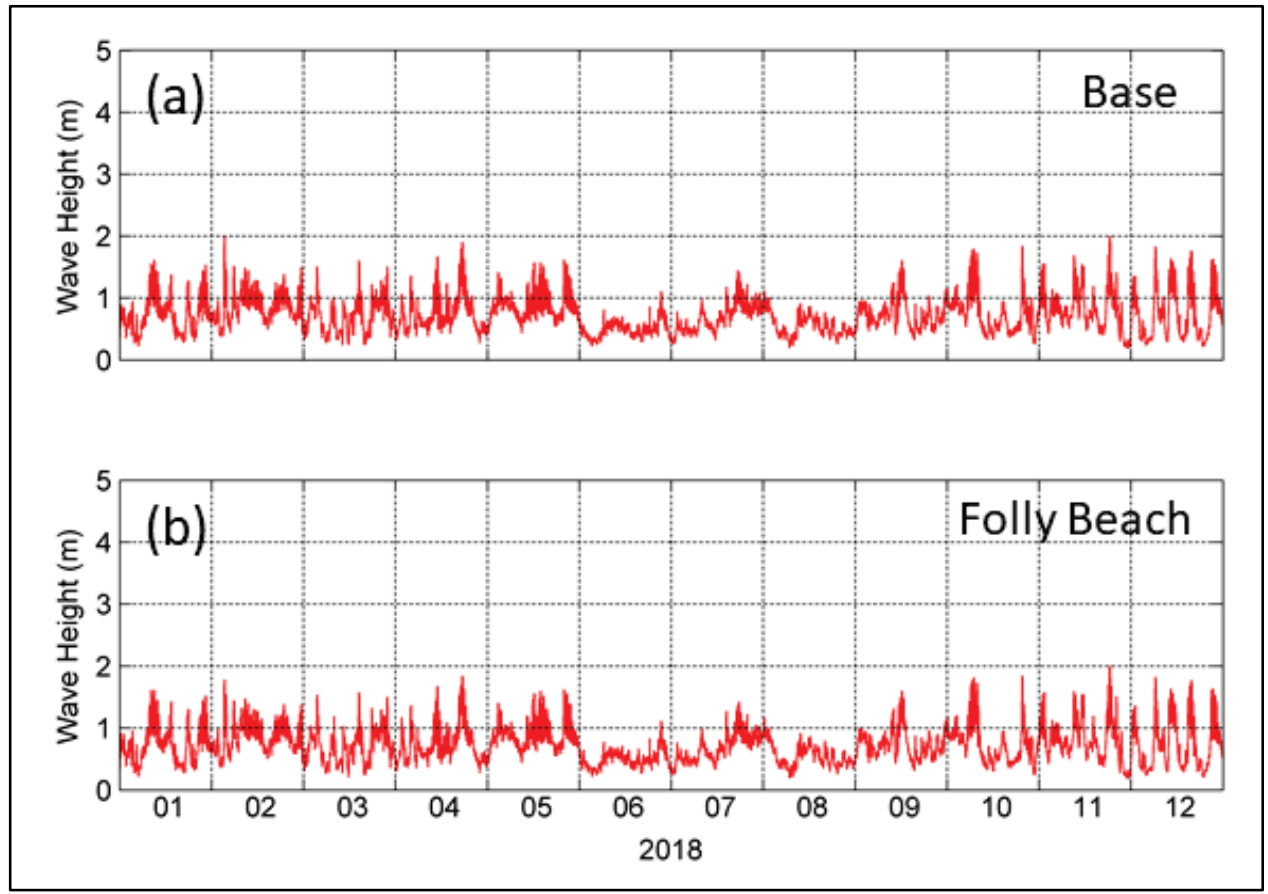


Comparing the base case with the alternative cases, wave heights do not change much due to sand removal in the deeper borrow areas ( $\mathrm{S}_{3}$ to $\mathrm{S}_{5}$ ). Because the original depth is small (approximately $4.0 \mathrm{~m}$ [13.1 ft]), sand removal in the Stono Inlet Throat area causes increase in peak wave heights. Figure 4-39 shows the comparison between the base case and Alternative 1 in the nearshore Folly Beach area at S6. Because no dredge activity happened at the location, wave heights between the two cases are very close over the year (Table 4-11).

Table 4-11. Annual averaged wave heights, current speeds, and sediment transport rates for the base and the alternative cases in the borrow areas and the nearshore Folly Beach area.

\begin{tabular}{|l|l|l|l|l|l|l|}
\hline & \multicolumn{3}{|l|}{} & \multicolumn{2}{l|}{} & \multicolumn{2}{l|}{ Sediment Transport } \\
\cline { 2 - 8 } Area & Wave Height $(\mathrm{m})$ & \multicolumn{2}{l|}{ Current Speed $(\mathrm{m} / \mathrm{s})$} & \multicolumn{2}{l|}{ Rate $(\mathrm{kg} /(\mathrm{m} . \mathbf{s}))$} \\
\hline & Base & Alternative & Base & Alternative & Base & Alternative \\
\hline Folly River (S1) & 0.241 & 0.219 & 0.241 & 0.148 & 0.148 & 0.050 \\
\hline $\begin{array}{l}\text { Stono Inlet } \\
\text { Throat (S2) }\end{array}$ & 0.591 & 0.637 & 0.239 & 0.254 & 0.219 & 0.336 \\
\hline $\begin{array}{l}\text { Stono Ebb Shoal } \\
\text { 1 (S3) }\end{array}$ & 0.837 & 0.835 & 0.107 & 0.103 & 0.098 & 0.086 \\
\hline $\begin{array}{l}\text { Stono Ebb Shoal } \\
\text { 2 (S4) }\end{array}$ & 0.844 & 0.853 & 0.077 & 0.068 & 0.064 & 0.058 \\
\hline $\begin{array}{l}\text { Stono Inlet } \\
\text { Throat (S5) }\end{array}$ & 0.849 & 0.851 & 0.063 & 0.060 & 0.051 & 0.050 \\
\hline Folly Beach (S6) & 0.721 & 0.720 & 0.102 & 0.101 & 0.094 & 0.094 \\
\hline
\end{tabular}

\subsubsection{Current}

Figure 4-40 shows a snapshot of the depth-averaged flood and ebb current fields for the base case on 27 February 2018 at 22:00 and 28 February 2018 04:00 GMT, respectively. The maximum current speed is approximately $1.0-1.5 \mathrm{~m} / \mathrm{s}(3.28-4.92 \mathrm{ft} / \mathrm{s})$ in the Stono River channel. During both flood and ebb current, the current speeds are relatively strong in the Folly River, Stono Inlet Throat, and Stono Ebb Shoal 1 borrow areas and weak in the Stono Ebb Shoal 2 and Stono Inlet borrow areas. The longshore current near Folly Beach shows flow direction from northeast to southwest periods although the current speed is much smaller during the ebb period. 
Figure 4-40. Calculated depth-averaged (a) flood and (b) ebb currents on 27 February 2018 at 22:00 and 28 February 2018 at 04:00 GMT, respectively.

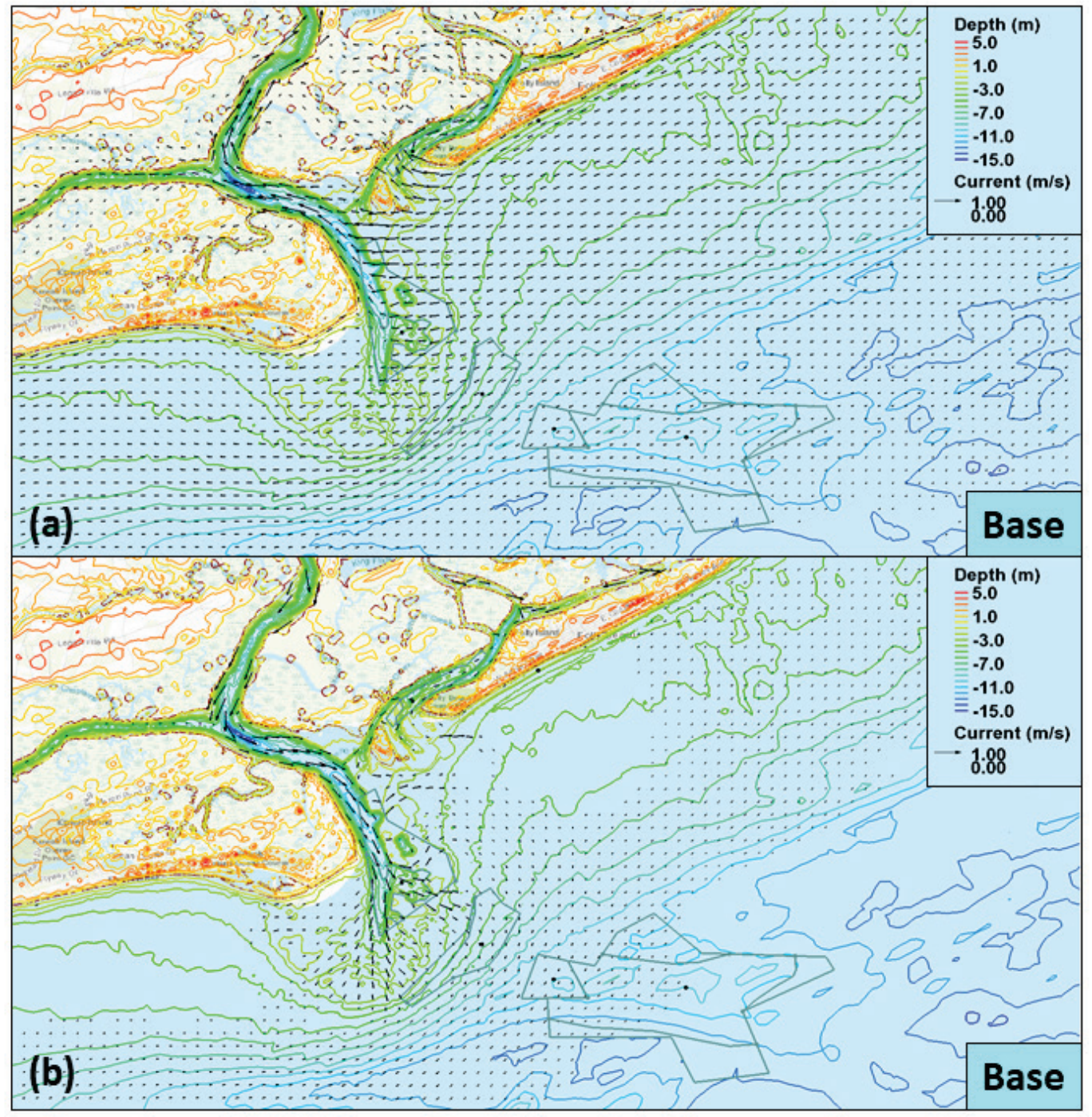

Figure 4-41 to Figure 4-46, and Table 4-11 show that the nearshore Folly River (S1) and Stono Inlet Throat (S2) borrow areas have relatively strong currents with the peak speed above $0.8 \mathrm{~m} / \mathrm{s}(2.62 \mathrm{ft} / \mathrm{s})$. In the offshore borrow areas ( 44 and $\left.\mathrm{S}_{5}\right)$, the current speeds are generally less than $0.2 \mathrm{~m} / \mathrm{s}(0.66 \mathrm{ft} / \mathrm{s})$. The nearshore Folly Beach area (S6) has shallow water depths and is greatly impacted by coastal processes and meteorological conditions. The peak current speeds there can be above $0.8 \mathrm{~m} / \mathrm{s}(2.62 \mathrm{ft} / \mathrm{s})$ during this annual simulation period. 
Figure 4-41. Comparison of current speeds between (a) base case and (b) Alternative 1 at S1 within the Folly River borrow area in 2018.

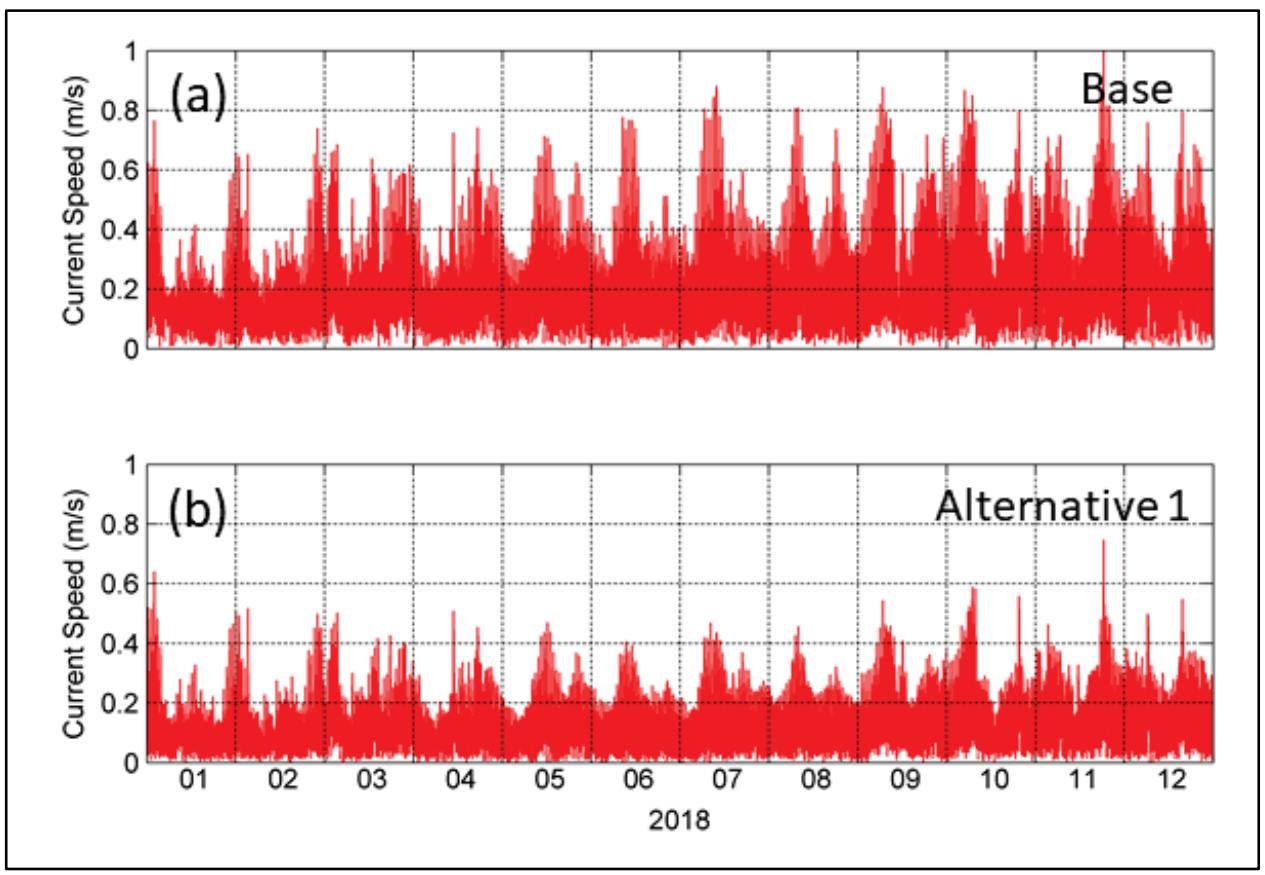

Figure 4-42. Comparison of current speeds between (a) base case and (b) Alternative 2 at S2 within the Stono Inlet Throat borrow area in 2018.

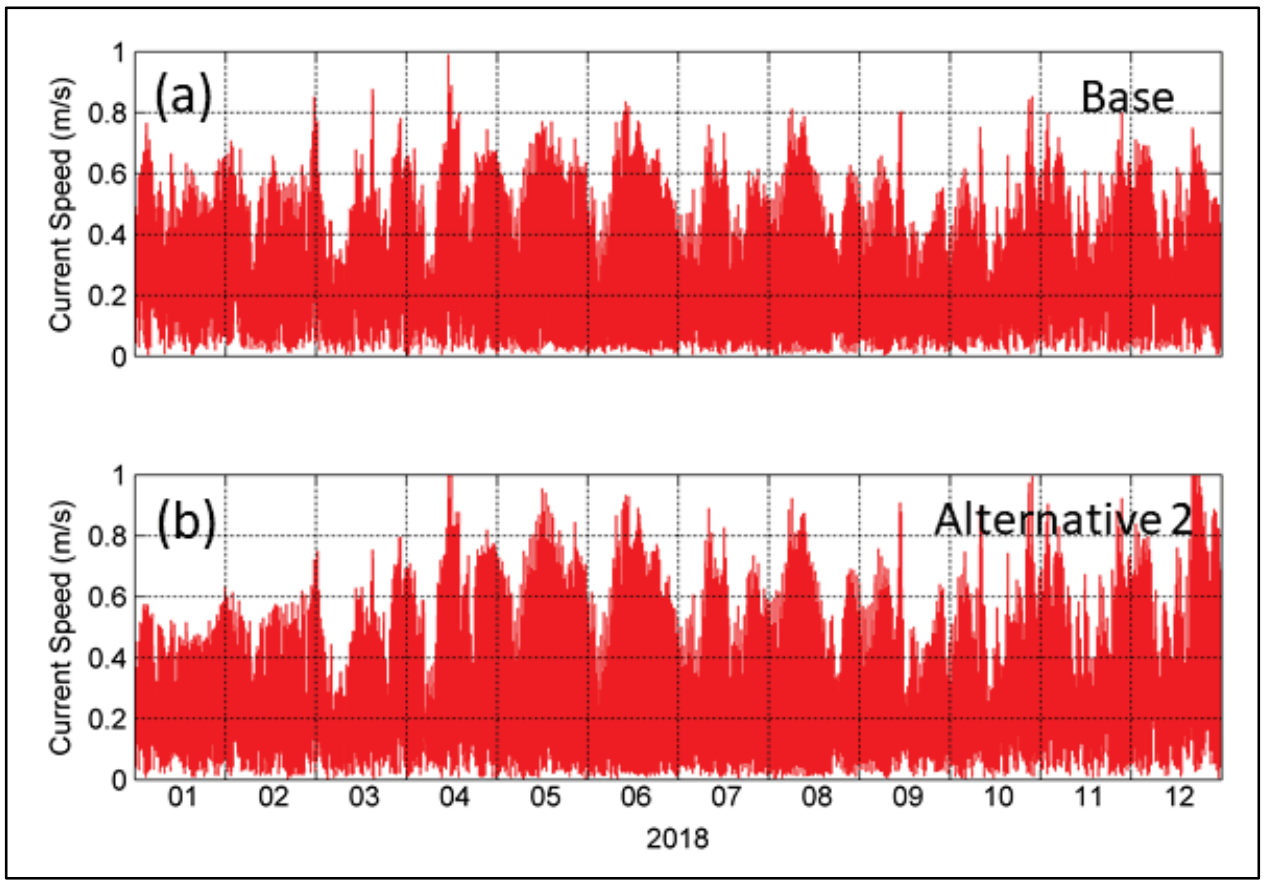


Figure 4-43. Comparison of current speeds between (a) base case and (b) Alternative 3 at S3 within the Stono Ebb Shoal 1 borrow area in 2018.

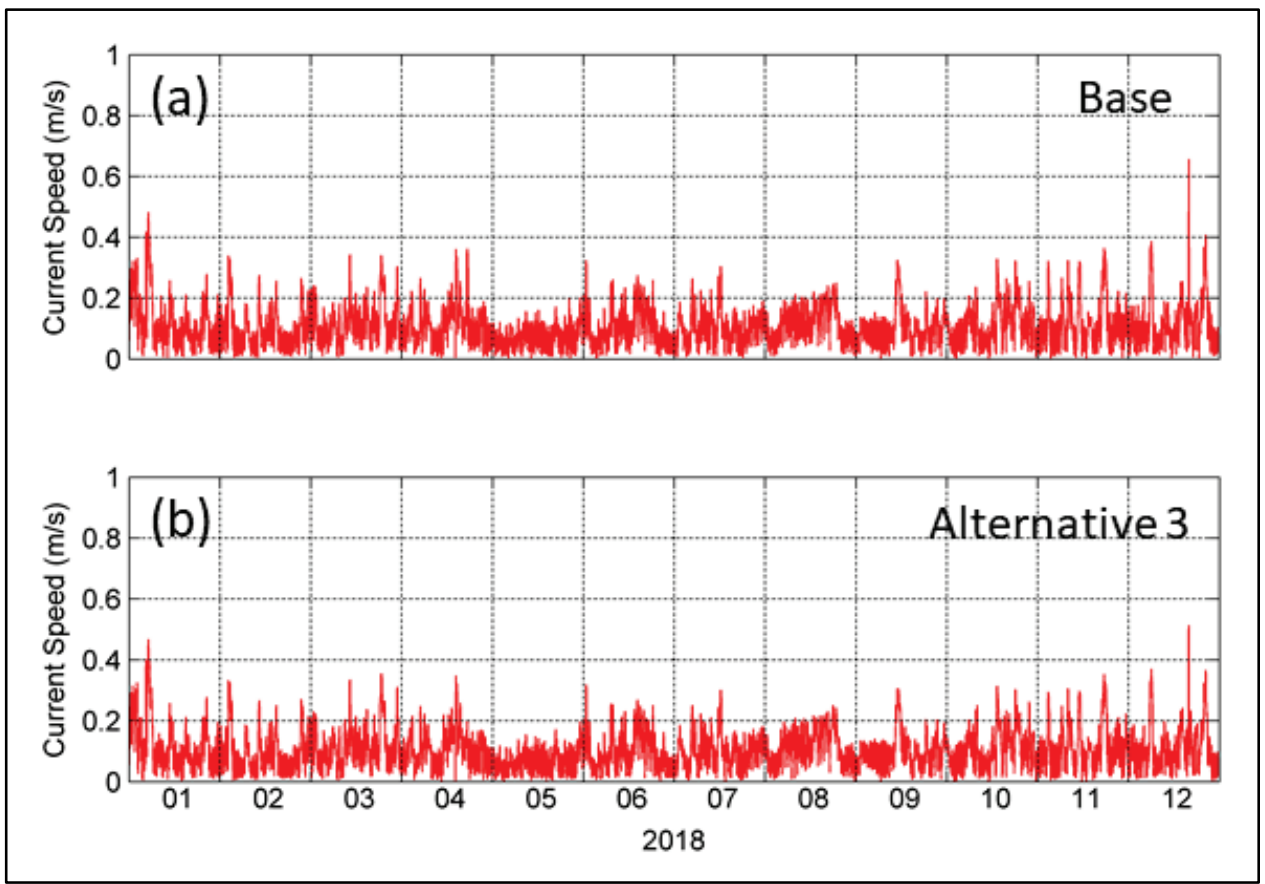

Figure 4-44 Comparison .of current speeds between (a) base case and (b) Alternative 4 at S4 within the Stono Ebb Shoal 2 borrow area in 2018.

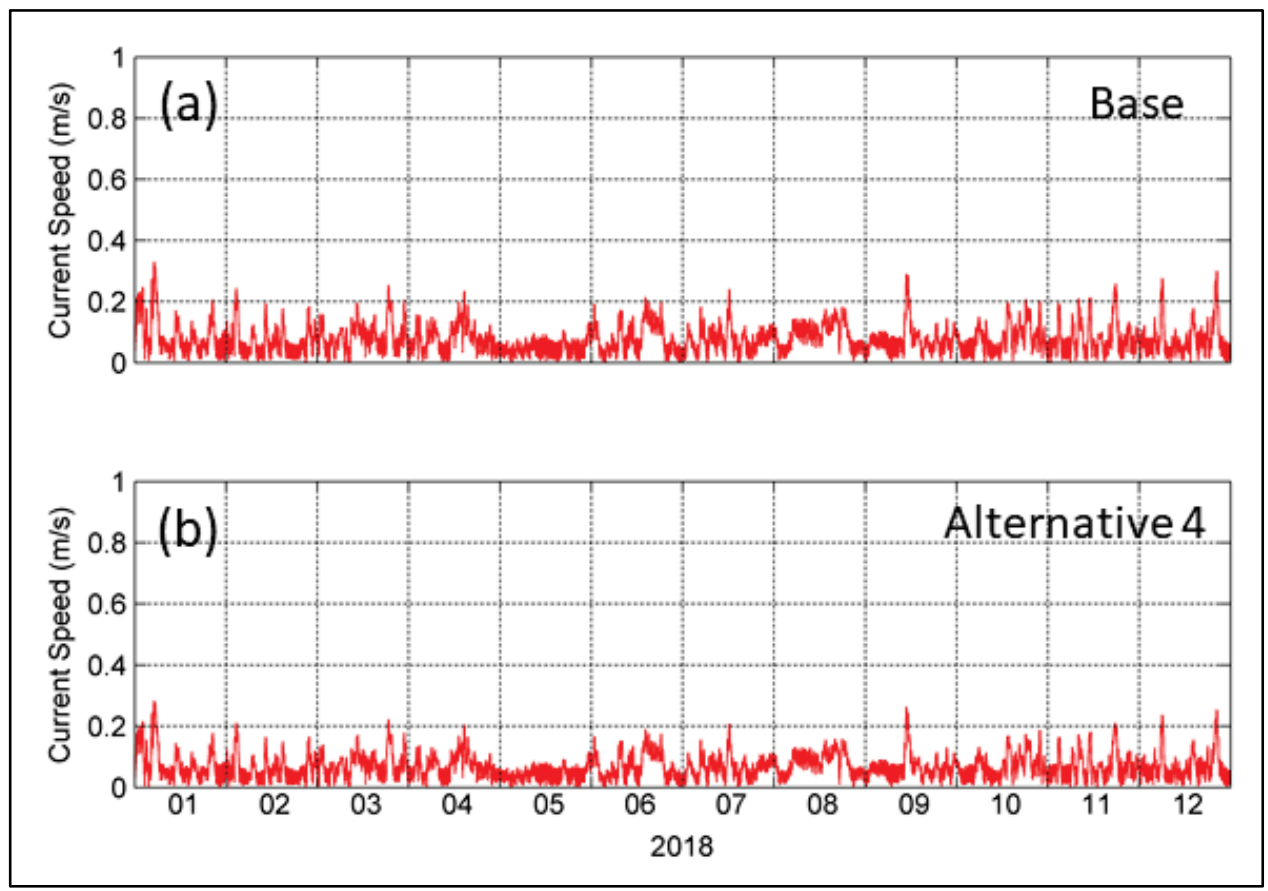


Figure 4-45. Comparison of current speeds between (a) base case and

(b) Alternative 5 at S5 within the Stono Inlet borrow area in 2018.

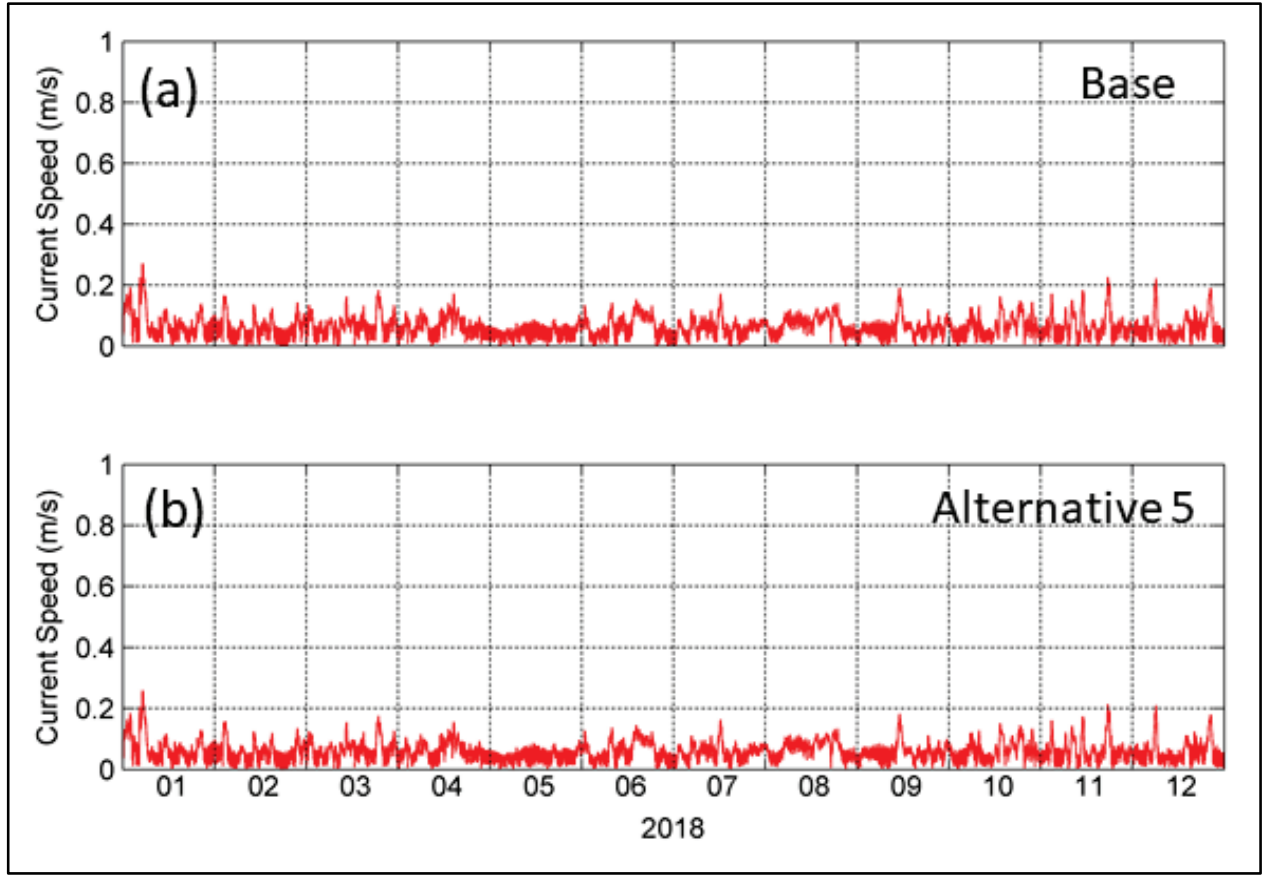

Figure 4-46 Comparison of current speeds between (a) base case and (b) Alternative 1 at S6 within the nearshore Folly Beach area in 2018.

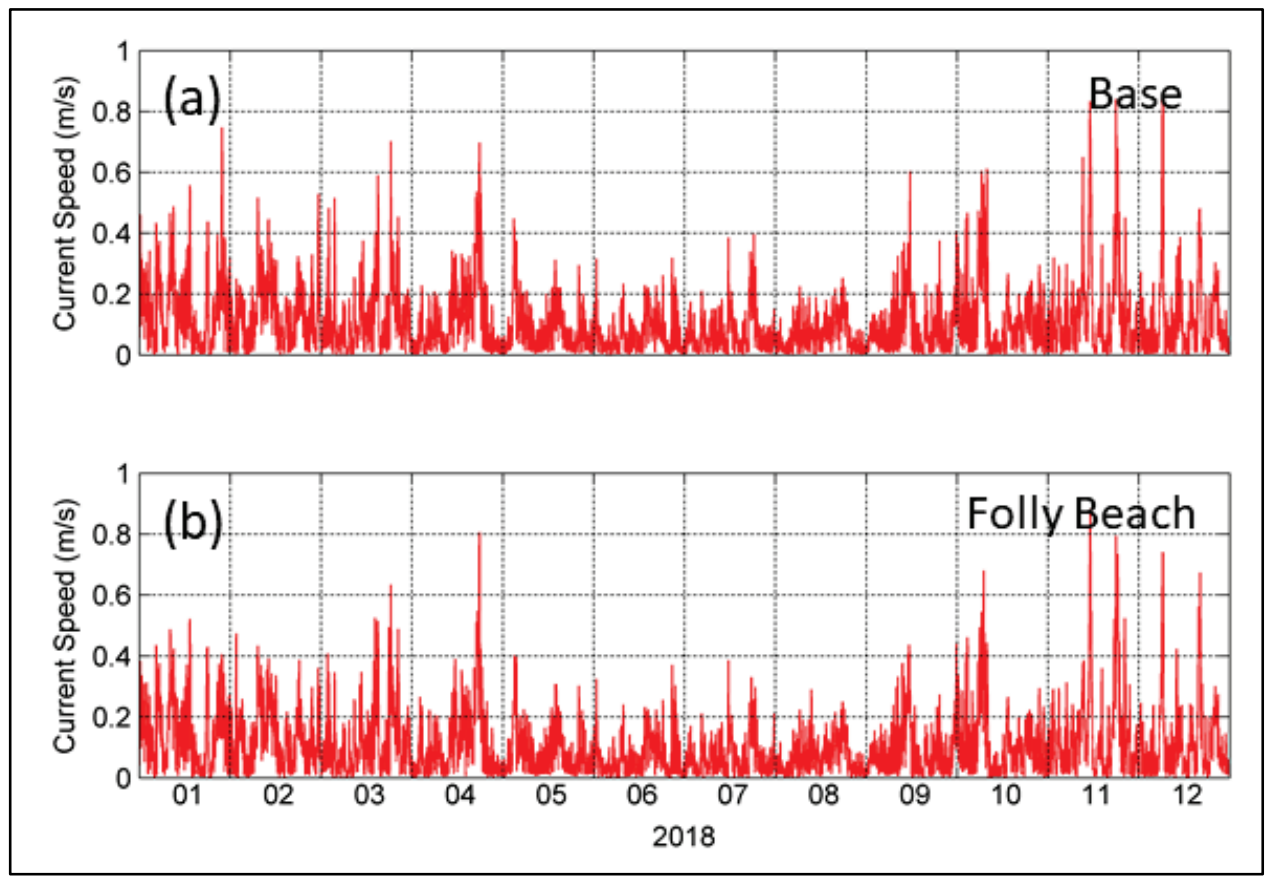

Depth-averaged currents are closely associated with water depth changes. The Folly River borrow area was deepened from approximately an average depth of $2.5 \mathrm{~m}$ to $7.5 \mathrm{~m}$ (8.2 to $24.61 \mathrm{ft} / \mathrm{s}$ ), and therefore the largest 
current speed changes can be seen in Figure 4-41. The offshore areas ( $\mathrm{S}_{3}$ to $\mathrm{S}_{5}$ ) do not show significant changes in current speed because the original water depths are large and sand removal does not require large depth change due to the size of the borrow areas. Without sand borrowing in the nearshore Folly Beach area, Figure 4-46 shows the current speed changes through the year, which is probably due to depth changes related to sediment movement along the shore.

\subsubsection{Sediment transport}

Corresponding to wave and current forcing, the time series of sediment transport rates and annual averages are shown in Figure 4-47 to Figure 4-52, and Table 4-11. Similar to current variations in Figure 4-41 to Figure 4-46, the nearshore Folly River (S1), Stono Inlet Throat (S2) borrow areas, and Folly Beach area (S6) have relatively large sediment transport with the peak rate above $3 \mathrm{~kg} /(\mathrm{m} \cdot \mathrm{s})$. Comparing with those areas, the offshore sites in the Stono Ebb Shoal $2\left(\mathrm{~S}_{4}\right)$ and the Stono Inlet $\left(\mathrm{S}_{5}\right)$ borrow areas show much smaller sediment transport rates, mostly less than $0.4 \mathrm{~kg} /(\mathrm{m} \cdot \mathrm{s})$.

Figure 4-47. Comparison of sediment transport rates between (a) base case and (b) Alternative 1 at S1 within the Folly River borrow area in 2018.

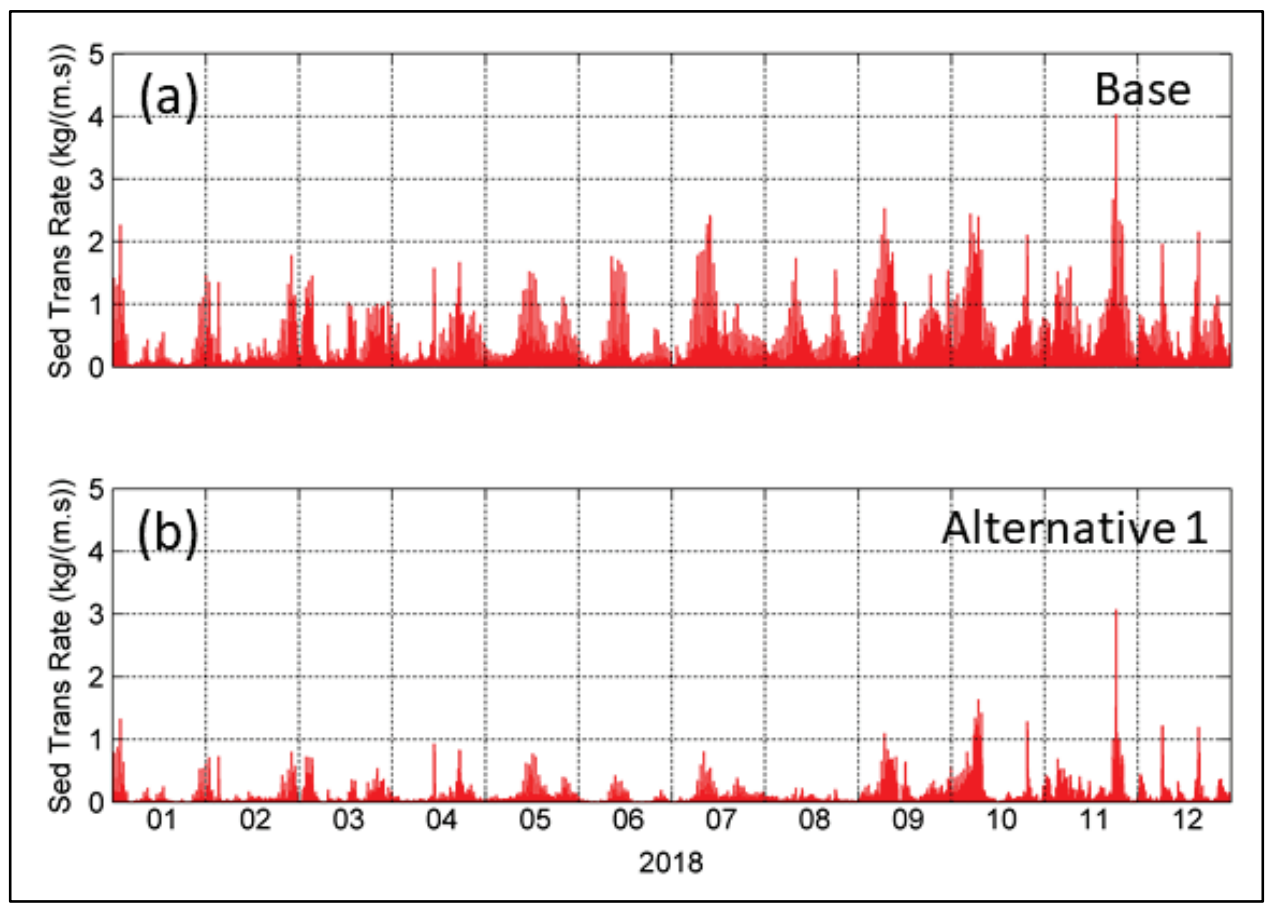


Figure 4-48. Comparison of sediment transport rates between (a) base case and (b) Alternative 2 at S2 within the Stono Inlet Throat borrow area in 2018.

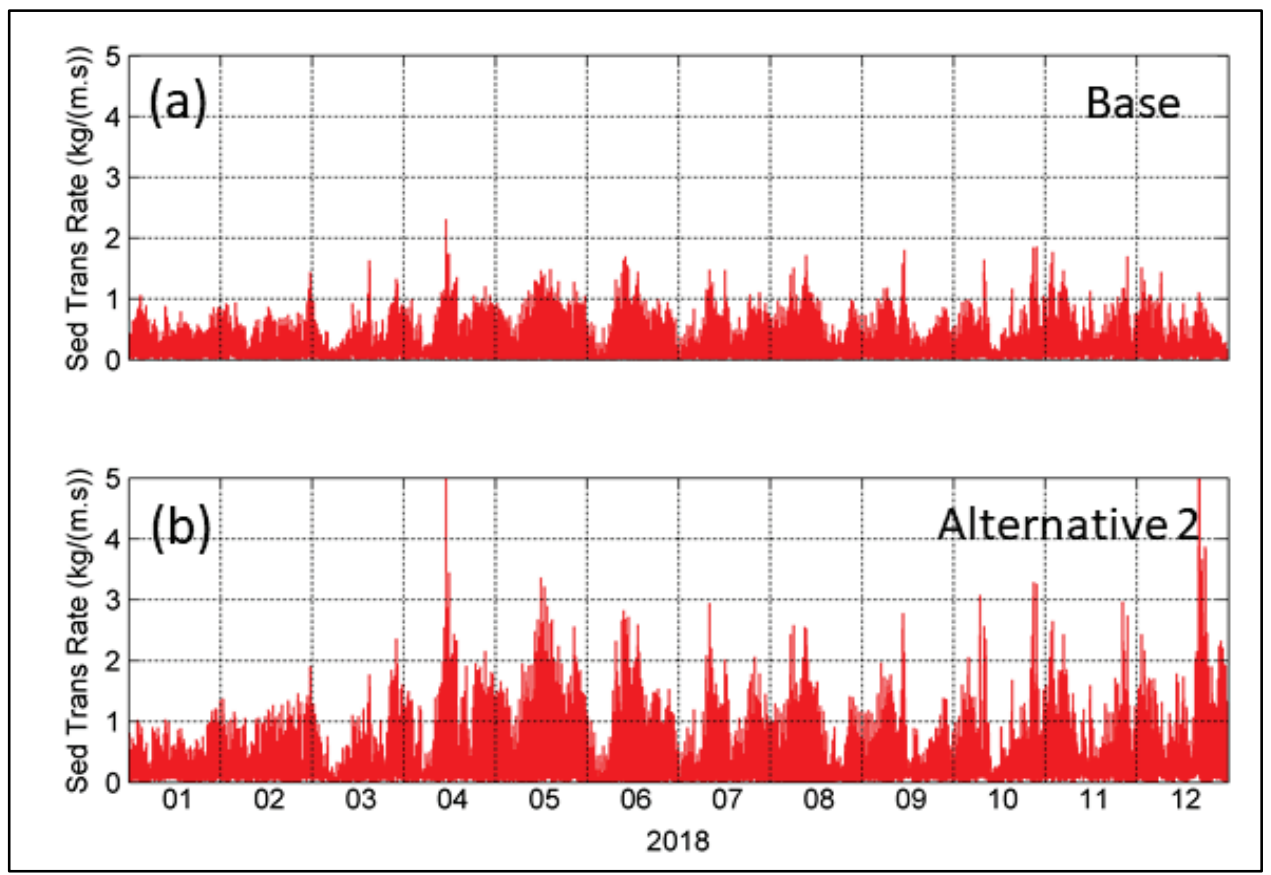

Figure 4-49. Comparison of sediment transport rates between (a) base case and (b) Alternative 3 at S3 within the Stono Ebb Shoal 1 borrow area in 2018.

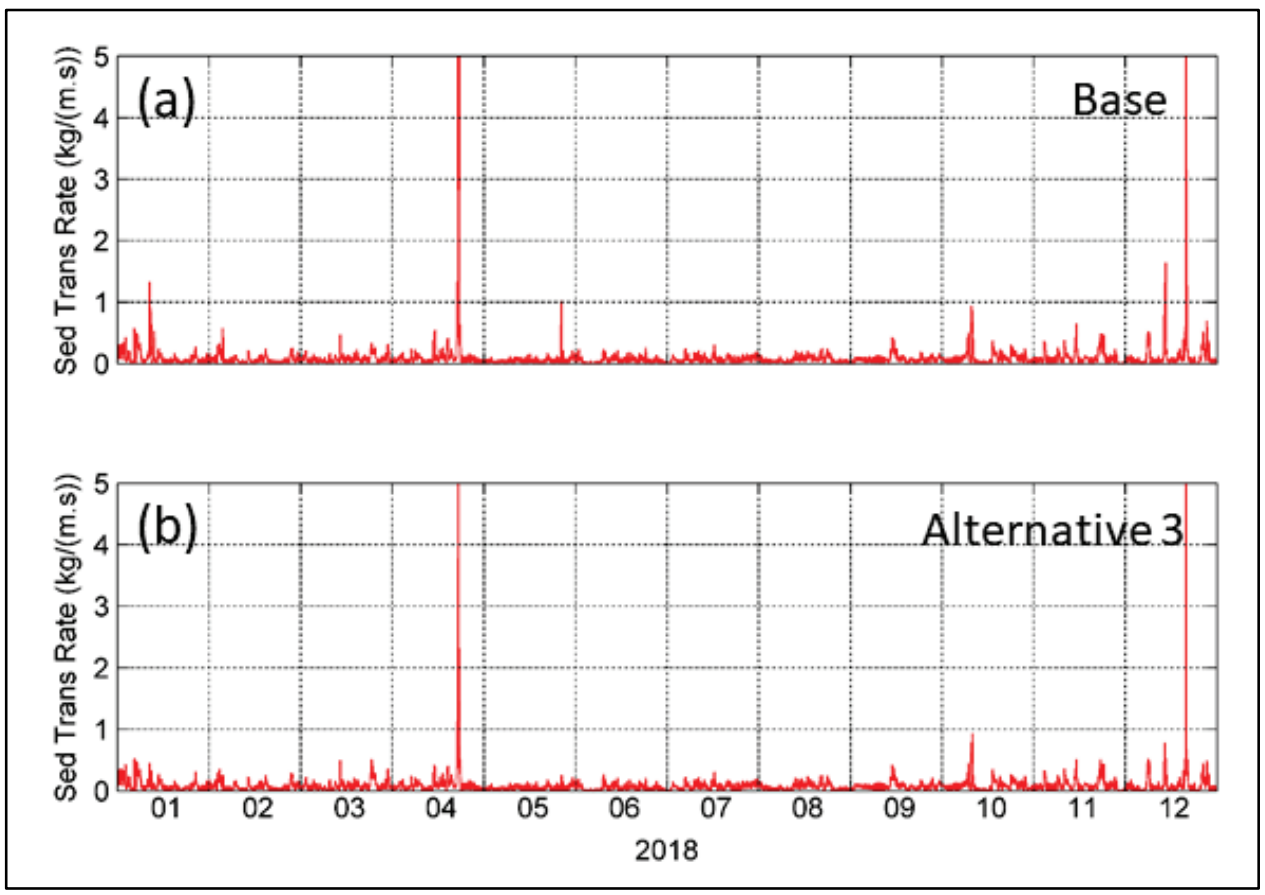


Figure 4-50. Comparison of sediment transport rates between (a) base case and (b) Alternative 4 at S4 within the Stono Ebb Shoal 2 borrow area in 2018.

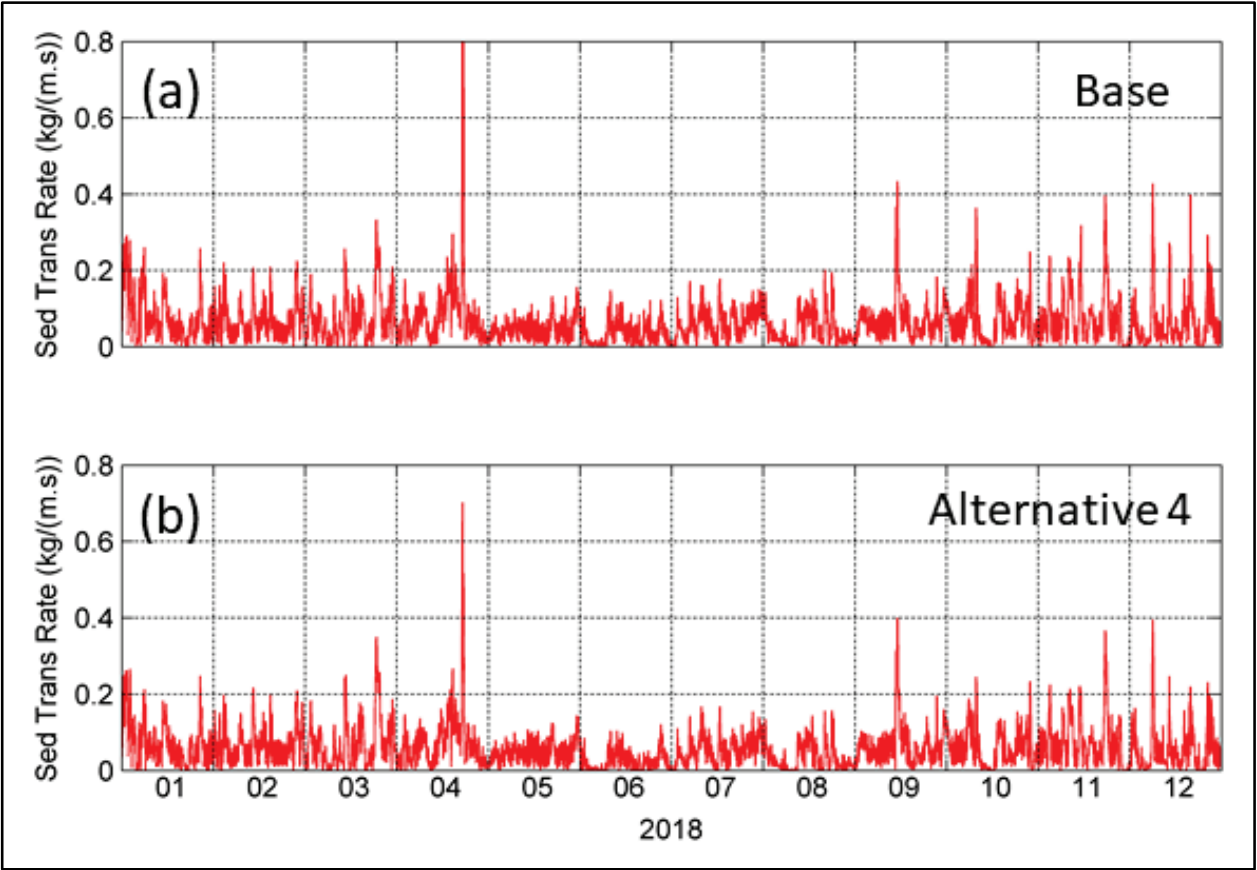

Figure 4-51. Comparison of sediment transport rates between (a) base case and (b) Alternative 5 at S5 within the Stono Inlet borrow area in 2018.

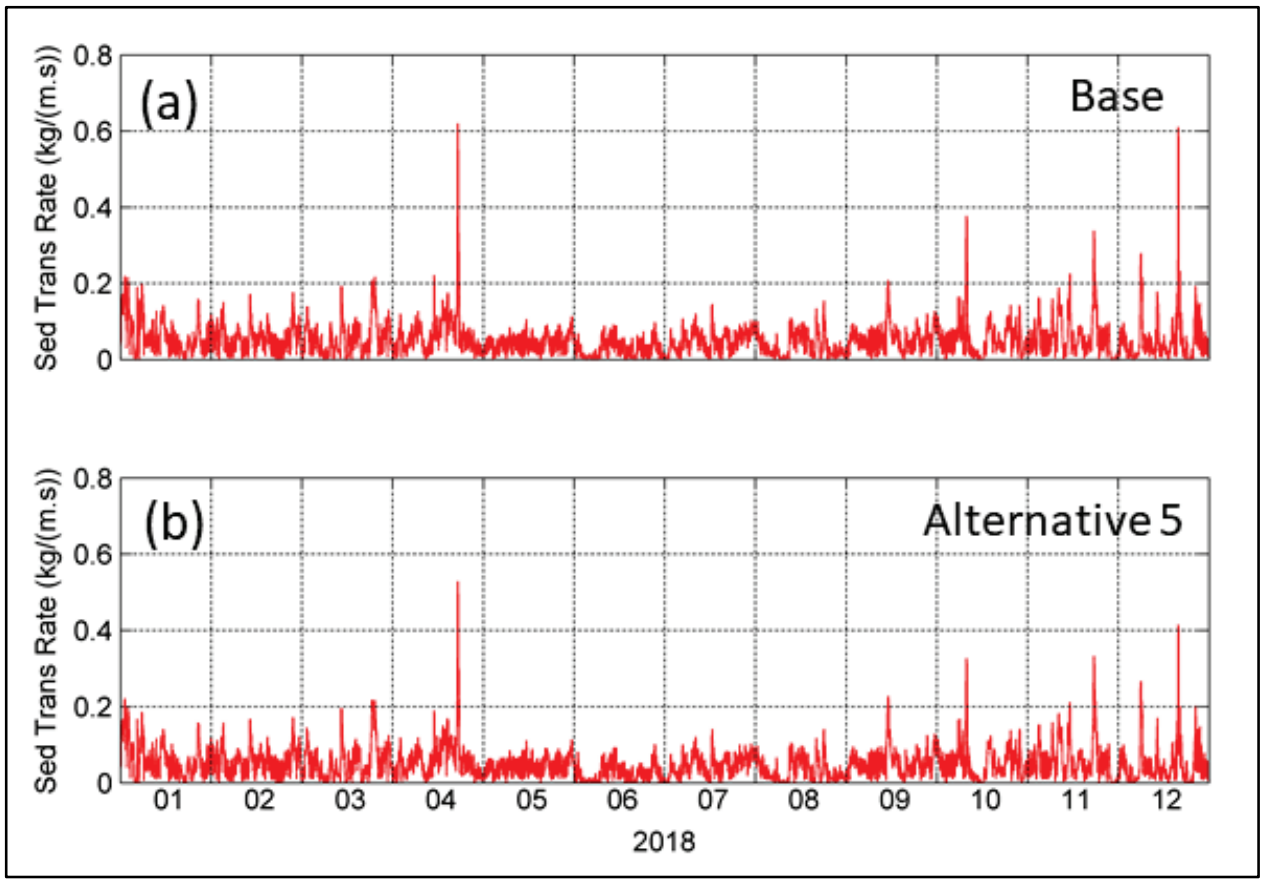


Figure 4-52. Comparison of sediment transport rates between (a) base case and (b) Alternative 1 at S6 in the nearshore Folly Beach area in 2018.

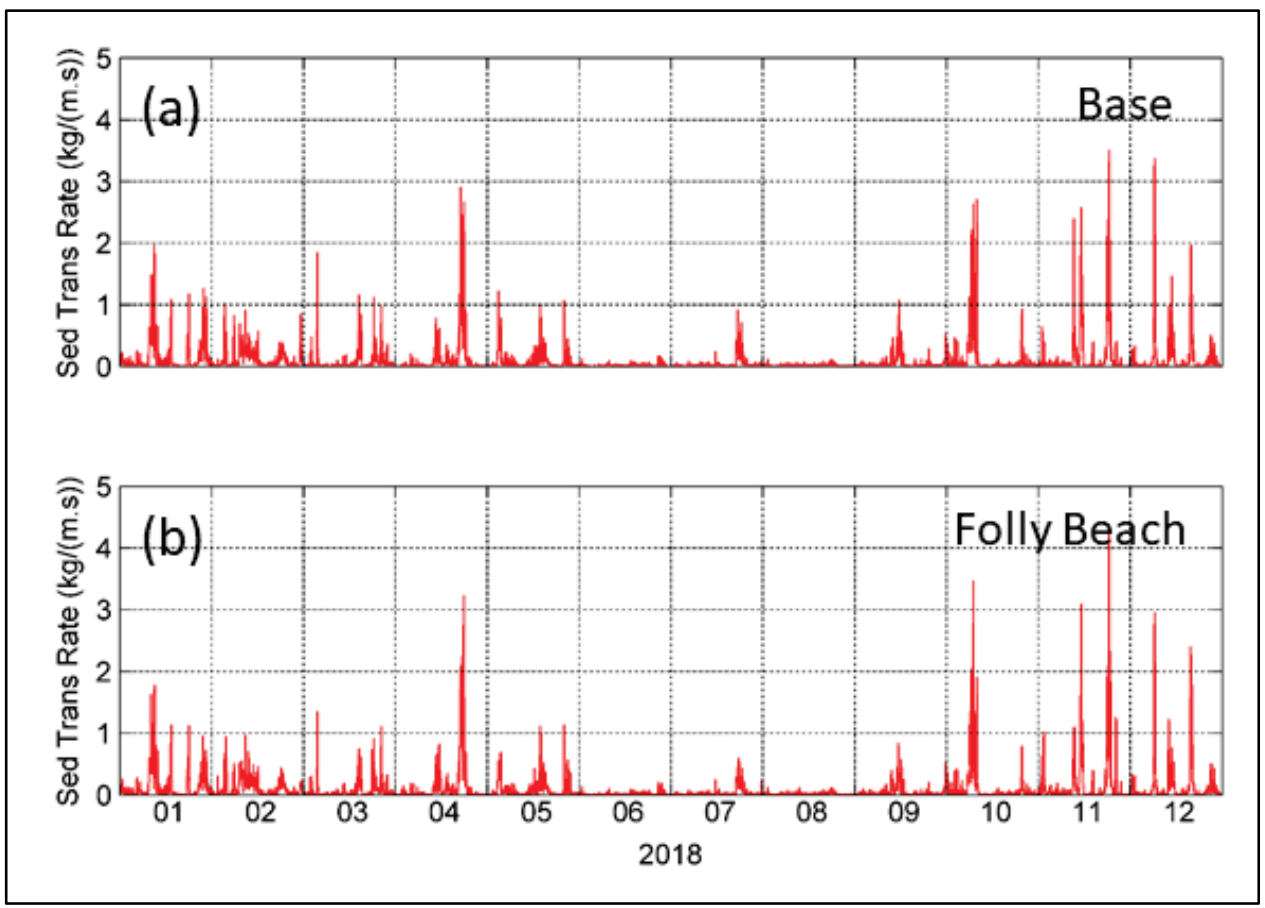

Current speeds and sediment transport rates have the greatest decrease in the Folly River borrow area (S1) (Figure 4-47). The offshore areas ( $\mathrm{S}_{3}$ to $\mathrm{S}_{5}$ ) do not show significant changes in sediment transport. The annual averaged transport rates are all less than $0.1 \mathrm{~kg} /(\mathrm{m} \cdot \mathrm{s})$ both in the base and the alternative cases (Table 4-11). Without sand borrowing sediment transport changes in the nearshore Folly Beach area (S6) respond to changes in water depth due to sediment erosion and deposition (Figure 4-52).

\subsubsection{Morphology change}

Annual morphology and volume changes within the five borrow areas and the nearshore Folly Beach area were calculated for the base and the alternative cases. For 2018, the changes were obtained by subtracting depth values at the end of simulation on 1 January 2019 at 00:00 from the initial depth values at the beginning of the simulation.

Comparisons of morphology changes before (base) and after (alternatives) sand removal from each of the borrow areas are shown in Figure 4-53 to Figure 4-57, respectively. The maximum erosion and deposition values within those areas are listed in Table 4-12. 
Figure 4-53. Comparison of morphology changes between (a) base case and (b) Alternative 1 within the Folly River borrow area in 2018. Warmer colors represent sediment accretion and cooler colors sediment erosion.

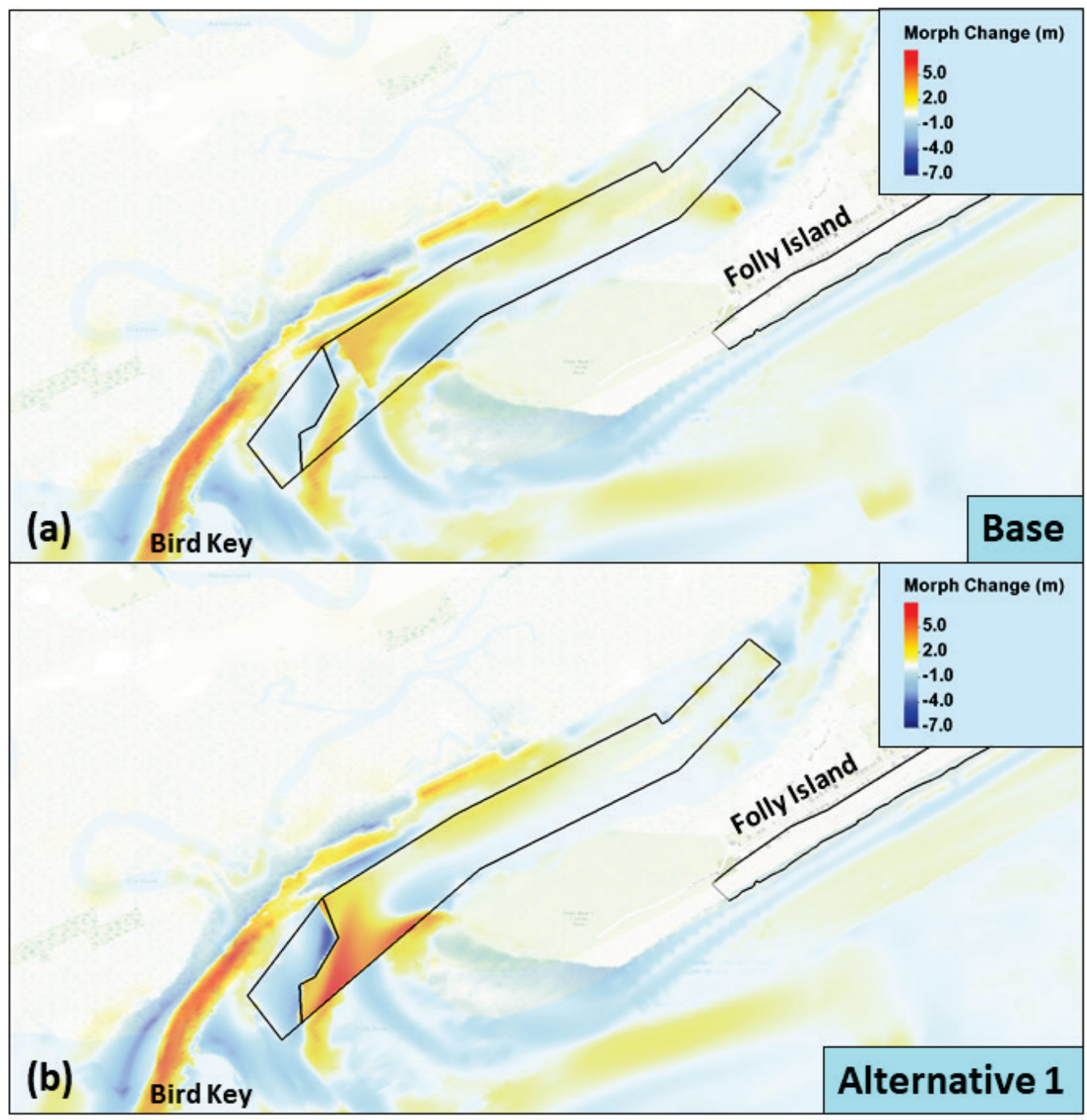


Figure 4-54. Comparison of morphology changes between (a) base case and (b) Alternative 2 within the Stono Inlet Throat borrow area in 2018. Warmer colors represent sediment accretion and cooler colors sediment erosion.

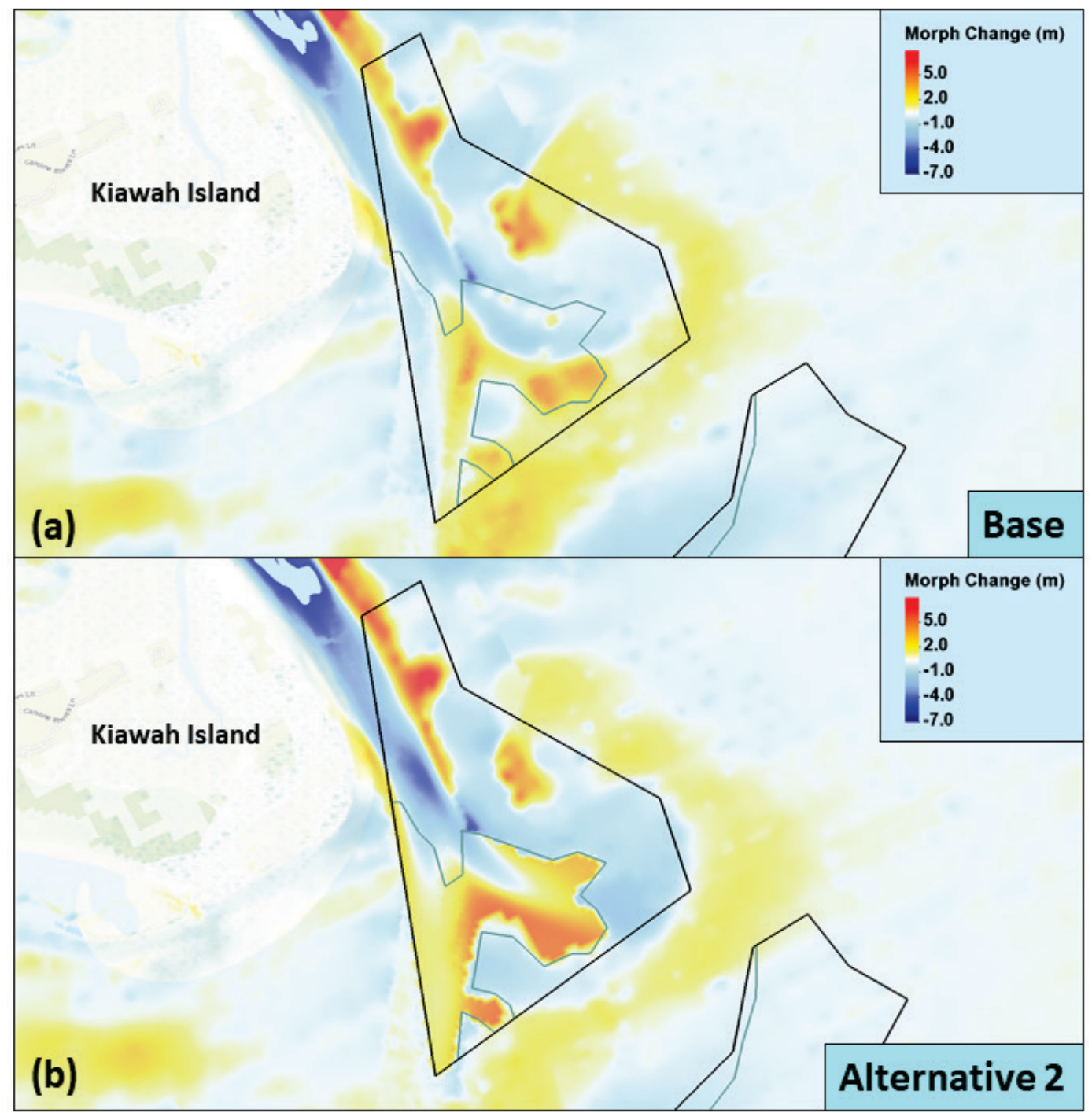


Figure 4-55. Comparison of morphology changes between (a) base case and (b) Alternative 3 within the Stono Ebb Shoal 1 borrow area in 2018. Warmer colors represent sediment accretion and cooler colors sediment erosion.

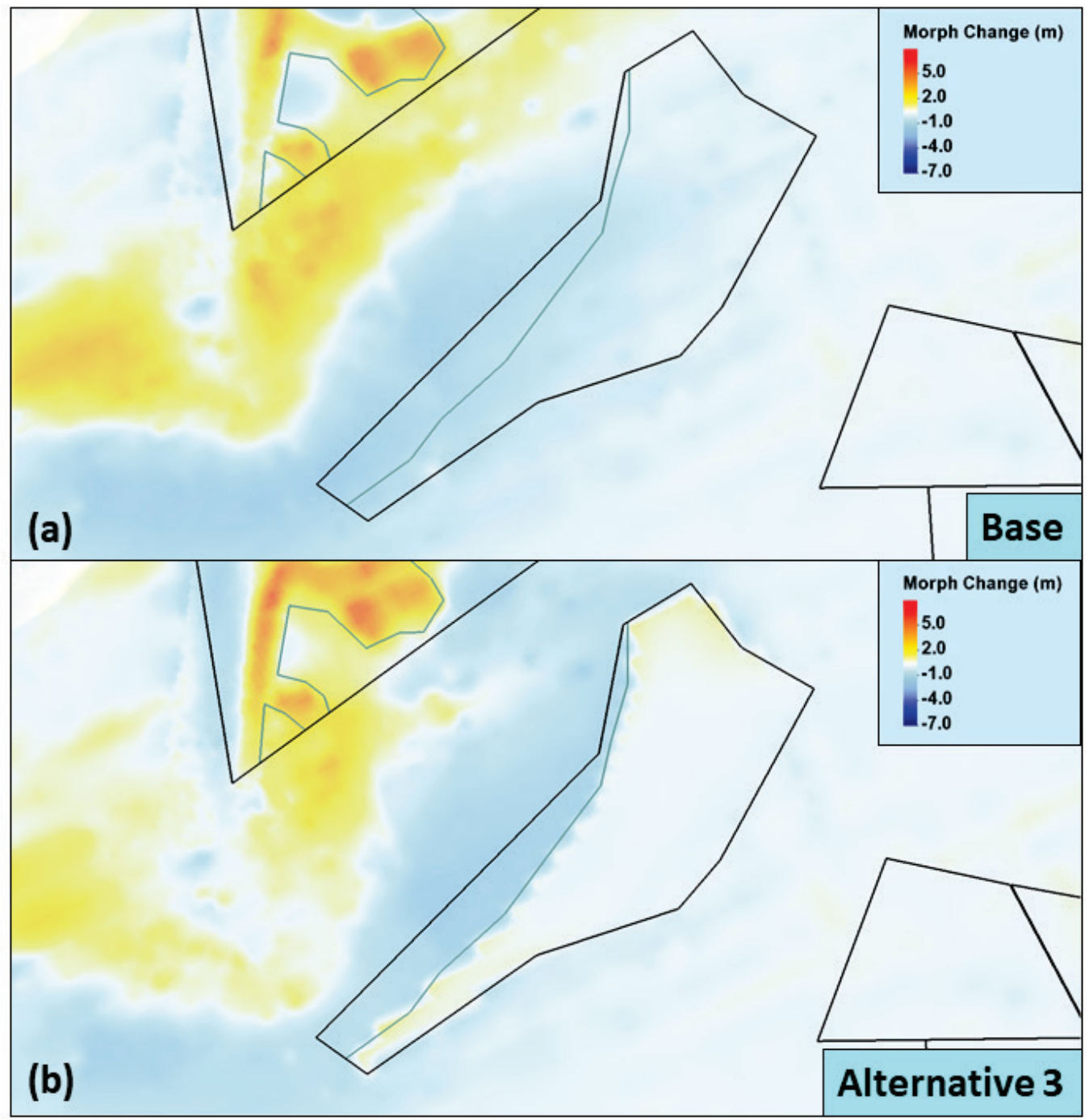


Figure 4-56. Comparison of morphology changes between (a) base case and (b) Alternative 4 within the Stono Ebb Shoal 2 borrow area in 2018. Warmer colors represent sediment accretion and cooler colors sediment erosion.

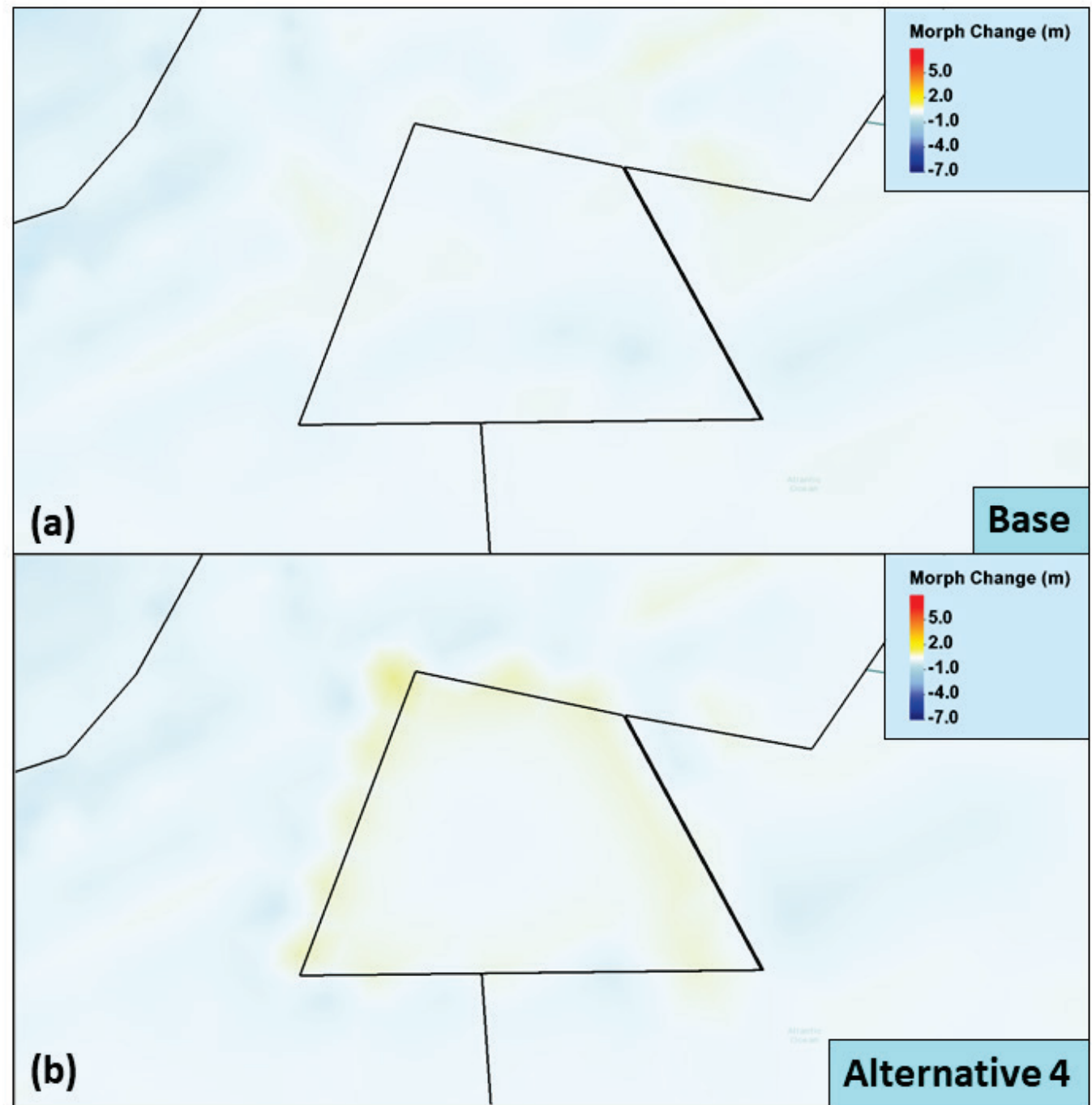


Figure 4-57. Comparison of morphology changes between (a) base case and (b) Alternative 5 within the Stono Inlet borrow area in 2018. Warmer colors represent sediment accretion and cooler colors sediment erosion.

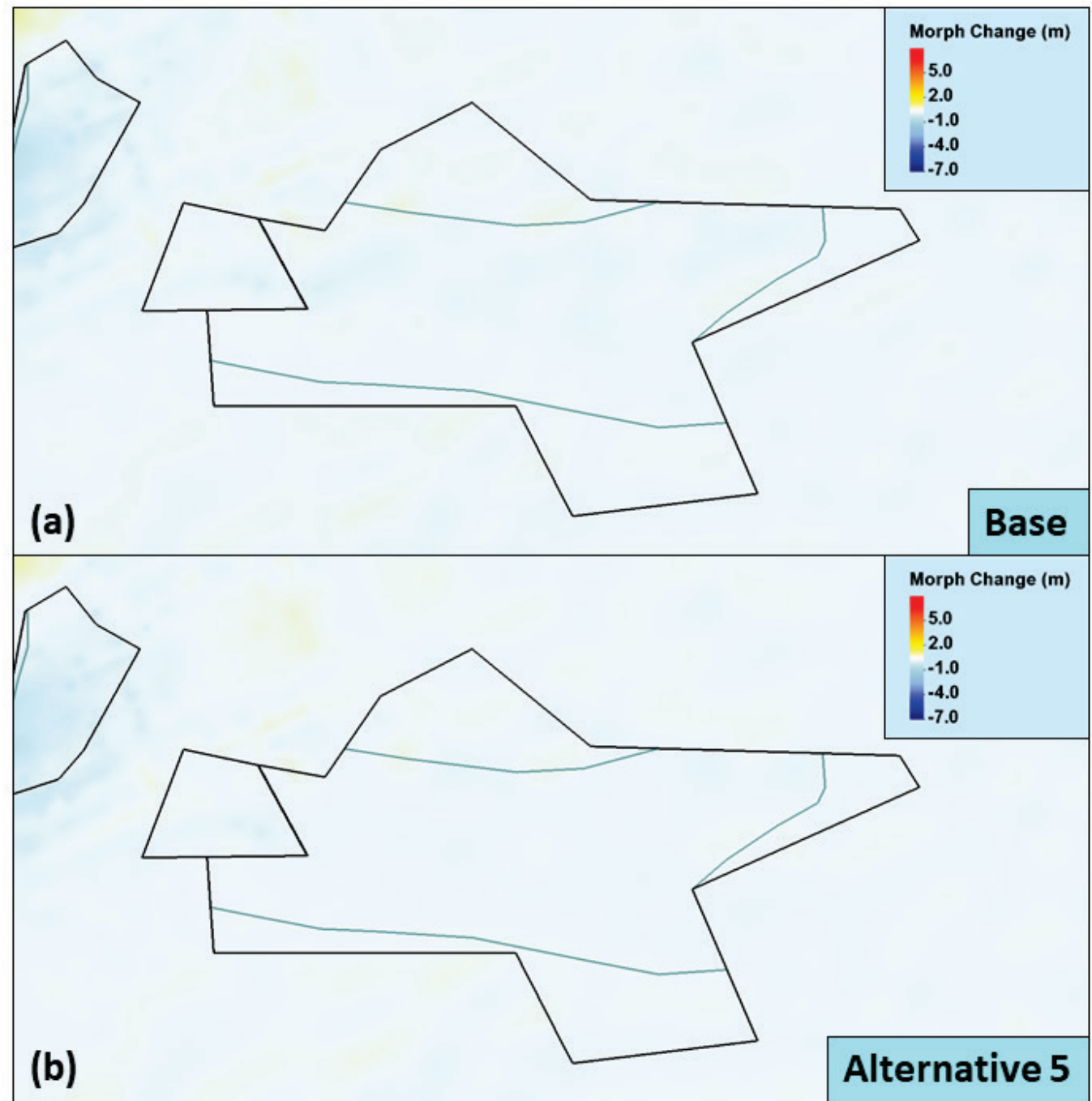

Table 4-12. Comparisons of depth changes between the base case (before sand dredge) and alternatives (after sand dredge) in borrow areas in 2018.

\begin{tabular}{|l|l|l|l|l|l|l|l|l|l|l|l|l|}
\hline & \multicolumn{2}{|l|}{} & \multicolumn{2}{l|}{$\begin{array}{l}\text { Stono Inlet } \\
\text { Borrow Area }\end{array}$} & \multicolumn{2}{l|}{$\begin{array}{l}\text { Stono Ebb } \\
\text { Shoal 1 }(\mathrm{J})\end{array}$} & \multicolumn{2}{l|}{$\begin{array}{l}\text { Stono Ebb } \\
\text { Shoal 2 (K) }\end{array}$} & \multicolumn{2}{l|}{ Stono Inlet (E) } \\
\hline Scenario & Base & Alt 1 & Base & Alt 2 & Base & Alt 3 & Base & Alt 4 & Base & Alt 5 \\
\hline Erosion $(-)(\mathrm{m})$ & -3.2 & -5.1 & -5.0 & -5.8 & -1.9 & -2.1 & -0.4 & -0.4 & -0.4 & -0.2 \\
\hline Deposition $(+)(\mathrm{m})$ & 3.3 & 6.8 & 6.2 & 7.1 & 0.1 & 0.9 & 0.1 & 0.3 & 0.3 & 0.2 \\
\hline
\end{tabular}


The base case in the Folly River borrow area shows that sediment erosion and deposition occurred primarily in the southwest portion of the area, where water was shallow, and sediment was carried and moved by strong flows turning around southwest tip of Folly Island. The alternative case in the actual dredged area shows large deposition at the edge of the borrow area and no significant erosion inside the borrow area because of the decrease of currents due to sand removal (Figure 4-53). For the base case, the maximum erosion and deposition are up to $3.0 \mathrm{~m}(9.84 \mathrm{ft})$, and for the alternative case, can be more than $5.0 \mathrm{~m}(16.41 \mathrm{ft})$ (Table 4-12). In the central and northern portion of the borrow area, sand movement is insignificant, and annual maximum erosion and deposition is less than $0.3 \mathrm{~m}(0.98 \mathrm{ft})$.

For both the base and the alternative cases, the maximum erosion and deposition occurred in the undredged shoaling and the east part of the Stono Inlet Throat borrow area. In the dredged portion, although relatively small, comparable amount of sand was also moved around in the area. For the alternative case in the actual dredged area, sediment deposition was increased significantly (Figure 4-54 and Table 4-12). The maximum deposition is larger than $5.0 \mathrm{~m}$, and the maximum erosion is approximately $2.8 \mathrm{~m}$ (9.19ft).

Next to the shoaling area, the Stono Ebb Shoal 1 borrow area shows dominant erosional trend for both the base and the alternative cases (Figure 4-55). For the alternative case the eroded sand outside the actual dredged area was deposited inside the area. Table 4-12 lists that the maximum erosion in the borrow area is more than $1.0 \mathrm{~m}(3.28 \mathrm{ft})$, but the deposition is only approximately $0.1 \mathrm{~m}(0.33 \mathrm{ft})$ for the base case. For the alternative case, the maximum deposition values are increased to $0.9 \mathrm{~m}$ $(2.95 \mathrm{ft})$, and the maximum erosion decreased to $0.1 \mathrm{~m}(0.33 \mathrm{ft})$ in the dredged area.

Similar to the erosion and deposition pattern in the Stono Ebb Shoal 1 borrow area, the Stono Ebb Shoal 2 borrow area also shows the dominant erosion for the base case and the increased deposition for the dredged case (Figure 4-56). As shown in Table 4-12 the erosion values are approximately $0.4 \mathrm{~m}(1.31 \mathrm{ft})$ for the base case, and the deposition values increased from 0.1 to $0.34 \mathrm{~m}$ ( 0.33 to $1.12 \mathrm{ft}$ ). 
Located in a deep offshore area, the currents in the Stono Inlet borrow area are weak, and slight morphology changes are observed in Figure 4-57. As shown in Table 4-12, the maximum erosion in the area is approximately $0.37 \mathrm{~m}(1,21 \mathrm{ft})$ and the maximum deposition is approximately $0.25 \mathrm{~m}$ $(0.82 \mathrm{ft})$ for the base case. Both the erosion and deposition values are a little smaller for the alternative case.

For the 2018 simulation, the four longshore erosion and deposition zones along Folly Beach as indicated in Figure 4-24 show erosion in Figure 4-58. The average depths, depth changes, and volume changes during the year are listed in Table 4-13. Erosion Zone 1 extends along the shoreline all the way from the southwest to the northeast and is located in the nearshore area of Folly Island. This erosion zone has an average water depth change of $0.93 \mathrm{~m}(3.05 \mathrm{ft})$ and sand loss of 412,270 cu yd $(314,710 \mathrm{~m} 3)$. Through the year, Erosion Zone 2 at the southwest end of Folly Beach experiences a volume loss of 61,289 cu yd $(46,785 \mathrm{~m} 3)$. Between these two zones is the original Deposition Zone 2, now the Erosion Zone 4 which shows an average depth change of $0.1 \mathrm{~m}(0.33 \mathrm{ft})$, and a total sand loss of 10,202 cu yd $\left(7,788 \mathrm{~m}^{3}\right)$. Erosion Zone 3 is the original Deposition Zone 1 and extends from the north end of Erosion Zone 4 to the northeast of Folly Beach. The average depth change within this zone is close to $0.1 \mathrm{~m}$ ( $0.33 \mathrm{ft})$, and the loss of sand materials is $24,252 \mathrm{cu}$ yd $\left(18,513 \mathrm{~m}^{3}\right)$.

Figure 4-58. Morphology changes for the base case nearshore in front of Folly Beach in 2018. Warmer colors represent sediment accretion (delineated by red lines) and cooler colors sediment erosion (delineated by blue lines).

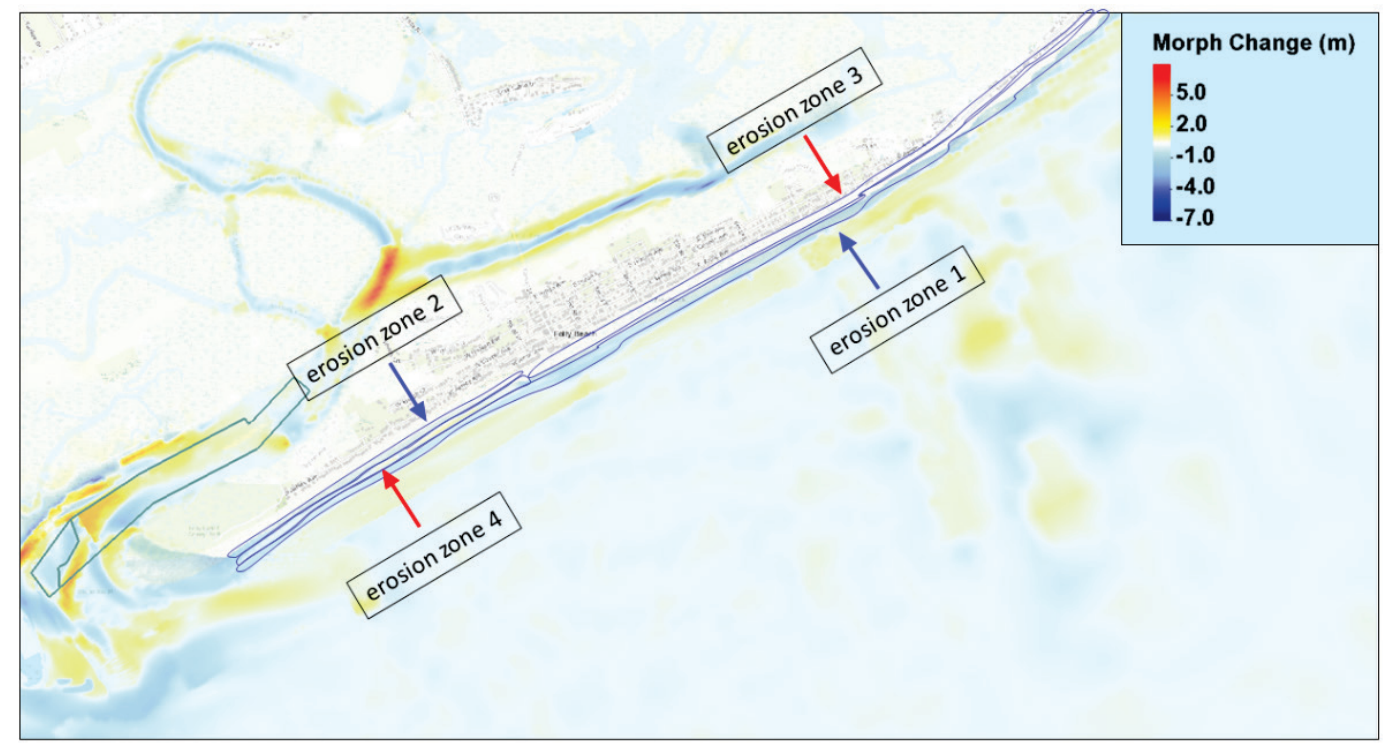


Table 4-13. Longshore erosion and deposition zones in front of Folly Beach during 2018. Positive depths are the land elevation above MSL.

\begin{tabular}{|l|l|l|l|l|}
\hline Variables & $\begin{array}{l}\text { Erosion } \\
\text { Zone 1 }\end{array}$ & $\begin{array}{l}\text { Erosion } \\
\text { Zone 2 }\end{array}$ & $\begin{array}{l}\text { Erosion } \\
\text { Zone 3 }\end{array}$ & $\begin{array}{l}\text { Erosion } \\
\text { Zone 4 }\end{array}$ \\
\hline Average Depth Change $(\mathrm{m})$ & 0.93 & 0.62 & 0.09 & 0.10 \\
\hline Average Depth $(\mathrm{m})$ & -0.89 & 0.01 & 2.4 & -1.43 \\
\hline Volume Change (cu yd) & 412270 & 61289 & 24252 & 10202 \\
\hline
\end{tabular}

Following the above analysis of sediment transport and morphology change, annual volume changes and sediment budget are examined in the borrow areas and nearshore Folly Beach area. Table 4-14 lists the comparisons of bed volume changes between the base and alternative cases in the designated and actual borrow areas in 2018.

Table 4-14. Comparisons of bed volume changes (cubic yard) between the base case (before sand dredge) and alternatives (after sand dredge) in designated and actual borrow areas in 2018. The negative sign indicates the volume loss and the positive the volume gain.

\begin{tabular}{|c|c|c|c|c|c|c|c|c|c|c|}
\hline \multirow{2}{*}{\begin{tabular}{|l} 
Borrow Area \\
Scenario
\end{tabular}} & \multicolumn{2}{|c|}{ Folly River } & \multicolumn{2}{|c|}{ Stono Inlet Throat (I) } & \multicolumn{2}{|c|}{ Stono Ebb Shoal $1(J)$} & \multicolumn{2}{|c|}{$\begin{array}{l}\text { Stono Ebb Shoal } \\
2(\mathrm{~K})\end{array}$} & \multicolumn{2}{|c|}{ Stono Inlet (E) } \\
\hline & Base & Alt 1 & Base & Alt 2 & Base & Alt 3 & Base & Alt 4 & Base & Alt 5 \\
\hline $\begin{array}{l}\text { Designated } \\
\text { Area }\end{array}$ & 214946 & 474928 & 1089153 & 849114 & -2016446 & -965885 & -32588 & 146972 & -162294 & 141382 \\
\hline Actual Area & 289642 & 645420 & 791135 & 2378339 & -1150373 & 46760 & -32588 & 146972 & -259798 & 209950 \\
\hline
\end{tabular}

In the Folly River borrow area, the net sediment accretion occurred both for the base and the alternative cases. Comparing with the base case, the amount of accretion for the alternative case was more than doubled in the designated and the actual dredged areas, respectively. Comparing with the designated area, the amount of accretion in the actual dredged area increases by $35 \%$ and $36 \%$ for the base and the alternative cases, respectively (Table 4-14). The general trend of sediment accretion for different scenarios in different dredge areas indicates that (1) the Folly River borrow area is a sand trap zone, (2) sand removal in the borrow area results in more sediment infilling, and (3) more erosion occurs in the undredged portion of the borrow area.

The erosion and deposition values in Table 4-14 indicate that the Stono Inlet Throat borrow area is also located in a sand trap zone and has the largest sand accumulation among the other areas. Comparing with the 
base case, the accretion for the alternative case decreases by $22 \%$ in the designated dredged area and increases by a factor of three in the actual dredged areas. Comparing with the designated area, the amount of accretion in the actual dredged area is smaller for the base case and much larger for the alternative cases. Considering the much smaller actual dredged area within the designated area, the sediment accretion in this area is significant.

The Stono Ebb Shoal 1 borrow area is also partially dredged. Table 4-14 shows that net erosion occurs in the designated and actual dredged area, but smaller erosion and net accretion occur for the alternative case in the designated and actual dredged areas, respectively. Also, comparing with the base case, the alternative case changes the net erosion trend to the net accretion trend in the actual dredged area. Those values indicate that, associated with sand removal, large erosion happened in the undredged portion of the borrow area and a large amount of eroded materials moved into the actual dredged area. The trend of volume changes in this area is consistent with morphology change as shown in Figure 4-54.

The Stono Ebb Shoal 2 borrow area has the same designated and actual dredged area. Sand dredge changes the erosion and deposition pattern from erosion to deposition for the area. A large amount of material was removed from neighboring areas and deposited in the borrow area (Table 4-14).

In the designated Stono Inlet borrow area, Table 4-14 shows net erosion for the base case and the alternative case. The amount of erosion for the alternative case is much smaller than that for the base case, meaning that sand removal still causes new deposition in this borrow area.

For the 2018 results, nearshore sediment budget and bed volume changes are analyzed around the polygons shown in Figure 4-30. Based on the total sediment transport across each polygon line, the transport directions are drawn, and sediment balance for each polygon is indicated by a positive (volume gain) or negative (volume loss) sign in Figure 4-59. Similar to the results by the hurricane impact, the 2018 results also show persistent longshore transport direction from the northeast to the southwest over all the polygon areas. Cross-shore transport direction is varying. The pattern of the net sand gain or loss within each polygon area is also the same as that from the storm simulation. 
Figure 4-59. The calculated total sediment transport directions across polygon lines. The positive sign indicates bed volume gain and the negative the volume loss within the corresponding polygon area.

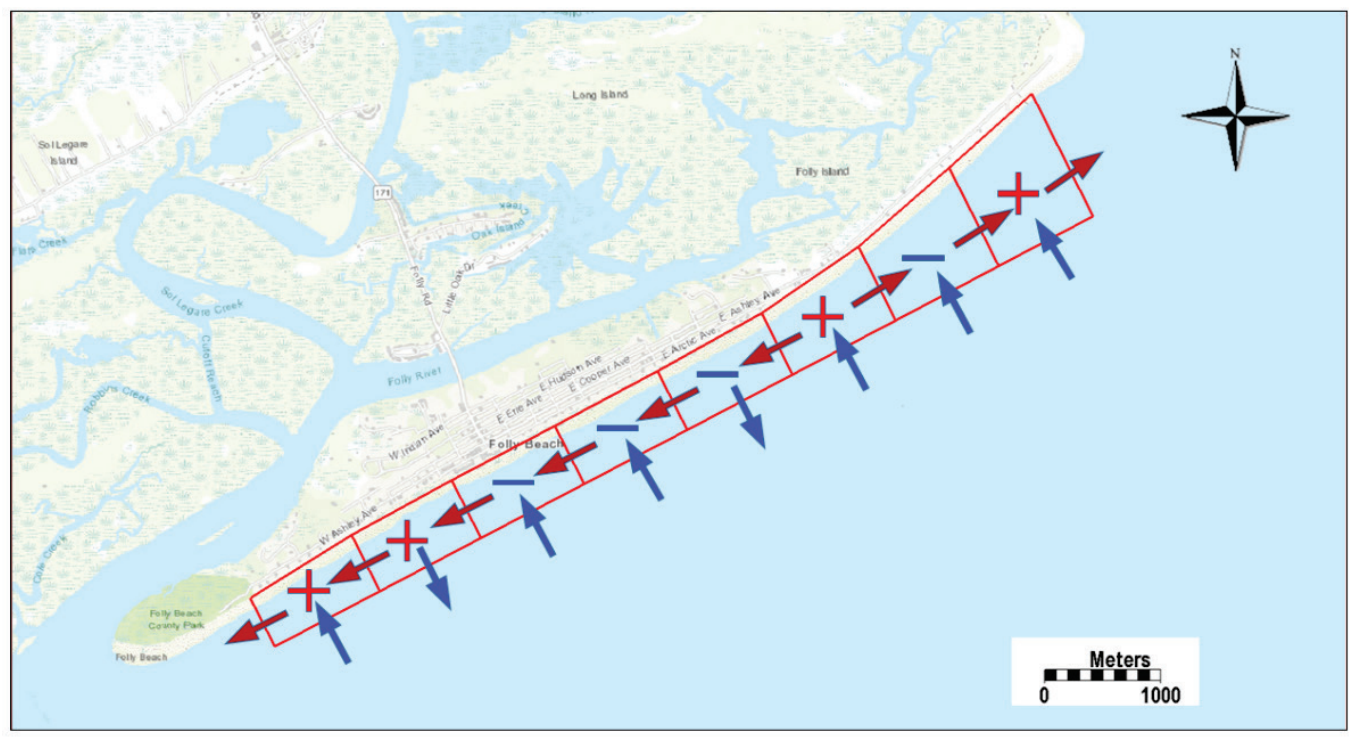

Based on the morphology changes, volume changes within each polygon are estimated and values are listed in Table 4-15.

Table 4-15. Bed volume changes (cubic yard) for the base case (before sand dredge) and alternatives (after sand dredge) in polygon areas as shown in Figure 4-30 in 2018. The negative sign indicates the volume loss and the positive the volume gain.

\begin{tabular}{|l|l|l|l|l|l|l|}
\hline \multirow{2}{*}{ Area } & \multicolumn{7}{|c|}{ Alternative } \\
\cline { 2 - 7 } & Base & 1 & 2 & 3 & 4 & 5 \\
\hline P1 & -698 & 371 & -493 & -981 & 3044 & -67 \\
\hline P2 & 12839 & 11847 & 13369 & 13131 & 11665 & 12364 \\
\hline P3 & -65094 & -64626 & -65835 & -65657 & -62027 & -65742 \\
\hline P4 & -20576 & -20959 & -22014 & -19710 & -23561 & -23078 \\
\hline P5 & -27724 & -27285 & -28037 & -26171 & -24151 & -26118 \\
\hline P6 & 6251 & 9217 & 3741 & 6675 & 14721 & 2263 \\
\hline P7 & -23636 & -23714 & -14277 & -27624 & -20836 & -31210 \\
\hline P8 & 19493 & 20376 & 19442 & 16460 & 23498 & 19120 \\
\hline
\end{tabular}


For the base case, the net sediment loss in the southwest and the central sections of Folly Beach (P1 to $\mathrm{P}_{5}$ ) is approximately 101,253 cu yd $\left(77,292 \mathrm{~m}^{3}\right)$ in 2018. The northeast section of the beach (P6 to P8) shows small amount of sand gain of $2,108 \mathrm{cu}$ yd $\left(1,609 \mathrm{~m}^{3}\right)$. For the alternatives, the trend of the volume gain or loss within each polygon area is similar to the base case.

Corresponding to the changes in flow and sediment transport patterns related to the base and alternative cases, volume changes around Bird Key Island and Kiawah Island are examined for the 2018 simulation. The calculated results within the specified areas (Figure 4-32) are shown in Table 4-16.

Table 4-16. Bed volume changes (cubic yard) for the base case (before sand dredge) and alternatives 1, 2, and 3 (after sand dredge) in polygon areas around Bird Key Island and Kiawah Island in 2018. The negative sign indicates the volume loss and the positive the volume gain.

\begin{tabular}{|c|c|c|c|c|c|}
\hline \multirow{2}{*}{\multicolumn{2}{|c|}{ Area }} & \multicolumn{4}{|c|}{ Alternative } \\
\hline & & Base & 1 & 2 & 3 \\
\hline \multicolumn{2}{|c|}{ Bird Key Island } & -100494 & $\mid-99119$ & -98526 & -101646 \\
\hline \multirow{3}{*}{$\begin{array}{l}\text { Kiawah } \\
\text { Island }\end{array}$} & East & -622754 & -583562 & -565354 & -574211 \\
\hline & SE & -283691 & -327545 & -313469 & -319679 \\
\hline & South & -28076 & -17436 & -12695 & -4981 \\
\hline
\end{tabular}

Similar to the hurricane impact all the base and alternative cases show material loss around Bird Key Island and Kiawah Island. Within the polygon area surrounding Bird Key Island, the sediment volume changes due to the three alternatives are less than $2 \%$.

The volume changes within three polygon areas along the shoreline of Kiawah Island show different responses to the dredges in the three borrow areas. The polygon area on the east side of the island shows the largest sediment loss during this $1 \mathrm{yr}$ simulation. The three alternatives reduce the sediment loss by $6 \%-9 \%$ within the area. On the southeast side of the island, the sediment loss is approximately $300,000 \mathrm{cu}$ yd $\left(229,000 \mathrm{~m}^{3}\right)$. Comparing with the base case, the alternatives promote the sediment loss by more than $10 \%$ within this area. The alternatives also reduce the sediment loss within the polygon on the south side of the island, but the total volume changes are insignificant comparing with the changes within the other two areas. 


\section{Conclusions}

With the implementation of a field survey program, a coupled wave, hydrodynamic, sediment transport model, the CMS, was developed and applied to investigate sediment transport and morphology changes around the Stono Inlet estuarine system and adjacent Folly Beach, South Carolina. Field data collection included the deployment of two AWACs to measure waves, water level, and current within the Stono River channel and the open water in nearshore Folly Beach area. Driven by tide, waves, and wind, the CMS simulations include a 40-day calibration and validation, an 8-day storm simulation (Hurricane Hugo, 1989), and a 1 yr simulation (2018). For the storm and 2018 simulations, the base case and five alternative cases were configured, in which sand materials were dredged from the designated borrow areas and placed on Folly Beach for beach protection. By comparing the base case with each of the alternative cases, the model results were evaluated for sediment movement around the sand borrow and nearshore areas. From this modeling application, the major conclusions are drawn as follows:

1. Field data program is an integral component to the successful implementation of the numerical model and to the proper validation of the physical forces driving sediment transport in the coastal zone at the Stono Inlet estuarine system. Tidal flushing was captured through spatial and temporal field data collection of water levels and currents at the Stono River channel and the nearshore open ocean. Measured waves and currents provided a strong validation for numerical simulation of sediment transport.

2. The calibration of the CMS provided a close representation of physical forcing factors that drive sediment transport in the nearshore zone at the Stono Inlet system. Primary driving forcing in the areas are tide, wind, and waves. Tidal currents are the dominant flow component in the estuary and around the inlet, and storm-/wave-driven currents are dominant in the open ocean area.

3. Among five sand borrow areas, relatively large backfilling occurs in nearshore areas, the Folly River and the Stono Inlet Throat areas. In offshore areas, sand removal does not have significant impact on sediment transport fields due to weak currents. Comparing the base case with each of the alternative cases, sand dredged in a borrow area always induces more material accumulation. 
4. Dredging a borrow area creates large depth gradients between dredged and undredged parts of the ocean, which tends to cause large current changes and more sediment deposition. Based on the model results, sediment supplies to the Folly River borrow area mainly come from the nearshore Folly Beach area, which are carried by the longshore current turning around the southwest tip of Folly Island. The actual dredged portion in the Stono Inlet Throat borrow area receives large amount of sediment from neighboring undredged shallow area.

5. In the nearshore Folly Beach area, model results show dominant longshore current and sediment transport directions from the northeast to the southwest. The net sand loss occurs in the southwest and the central sections and the net sand loss in the northeast section of Folly Island.

6. The Hurricane Hugo and the 2018 simulations show similar trend in morphology and volume changes, and erosion and deposition patterns around the sand borrow areas and in the nearshore Folly Beach area.

7. Both the base and the alternative cases of the Hurricane Hugo and the 2018 simulations indicate net sediment losses in the specified areas around Bird Key Island and Kiawah Island. During Hurricane Hugo dredging in the Folly River borrow area causes the largest sediment volume change, reducing the sediment loss by more than $10 \%$, around Bird Key Island. Comparing the alternative with the base cases, the 2018 simulation shows significant increase and decrease of sediment loss on the southeast and the east side of Kiawah Island, respectively. 


\section{References}

Aquaveo. 2020. Surface-water Modeling System (SMS), version 13.0, http://www.aquaveo.com/software/sms-surface-water modeling-system.

Lin, L., Z. Demirbilek, and F. Yamada. 2008. CMS-Wave: A Nearshore Spectral Wave Processes Model for Coastal Inlets and Navigation Projects. ERDC/CHL TR-o813. Vicksburg, MS: US Army Engineer Research and Development Center.

NDBC (National Data Buoy Center). 2020. National Data Buoy Center, National Oceanographic and Atmospheric Administration. 30 September 2020. http://ndbc.noaa.gov/.

NOAA (National Oceanic and Atmospheric Administration). 2020. Tides and Currents. National Oceanographic and Atmospheric Administration. Accessed 30 September 2020. http://tidesandcurrents.noaa.gov/.

NOAA NCEI (NOAA National Centers for Environmental Information). 2020. Continuously Updated Digital Elevation Model (CUDEM) - 1/9 Arc-Second Resolution Bathymetric - Topographic Tiles. Accessed 8 October 2020. https://doi.org/10.25921/ds9v-ky35.

NOAA NGS (NOAA National Geodetic Survey). 2011. NOAA Shoreline Website. "Continually Updated Shoreline Product (CUSP)." https://shoreline.noaa.gov/data/datasheets/cusp.html.

Sanchez, A., W. Wu, T. M. Beck, H. Li, J. Rosati III, R. Thomas, J. D. Rosati, Z. Demirbilek, M. Brown, and C. Reed. 2011a. Verification and Validation of the Coastal Modeling System, Report 3: Hydrodynamics. ERDC/CHL TR-11-10. Vicksburg, MS: US Army Engineer Research and Development Center.

Sanchez, A., W. Wu, T. M. Beck, H. Li, J. D. Rosati, Z. Demirbilek, and M. Brown. 2011b. Verification and Validation of the Coastal Modeling System, Report 4: Sediment Transport and Morphology Change. ERDC/CHL TR-11-10. Vicksburg, MS: US Army Engineer Research and Development Center.

Wu, W., A. Sanchez, and M. Zheng. 2011. "An Implicit 2-D Shallow Water Flow Model on Unstructured Quadtree Rectangular Mesh.” Journal of Coastal Research Special Issue 59: 15-26. 


\section{Acronyms and Abbreviations}

$\begin{array}{ll}\text { AWAC } & \text { Acoustic wave and current profiler } \\ \text { CMS } & \text { Coastal Modeling System } \\ \text { CRM } & \text { Coastal Relief Model } \\ \text { DEM } & \text { Digital Elevation Model } \\ \text { MSL } & \text { Mean Sea Level } \\ \text { NDBC } & \text { National Data Buoy Center } \\ \text { NOAA } & \text { National Oceanic and Atmospheric Administration } \\ \text { NRMSE } & \text { Normalized Root-Mean-Square } \\ \text { RMSE } & \text { Root-Mean-Square Error } \\ \text { SAC } & \text { Charleston District } \\ \text { SMS } & \text { Surface-water Modeling System } \\ \text { USACE } & \text { US Army Corps of Engineers } \\ \text { WIS } & \text { Wave Information Studies } \\ \text { WSE } & \text { Water surface elevation }\end{array}$




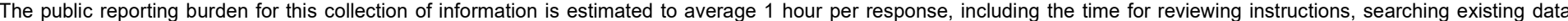

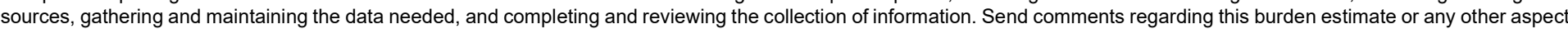

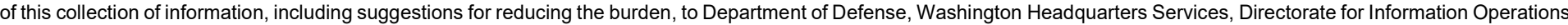

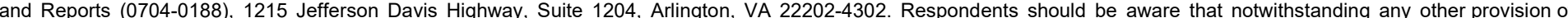
law, no person shall be subject to any penalty for failing to comply with a collection of information if it does not display a currently valid OMB control number. PLEASE DO NOT RETURN YOUR FORM TO THE ABOVE ADDRESS.

\begin{tabular}{l|l|l}
\hline $\begin{array}{l}\text { 1. REPORT DATE } \\
\text { November } 2021\end{array}$ & $\begin{array}{l}\text { 2. REPORT TYPE } \\
\text { Final Report }\end{array}$ & 3. DATES COVERED (FrOm - To)
\end{tabular}

\section{TITLE AND SUBTITLE}

Sediment Transport Modeling at Stono Inlet and Adjacent Beaches, South Carolina 5a. CONTRACT NUMBER

5b. GRANT NUMBER

5c. PROGRAM ELEMENT NUMBER

5d. PROJECT NUMBER

5e. TASK NUMBER

5f. WORK UNIT NUMBER

8. PERFORMING ORGANIZATION REPORT NUMBER Wilmington District 69 Darlington Ave Wilmington, NC 28403

ERDC/CHL TR-21-19

US Army Engineer Research and

Development Center

3909 Halls Ferry Road

Vicksburg, MS 39180-6199

\section{SPONSORING/MONITORING AGENCY NAME(S) AND ADDRESS(ES)}

US Army Engineer District, Wilmington

10. SPONSOR/MONITOR'S ACRONYM(S)

Wilmington, NC 28403

\section{SPONSOR/MONITOR'S} REPORT NUMBER(S)

\section{DISTRIBUTION/AVAILABILITY STATEMENT}

Approved for public release; distribution is unlimited.

\section{SUPPLEMENTARY NOTES}

MIPR W81L892470179

\section{ABSTRACT}

This report documents a numerical modeling investigation for dredged material from nearshore borrow areas and placed on Folly Beach adjacent to Stono Inlet, South Carolina. Historical and newly collected wave and hydrodynamic data around the inlet were assembled and analyzed. The datasets were used to calibrate and validate a coastal wave, hydrodynamic and sediment transport model, the Coastal Modeling System. Sediment transport and morphology changes within and around the immediate vicinity of the Stono Inlet estuarine system, including sand borrow areas and nearshore Folly Beach area, were evaluated. Results of model simulations show that sand removal in the borrow areas increases material backfilling, which is more significant in the nearshore than the offshore borrow areas. In the nearshore Folly Beach area, the dominant flow and sediment transport directions are from the northeast to the southwest. Net sediment gain occurs in the central and southwest sections while net sediment loss occurs in the northeast section of Folly Island. A storm and a 1-year simulation developed for the study produce a similar pattern of morphology changes, and erosion and deposition around the borrow areas and the nearshore Folly Beach area.

\section{SUBJECT TERMS}

Dredging, Dredging spoil, Folly Beach (S.C.), Hydrodynamics, Sedimentation and deposition, Sediment transport, Stono Inlet (S.C.)

\section{SECURITY CLASSIFICATION OF:}

\begin{tabular}{|l|l|l|}
\hline \multicolumn{1}{|l|}{ 16. SECURITY CLASSIFICATION OF: } \\
\hline a. REPORT & b. ABSTRACT & c. THIS PAGE \\
Unclassified & Unclassified & Unclassified \\
\hline
\end{tabular}

17. LIMITATION OF ABSTRACT

SAR
18. NUMBER

OF PAGES

114 19a. NAME OF RESPONSIBLE PERSON Honghai Li

19b. TELEPHONE NUMBER (Include area code) 601-634-2840 